\author{
UNIVERSIDADE DE SÃO PAULO \\ ESCOLA DE COMUNICAÇÕES E ARTES \\ PROGRAMA DE PÓS-GRADUAÇÃO EM MÚSICA
}

MARTA MACEDO BRIETZKE

MÚSICA CONTEMPORÂNEA NA INICIAÇÃO COLETIVA AO VIOLONCELO: UMA PESQUISA-AÇÃO COM JOGOS DE IMPROVISAÇÃO EM TRÊS INSTITUIÇÕES DE ENSINO NO ESTADO DE SÃO PAULO 


\title{
MÚSICA CONTEMPORÂNEA NA INICIAÇÃO COLETIVA AO VIOLONCELO: UMA PESQUISA-AÇÃO COM JOGOS DE IMPROVISAÇÃO EM TRÊS INSTITUIÇÕES DE ENSINO NO ESTADO DE SÃO PAULO
}

\section{Versão corrigida}

(A versão original encontra-se na Biblioteca da Escola de Comunicações e Artes e na Biblioteca Digital de Teses e Dissertações da USP)

\begin{abstract}
Dissertação apresentada ao Programa de PósGraduação em Música da Escola de Comunicações e Artes da Universidade do Estado de São Paulo, na área de concentração Processos de Criação Musical, linha de pesquisa Música e educação: processos de criação, ensino e aprendizagem, como requisito parcial para a obtenção do título de Mestre em Música.

Orientador: Prof. Dr. Fábio Soren Presgrave Coorientador: Prof. Dr. Mário André Wanderley Oliveira
\end{abstract}


Autorizo a reprodução e divulgação total ou parcial deste trabalho, por qualquer meio convencional ou eletrônico, para fins de estudo e pesquisa, desde que citada a fonte.

Catalogação na Publicação

Serviço de Biblioteca e Documentação

Escola de Comunicações e Artes da Universidade de São Paulo

Dados inseridos pelo(a) autor(a)

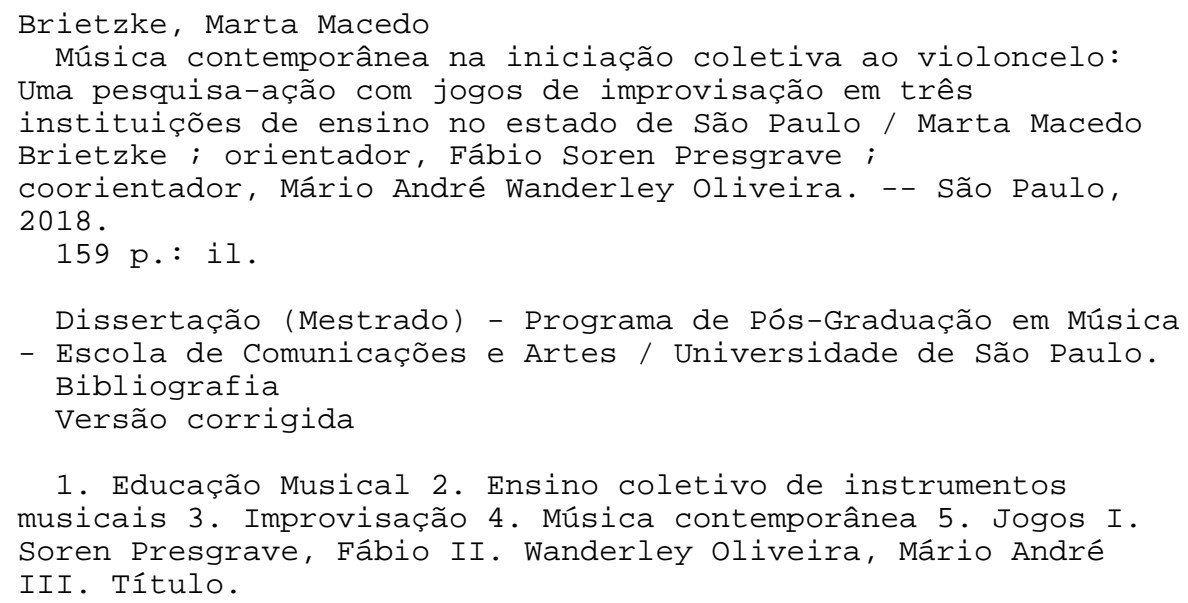

CDD 21.ed. - 780 
Nome: BRIETZKE, Marta Macedo.

Título: Música contemporânea na iniciação coletiva ao violoncelo: uma pesquisa-ação com jogos de improvisação em três instituições de ensino no estado de São Paulo.

Dissertação apresentada à Escola de Comunicações e Artes da Universidade do Estado de São Paulo, na área de concentração Processos de Criação Musical, linha de pesquisa Música e educação: processos de criação, ensino e aprendizagem como requisito para a obtenção do título de Mestre em Música.

Aprovada em: 12/12/2018

BANCA EXAMINADORA:

\author{
Prof. Dr. Fabio Soren Presgrave \\ Instituição: USP \\ Membro da Banca
}

Prof. Dr. Teresa Cristina Rodrigues Silva

Instituição: IFPB

Membro da Banca

Prof. Dr. Carlos Elias Kater

Instituição:

Membro da Banca 


\section{AGRADECIMENTOS}

Agradeço a minha família, especialmente aos meu pais, Eduardo Henrique de Mattos Brietzke e Maria Teresa Macedo Brietzke (in memorian), e a minha irmã, Elisa Macedo Brietzke, por sempre acompanharem e expressarem total apoio às minhas atividades musicais e acadêmicas.

Agradeço aos meus orientadores, ao Professor Doutor Fabio Soren Presgrave e ao Professor Doutor Mário André Wanderley Oliveira pelos momentos de convivência e pelas importantes observações, apontamentos, considerações e contribuições em todas as fases desta pesquisa.

Agradeço aos meus alunos e aos alunos que gentilmente participaram desta pesquisa, de maneira entusiástica e colaborativa, aderindo às propostas do trabalho de forma crítica e responsável.

Agradeço também aos familiares dos alunos envolvidos na pesquisa e aos professores, diretores e coordenadores do Instituto Baccarelli, do Projeto Guri-Polo de Indaiatuba e do Instituto Fukuda, que cederam espaço e tempo em suas aulas e instituições para que o trabalho pudesse ser concretizado.

Agradeço aos professores, diretores, funcionários, colegas e à toda comunidade acadêmica da Escola de Comunicações e Artes da Universidade de São Paulo que me receberam calorosamente nesta universidade e me apoiaram durante todo o processo do curso de mestrado.

Por fim, agradeço aos meus amigos de Porto Alegre e de São Paulo, especialmente aos amigos Akinori Hieda e Vanessa Santos Maciel, que me acolheram em São Paulo, tornando-se parte da minha família. Agradeço também ao amigo Renato Borges, pela dedicação nas revisões e pela paciência, amizade e companheirismo. 


\section{RESUMO}

BRIETZKE, Marta Macedo. Música contemporânea na iniciação coletiva ao violoncelo: uma pesquisa-ação com jogos de improvisação em três instituições de ensino no estado de São Paulo. 2018. 159 p. Dissertação (Mestrado). Escola de Comunicações e Artes. Universidade de São Paulo, São Paulo, 2018.

Resumo: Esta dissertação é um estudo sobre o uso de jogos de improvisação na iniciação coletiva ao violoncelo. O objetivo desta pesquisa, realizada no âmbito do Programa de PósGraduação em Música da Escola de Comunicações e Artes da Universidade de São Paulo, foi investigar a implementação de modelos de jogos de improvisação, já empregados em outros grupos de educandos, na iniciação coletiva ao violoncelo, com o intuito de proporcionar a aproximação dos estudantes com as poéticas da música contemporânea. O procedimento metodológico elencado para o trabalho foi a pesquisa-ação, a qual foi realizada em três instituições de ensino do estado de São Paulo: o Instituto Baccarelli, o Projeto Guri-Polo de Indaiatuba e o Instituto Fukuda. Foram utilizados como instrumentos e técnicas de coleta de dados a observação participante, o diário de campo, a aplicação de questionário junto a vinte e quatro estudantes e de entrevistas semiestruturadas junto a quatro professores que participaram das atividades, anotações feitas pelos estudantes após a realização dos encontros e a gravação em vídeo de algumas atividades propostas. A análise dos dados foi estruturada a partir das considerações dos alunos e dos professores participantes, sendo que essas foram abordadas em relação às referências bibliográficas consultadas e à observação das atividades relatadas em diário de campo, com o suporte das gravações em vídeo. Após a análise dos dados, foi possível perceber que, na implementação dos jogos elaborados, baseados a partir das proposições de Delalande (2001), Gainza (2009), Brito (2003, 2011), Freixedas (2015) e Cruz (2017), a maioria dos alunos compreendeu as propostas das atividades como jogo e criação musical. Grande parte dos estudantes relatou que se sentiu confortável ao praticar os jogos de improvisação, reconhecendo a construção de narrativas musicais nas atividades, a possibilidade de maior integração com seus colegas de classe, a compreensão de processos de criação musical e a aproximação com poéticas da música contemporânea. Os professores envolvidos destacaram o desenvolvimento da criatividade e dos processos de aprendizagem coletiva proporcionados pelas atividades, ressaltando, porém, a necessidade de contextualização das propostas dentro de um modelo de ensino tradicional. O trabalho aponta para possíveis desdobramentos para a área da educação musical, configurando-se como uma possibilidade de aplicação de jogos de improvisação na iniciação coletiva de um instrumento musical, bem como possibilitando sua implementação no ensino e aprendizagem de outros instrumentos de cordas friccionadas, além de oferecer subsídios para a configuração de propostas semelhantes direcionadas a outros níveis de aprendizagem ao violoncelo.

Palavras-chave: Jogos de improvisação; Ensino coletivo; Violoncelo; Poéticas da música contemporânea. 


\begin{abstract}
BRIETZKE, Marta Macedo. Contemporary music in the collective initiation to the cello: an action research with improvisation games in three educational institutions in the state of São Paulo. 2018. 159 p. Dissertation (Master). Escola de Comunicações e Artes. Universidade de São Paulo, São Paulo, 2018.
\end{abstract}

\begin{abstract}
This dissertation is a study on the use of improvisation games in group cello lessons. The goal of this research, conducted during the Graduate Music Program at São Paulo University, was to investigate the implementation of improvisation games, already applied in other groups of students, in the collective initiation to the cello, with the purpose of promoting the approximation of students with the poetics of contemporary music. The methodological procedure listed for this work was the research-action, applied in three educational institutions of the state of São Paulo: Instituto Baccarelli, Projeto Guri and Instituto Fukuda. Participant observation, field diary, the application of a questionnaire to twenty-for students and semistructured interviews with the for teachers who participated in the activities, notes written by the students after the activities and the video recording of some the activities were used as instruments and techniques of data collection. The analysis of the data was structured based on the students' and the participating teachers' considerations and this were approached in relation to the consulted bibliographical references and to the observation of the activities reported in the field diary, with the support of video recordings. After analysing the data, it was possible to notice that in the implementation of the games, based on the propositions of Delalande (2001), Gainza (2009), Brito (2003, 2011), Freixedas (2015) e Cruz (2017), most of the students understood most the proposals of the activities such a game and music creation. Most of the students reported that felt comfortable playing improvisational games, recognizing the construction of musical narratives in the activities, the possibility of greater integration with their classmates, the understanding of the processes of music creation and the approach with poetics of contemporary music. The teachers involved highlighted the development of the creativity and group teaching provided by the activities, emphasizing, however, the need to contextualize the proposals within a traditional teaching model. This work indicates possible developments in the area of music education, being configured as a possibility for the application of improvisation games in the group teaching, as well as enabling its implementation in the teaching and learning of other strings instruments, besides providing support for setting up similar proposals aimed at the other levels of celli learning.
\end{abstract}

Keywords: Improvisational games; Group teaching; Cello; Poetics of contemporary music. 


\section{SUMÁRIO}

1 INTRODUÇÃO.

2 MÚSICA CONTEMPORÂNEA E JOGOS DE IMPROVISAÇÃO: POSSIBILIDADES

PARA O ENSINO COLETIVO DE INSTRUMENTO …………………………….............19

2.1 MÚSICA CONTEMPORÂNEA E FORMAÇÃO INSTRUMENTAL ....................19

2.2 A IMPROVISAÇÃO E SEU USO NA EDUCAÇÃO MUSICAL ............................25

2.3 O ENSINO COLETIVO DE INSTRUMENTO ………….......................................

3 BASES TEÓRICO-METODOLÓGICAS DA PESQUISA.................................................

3.1 A ESCOLHA DA ABORDAGEM E DO MÉTODO ……………….......................4

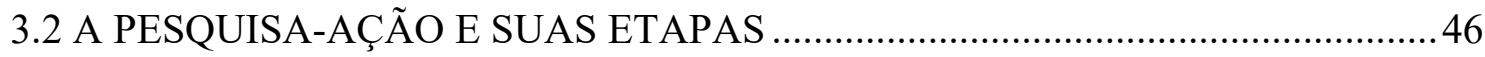

3.3 INSTRUMENTOS E TÉCNICAS DE COLETA DE DADOS ................................51

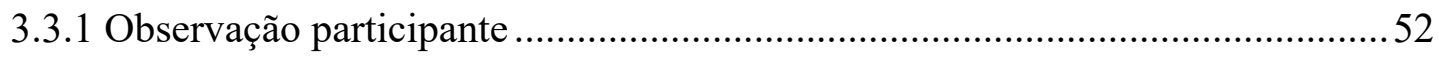

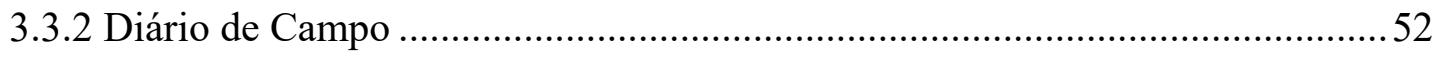

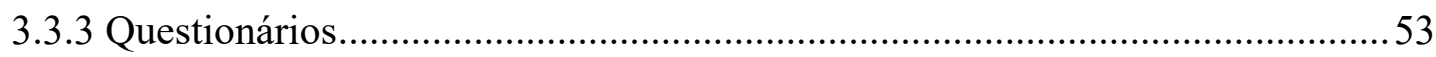

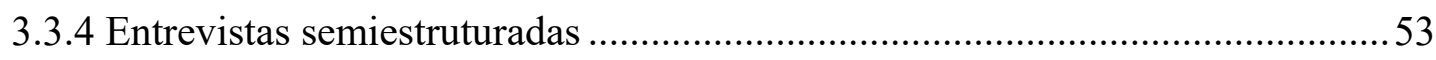

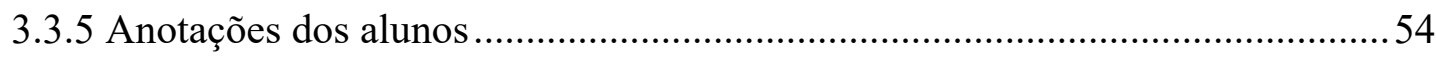

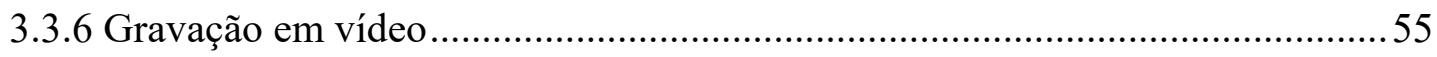

3.4 INSTRUMENTOS E TÉCNICAS DE ORGANIZAÇÃO E ANÁLISE DOS DADOS . .55

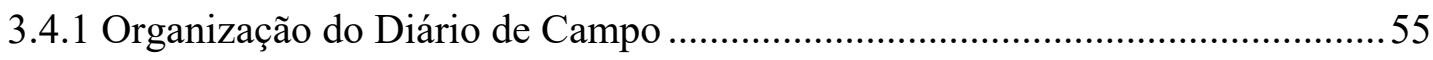

3.4.2 Tabulação dos dados dos questionários .........................................................56

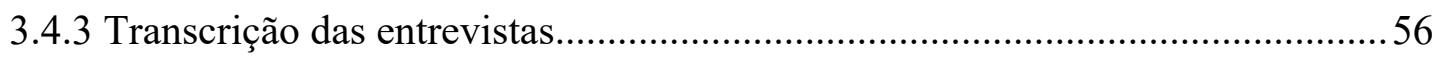

3.4.4 Categorização das anotações feitas pelos alunos ………………………….......56

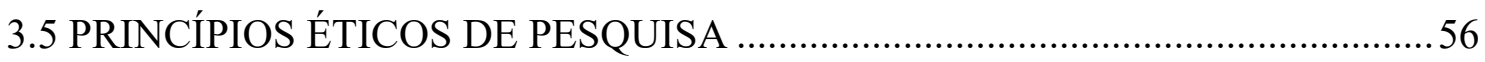

4 CARACTERIZAÇÃO DAS INSTITUIÇÕES, DOS PARTICIPANTES E DAS

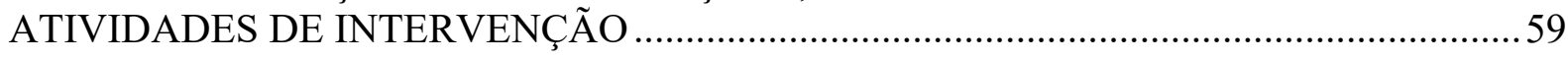

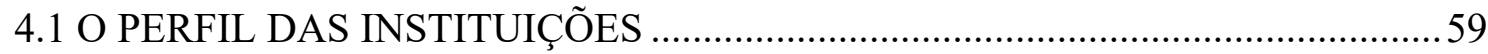

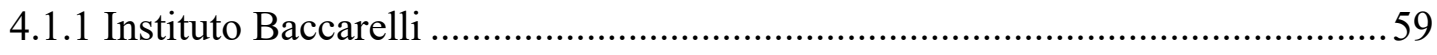

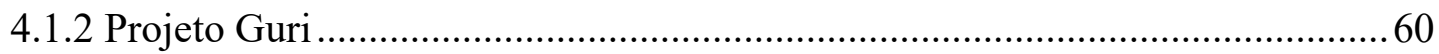

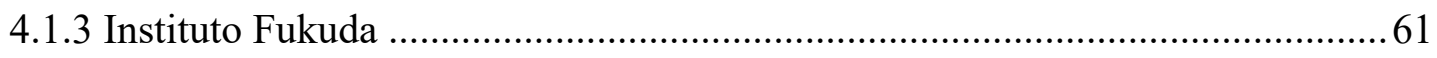

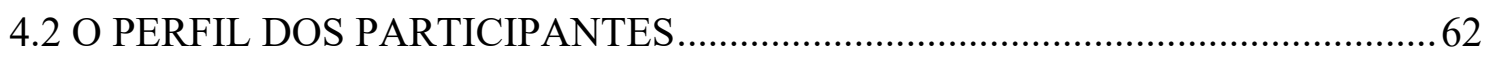

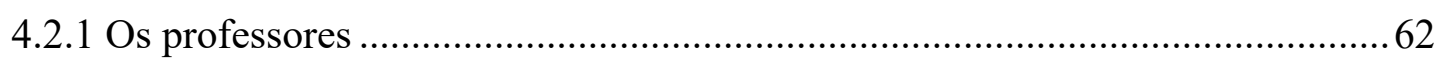

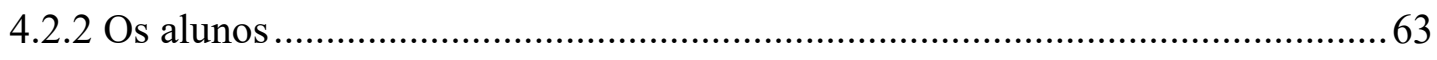

4.3 O PERFIL DA PROPOSTA E SEUS PRESSUPOSTOS TEÓRICOS .......................63

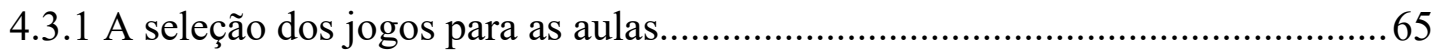

5 A IMPLEMENTAÇÃO E A AVALIAÇÃO DAS ATIVIDADES ………………………....73 
5.1 A IMPLEMENTAÇÃO DOS JOGOS DE IMPROVISAÇÃO ..................................73

5.1.1 Pergunta e Resposta com cordas soltas em pizzicato...........................................73

5.1.2 Sinal Verde X Sinal Vermelho.....................................................................

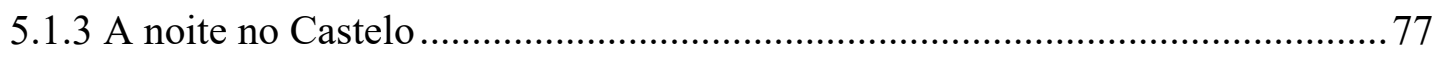

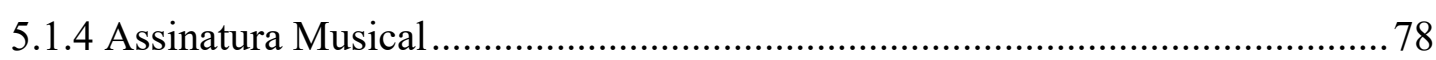

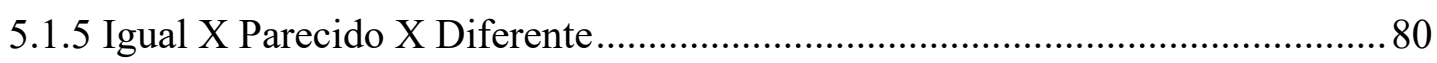

5.1.6 Composição com gravuras e escrita da composição com notação própria ........81

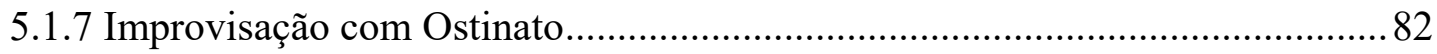

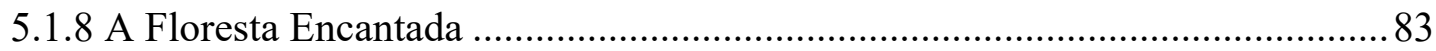

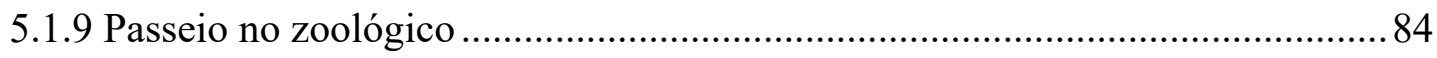

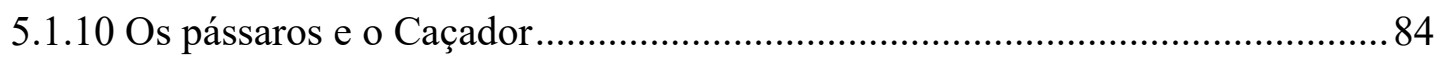

5.2 CONSIDERAÇÕES DOS ESTUDANTES SOBRE AS AULAS …………….........85

5.3 CONSIDERAÇÕES DOS PROFESSORES SOBRE AS AULAS ……………......... 100

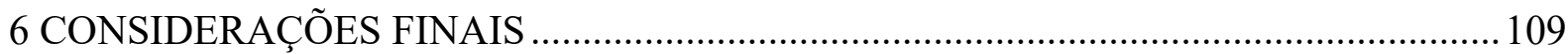

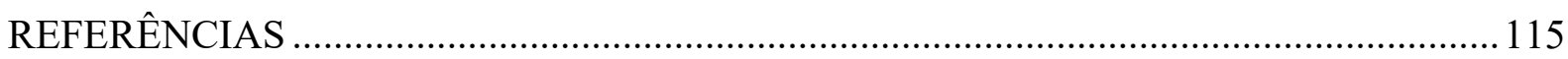

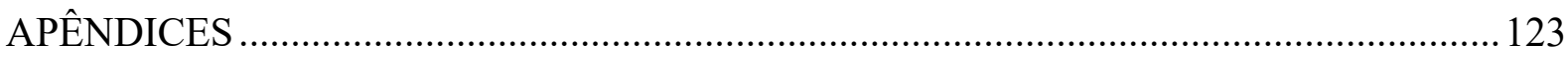

Apêndice A - Jogos propostos ao Instituto Baccarelli ................................................... 123

Apêndice B - Jogos propostos ao Projeto Guri-Polo de Indaiatuba................................. 129

Apêndice C - Jogos propostos ao Instituto Fukuda …………………………………..... 131

Apêndice D - Questionário aplicado junto aos alunos...................................................... 133

Apêndice E - Roteiro de entrevistas com os professores ............................................... 135

Apêndice F - Apostila para professores de violoncelo ……………………………....... 137

Apêndice G - Termo de consentimento livre e esclarecido ............................................... 151

Apêndice H - Autorização solicitada ao Instituto Baccarelli........................................... 152

Apêndice I - Autorização solicitada ao Projeto Guri ........................................................ 153

Apêndice J - Autorização solicitada ao Instituto Fukuda .................................................. 154

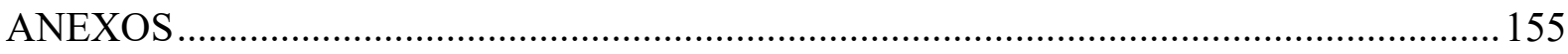

Anexo A - Partituras criadas pelos alunos na atividade Composição com gravuras e escrita

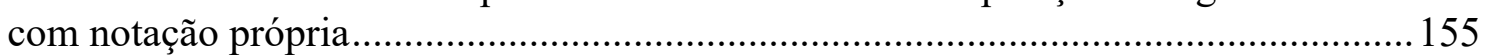





\section{INTRODUÇÃO}

A ideia para a realização desse trabalho foi concebida em minha atuação enquanto violoncelista e professora do instrumento em minha cidade, Porto Alegre. A partir de minhas experiências docentes, sempre refleti sobre as facilidades e dificuldades dos meus alunos frente à interpretação, criação e improvisação musical. E essas reflexões se intensificaram na medida em que, em diversas oportunidades, como masterclasses, festivais e eventos em diferentes regiões do país, eu percebia que tais facilidades e dificuldades não eram exclusivas dos meus alunos, já que também as percebia em estudantes de outros contextos, cidades e regiões. Dois aspectos me chamavam a atenção nos alunos - meus e de outros colegas - e me motivaram a realizar essa pesquisa. Por um lado, observava que a maioria dos estudantes apresentava dificuldades em relação à autoria de suas interpretações, dependendo quase sempre da orientação e aval de um professor ou de uma gravação de um artista consagrado para realizála. Por outro lado, durante a análise de diferentes textos produzidos por alunos do curso de Mestrado em Música (Violoncelo) do Programa de Pós-Graduação em Música da Universidade Federal do Rio Grande do Norte (PPGMus/UFRN), especializado em música contemporânea, constatei que muitos estudantes relataram que suas experiências com música contemporânea facilitaram a sua interpretação de músicas de diferentes períodos, justamente por possibilitarem maior autoria artística.

Com base nessas duas observações, formulei a hipótese de que, se as características coincidentes da estética e da educação musical da atualidade fossem contempladas também no ensino instrumental do violoncelo, esse ensino poderia ser mais efetivo e libertador, possibilitando que os estudantes se sentissem à vontade para elaborar suas próprias interpretações musicais. Algumas dessas características comuns estão relacionadas com a atenção na escuta, a improvisação, a criação e o uso de técnicas instrumentais não convencionais. Fixei minha atenção nas abordagens relacionadas às práticas de improvisação e direcionei a pesquisa desse trabalho para tais propostas. Essa opção ocorreu por ter sido vivenciada uma experiência anterior em umas das instituições em que eu atuava como docente. Acredito, porém, que os tópicos levantados se complementam e atuam de maneira conjunta.

A pouca oferta de atividades relacionadas à música contemporânea nas aulas de violoncelo já havia sido apontada pelo educador e violoncelista Fabio Presgrave (2008). Segundo Presgrave, "ao analisarmos o currículo das escolas brasileiras, vemos que grande parte dos alunos concluem um curso de Bacharelado sem terem ao menos lido uma peça escrita a 
partir de 1950” (PRESGRAVE, 2008, p. 2). Tal observação se complementa com a constatação do pesquisador Rogério Costa (2016) sobre os cursos de percepção musical das escolas de música no Brasil. Costa (2016) afirma que muitos desses cursos "se inserem em uma mentalidade que visa principalmente o aprendizado de uma série de habilidades relacionadas a um tipo de conhecimento musical pré-estabelecido e cristalizado" (COSTA, 2016, p. 82). Para o autor, o repertório escolhido para desenvolver tais habilidades é o repertório limitado ao campo da música ocidental europeia, dentro de um período chamado de "prática comum", que abarca do Barroco ao Romantismo. As constatações desses educadores se aliaram à minha observação de que as mudanças nos conceitos e ideias da educação musical dos séculos XX e XXI, muitas vezes, não chegam às aulas de instrumento, que ainda se baseiam, frequentemente, em um ensino voltado para a aquisição de habilidades técnicas e do repertório dos períodos denominados por Costa (2016) como “prática comum".

A experiência pessoal relativa à prática da improvisação no ensino coletivo do violoncelo a qual tomei como base de inspiração para essa pesquisa foi realizada no ano de 2012, no Instituto Popular de Arte-Educação (IPDAE) ${ }^{1}$, em Porto Alegre, e foi conduzida pelo violoncelista argentino Juan Ignacio Ferreras ${ }^{2}$. Em tal oportunidade, foram apresentadas aos alunos diferentes técnicas estendidas e, junto a eles, foi trabalhada a prática da improvisação por senhas ${ }^{3}$, prática com a qual o violoncelista ministrante era familiarizado, como integrante do grupo de violoncelos argentinos ARRE! Nessa ocasião, foi composta, em conjunto, pelos estudantes e professor, uma peça baseada em elementos do folclore argentino e elementos da improvisação por senhas. Foi possível constatar, por meio dessa experiência, que as atividades de improvisação eram compatíveis com as possibilidades técnicas e musicais dos alunos iniciantes ao violoncelo. Em tal ocasião, os alunos que participaram dessa oficina recebiam aulas de violoncelo havia cinco meses. O registro dessa prática encontra-se disponível em um vídeo no site YouTube, sob o título Desconcierto Musical-Final del taller para cellos dictado en IPDAE $E^{4}$.

\footnotetext{
${ }^{1}$ Organização Não-Governamental, situada na cidade de Porto Alegre- RS, que oferece aulas de música, incluindo o ensino e aprendizagem do violoncelo.

${ }^{2}$ Violoncelista argentino natural de Puerto Madryn, desenvolve diversas atividades artísticas em Buenos Aires, envolvendo a improvisação, a música popular e a interdisciplinaridade de linguagens, incluindo a dança, as artes plásticas e a poesia.

${ }^{3}$ Modalidade de improvisação dirigida, onde existe um maestro que coordena o trabalho musical. São estabelecidos alguns sinais, ou senhas, que representam determinadas sonoridades ou maneiras de execução, sendo que o maestro fornece as indicações aos músicos, dependendo das resultantes sonoras desejadas por ele. Os sinais, ou senhas, são combinados previamente com o grupo e expressos pelo maestro através de diferentes atitudes corporais.

${ }^{4}$ Disponível em: https://www.youtube.com/watch?v=-h-16WJRgg8\&feature=youtu.be
} 
A minha atuação enquanto professora de violoncelo em Porto Alegre, anterior à realização dessa pesquisa, era direcionada à iniciação dos alunos ao violoncelo, levando-os até o nível de ingresso na universidade de música. Tal atuação se desenvolvia principalmente em duas diferentes instituições: inicialmente, no já citado Instituto Popular de Arte-Educação (IPDAE) e, posteriormente, no projeto Filarmônica de Violoncelos-Tchêllistas ${ }^{5}$. Em ambos os projetos, as estratégias pedagógicas giravam em torno da aplicação do Método Suzuki, em aulas individuais ou coletivas, e na prática coletiva de músicas de diferentes períodos e estilos, no formato de orquestra de violoncelos. O Método Suzuki, elaborado pelo educador japonês Shinichi Suzuki (1898-1998), prevê o estudo de uma série de músicas compiladas e ordenadas por ele para o ensino do violino. É baseado na aprendizagem da língua materna e sua aplicação musical se dá sob forma da memorização sistemática de um repertório fixo, construtor da bagagem técnica e artística do aluno. Essa estrutura pedagógica foi posteriormente adaptada por outros educadores para o violoncelo e para outros instrumentos.

As peças do repertório da orquestra de violoncelos utilizadas no trabalho em Porto Alegre eram recolhidas do cancioneiro brasileiro, tanto de peças do folclore, quanto do repertório infantojuvenil da música popular, além de abordar outros referenciais com os quais os alunos estavam familiarizados, como por exemplo, o rock. Também eram trabalhadas junto aos alunos peças do repertório erudito, que incluíam desde peças consagradas pela tradição musical eurocêntrica, até peças do repertório brasileiro de concerto, adaptadas para essa formação.

Os arranjos e adaptações utilizados no trabalho nessas instituições eram baseados, principalmente, em minha própria experiência enquanto intérprete. Eram utilizados alguns elementos da música contemporânea e das técnicas estendidas, visando à aproximação dos alunos a esse tipo de repertório. A minha atuação enquanto intérprete incluía a participação no Grupo de Música Contemporânea de Porto Alegre, o GMC-POA, e a colaboração com compositores dos cursos de graduação, mestrado e doutorado da Universidade Federal do Rio Grande do Sul (UFRGS). Junto a esses grupos, pude realizar algumas estreias de peças modernas, destacando-se a gravação da obra Pression, do alemão Helmut Lachenmann e a estreia de Solo para Marta, do argentino Germán Gras.

Alguns desses arranjos foram também produzidos por meio de um trabalho conjunto com compositores da cidade de Porto Alegre. A produção de tal repertório visava diminuir

\footnotetext{
${ }^{5}$ Projeto social destinado ao ensino e aprendizagem do violoncelo, situado na cidade de Porto AlegreRS.
} 
algumas lacunas encontradas durante o processo de ensino do violoncelo nessas instituições. Em ambas as instituições, os alunos passavam pelo processo de musicalização durante as aulas de instrumento, sem outras aulas específicas para essa finalidade. Parte das dificuldades encontradas durante essa abordagem foi relatada em um artigo no ano de 2014, publicado na IV Mostra de Violoncelos de Natal.

O professor de violoncelo no Brasil, quando inserido em processos de musicalização, encontra algumas dificuldades que precisa contornar para criar condições propícias à aprendizagem. Precisa descobrir metodologias de ensino adequadas para alunos iniciantes, promover uma educação musical de qualidade e ao mesmo tempo transmitir os conhecimentos necessários para o desenvolvimento da técnica do instrumento. Neste sentido, a maior carência que o professor enfrenta é a falta de métodos didáticos modernos e de repertórios que estabeleçam vínculos com a musicalidade dos alunos, isto é, com suas vivências musicais anteriores a aula de violoncelo (BRIETZKE, VILLENA, 2014).

Além dos questionamentos e experiências apontados, a motivação para a realização dessa pesquisa originou-se também através da aproximação com as ideias de educadores musicais da história recente, que enfatizam abordagens relacionadas às práticas de improvisação. Destacam-se as ideias de François Delalande (2001), Hans-Joachin Koellreutter (1997), Violeta Gainza (2009) e Carlos Kater (2017), com as quais eu possuía afinidade mesmo antes da realização dessa pesquisa.

O objetivo desse trabalho é investigar a implementação dos jogos de improvisação na iniciação coletiva ao violoncelo, aproximando os alunos às poéticas da música contemporânea. A justificativa para sua elaboração reside na pouca oferta de material pedagógico disponível aos professores de violoncelo que desenvolvam atividades de criação e que possibilitem tal aproximação. A pesquisa busca relacionar o ensino e aprendizagem do violoncelo com as perspectivas da música atual.

Para a realização da pesquisa foram selecionados, no estado de São Paulo, grupos com identidade semelhante àqueles pertencentes às instituições de Porto Alegre nas quais eu atuava como docente. Também foi idealizada a realização da experiência em mais de uma instituição, a fim de testar com maior eficiência as propostas sugeridas. Por esses motivos, foram escolhidos três grupos distintos, o Instituto Baccarelli, o Projeto Guri-Polo de Indaiatuba e o Instituto Fukuda. O Instituto Baccarelli e o Projeto Guri são iniciativas de cunho social, enquanto o Instituto Fukuda é uma escola particular de música. Em comum, e em comum com as instituições de Porto Alegre onde era desenvolvido meu trabalho docente anterior, essas instituições possuem a característica de trabalhar coletivamente o ensino do violoncelo, sem contar com atividades de musicalização paralelas ao trabalho realizado no instrumento. 
Tanto no Instituto Baccarelli, quanto no Projeto Guri, a iniciação ao violoncelo se dá em forma de aulas coletivas. No Projeto Guri existe uma característica peculiar que é o fato das aulas de violoncelo serem ministradas em conjunto com as aulas de contrabaixo. Já no Instituto Fukuda, os alunos recebem aulas individuais e coletivas, formando uma orquestra de violoncelos. Porém, as aulas coletivas são destinadas aos alunos avançados, que já possuem bastante tempo de estudo no instrumento. $\mathrm{Na}$ ocasião da realização da pesquisa o diretor do Instituto Fukuda expressou seu desejo em retomar as aulas coletivas de violoncelo para iniciantes, que no momento não estavam sendo realizadas.

As três instituições escolhidas desenvolvem seu trabalho visando a criatividade e a liberdade artística dos alunos, porém, a prática da improvisação não era aplicada por nenhuma delas em suas atividades pedagógicas. No Instituto Baccarelli, a estratégia utilizada para a iniciação ao violoncelo também é o Método Suzuki, enquanto no Projeto Guri, cada professor tem a liberdade de escolher a maneira mais adequada para o trabalho com as diferentes turmas de alunos. Dessa maneira, verifiquei que a aplicação prática da proposta, baseada em modelos de jogos de improvisação, foi uma novidade para todas as instituições abordadas. Tal proposta, porém, vinha ao encontro dos seus interesses e objetivos pedagógicos. Por essa razão, ela foi bem recebida pelas instituições, como uma estratégia viável e compatível com os processos educativos adotados por cada uma delas.

$\mathrm{Na}$ literatura pesquisada, há poucas referências no que diz respeito à prática da improvisação ligada ao ensino e aprendizagem do violoncelo (SOUZA, 1998; SOUZA, 2014; ESTEVES, 2015). Embora alguns professores tenham sugerido que a improvisação é uma importante estratégia para a aprendizagem do instrumento, não disponibilizam pesquisa e material didático destinado a essa aplicação. Buscando referências para o trabalho, foram encontradas, então, práticas relacionadas ao ensino instrumental de outros instrumentos, como o piano, a flauta doce e o violão.

Tendo em vista a pouca literatura ligada às práticas de improvisação direcionadas ao violoncelo, foram utilizadas, também como referências, as ideias de alguns educadores, pesquisadores e pensadores que se dedicam ao estudo da improvisação em múltiplas dimensões. Entre eles, se destacam principalmente as concepções de François Delalande (2001), Chefa Alonso (2009), Wade Matthews (2012), Violeta Gainza (2009), Derek Bailey (1993), Bruno Nettl (2004), Rogério Costa (2016) e Carlos Kater (2017). Também contribuíram para as concepções gerais da pesquisa o pensamento de John Dewey (2010) e Jorge Larrosa Bondía (2002), que abordam temas considerados relevantes para o trabalho, como a prática da experiência artística e a aprendizagem através da experiência. 
Esse trabalho se divide em cinco capítulos, sendo o primeiro capítulo destinado à presente introdução, em que apresento o contexto em que surgiu a ideia da pesquisa, seus objetivos e justificativas, bem como ocorreu a escolha das instituições que participaram do trabalho. O segundo capítulo se estrutura sobre a revisão bibliográfica e o referencial teórico adotado pela pesquisa. O capítulo está configurado em três seções, que discutem diferentes aspectos. Na seção 2.1, proponho considerações sobre a prática da música contemporânea na formação instrumental, analisando as ideias de alguns autores e também, diferentes trabalhos que atuam dentro destas concepções. Em 2.2, teço considerações a respeito de ideias e conceitos de improvisação, trazendo as principais abordagens de utilização dessa prática com fins didáticos. Associo essas práticas às diferentes concepções de jogos e suas relações com a arte e com a música e à algumas ideias do educador John Dewey e do pensador Jorge Larrosa Bondía, que dialogam com as práticas de improvisação e com considerações abordadas pelos educadores musicais em relação às suas finalidades educativas. Por fim, na seção 2.3, contextualizo a abordagem dessa pesquisa dentro do modelo coletivo de ensino de instrumento musical, trazendo considerações sobre sua origem, sua aplicação no Brasil e suas principais características.

No terceiro capítulo desse trabalho, trato das bases teórico-metodológicas adotadas na pesquisa. Descrevo a escolha da abordagem e do método, respectivamente, a abordagem qualitativa e o método de pesquisa-ação, destacando suas principais características e a maneira como foram adotados nessa pesquisa. Em seguida, relato sobre os instrumentos e técnicas de coleta de dados utilizados, que se configuram como Diário de Campo, questionários, entrevistas semiestruturadas, anotações dos alunos e a gravação de algumas atividades em vídeo. Também analiso a maneira como se estabeleceu a categorização desses dados, por meio da organização do Diário de Campo, tabulação dos dados dos questionários, transcrição das entrevistas e categorização das anotações dos alunos e das gravações em vídeo. Por fim, trato dos princípios éticos que marcaram a realização da pesquisa.

O quarto capítulo do trabalho está destinado à caracterização das instituições envolvidas na pesquisa, dos participantes e da intervenção proposta na pesquisa de campo. Inicialmente, traço um perfil das três instituições envolvidas no trabalho, bem como o perfil dos professores e dos estudantes que participaram das atividades. Em seguida, relato a proposta de aplicação dos jogos selecionados, estabelecendo seus objetivos gerais, objetivos específicos, autores e metodologia de aplicação.

O quinto e último capítulo está destinado a relatar a implementação dos jogos de improvisação e a realizar a análise e avaliação do trabalho. Inicialmente relato a maneira como 
cada jogo foi aplicado nas instituições, trazendo excertos das minhas anotações no Diário de Campo. Posteriormente trago as considerações dos alunos e dos professores em relação ao trabalho desenvolvido, associando tais considerações com a literatura da área e com minhas observações pessoais, propondo a triangulação dos resultados.

Por fim, são apresentadas as obras de referência, os apêndices e os anexos do trabalho. Nos apêndices, estão inclusos os jogos apresentados às instituições, o questionário aplicado aos alunos, o roteiro das entrevistas semiestruturadas realizadas com os professores, a apostila direcionada a professores de violoncelo, contendo, além das atividades aplicadas durante as aulas e encontros da pesquisa de campo, embasamento teórico sobre alguns dos tópicos levantados nesse trabalho, e as partituras elaboradas pelos alunos das instituições envolvidas no trabalho em uma das atividades realizadas. Nos anexos encontram-se o termo de consentimento solicitado aos professores e a autorização solicitada aos alunos para a realização desse trabalho. 


\section{MÚSICA CONTEMPORÂNEA E JOGOS DE IMPROVISAÇÃO: POSSIBILIDADES PARA O ENSINO COLETIVO DE INSTRUMENTO}

Neste capítulo, abordo algumas ideias a respeito da música contemporânea em relação à formação instrumental e também concepções e perspectivas sobre jogos de improvisação e sua inserção nas poéticas relacionadas a estas concepções estéticas. São apontadas as principais características e aplicações da improvisação enquanto estratégia pedagógica, concebidas por diferentes educadores musicais. Também é realizada uma revisão sobre algumas ideias e conceitos de jogo, segundo distintos pensadores, procurando compreender como é feita a associação entre o jogo, a arte e a aprendizagem musical. Além desses tópicos, são abordadas algumas concepções sobre arte, educação e experiência, do filósofo e educador norteamericano John Dewey (1859-1952) e do pensador espanhol Jorge Larrosa Bondía, relacionando-as com a aprendizagem musical por meio dos jogos de improvisação, através da conexão dessas ideias com algumas concepções de educadores musicais. Completando o capítulo, são apresentadas algumas considerações sobre o ensino coletivo de instrumentos musicais, modelo sobre o qual essa pesquisa está estruturada.

\subsection{MÚSICA CONTEMPORÂNEA E FORMAÇÃO INSTRUMENTAL}

De acordo com Presgrave (2008, p. 2), os cursos de Bacharelado em Música, comumente, proporcionam um contato pouco significativo dos estudantes de violoncelo com a música contemporânea. Vale destacar que o termo, inclusive, nem mesmo possui um conceito que seja unânime ou amplamente compartilhado na academia. Utilizada por diversos pesquisadores, intérpretes, professores e estudantes da área, a expressão ainda carece de uma definição precisa, que tenha potencial para se tornar consensual. Isso, para Mojola (2009), se deve ao fato de as duas áreas de conhecimento com maior potencial para produzir teorização sobre o tema - Musicologia e Etnomusicologia - ainda não trazerem uma solução epistêmica satisfatória para a questão. Dito isso, Zagonel (2007) esclarece que, em meios acadêmicos, o termo é, mais frequentemente, utilizado para designar a música europeia de concerto dos séculos XX e XXI, orientada esteticamente pelas profundas mudanças filosóficas, científicas, culturais e tecnológicas do período. Dessa forma, "é importante que o ouvinte que se dispõe a ouvir Música Contemporânea se desprenda de seus paradigmas antigos, e abra suas percepções para entender e apreender outras formas de expressão musical” (ZAGONEL, 2007, s/p). Com base no exposto, parto das proposições de Mojola (2009) e Zagonel (2007) para conceber 
'música contemporânea', nesse trabalho, como a produção musical ligada à música de concerto e vinculada a propostas artísticas engendradas a partir do século XX, marcadas pela complexidade, imprevisibilidade, dissolução e permeabilidade de referências artístico-culturais e filosóficas diversas.

Apesar dessa dissolução e permeabilidade entre os sistemas se constituir em uma característica já consolidada de diferentes maneiras desde meados do século $\mathrm{XX}$, ainda hoje, com frequência, parte dos músicos profissionais não é familiarizada e inclusive não gosta de tocar ou ouvir a música que envolva possibilidades sonoras distintas das produzidas em séculos anteriores, relativas às "poéticas" da música contemporânea. Foi escolhido para esse trabalho a utilização do termo "poética" para se referir à concepção de música não apenas enquanto linguagem, mas como expressão artística fundamentada nas concepções filosóficas, estéticas, históricas, sociais e políticas do seu entorno e, até mesmo, em elementos biográficos dos artistas. Tal concepção se apoia na visão de Suhamy (1992), que aponta que "quando falamos da poética de um autor, designamos o que contribui à coerência e ao simbolismo de sua visão, suas imagens recorrentes ou abundantes, suas obsessões elementares ou instintivas, seu vigor sensorial, em detrimento de sua métrica, suas escolhas formais e sua temática aparente" (SUHAMY, 1992, apud ARAÚJO, 2017, p. 114).

Os fundamentos do uso do termo "poética" datam a antiguidade clássica, através da proposição teórica do filósofo grego Aristóteles. Na obra homônima do autor, Poética, são propostos, entre outros aspectos, o estudo das espécies e das respectivas características envolvidas na constituição do poema, da trama requerida para sua composição, do número e da natureza de suas partes constitutivas e também em aspectos que interessam à sua investigação (ARISTÓTELES, 1997, p. 3). O uso do termo "poética" passou a ser adotado na contemporaneidade em outras esferas das manifestações artísticas, além da originalmente proposta por Aristóteles, como por exemplo, as artes visuais, as artes cênicas e a música. Segundo Araújo (2017), “concerne a todas as artes, ou melhor, a tudo aquilo que é produzido fazendo uso deliberado de uma composição estética” (ARAÚJO, 2017, p. 113).

Algumas dessas poéticas, segundo Zagonel (2007), fazem parte de certas tendências composicionais, que a autora explicita, sem pretender esgotar a multiplicidade das manifestações artísticas surgidas nos séculos XX e XXI. Segundo a autora, podemos enumerar algumas dessas tendências, citando correntes como impressionismo, nacionalismo, politonalidade, atonalismo, expressionismo, pontilhismo, dodecafonismo, serialismo integral, neoclassicismo, microtonalismo, música concreta, música eletrônica, música eletroacústica, música aleatória, minimalismo, além da influência do jazz, do folclore e da música do oriente 
(ZAGONEL, 2007, s/p). Mattos (2016), ao trazer reflexões sobre essas tendências, situa a produção musical relativa aos séculos XX e XXI, organizando-as em três frentes distintas: continuidade da modernidade, retorno à tradição e superação do modernismo (MATTOS, 2016, p. 57). Porém, o autor esclarece que, essas tendências se interconectam, as vezes, inclusive, em uma única peça.

Quando o músico se torna mais receptivo às diferentes opiniões que circulam no campo da estética musical, percebe, também, que diferentes processos musicais podem ser combinados em uma única peça de música, não importando onde ou quando esses processos se originaram. Essas fontes podem ser justapostas, uma após a outra, na sequência de eventos sonoros, assim como podem ser sobrepostas em um único momento do tempo musical. Isso depende de vários fatores, muitos deles ligados aos anseios do próprio artista. Também se abrem novas possibilidades de significação através da música, que não permanece restrita a valores exclusivamente técnicos ou formais (MATTOS, 2016, p. 88).

No contexto da educação musical, com o intuito de aproximar os estudantes de música dessas poéticas, algumas iniciativas vêm sendo protagonizadas por diferentes músicos e professores, buscando incorporar esse repertório e essas possibilidades às práticas dos estudantes. A abordagem de tais peças, com viés educativo, porém, não é nova, apesar de ser escassa, pouco divulgada e pouco adotada pelos professores de instrumento. Destacam-se as iniciativas de alguns compositores do século XX, como por exemplo, Béla Bartók e Boris Porena. Béla Bartók (1881-1945) escreveu peças como os 44 duos para dois violinos (1992), originalmente compostos em 1931, encomendados ao compositor pelo professor de violino Erich Doflein, For Children (2015-2016), original de 1908, direcionado para pianistas iniciantes e Mikrokosmos (2016), escrito entre 1926 e 1939, que se constitui em uma coleção de 153 peças para piano, que possuem como característica o aumento progressivo de dificuldades técnicas e musicais. O compositor italiano Boris Porena, através do seu livro Kindermusik (2017), publicado originalmente em 1973, aborda a prática de diferentes instrumentos e da voz. A pesquisadora Marisa Fonterrada (2008) destaca ainda o compêndio Jeunes musiques: Collection de partitions de musique contemporaine pour enfants et musiciens débutants, editado em dois volumes e que abriga material dedicado à distintas formações, incluindo a voz e instrumentos variados, como por exemplo, instrumentos de altura não definida, instrumentos de sopro, de cordas e o piano. Este compêndio é constituído por obras de diferentes compositores, como David Bedford, Alan Brett, Brian Dennis, George Self, Howard Skempton, Murray Schafer, Bernard Rands, Elizabeth Flusser e Heinz Kratchwill.

Algumas iniciativas se destacam também no Brasil, como por exemplo, a protagonizada por Heitor Villa-Lobos (1887-1959) ao escrever peças com caráter pedagógico 
para piano. Entre elas, as obras Brinquedo de Roda (1912), Carnaval das Crianças (1919-1920) e a coleção Cirandinhas (1925), formada por doze peças curtas. Além de Villa-Lobos, o compositor alemão, naturalizado brasileiro, Ernest Mahle dedica grande parte de sua produção à elaboração de peças com viés didático, direcionadas a diferentes formações instrumentais, estimuladas por sua atuação pedagógica em Piracicaba/SP. Também contemplam a formação instrumental o conjunto de peças elaboradas pelo compositor Bruno Kiefer (1923-1987). Assim como Mahle, Kiefer nasceu na Alemanha e se naturalizou brasileiro, fixando residência em Porto Alegre/RS. Kiefer dedicou o trabalho Música para gente miúda (1986) para conjuntos de flautas doces, violino e violão, buscando propor material formativo que contemplasse os instrumentos oferecidos em aulas de música de um projeto de extensão universitária da Universidade Federal do Rio Grande do Sul (UFRGS).

Outros compositores brasileiros também se dedicaram a escrever peças com viés formativo para violoncelistas, como por exemplo, os compositores que fizeram parte do livro, intitulado Violoncelo XXI: estudos para aprender a tocar e apreciar a linguagem da música contemporânea (2012), organizado por Silva, Aquino e Presgrave. O livro foi elaborado disponibilizando peças de 12 compositores de diversas regiões do Brasil: João Victor Bota, Dimitri Cervo, Rogério Luiz Costa, Maurício de Bonis, Alexandre Ficagna, Marcílio Onofre, Gustavo Penha, Liduino Pitombeira, Marisa Resende, Vanessa Rodrigues, Marcus Siqueira e Roberto Victorio. Também se dedicou à tarefa de escrever peças com caráter didático destinadas ao violoncelo o compositor Sílvio Ferraz, através da produção de cinco duetos para dois violoncelos, datados no ano de 2012. Além de peças inéditas para violoncelo, alguns compositores também se dedicam a concepção de arranjos com viés pedagógico, abordando as poéticas da música contemporânea. Entre eles, o compositor Bruno Angelo, natural do Rio Grande do Sul e o argentino Marcelo Villena, residente no estado do Paraná. Esses compositores escreveram, respectivamente, os arranjos das peças Negrinho do Pastoreio (2013), originalmente composta por Barbosa Lessa e o arranjo/composição Bôôoi!! (2013), baseado em melodias do folclore catarinense, ambos direcionados para orquestra de violoncelos de nível iniciante.

Durante a revisão bibliográfica dessa pesquisa, a literatura consultada apontou para a ideia de que alguns elementos abordados pelas poéticas da música contemporânea, coincidem com algumas concepções dos educadores musicais dos mesmos períodos. Um desses elementos é a exploração dos instrumentos de maneiras mais abrangentes, maneiras não convencionais de produção sonora, também chamadas, em linguagem formal, de técnicas estendidas. Conforme já relataram José Henrique Padovani e Sílvio Ferraz (2011), apesar do uso das técnicas 
estendidas ter se consolidado na música dos séculos XX e XXI, essas já eram utilizadas, de diferentes maneiras, em outros períodos da história da música ocidental.

Tradicionalmente associada às técnicas de performance instrumental, a expressão técnicas estendidas se tornou comum no meio musical a partir da segunda metade do século XX, referindo-se aos modos de tocar um instrumento ou utilizar a voz que fogem aos padrões estabelecidos principalmente no período clássico-romântico. Em um contexto mais amplo, porém, percebe-se que em várias épocas a experimentação de novas técnicas instrumentais e vocais e a busca por novos recursos expressivos resultaram em técnicas estendidas. Nesta acepção, pode-se dizer que o termo técnica estendida equivale a técnica não-usual: maneira de tocar ou cantar que explora possibilidades instrumentais, gestuais e sonoras pouco utilizadas em determinado contexto histórico, estético e cultural (PADOVANI; FERRAZ, 2011, p. 11).

Considerando-se a exploração também como um recurso individual do instrumentista e as diferenças timbrísticas de cada instrumento, pode-se dizer que as possibilidades sonoras geradas pelas técnicas estendidas são bastante vastas. Diferentes instrumentistas produzirão diferentes e sutis resultantes sonoras, mesmo interpretando a mesma peça. Segundo o educador e também compositor François Delalande ${ }^{6}$, ao começar a estudar um instrumento musical, frequentemente, os alunos possuem uma postura semelhante à do compositor de música concreta, a necessidade exploratória com fins expressivos dos corpos sonoros, no nosso caso, o violoncelo (DELALANDE, 2001, p. 15). Observa-se essa necessidade na tendência natural do aluno em percutir, raspar, friccionar, e produzir diferentes ações com resultados sonoros diversos. Na maioria das vezes, essa necessidade é reprimida pelos professores, por ser considerada um risco à integridade do instrumento, que necessita de uma maneira específica de manuseio.

Também segundo Delalande (2001), as crianças e adolescentes, na fase inicial do estudo de música, não possuem preconceitos estéticos como os que são demonstrados por alunos ou músicos mais avançados tecnicamente. Tal observação leva à conclusão de que as dificuldades de compreensão da música contemporânea por alguns músicos profissionais pode ser uma dificuldade relacionada à repetição sistemática de determinados estilos musicais em detrimento de outros, justamente os ligados à música produzida nos séculos XX e XXI. As pesquisas de Delalande (2001) apontam para a perspectiva de que uma das maneiras de começar a ensinar o repertório da música contemporânea seria permitindo que o aluno exerça sua

\footnotetext{
${ }^{6}$ François Delalande (1941) é compositor, pesquisador e educador francês, integrante do GRM (Group de Rechérches Musicales). Tal grupo fundado em 1958 por Pierre Schaeffer, associado inicialmente às pesquisas de música concreta, atua também em pesquisas relacionadas a práticas pedagógicas, através do CREAMUS - L'espace de pédagogique du GRM.
} 
curiosidade natural em explorar os sons do entorno, entre eles, os sons que podem ser produzidos pelos instrumentos.

$\mathrm{O}$ uso das técnicas estendidas também vem sendo associado à ideia de mimese, presente em determinadas abordagens da música contemporânea, como por exemplo, as relacionadas a paisagem sonora e a narratividade. Tal uso pode proporcionar também uma abordagem pedagógica, assim como destacado por autores como Brietzke e Villena (2014). A mimese se configura, de maneira geral, como o procedimento artístico de "imitar" ou "representar" modelos sonoros da natureza, ou de caráter psicológico. Segundo Villena (2013) o termo mimese, possivelmente foi utilizado desde a Grécia antiga, onde, era destinado às práticas envolvendo perspectivas miméticas, um importante valor no contexto ético/educativo (VILLENA, 2013, p. 20). O uso da mimese associado à pedagogia do violoncelo no Brasil, destacado por Brietzke e Villena (2014), busca, através da elaboração de um arranjo/composição, proporcionar aos estudantes a aproximação com as técnicas estendidas. Para os autores, mimese foi pensada como uma forma lúdica de apresentar concepções musicais diferentes das tradicionalmente utilizadas pelos alunos, fazendo usos não convencionais dos instrumentos, para estimular as associações mentais com as sonoridades do entorno (BRIETZKE/ VILLENA, 2014, p. 6).

Além do uso das técnicas estendidas, a prática da improvisação, principalmente em suas abordagens ligadas à livre improvisação (tema que será tratado mais adiante), muitas vezes, apresenta "resultados" musicais e propostas de escuta, semelhantes às de outras estéticas da música contemporânea, principalmente a música concreta, porém, não apenas dessa. Sendo assim, se insere também dentro do contexto pedagógico relativo às suas abordagens. Costa (2016) situa a livre improvisação como tendo sido preparada por uma série de fatores presentes da história e geografia da música (COSTA, 2016, p. 14), que se inserem dentro do contexto da música contemporânea. Para o autor, alguns fatores e referências que tornam possíveis as práticas de livre improvisação estão conectados com compositores como Pierre Schaffer, Edgar Varése, John Cage, Luciano Berio, Giancinto Scelsi, Olivier Messiaen e Charles Ives. O autor considera como fator importante, em concordância com citação do compositor Helmut Lachenmann, em relação à "emancipação do som", que "grande parte das mudanças significativas nas práticas musicais atuais são o resultado desse recentramento sobre o som e da superação dos limites entre o som e o ruído" (COSTA, 2016, p. 19). Dessa maneira, integram o universo das proposições dos jogos de improvisação pesquisados, as concepções musicais surgidas no decorrer das novas significações estéticas das poéticas da música contemporânea. 
Conectando-se com as ideias apresentadas, o estudo das práticas de improvisação, enfatizando suas abordagens pedagógicas e sua relação com características lúdicas da música, se configurou em um importante viés para a compreensão dessa manifestação dentro das possibilidades de aproximação dos estudantes de violoncelo com as poéticas da música contemporânea. Sendo assim, passo a contemplar a revisão bibliográfica sobre algumas ideias e conceitos relacionados à prática da improvisação e sua aplicação pedagógica.

\subsection{A IMPROVISAÇÃO E SEU USO NA EDUCAÇÃO MUSICAL}

A improvisação, enquanto prática de criação musical, vem se constituindo em uma das principais estratégias pedagógicas disponíveis aos educadores musicais da atualidade. Com frequência os educadores musicais também associam à improvisação, ideias de jogo, denominando as atividades relacionadas com essas práticas como "jogos musicais" ou "jogos de improvisação". Esse trabalho revisou algumas ideias sobre improvisação e sua utilização pedagógica, abordando também diferentes concepções que relacionam a arte ao jogo, procurando compreender as características lúdicas da música e situando a pesquisa de campo realizada nas três instituições de ensino dentro desse contexto.

No senso comum, as ideias sobre improvisação são diversas, sendo o termo amplamente presente nos discursos de profissionais, professores, pesquisadores e estudantes de música. No âmbito acadêmico-científico, contudo, poucas vezes se atribui um conceito claro ao termo. Geralmente, parte-se do pressuposto de que o interlocutor(a) 'sabe do que estamos falando'. Essa percepção não é nova. Em trabalhos das décadas de 1990 e 2000, Derek Bailey (1993) e Bruno Nettl (2004) destacaram que, na literatura acadêmica até então produzida, havia poucas referências sobre improvisação, sendo poucas as pesquisas que a tomavam como objeto de estudo.

Bailey (1993) enfatiza em seu texto que, mesmo estando a improvisação presente em quase todas as áreas da música, havia uma quase total ausência de informações sobre o assunto (BAILEY, 1993, p. ix). Nettl (2004), por sua vez, alertou que essa forma de fazer música estava relativamente descuidada pelos pesquisadores (Nettl, 2004, p. 9). Assim como Bailey (1993), o autor apontou que, comumente, os músicos que praticam a improvisação, em diferentes culturas, não usam essa palavra para definir sua arte, pois não raramente se atribui a essa palavra, uma conotação negativa, ligada à ausência de planejamento e disciplina, à falta de formação musical elementar e à uma arte menor, destinada à uma posição inferior dentro da sociedade musical (Nettl, 2004, p. 16). Em contrapartida, Nettl (2004) constata ainda que existe 
um consenso geral no mundo musicológico europeu sobre a definição básica de improvisação, que tradicionalmente se fundamenta como o ato de criação no momento da execução ou da performance da música (NETTL, 2004, p. 18). Citando a literatura existente, Nettl (2004) aborda alguns desses conceitos, como por exemplo, o adotado pelo New Grove Dictionary, que define a improvisação como "a criação de uma obra musical, ou a forma final de uma obra musical, durante sua interpretação"(Horsley et al 1980, 9:31 apud Nettl 2004, p. 18). Também cita ideias semelhantes de outros autores como Ernest Ferand, John Baily, Veit Earlmann, Micheál O’Suilleabhain e Simha Arom. Nettl considera, porém, que esses conceitos nem sempre são capazes de abarcar a variedade de manifestações da improvisação musical em diferentes culturas (NETTL, 2004, p. 14). Nesse trabalho vou me referir à improvisação, tendo em vista a complexidade dos fenômenos apontados pelos musicólogos referentes a essa prática em diferentes culturas, como um conjunto de expressões e práticas musicais que mobilizam o fazer e a criação musical em tempo real, um processo de constante invenção, que assim como sinaliza Costa (2016) "mobiliza por parte dos músicos um estado de prontidão auditiva, visual, tátil e sensorial" (COSTA, 2016, p. 12).

Cabe destacar que, embora quase ausente nas interpretações atuais das músicas da tradição europeia de concerto, a improvisação era comum nessas tradições até meados do século XIX, quando os papeis do compositor e do intérprete começaram a ser delineados como auto excludentes. A improvisação estava fortemente presente ainda nos períodos Barroco e Clássico, porém, no período Romântico essa prática foi desaparecendo, ao mesmo tempo em que foram se estabelecendo a especialização em diferentes áreas de atuação musical. O intérprete foi perdendo a capacidade de improvisar, acomodando-se ao papel de apenas reproduzir as ideias do compositor.

Em relação as diferentes classificações atribuídas a improvisação destacam-se as ideias de Derek Bailey (1993). A partir dessas ideias, costuma-se diferenciar a "improvisação idiomática" da "improvisação não-idiomática", que, conforme o autor, é mais comumente encontrada na "improvisação livre" (BAILEY, 1993, p. xii). Esses termos, embora amplamente utilizados, foram questionados, relativizados e problematizados por diferentes autores, inclusive o próprio Bailey. Alguns pesquisadores também consideram sinônimos, os termos “improvisação não-idiomática" e "improvisação livre”. Segundo Bailey (1993) a “improvisação idiomática" está ligada a determinados estilos ou "idiomas" musicais específicos, como o jazz, o choro e a salsa. A “improvisação não-idiomática” se diferencia dessa por não estar ligada a nenhum idioma específico, podendo incorporar diversas abordagens do conteúdo sonoro. 
Parte da problematização envolvendo o uso desses termos encontra-se na concepção de que mesmo em práticas "não-idiomáticas", "há, obviamente, as ações inconscientes, automatizadas e condicionadas pelas ideias de música, pelos idiomas que atravessaram os performers e/ou pela técnica adquirida num determinado instrumento em anos de estudo (memórias corporais) e que configuram seu conhecimento de base" (COSTA, 2017 p. 7). Menezes (2010) também considera que os elementos idiomáticos podem aparecer na improvisação "não-idiomática", porém, em nível subordinado (MENEZES, 2010, p. 15).

Já em relação à "livre improvisação", a problematização se constitui pela coexistência de uma gama de práticas que se autodenominam "livre improvisação", sendo que, muitas vezes, os limites entre essas práticas não são claros. Costa (2017) destaca algumas dessas manifestações: solistas ou grupos de improvisação livre instrumental, solistas ou grupos de improvisação mistos, música mista interativa, comprovisação, trabalhos de criação coletiva, soundpaiting e conducting. Também se aponta como "livre improvisação" as atividades das orquestras de improvisadores. Assim como considerou Menezes (2010), "tentar definir a improvisação livre a partir de um ângulo único perderia o mais notável de seus aspectos: sua capacidade de incorporar tantas perspectivas diversas, do social e cultural ao musical e estrutural"7 (MENEZES, 2010, p. 17, tradução nossa). Costa (2017) aponta como elemento comum a essas práticas, o foco na performance, que inclui, em maior ou menor grau, uma atuação ativa e criativa em tempo real (COSTA, 2017, p. 6).

Uma outra maneira de classificar as atividades de improvisação é através das especificidades que existem entre "improvisação dirigida", "improvisação semidirigida" e “improvisação livre”. Segundo Castro (2015), a "improvisação dirigida” também é chamada de "live composition" e é conhecida, no senso comum, como " um sistema de criação espontânea em que um regente/juiz utiliza gestos e/ou códigos para definir diretrizes e conduzir um grupo de participantes" (CASTRO, 2015, p. 23). Para o autor, essa é "essencialmente, uma forma de improvisação na qual parâmetros estruturais são fornecidos aos improvisadores, que por sua vez escolhem o conteúdo, a forma e técnica a serem executados" (CASTRO, 2015, p. 23). São consideradas pelo autor, formas de "improvisação dirigida", as já citadas soundpaiting e conduction. A "improvisação dirigida" teria se originado como uma variação da "improvisação livre". Em analogia a essas ideias, a "improvisação semidirigida" apresenta tanto elementos da “improvisação dirigida" quanto da "improvisação livre”. Conforme já citado anteriormente, e

\footnotetext{
${ }^{7}$ Trying to define free improvisation from a single angle would miss the most remarkable of its aspects: its capability to incorporate so many diverse perspectives, from social and cultural to musical and structural. (MENEZES, 2010, p. 17)
} 
referenciado pelos trabalhos de Costa (2016) e Menezes (2010), esses termos se interconectam, e muitas vezes, são aplicados para referirem-se a atividades com características semelhantes.

A “improvisação livre” também costuma ser tratada enquanto objeto artístico, e sob essa concepção surge na Alemanha e na Inglaterra no final dos anos sessenta do século XX, como um desenvolvimento natural do free jazz, da música contemporânea e da música folclórica (ALONSO, 2007, p. 35). Segundo Chefa Alonso ${ }^{8}$ (2007), diversos grupos de "improvisação livre" surgiram nessa época, até que nos anos setenta do mesmo século essa prática se estendeu como fenômeno para quase todo o mundo (ALONSO, 2007, p. 38). Costa (2016) afirma que "em termos mais abrangentes podemos dizer que a livre improvisação surge no contexto da superação do paradigma da nota e de sua substituição pelo paradigma do som" (COSTA, 2016, p. 19).

O objetivo da "improvisação livre" é estar atento, por intermédio da escuta, aos processos de criação que se desenvolvem num determinado contexto, e interagir com esses processos, realizando suas próprias contribuições. Não existe o erro em se tratando de “improvisação livre". O participante visa comunicar suas ideias por meio do uso dos elementos sonoros que vão sendo apresentados numa poética musical, ou ainda, por intermédio da improvisação, busca tornar sonoras, ideias não sonoras. Por suas características intrínsecas, distintos educadores musicais utilizaram em suas práticas pedagógicas as ideias e propostas da "livre improvisação".

O uso da improvisação enquanto estratégia pedagógica foi adotado de diferentes maneiras pelos educadores musicais desde a segunda metade do século passado. Émile JacquesDalcroze (1865-1950), por exemplo, desenvolveu um sistema denominado de Eurhythmics, no qual organizou e ordenou sua concepção pedagógica. A improvisação não era usada apenas após alguns anos de aprendizagem, mas em cada aula, como consequência do trabalho realizado, em que o professor propunha exercícios correspondentes aos conteúdos das aulas. Essas improvisações eram realizadas por meios vocais, instrumentais e corporais. Tais concepções estavam baseadas nos conceitos da música tonal. Influenciados por Dalcroze, outros educadores passaram a incluir a improvisação em suas abordagens pedagógicas - entre

\footnotetext{
${ }^{8}$ Chefa Alonso é compositora e instrumentista espanhola, doutora em Performing Arts (improvisação e composição musical) pela Universidade de Brunel (Londres). Se dedica ao ensino da improvisação e à condução de orquestras de improvisação, como por exemplo, a Orquestra de Improvisadores de Viena, Foco (Orquestra da associação Musicalibre), OMEGA (Orquesta de Música Espontánea de Galicia) e Enteguerengue (Orquestra de improvisadores de Andalucía). Atualmente atua em projetos interdisciplinares como a Orquesta Carníval e a Orquesta en Tránsito, que associam a música à poesia e a componentes cênicos.
} 
eles, Edgar Willens (1890-1978) e Carl Orff(1895-1982). Willens aprofundou as ideias trazidas por Dalcroze. Trabalhava também baseado no tonalismo, introduzindo, antes das improvisações melódicas, improvisações rítmicas. Também introduziu improvisações melódicas a duas vozes e improvisações atonais. Carl Orff sistematizou a improvisação segundo os modelos intervalares que ele considerava mais naturais, por meio da limitação do material musical. Ele retirava as plaquetas do xilofone deixando apenas as correspondentes aos intervalos trabalhados, para que o aluno não tivesse a preocupação de acertar ou errar e pudesse desenvolver sua criatividade. Maurice Martenot (1898-1980) também considerava a improvisação e a criação musical, peças fundamentais da sua proposta pedagógica, utilizando principalmente o jogo, considerado por ele como uma "estratégia metodológica para a integração entre corpo e alma que, em consequência, refletem um resultado musical satisfatório" (FIALHO, ARALDI, 2011, p. 160).

Já no século XXI, educadores como Murray Schafer (2011) e François Delalande (2001) desenvolveram com as práticas de criação muitas das suas concepções educacionais. Para Delalande (2001), a criação musical é um dos pilares da sua ideia de educação musical que está baseada em três frentes: explorar, expressar e criar. A improvisação e a composição são estratégias de igual importância para esse educador no que se refere à criação. Para Schafer (2011), a educação musical deveria se basear, a princípio, na qualidade de escuta do ambiente sonoro, e assim os alunos poderiam construir suas próprias criações musicais.

Atualmente a importância da improvisação para a construção do pensamento e da aprendizagem musical vem sendo apontada por diversos educadores. Chefa Alonso (2007), por exemplo, enumera alguns dos valores da improvisação enquanto estratégia pedagógica. Entre eles, estão a aprendizagem de novas formas de relações interpessoais baseadas na igualdade, o aprofundamento da relação com o instrumento, já que se exploram novas maneiras de tocar, a maior compreensão das composições musicais, além da necessidade da resolução de problemas que se apresentam como similares aos da vida cotidiana (ALONSO, 2007, p. 57). Alonso (2007), constata também que, apesar de sua importância e relevância para os processos de educação musical, a improvisação vem sendo deixada de lado na maioria das aulas de diferentes instrumentos, tendência que se repete em vários países.

Enquanto em todos os conservatórios ou universidades de música se pode aprender a compor, a improvisação livre é a grande ausência de quase todos os ensinos musicais, talvez com exceção dos países nórdicos. Os estímulos para explorar o instrumento, fora do que pede a partitura, não existem na maioria destes centros de ensino. Improvisar é uma prática musical que se considera, em muitos casos, própria das músicas populares, das músicas que, 
precisamente, não tem lugar nestes centros acadêmicos (ALONSO, 2007, p. 54 , tradução nossa $)^{9}$.

Wade Matthews (2012) completa a observação de Alonso (2007), constatando que o lugar notadamente inferior em que a improvisação é colocada em relação à composição, sendo excluída dos planos de ensino, faz parte de um "modelo eurocêntrico de pensamento musical" (MATTHEWS, 2012, p. 29). O autor ressalta que, em algumas culturas extraeuropeias, a habilidade da improvisação é mais valorizada do que a da composição.

No contexto latino-americano e brasileiro, a aplicação da improvisação enquanto recurso pedagógico foi ressaltada por Hans-Joachin Koellreutter (1997), e mais recentemente por Violeta Gainza (2009), Carlos Kater (2017), Maria Teresa Alencar de Brito (2003, 2011), Pedro Paulo Salles (2002), Rogério Costa (2016), entre outros educadores. Segundo tais educadores, a improvisação deve ser utilizada desde o princípio da educação, oferecendo ao aluno a liberdade de criação e escuta, enquanto esse internaliza diferentes conteúdos musicais.

Koellreutter, segundo Brito (2003), via a improvisação como um dos principais focos do seu trabalho. Os jogos de improvisação propostos por Koellreutter enfatizam também aspectos como a organização, a convivência, a disciplina e a colaboração entre pares, além de trabalhar aspectos da estética da música contemporânea. Violeta Gainza (2009) defende que a improvisação deve ser utilizada nas aulas de instrumento musical, desde o início da formação do aluno, enfatizando seus objetivos.

Os objetivos específicos da improvisação musical poderiam ser sintetizados da seguinte maneira: 1) A aproximação e tomada de contato com o instrumento (e por meio dele, com a música); 2) A aquisição dos elementos da linguagem musical; 3) $\mathrm{O}$ desenvolvimento da criatividade; 4) A consolidação da técnica instrumental. ${ }^{10}$ (GAINZA, 2009, p. 25, tradução nossa).

Pedro Paulo Salles (2002), acredita que por meio da criação (composição e improvisação), a criança desenvolve uma relação afetiva e intelectual com a música, construindo seu conhecimento musical. Para o autor, a criação propicia ao aluno a "condição

\footnotetext{
${ }^{9}$ Mientras que en todos los conservatorios o Universidades de música se puede aprender a componer, la improvisación libre es la gran ausente de casi todas las enseñanzas musicales, quizá con excepción de los países nórdicos. Los estímulos para explorar el instrumento, fuera de lo que pide la partitura, no existen en la mayoría de estos centros de enseñanza. Improvisar es una práctica musical que se considera, en muchos casos, propia de las músicas populares, de las músicas que precisamente no tienen cabida en estos centros académicos (ALONSO, 2007, p. 54).

${ }^{10}$ Los objetivos específicos de la improvisación musical podrían sintetizarse de la siguiente manera: 1) La aproximación y toma de contacto con el instrumento (y por su intermedio, con la música; 2) La aquisición de los elementos del lenguage musical; 3) El desarollo de la creatividad; 4) El afianzamiento de la técnica instrumental. (GAINZA, 2009, p. 25).
} 
de empregar sons para seus valores afetivos (como o gosto, o prazer estético, o sentimento musical) e intelectuais (a matemática e a geometria sensoriais) das estruturas musicais" (SALLES, 2002, p. 81). Salles acredita que através da autoexpressão, possibilitada pelas atividades de criação musical, se desenvolve o que chamamos de autoestima (SALLES, 2002, p. 86).

Para Maria Teresa Alencar de Brito (2003) "a improvisação deve ser entendida como uma ferramenta pedagógica importante, que acompanha todo o processo de educação musical" (BRITO, 2003, p. 152), que oportuniza aos educadores a observação e a análise das relações que os alunos estabelecem com os materiais sonoros (BRITO, 2003, p. 152). Carlos Kater (2017) também defende a improvisação como proposta para o ensino de música. Segundo Kater (2017), a improvisação enfatiza as explorações sonoras, as experimentações em geral, as situações abertas, de espontaneidade, de exposição e de risco. Para ele, tais momentos "passam a contemplar progressivamente atividades lúdicas com maior grau de imprecisão e indeterminação, nas quais os alunos são levados a se posicionar, argumentar e tomar decisões" (KATER, 2017, p. 158).

Rogério Costa (2016), avalia que a improvisação enquanto estratégia pedagógica pode ser usada para proporcionar a construção do conhecimento e de habilidades como a escuta, que são fundamentais e possibilitam a prática musical.

Assim é que a improvisação pode ser considerada como um recurso
significativo na medida em que pode ensejar, através da prática (empírica e
experimental), uma configuração gradativa das operações e estruturas
cerebrais que se interligam de maneira simultânea e que formam as bases para
o funcionamento, cada vez mais complexo, do pensamento musical. O músico
que está inserido numa prática de improvisação põe em ação o seu pensamento
musical (mente e corpo integrados) e percebe- num sentido amplo do termo-
o fluxo sonoro e os acontecimentos musicais dinâmicos em que se insere essa
prática (COSTA, 2016, p. 84).

A improvisação e a composição também foram incorporadas aos Parâmetros Curriculares Nacionais da área de Arte, que propondo "improvisações e composições dos próprios alunos baseadas nos elementos da linguagem musical, em atividades que valorizem seus processos pessoais, conexões com a sua própria localidade e suas identidades culturais" (BRASÍLIA, 2000, p. 78).

Influenciados pelas ideias desses educadores, outros pesquisadores e professores brasileiros vêm abordando e utilizando a prática da improvisação em diferentes contextos, publicando material didático, principalmente em forma de dissertações de mestrado e teses de doutorado em diferentes instituições universitárias. César Augusto Coelho Albino (2009), por 
exemplo, escreveu sua dissertação de mestrado versando sobre a importância do ensino da improvisação musical no desenvolvimento do intérprete. Em tal trabalho, o autor conceituou o que seria a improvisação, sua aplicação em diferentes contextos e especificamente no contexto educacional. Também compôs uma série de peças nas quais os estudantes participantes tiveram acesso a material relativo à improvisação livre.

Fábio Sardo (2012) pesquisou a utilização da improvisação enquanto estratégia para o ensino da guitarra flamenca. Nesse trabalho, o autor desenvolveu conteúdos da improvisação livre e da improvisação idiomática, presente no flamenco. Tal pesquisa partiu das necessidades do próprio autor em proporcionar um ensino mais efetivo desse instrumento.

Marcelo Mateus de Oliveira (2012) pesquisou a improvisação na iniciação coletiva no ensino do violão. O autor também partiu da sua experiência enquanto professor e das estratégias possíveis de serem utilizadas para o ensino coletivo do instrumento. Relaciona-se com as ideias de parâmetros e princípios de educação musical de Keith Swanwick.

André Campos Machado (2014) desenvolveu um trabalho com improvisação livre como metodologia para o ensino coletivo de cordas dedilhadas. A ideia do seu trabalho é que seria possível adquirir o domínio técnico do instrumento, habilidades de escuta e apreciação musical, aliado aos elementos criativos proporcionados pela improvisação livre. O autor elaborou um material didático que acompanha a dissertação, o qual pode ser utilizado por outros educadores que possuam as mesmas intenções.

Camila Costa Zanetta (2014) desenvolveu seu trabalho baseando-se em jogos cênicosmusicais para a educação musical de crianças. A autora utilizou uma série de jogos que foram aplicados em aulas de musicalização. Tais jogos eram estruturados sobre os modelos de Koellreutter e Viola Spolin.

Claudia Maradei Freixedas (2015) vem abordando a improvisação em aulas de flauta doce. A autora elaborou um trabalho baseado em jogos de escuta e criação, associado às linguagens e escrita da música contemporânea, englobando as técnicas estendidas para flauta doce. Para ela, é fundamental que os alunos participem das aulas de instrumento de uma maneira mais criativa e cativante, despertando o potencial artístico presente em cada um (FREIXEDAS, 2015, p. 12).

Os professores de violoncelo brasileiros também vêm, timidamente, apontando para a necessidade de processos criativos na aprendizagem do instrumento. Sanny Santos de Souza (1998) já traz em sua pesquisa a consideração da ausência de atividades de criação destinadas aos estudantes de violoncelo. Da mesma forma, Maria Salete de Carvalho (2010) alerta para a lacuna existente na pedagogia do violoncelo em relação à propostas que enfatizem a criação 
musical, mas não sendo esse o objetivo da sua pesquisa, não se debruça largamente sobre esse tema. Além dos trabalhos dessas duas pesquisadoras, não dispomos de trabalhos publicados no Brasil sobre o ensino do violoncelo que tragam à luz elementos como a composição e a improvisação. No trabalho de Meryelle Maciente (2008), a autora já relata a pouca informação existente a respeito de metodologias e abordagens didáticas sobre o ensino e aprendizagem do violoncelo.

Porém, destacam-se dois trabalhos realizados recentemente em Portugal, que enfatizam a importância da improvisação no ensino do violoncelo. Em um deles, o trabalho de José Pedro da Silva Souza (2014), o autor enfatiza a prática da improvisação livre com o objetivo de criar motivação para o estudo do instrumento. Adriana Amélia Pombal Dantas Esteves (2015), por sua vez, traz a improvisação como elemento para solucionar problemas de ordem técnica ao violoncelo.

O trabalho proposto por essa pesquisa se enquadra dentro do contexto educacional apresentado. Tem ressonâncias com o trabalho de Claudia Freixedas (2015), na medida em que se baseia e se apoia em jogos de improvisação elaborados pela educadora em sua abordagem com flautas doces. Também utiliza na elaboração dos jogos, material proveniente dos trabalhos de Violeta Gainza (2009) e dos relatos de Maria Teresa Alencar de Brito e Wanderson Cruz, durante a disciplina cursada e intitulada "Música e jogo, jogo musical, jogo ideal: tendências e proposições nos territórios da educação", em 2017.

Conforme citado anteriormente, algumas ideias e conceitos de jogo também foram revisados durante a pesquisa bibliográfica, no intuito de compreender como é feita, pelos pesquisadores, as associações entre os jogos e a improvisação. Brougère (1995), nos faz atentar para o fato de que o uso da ideia de jogo se constitui em uma noção aberta, polissêmica e, às vezes, ambígua (BROUGÈRE, 1995, p. 14). Kishimoto (2013) compartilha dessa visão, e segundo a autora, a polissemia da palavra jogo também gera confusão quanto aos seus objetivos e propostas dentro do contexto educacional (KISHIMOTO, 2013, p. 13). As diferentes ideias de jogo, trazidas pela revisão realizada durante essa pesquisa, não pretendem abordar todas as múltiplas concepções existentes sobre o jogo em distintas áreas do conhecimento, mas contemplar algumas dessas ideias, onde a relação entre jogo e arte é enfatizada.

O pensador Johan Huizinga (1872-1985) em Homo Ludens, que teve sua primeira edição em 1938, destina parte de seu livro a propor especificamente que o laço entre a música e o jogo é extremamente estreito, chegando a considerá-los sinônimos. O trabalho de Huizinga é tomado como referência para demais trabalhos que lidam com ideias de jogo, sendo que o autor procura esclarecer que sua análise aborda o jogo como fenômeno cultural. Huizinga 
esclarece também que, para ele, sua intenção "não era definir o lugar do jogo entre todas as outras manifestações culturais, e sim determinar até que ponto a própria cultura possui um caráter lúdico" (HUIZINGA, 2000, p. 2). Huizinga, ao destacar a relação entre música e jogo, enumera características que, segundo ele, definiriam o jogo, considerando que a música possuiria características similares ou paralelas a essas atividades.

Conforme dissemos, o jogo situa-se fora da sensatez da vida prática, nada tem a ver com a necessidade ou a utilidade, com o dever e com a verdade. Ora, tudo isto pode aplicar-se também a música. Além disso, as formas musicais são determinadas por valores que transcendem as ideias lógicas, que transcendem até nossas ideias sobre o visível e o tangível (HUIZINGA, 2000, p. 177).

Jean Chateau (1908-1990), psicólogo e pensador francês, relaciona diretamente a arte com o jogo infantil. Para Chateau (1987) existe diferença entre o jogo infantil e o jogo adulto. Segundo ele, "o jogo da criança tem seu fim em si mesmo, na afirmação do eu” (CHATEAU, 1897, p. 33). Para ele, a arte é a continuidade do jogo infantil na vida adulta, e estabelece as características que ambos possuem em comum. $\mathrm{O}$ autor assinala:

Se se quiser encontrar na vida adulta um equivalente do jogo infantil, sem
dúvida não será no jogo adulto que se deverá procurar, mas nas atividades a
um tempo gratuitas e sérias como o jogo infantil. Ao passo que o jogo adulto
carece de seriedade, porque é uma atividade secundária que tem seu objetivo
fora de si mesma, uma atividade como a arte, igualmente gratuita, pode
encontrar seu fim em si mesma, na expressão da personalidade do artista
(CHATEAU, 1987, p. 33).

O filósofo Gilles Deleuze (1925-1995) traz em 1969 o conceito de "jogo ideal", baseando-se na obra de Lewis Carroll (1832-1898), Alice no país das maravilhas (1865). Para Deleuze, o “jogo ideal” é o jogo no qual não existem vencedores e vencidos, que está acima da moralidade, um jogo inocente. Os ganhos estariam no próprio ato de jogar, sem causas e efeitos, cada lance carregando a sua própria regra e em que as jogadas seriam qualitativamente distintas. Ele descreve que "este jogo que não existe a não ser no pensamento, e que não tem outro resultado além das obras de arte, é também aquilo pelo que o pensamento e a arte são reais e perturbam a realidade, a moralidade e a economia do mundo" (DELEUZE, 2000, p. 63). Algumas ideias de Deleuze são também abordadas por Costa (2016), que acredita que a improvisação livre se aproxima da concepção de "jogo ideal”, conforme proposto pelo filósofo. Costa (2016) afirma que "o jogo da improvisação livre põe em ação a vontade criativa dos músicos, o desejo de atuar num ambiente pleno de virtualidades onde as matérias ainda não estão formadas" (COSTA, 2016, p. 83).

O filósofo Friedrich Nietzsche (1844-1900) é apontado pelos pesquisadores da sua obra 
como tendo trazido em diversos momentos a relação entre a arte e o jogo. Segundo Guervós (2011), Nietzsche enfoca essa relação sob vários aspectos, como por exemplo, em conceitos como a metafísica do artista e o "jogo estético" do vir-a-ser. Também estabelece a diferença entre o artista dionisíaco, baseado no jogo da embriaguez, e o artista apolíneo, baseado no jogo do sonho. Segundo o autor, "uma das raízes fundamentais da ideia do 'jogo' no jovem Nietzsche se encontra na referência que o filósofo faz à estrutura grega do agón e sua importância para o âmbito não apenas político, mas também artístico do povo grego ${ }^{11}$ " (GUERVÓS, 2011, p. 53).

Desde seus primeiros escritos, especialmente no contexto de sua "metafísica de artista", Nietzsche começa a articular suas ideias adotando, como referência, a misteriosa dimensão do jogo. Trata-se de uma ideia presente nos momentos principais do desenrolar de seu pensamento e talvez seja um desses elementos que, de maneira velada, oculta-se sob formas e figuras distintas, a fim de dizer de outra maneira o vir-a-ser, a vida ligeira, a arte; ou, em outras palavras, para pensar para além da metafísica (GUERVÓS, 2011, p. 72).

O também filósofo alemão Hans-George Gadamer (1900-2002), ao pensar a experiência da arte não mais como um comportamento de abstração, apoia-se nas ideias de jogo de Huizinga. O autor utiliza, com frequência, a expressão "modo de ser da obra de arte", afirmando que a arte somente ganha significado ao ser apresentada para alguém, incluindo o espectador nesse processo. Gadamer, em Verdade e Método, texto de 1960, afirma que "através de sua apresentação o jogo jogado interpela o espectador e de tal modo que este passa a ser parte integrante do objeto, apesar de todo o distanciamento de estar de frente para o espetáculo" (GADAMER, 1999, p. 172). Ao analisar a relação entre a arte e o jogo, Gadamer argumenta:

Quando em correlação com a experiência da arte, falamos de jogo, jogo não significa aqui o comportamento, e muito menos o estado de ânimo daquele que cria ou daquele que usufrui, e sobretudo, não significa a liberdade de uma subjetividade que atua no jogo, mas o próprio modo de ser da obra de arte (GADAMER, 1999, p. 174).

O educador, pesquisador e compositor François Delalande (2001) se apoia nas ideias de jogo de Jean Piaget (1896-1980) para estabelecer relações entre a música e o jogo. Piaget tem tido sua obra bastante referenciada pelos educadores musicais, sendo citada a sua "teoria do desenvolvimento cognitivo", estágios por onde os seres humanos passariam durante o seu desenvolvimento. Piaget considera os jogos fundamentais para os processos de aprendizagem, pois através do jogo a criança assimila novas informações, bem como acomoda essas informações em suas estruturas mentais (NEGRINE, 1994, p. 33). Piaget também distingue os jogos em três

\footnotetext{
${ }^{11}$ Agón é uma divindade grega que personificava os concursos, desafios e disputas solenes nos campos políticos, artísticos e atléticos.
} 
categorias: jogos de exercício ou sensório-motores, jogos simbólicos e jogos de regras.

Baseado nas ideias de Piaget, Delalande (2001) identifica a música como o próprio jogo. Para o autor, a música é a continuidade do jogo na vida adulta (DELALANDE, 2001, p. 20), sendo que ambos, música e jogo, mantém uma relação estreita também no plano pedagógico. Delalande associa as fases da aprendizagem propostas por Piaget com as fases da aprendizagem musical. Ao mesmo tempo, ele relaciona as características e maneiras de construção da música com as características do modelo dos jogos de Piaget. Ele sugere que em todas as músicas existem, em maior ou menor grau, os elementos das três fases do jogo apontadas por Piaget, transformando essas no seu pilar educativo. Para Delalande, a educação musical consiste em se preservar o caráter lúdico da música, por meio da exploração, da expressão e da criação.

Educar as crianças não é tirá-los de um estado de nada musical que se supõe que estão, para levá-los a um certo nível de competência, mas, pelo contrário, é desenvolver uma atividade lúdica que existe entre elas e que é, finalmente, a própria fonte do jogo, da execução musical. ${ }^{12}$ (DELALANDE 2001, p. 28, tradução nossa).

O educador Pedro Paulo Salles (2002) também relaciona os jogos musicais com algumas ideias de jogo propostas por Piaget. Ele explica que "os jogos sonoros aparecem quando a criança brinca com os sons, sem expectativas de resultados, porquanto estes são manipulados" (SALLES, 2002, p. 91). Sendo assim, o autor acredita que as formas de improvisação, sobretudo a improvisação individual, seriam a manifestação desse jogo primitivo. Os jogos simbólicos estariam presentes nas histórias sonoras e musicais e os jogos com regras se manifestam nas composições, na performance e nas improvisações guiadas por regras.

O educador musical Keith Swanwick (2006), assim como Delalande e Salles, se apoia em concepções de jogo de Jean Piaget para estabelecer a relação entre a arte e o jogo. O autor enfatiza que, enquanto o jogo tende a desaparecer na vida adulta, a arte permanece como manifestação das características lúdicas do domínio, da imitação e da criatividade. Tais conceitos, advindos da obra de Piaget, estabelecem o domínio como uma espécie de virtuosismo, que aparece nos jogos da primeira infância, ligam a imitação aos jogos imitativos e a criatividade aos jogos imaginativos.

As artes não tem grande semelhança com os sonhos, mas sim com o jogo. São as únicas atividades em que o domínio, a imitação e a imaginação podem fomentar e se ampliar deliberadamente na infância e depois dela, a diferença

\footnotetext{
${ }^{12}$ Educar a los niños no es sacarlos de un estado de nada musical en que se supondría que están, para llevarlos a un cierto nivel de competencia, sino, por el contrario, desarrollar una actividad lúdica que existe entre ellos y que es finalmente la fuente misma del juego, la ejecución musical. (DELALANDE, 2001, p. 28)
} 
do jogo propriamente dito, que tende a desaparecer. ${ }^{13}$ (SWANWICK, 2006, p. 57, tradução nossa).

A pesquisadora Arminda Aberastury (1972) enfoca o jogo musical sob a ótica da psicanálise, ressaltando sua importância para a formação do sujeito. Segundo a autora, ainda bebê, a criança escuta os sons que saem do seu próprio corpo e brinca com eles, tentando modificá-los e repeti-los. Mais tarde, o chocalho e o tambor vão ser representativos de diferentes tipos de jogos. Com o chocalho, a criança brinca de aparecer e desaparecer, no caso, os sons, e com o tambor ela revive o ventre da mãe, comunica-se e libera tendências agressivas (ABERASTURY, 1972, p. 42).

Completando esse trabalho de revisão da literatura, essa pesquisa investigou também algumas concepções do educador e filósofo norteamericano John Dewey (1895-1952) sobre educação, arte e experiência, em consonância com o pensamento do espanhol Jorge Larrosa Bondía. As concepções desses autores, em muito dialogam com as de pesquisadores que tratam sobre o tema da improvisação, como Matthews (2012), Alonso (2007), Delalande (2001) e Kater (2017). Sendo assim, ao revisar tais concepções e trazê-las para o trabalho, foram estabelecidos alguns paralelos entre elas, que refletem o caráter vivencial e experimental da improvisação, tanto enquanto proposta artística, como educacional.

A literatura aponta que Dewey destinava à arte um papel fundamental na vida do ser humano e dedicava reflexões a respeito de sua natureza e significado, como mostra o texto trazido por Ana Mae Barbosa em John Dewey e o ensino da arte no Brasil (2001).

\begin{abstract}
A arte não é um produto exterior nem um comportamento externo. É uma atitude do espírito, um estado da mente-aquele que exige para sua própria satisfação e realização na formulação de questionamentos uma forma nova e mais significativa. Perceber o significado do que se está fazendo e se regozijar com ele, unificar, simultaneamente em um mesmo fato, o desdobramento da vida emocional interna e o desenvolvimento ordenado das condições externas materiais- isso é arte (DEWEY, 2001, p. 30).
\end{abstract}

Dewey, em obras como Arte como experiência (2010) e Experiência e educação (2011), toma o termo e a ideia de experiência como base da sua proposta de educação. Nas considerações apresentadas por Dewey (2010 e 2011), o autor enfatiza que só se aprende por meio de experiências significativas, em que a qualidade das experiências é o que define seu significado. Dewey considera a arte como uma forma de experiência singular, colocando-a,

\footnotetext{
${ }^{13}$ Las artes no tienen gran similitud con los sueños, pero sí com el juego. Son las únicas actividades en las que el dominio, la imitación y la imaginación se pueden fomentar y ampliar deliberadamente en la infancia y después de ella, a diferencia del juego propriamente dicho, que tiende a desaparecer.
} 
assim, como importante estratégia para a aprendizagem. O autor sinaliza que, tanto a arte quanto a experiência, possuem um caráter estético, e que "toda obra de arte segue o plano e o padrão de uma experiência completa, fazendo que ela seja sentida de maneira mais intensa e concentrada" (DEWEY, 2010, p. 134). Segundo a compreensão de Dewey, o artista carrega em si, simultaneamente, tanto as características da produção de um objeto artístico, quanto as de apreciação desse objeto, incorporando, ao trabalhar, a atitude do espectador (DEWEY, 2010, p. 128). As experiências capazes de agregar conhecimento necessitam que estejam presentes em si, o mesmo caráter estético presente nas obras de arte.

Os trabalhos de Alonso (2007), Delalande (2001), Swanwick (2006) e Gainza (2009) apontam que a prática da improvisação enquanto recurso pedagógico propicia aos sujeitos envolvidos a experimentação dos conteúdos musicais. Para isso, necessitam da presença e da participação do sujeito de forma plena e ativa, possuindo, por este ponto de vista, as características de uma experiência singular conforme proposto por Dewey, capazes de agregar conhecimento. Assim como abordado por autores como Fonterrada (2008) e Swanwick (2006), com a ausência de atividades de criação nas aulas de instrumento, essas correm o risco de se transformarem em um processo mecânico de transmissão oral de informações. A inclusão de atividades relacionadas à criação, segundo os autores mencionados, possibilita a incorporação dos conteúdos musicais e a expressão individual e artística dos alunos.

O pensador espanhol Jorge Larrosa Bondía (2002) dialoga com as ideias desses educadores, ao mesmo tempo em que está em consonância com as concepções de Dewey, quando propõe que pensemos a educação a partir do par experiência/sentido. Larrosa considera que "a informação não é experiência” (LARROSA, 2002, p. 21). Para Larrosa "a informação não deixa lugar para a experiência, ela é quase o contrário da experiência, quase uma antiexperiência" (LARROSA, 2002, p. 21). As atividades de improvisação musical, assim como destaca Gainza (2009), também não têm como objetivo apresentar conteúdos de forma sistemática ou informativa, e sim, possibilitar o vivenciar de experiências musicais que vão se incorporar ao repertório dos sujeitos.

Para Dewey (2010), em uma experiência singular, todo o processo envolvido em sua constituição é catalisador e agregador de conhecimento e não apenas o seu resultado final. Matthews (2012) destaca semelhante processo em relação às práticas de improvisação. $\mathrm{O}$ autor aborda que uma das diferenças entre a improvisação e a composição é a ênfase no processo de criação ou no produto resultante desse processo, destacando que, na improvisação não há produto posterior, nem dissociável de seu processo de criação, proposta semelhante às concepções de Dewey (2010) em relação à experiência. 
O educador Carlos Kater (2017) traz algumas ideias que podem ser consideradas consonantes com a concepção de Dewey em relação à construção do conhecimento através do ato criativo, profundamente envolvido nas práticas musicais como a composição e a improvisação. Kater (2017) aborda que, através do ato criativo, existe a possibilidade de se agregar, além do conhecimento sobre o objeto ou situação envolvida, o conhecimento sobre si mesmo.

Todo ato criativo é uma resposta dinâmica que damos a algo, a algum desafio ou questão, nem sempre claramente formulados. Criar é, nesse sentido, também uma oportunidade de ampliar o "eu consciente". Quando uma criança percebe o sentido daquilo que faz musicalmente, é a sua própria vida que se preenche de sentido e a profundidade que há nisso se evidencia quando nos lembramos de que - como adultos e não apenas como crianças - nós só existimos realmente no tempo presente, tempo que se abre, aprofunda e expande quando estamos mergulhados na experiência criativa (KATER, 2017, p. 161).

Ao concluir o trabalho de revisão da bibliografia, mergulhado nas concepções de Dewey (2010) e Kater (2017), destaco a abordagem de Ana Mae Barbosa (2001), que ao dedicar-se ao estudo das obras de Dewey e sua influência na educação brasileira, constata que, de maneira contrária ao que propunha esse autor, a arte vem sendo, ainda hoje, tratada como uma espécie de decoração ideológica das escolas, relacionada, segundo a autora, ao problema de dependência (BARBOSA, 2001, p. 52). Chefa Alonso (2007), assim como autores como Matthews (2012) e Costa (2016), propõe, em contrapartida, que as práticas de improvisação e sua adoção enquanto estratégia pedagógica, podem se posicionar na margem oposta a essa tendência, promovendo, além de possibilidades de criação e autonomia artística, um espaço de identificação contra os sistemas de hierarquia e de controle, trazendo a arte para um patamar democrático e inclusivo, assim como idealizava Dewey (2010 e 2011).

Partindo desse trabalho de revisão da bibliografia, ideias e concepções sobre jogos de improvisação se desenvolveram no decorrer da elaboração da presente pesquisa, levando-se em consideração distintas perspectivas, a fim de se propor atividades compatíveis com a compreensão possibilitada pelas concepções dos autores abordados. Por serem desenvolvidas no patamar da inclusão e da coletividade, foram contempladas também, na revisão da literatura, as propostas de ensino coletivo, que fizeram parte da estruturação e configuração dos jogos de improvisação adotados.

\subsection{O ENSINO COLETIVO DE INSTRUMENTO}

$\mathrm{Na}$ literatura referente ao ensino de instrumentos musicais é apontado que as práticas 
de ensino coletivo possuem algumas características particulares. Segundo Cruvinel (2003), pode-se categorizar os modelos de ensino de instrumento musical de duas maneiras: o ensino tutorial e o ensino coletivo (CRUVINEL, 2003, s/p). Segundo a autora, o ensino tutorial também é chamado algumas vezes de "modelo conservatorial". Tal denominação se dá por ser essa a maneira de ensino predominante nos conservatórios e escolas especializadas de música. De acordo com Cruvinel (2003), o ensino tutorial originou-se no fim do século XVIII com o surgimento do Conservatório de Paris, já o ensino coletivo, teria se originado no século XIX, na Inglaterra, tendo, posteriormente, estabelecido-se nos Estados Unidos.

Társila Castro Rodrigues (2012) contextualiza o surgimento do modelo coletivo de ensino nos Estados Unidos, afirmando que esse influenciou perspectivas em outros países. Segundo Rodrigues (2012) "nas primeiras décadas do século XIX, nos Estados Unidos, o modelo de ensino coletivo iniciou com bastante força, ao mesmo tempo que suas fases históricas influenciavam-se por iniciativas provenientes de outros países" (RODRIGUES, 2012, p. 21). Oliveira (1998) destaca três fases do ensino coletivo nesse país: a fase das academias, a fase dos conservatórios e a fase das escolas públicas (OLIVEIRA, 1998, p. 9). A fase das academias teria sido incentivada por motivos econômicos, a fase dos conservatórios foi influenciada pela inauguração do Conservatório de Leipzig na Alemanha, por Felix Mendelssohn. Antes da terceira fase houve uma lacuna, com o desaparecimento do ensino coletivo no final do século XIX, que só foi preenchida no início do século XX, com a influência do movimento ocorrido na Inglaterra, chamado The maidstone movement, trazido para os Estados Unidos em 1911 pelo inglês Albert Mitchell. Também é destacado por Montandom (1992) a importância do surgimento de aulas coletivas de piano, referenciando o trabalho do alemão Johann Bernhard Logier, professor de piano na Cidade de Dublin, por volta de 1815, que influenciou professores norteamericanos e europeus (MONTANDOM, 1992, p. 8).

$\mathrm{Na}$ área específica das cordas friccionadas, Oliveira (1998) afirma que em 1851 foi editado o primeiro método de ensino coletivo de instrumentos de cordas, o The Musical Academy: for violin, bass-viol(cello), clarinete, flute and other light instruments, elaborado por Lewis Benjamin. $\mathrm{O}$ autor considera que a prática da música religiosa, que era essencialmente vocal, influenciou o surgimento do ensino coletivo de cordas friccionadas. Segundo o autor, os professores de música coral, que estavam aptos a ensinar também instrumentos de cordas, "puderam, a partir da sua prática coletiva, desenvolver metodologias específicas, modificando, apenas, as estratégias necessárias" (OLIVEIRA, 1998, p. 2).

Segundo os pesquisadores, algumas características diferenciam o modelo de ensino tutorial do modelo coletivo. No ensino tutorial, as aulas de instrumento são ministradas 
individualmente e acompanham o ritmo de aprendizagem do aluno, dependendo de suas habilidades e tempo de estudo realizado em casa para vencer os desafios propostos pelo professor, relacionados ao trabalho técnico e musical de exercícios e repertório apropriados para a fase em que o aluno se encontra. Basicamente, o aluno dita o seu próprio ritmo de aprendizagem. O mais comum no Brasil é que esse modelo de ensino ocorra em aulas de 50 minutos a uma hora, uma vez por semana. Segundo Abel Moraes (1997), no ensino individual “o professor é fonte única do conhecimento, o aluno é um receptor das informações e possui uma participação quase sempre passiva, cabendo a ele um papel mais imitativo do que reflexivo" (MORAES, 1997, p. 72).

No ensino coletivo, as aulas são ministradas para grupos de alunos e essas aulas podem ocorrer de diferentes maneiras, geralmente em períodos de uma hora e meia a duas horas, variando entre uma, duas ou mais vezes na semana. Uma das formas de caracterização do ensino coletivo acontece pela especificidade do instrumento. Quando o ensino coletivo se dá de maneira em que vários instrumentos são ensinados ao mesmo tempo durante a aula, esse ensino se caracteriza como "ensino heterogêneo" e quando apenas um instrumento é ensinado para todos os alunos se caracteriza como "ensino homogêneo" (CRUVINEL, 2003, s/p).

No Brasil, a prática do ensino coletivo de instrumentos musicais teria iniciado, segundo os pesquisadores, na segunda metade do século XX. Frequentemente o nome de VillaLobos e a prática do canto orfeônico são associados ao estímulo desse modelo de ensino. Segundo os levantamentos de Cruvinel (2003) e de Oliveira (1998), a proposta do ensino coletivo foi inicialmente aplicada por José Coelho de Almeida, que utilizou essa metodologia em bandas do interior do estado de São Paulo. Nos anos setenta do século XX foram também pioneiros os trabalhos com cordas friccionadas realizados por Alberto Jaffé e Daisy de Luca, também em São Paulo. Na década de oitenta do mesmo século, segundo Oliveira (1998), o professor José Coelho de Almeida também implantou o ensino coletivo dos instrumentos de cordas friccionadas no Conservatório Estadual Dr. Carlos de Campos, em Tatuí, interior do estado de São Paulo, onde era diretor. O trabalho de Alberto Jaffé e Daisy de Luca tem recebido notável destaque, como se pode observar nas colocações de Oliveira (1998):

O trabalho de Alberto e Daisy Jaffé foi, sem dúvida, o mais importante para a história dos métodos coletivos de cordas no Brasil, pois além de eles serem os pioneiros, contribuíram, ainda, para a formação da maioria de profissionais de cordas existente no país. Nos Estados Unidos já existem 30 diferentes grupos que utilizam seu método, o que significa um número aproximado de 1000 alunos aprendendo através do Jaffé String Program (OLIVEIRA, 1998, p. 13). 
possui diferentes concepções e propostas. Segundo a autora, as mais frequentes são a formação musical (iniciação musical), a formação instrumental (iniciação instrumental), a formação humanística (formação integral do ser humano) e a formação social (democratização do ensino musical). Em alguns casos, essas diferentes concepções atuam simultaneamente, como complementares de uma mesma abordagem.

Também se destaca entre os pesquisadores a ideia de que o ensino coletivo não deve ser uma cópia do modelo de ensino tutorial, apenas aplicado a mais de uma pessoa ao mesmo tempo. Galindo afirma que "a simples transposição de técnicas utilizadas em aulas individuais para o ensino em grupo certamente não produzirá resultados positivos” (GALINDO, 2000, p. 46).

Para Abel Moraes, "a grande maioria dos professores de instrumento musical adota a forma individual de ensino unicamente, devido à forte tradição que nos foi legada" (MORAES, 1997, p. 70). Ainda persiste na maioria das aulas de instrumento a ideia de que a forma de aprendizagem mais efetiva é por meio da atenção exclusiva. Contrapõe-se a ela a "crença do ensino coletivo, de que é possível compartilhar conhecimento, espaço, e que a interação e a diferença são partes importantes do aprendizado" (TOURINHO, 2007, p. 1). Tourinho observa ainda:

\begin{abstract}
A concepção de ensino coletivo está aqui conceituada como transposição inata de comportamento humano de observação e imitação para o aprendizado musical. Professores de ensino coletivo levam em consideração o aprendizado dos autodidatas, que se concentram inicialmente em observar o que desejam imitar (TOURINHO, 2007, p. 2).
\end{abstract}

Segundo levantamento realizado por Tourinho (2007), seis princípios básicos são aplicados pelos professores de ensino coletivo no Brasil:

1) Todos podem aprender a tocar um instrumento;

2) Todos aprendem com todos;

3) A aula é direcionada para todo o grupo;

4) A aula é planejada para o grupo;

5) A aula desenvolve autonomia e decisão;

6) O ensino coletivo elimina os horários vagos (TOURINHO, 2007, p. 2).

Foi observado também pelos pesquisadores citados, que a grande maioria dos professores brasileiros considera que o ensino coletivo de um instrumento musical se adequa melhor à fase de iniciação, sendo necessário que o aluno procure uma orientação tutorial após 
alguns semestres de estudo, como podemos observar nas colocações de Galindo (2000):

O ensino em grupo tem como limitação o seu tempo de aplicação: se é indicado com vantagens ao início do aprendizado deve ser abandonado depois que todos os itens da técnica básica do instrumento forem transmitidos. A partir daí o ensino individual deve tomar seu lugar (GALINDO, 2000, p. 59).

Porém, os mesmos pesquisadores relatam que tal crença vem sendo desfeita por trabalhos desenvolvidos por professores universitários, como por exemplo, Mario Ulloa (violão), Jorge Sacramento (percussão) e Abel Moraes (violoncelo). Os pesquisadores destacam ainda que a formação e a atuação de um professor de instrumento em ensino coletivo deve ser enriquecida com alguns elementos importantes, como o carisma, a habilidade de dar atenção a todos os indivíduos do grupo ao mesmo tempo, a habilidade de fazer correções de maneira subjetiva, como por exemplo, um olhar ou um sorriso. Abel Moraes (1997) ressalta também que "são necessários conhecimentos e experiência nas três áreas pedagógicas básicas envolvidas no ensino em grupo: musical, instrumental e psicológica educacional" (MORAES, 1997, p. 74). O professor atua mais como um facilitador, que orienta o desenvolvimento das atividades, proporcionando uma aprendizagem colaborativa.

Moraes (1997) destaca ainda os objetivos principais da proposta de ensino em grupo. Tais objetivos são de ordem cognitiva, afetiva, técnica ou psicomotora e psicológica e social. Como objetivos cognitivos o autor destaca o desenvolvimento da percepção e da consciência dos elementos musicais básicos relacionados ao instrumento, a concentração, os conhecimentos históricos e os conhecimentos dos princípios técnicos do instrumento. De ordem afetiva são ressaltados o desenvolvimento de atitudes positivas em relação à música e de uma resposta intuitiva do aluno aos conteúdos musicais propostos. Como objetivos técnicos, o autor destaca o desenvolvimento de proficiência técnica para atender aos requerimentos musicais das peças estudadas e na área psicológica e social, o fortalecimento da autoestima e da autoimagem, da autoconfiança e da confiança nos outros.

Além dos pesquisadores citados também foram abordados durante a pesquisa bibliográfica outros trabalhos relacionados a prática do ensino coletivo de cordas friccionadas no Brasil, como por exemplo, os trabalhos de Tais Dantas (2016) e Liu Man Ying (2011). Dantas (2016) analisa o ensino coletivo de cordas friccionadas segundo experiência realizada no Programa de Extensão Ensino Coletivo de Instrumentos Musicais da Universidade Estadual de Feira de Santana, procurando descrever, através dessa experiência, a importância da construção de exercícios técnicos e de arranjos para o desenvolvimento da motivação dos alunos para a aprendizagem, ao mesmo tempo em que propõe a construção de um repertório 
sequencial com propostas didáticas. Ying (2011) propõe uma metodologia direcionada à iniciação ao violino, através do ensino coletivo, baseada em melodias folclóricas extraídas do primeiro volume do Guia Prático do Canto Orfeônico (1941). elaborado por Heitor VillaLobos.

Delalande (2001), propõe ainda a prática do ensino coletivo sob outra perspectiva. O autor considera que essa deve ser incentivada e valorizada pois, segundo ele, a música é uma das poucas formas onde a criação artística pode acontecer em grupo, diferenciando-se, por exemplo, das artes plásticas (DELALANDE, 2001, p. 145). Ao comparar as duas áreas, Delalande considera que nas artes plásticas é possível que cada aluno, por exemplo, pinte uma parte de um quadro, sendo que o produto final será um somatório de diferentes partes. $\mathrm{Na}$ música, segundo o autor, a criação coletiva envolve todos os participantes de forma integral, todos os participantes estão presentes em todos os momentos. Para Delalande (2001), essa é uma importante estratégia para desenvolvermos o espírito colaborativo e a integração entre os sujeitos e uma perspectiva que enfatiza a adoção de práticas de criação dentro do ensino coletivo. 


\section{BASES TEÓRICO-METODOLÓGICAS DA PESQUISA}

Neste terceiro capítulo, trago os elementos teórico-metodológicos que serviram de base para todas as fases do processo de construção dessa pesquisa. Apresento inicialmente a identificação da abordagem escolhida para a investigação, a qualitativa, juntamente com o método, a pesquisa-ação, que se mostrou o mais adequado para alcançar o objetivo geral proposto. Apresento também os procedimentos e técnicas de coleta, organização e análise de dados adotados, indicando o que cada recurso me permitiu realizar antes, durante e após minha inserção no campo empírico. Por fim, trato dos princípios ético-metodológicos que orientaram a minha conduta em todas as etapas desse estudo.

\subsection{A ESCOLHA DA ABORDAGEM E DO MÉTODO}

Esse estudo está ancorado nos princípios norteadores da abordagem qualitativa de pesquisa. A fim de definir tal abordagem, Bogdan e Biklen (1994) enumeram suas cinco principais características. Segundo os autores, tais atributos podem aparecer em maior ou menor intensidade em diferentes trabalhos e até mesmo estarem ausentes em alguns casos, sem comprometer a caracterização da pesquisa. Os atributos citados pelos autores são: a fonte de coleta de dados é o ambiente natural e o pesquisador, por sua parte, constitui-se no principal instrumento de pesquisa, a investigação é descritiva, os investigadores se interessam mais pelo processo da pesquisa do que pelos resultados ou produtos obtidos, os investigadores tendem a analisar os dados coletados de forma intuitiva, e o significado do trabalho é de importância vital nesse tipo de pesquisa (BOGDAN, BIKLEN, 1994, p. 47).

As pesquisas qualitativas podem ser de várias ordens. Entre elas, destacam-se a pesquisa participante, o estudo de caso e a pesquisa-ação. Esse trabalho foi elaborado dentro dos princípios da pesquisa-ação. Em tal modalidade de pesquisa, considerada como uma pesquisa social, existe a intervenção do pesquisador durante a prática, que se associa com a resolução de um problema no qual o campo empírico está envolvido. Sendo assim, esse trabalho visa, com a minha intervenção enquanto pesquisadora, criar alternativas possíveis para a implementação da prática da improvisação no ensino coletivo do violoncelo.

A pesquisa-ação é um tipo de pesquisa social com base empírica que é concebida e realizada em estreita associação com uma ação ou com a resolução de um problema coletivo e no qual os pesquisadores e os participantes representativos da situação ou do problema estão envolvidos de modo cooperativo ou participativo (THIOLLENT, 2005, p. 16). 
Para David Tripp (2005), um dos setores onde a pesquisa-ação é aplicada é o campo educacional. O autor estabelece, inclusive, um subcampo, que ele denomina de "pesquisa-ação educacional" (TRIPP, 2005, p. 445). Para Tripp (2005), essa é uma estratégia para o desenvolvimento de professores e pesquisadores, pois tais profissionais poderiam utilizar as bases e resultados das pesquisas para realizar um aprimoramento do seu ensino e da aprendizagem dos seus alunos (TRIPP, 2005, p. 445). Nesse sentido, creio que o presente trabalho dialoga com tais princípios, pois busca desenvolver algumas práticas destinadas ao aprimoramento do ensino e aprendizagem do violoncelo.

\subsection{A PESQUISA-AÇÃO E SUAS ETAPAS}

Segundo Antonio Carlos Gil (1989), as fases da pesquisa-ação se intercalam e se complementam a todo o momento, sendo difícil distingui-las especificamente (GIL, 1989, p. 126). Para o autor, essas fases estão relacionadas com a "dinâmica do relacionamento dos pesquisadores em relação com a situação pesquisada" (GIL, 1989, p. 126). Michel Thiollent (2009) concorda com Gil ao afirmar que as fases da pesquisa-ação não são rigidamente ordenadas, elas adaptam-se às circunstâncias em que a pesquisa estiver inserida (THIOLLENT, 2009, p. 51).

As etapas da pesquisa-ação, segundo Gil (1989), são nove. Configuram-se como fase exploratória, exploração do problema, construção de hipóteses, realização do seminário, seleção da amostra, coleta de dados, análise e interpretação dos dados, elaboração do plano de ação e divulgação dos resultados (GIL, 1989, p. 126). A seguir, explico brevemente o que vem a ser cada uma das fases, segundo Gil, e associo cada fase com o trabalho realizado durante essa pesquisa.

A primeira fase da pesquisa-ação, denominada fase exploratória, tem como objetivo, segundo o autor, determinar o campo exploratório, as expectativas dos interessados e o tipo de auxílio que esses poderão oferecer ao longo do processo (GIL, 1989, p. 127). É o momento em que o pesquisador conhece o campo onde a pesquisa será realizada, entrando também em contato com os representantes dos sujeitos envolvidos.

A segunda fase da pesquisa-ação, segundo Gil, é a elaboração do problema a ser pesquisado. O autor explica que "sem este objetivo de solucionar problemas práticos, a pesquisa-ação não teria sentido, já que seria difícil conseguir a participação dos interessados" (GIL, 1989, p. 127). Thiollent (2008) denomina como "tema da pesquisa" a designação do problema prático e da área de conhecimento a serem abordados (THIOLLENT, 2008, p. 55). 
A terceira fase da pesquisa-ação é a construção de hipóteses para solucionar o problema pesquisado. Para Thiollent (2008), "uma hipótese é simplesmente definida como suposição formulada pelo pesquisador a respeito de possíveis soluções a um problema colocado na pesquisa, principalmente ao nível operacional” (THIOLLENT, 2008, p. 61). Para o autor, a elaboração da hipótese é importante porque assim o pesquisador evita a dispersão e focaliza determinados segmentos do campo de observação, entre outros fatores.

A próxima fase do trabalho da pesquisa-ação, segundo Gil (1989), é a organização do seminário. $\mathrm{O}$ autor esclarece que "este reúne os principais membros da equipe de pesquisadores e membros significativos dos grupos interessados na pesquisa" (GIL, 1989, p. 127), a fim de elaborar as diretrizes da pesquisa e da ação.

A quinta fase é denominada por Gil (1989) de fase de seleção da amostragem que participará da pesquisa. Segundo ele, "uma amostragem intencional, em que os indivíduos são selecionados a partir de certas características tidas como relevantes pelos pesquisadores e participantes, mostra-se mais adequada para a obtenção de dados de natureza qualitativa, o que é o caso de pesquisa-ação" (GIL, 1989, p. 128).

A próxima fase, a sexta, é a coleta dos dados, e se caracteriza como permitindo a adoção de procedimentos flexíveis. Segundo Gil (1989), as formas mais usuais são a entrevista coletiva ou individual, o questionário, a observação participante, a história de vida, a análise de conteúdo e o sociodrama (GIL, 1989, p. 128).

A sétima fase é a análise e interpretação dos dados coletados, e segundo Gil (1989), essa fase é bastante controversa. Algumas vezes essa interpretação se aproxima da interpretação da pesquisa clássica e em outras é resultante das discussões dos pesquisadores, elaborada com base nos dados obtidos empiricamente (GIL, 1989, p. 128).

A próxima fase da pesquisa-ação se constitui na elaboração de um plano de ação, destinado a enfrentar o problema que foi objeto de investigação. A última fase é a divulgação dos resultados de pesquisa. Segundo Gil (1989), essa fase se confunde com a fase anterior e pode ser feita por intermédio de congressos, conferências, simpósios, meios de comunicação de massa ou por meio de relatórios formais (GIL, 1989, p. 128).

A partir desses resultados, é esperado também que as atividades subsequentes sejam impactadas positivamente pela avaliação das experiências anteriores, nas quais, possivelmente, dificuldades foram encontradas, bem como possibilidades de otimização de estratégias foram construídas. Sendo assim, as etapas da pesquisa-ação, portanto, podem ser estruturadas em três grupos principais que se retroalimentam: o planejamento da proposta de intervenção, a implementação da proposta e a avaliação da proposta (Figura 1). 
Figura 1- Ciclo das etapas da pesquisa-ação

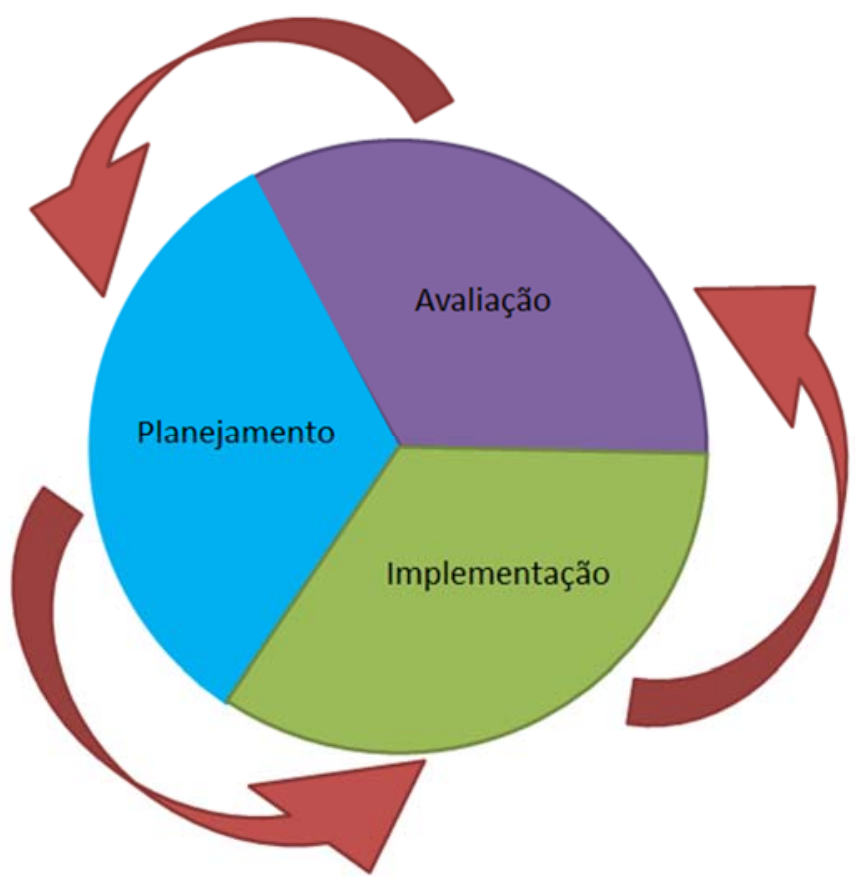

Fonte: Gil (1989), adaptado pela autora

No processo desse trabalho, a fase exploratória foi determinada pela escolha das três instituições de ensino onde a pesquisa de campo seria realizada, respectivamente, Instituto Baccarelli, Projeto Guri-Polo de Indaiatuba e Instituto Fukuda. Como mencionado anteriormente, tal escolha foi determinada pelas características comuns ao perfil de todas elas e comuns às instituições em que eu atuava enquanto docente na cidade de Porto Alegre, sendo elas, a oferta de aulas de instrumento de maneira coletiva e a ausência de aulas específicas de musicalização para os alunos que frequentam as aulas de instrumento. Após a escolha das instituições, foi feito o primeiro contato com seus representantes, a fim de verificar a disponibilidade da participação na pesquisa.

Em cada uma das instituições de ensino esse contato ocorreu por etapas. No Instituto Baccarelli foi feito um contato inicial com a diretoria da instituição, por e-mail, e posteriormente foram realizadas duas reuniões presenciais, a fim de estabelecer princípios e diretrizes para a realização da pesquisa. Uma das reuniões ocorreu com o diretor da instituição e outra com o professor de violoncelo e o coordenador pedagógico. Num momento posterior, também foi possibilitado que eu pudesse participar como ouvinte de uma aula das alunas que seriam as participantes da pesquisa, a fim de conhecer o grupo e o processo de ensino que estava sendo realizado junto a ele. No Projeto Guri-Polo de Indaiatuba, o primeiro contato também ocorreu por e-mail, inicialmente com a Diretora Educacional do projeto e, posteriormente, com 
a supervisora de cordas friccionadas da Regional de Jundiaí. Tal contato gerou uma aproximação com as atividades realizadas na instituição, sendo transmitidas diversas informações sobre o processo de ensino desenvolvido com os alunos envolvidos na pesquisa. Porém, não houve um momento de contato anterior com os alunos e professores, da maneira como ocorreu no Instituto Baccarelli. Da mesma forma, no Instituto Fukuda, o contato se deu em primeiro lugar por e-mail e posteriormente presencialmente na instituição, com seus diretores e com os professores da área de violoncelo. Nesse contato, foram sanadas dúvidas sobre o funcionamento da pesquisa e das aulas regulares da instituição. Assim como no Projeto Guri, não houve um momento prévio para o contato com os alunos que participariam da pesquisa, pois esses eram originários de diferentes turmas e professores da instituição.

A delimitação do problema de pesquisa girou em torno da falta de material pedagógico relacionado à prática da improvisação no ensino coletivo do violoncelo, com o objetivo do desenvolvimento da criatividade dos sujeitos e a aproximação com as poéticas da música contemporânea. A hipótese proposta pelo trabalho foi a realização de modelos de jogos de improvisação coletiva, trabalhando conceitos musicais e estéticos relacionados com a música da atualidade. Tais jogos foram baseados em jogos já testados por distintos educadores para outros grupos instrumentais ou educandos.

Durante a pesquisa não foram organizadas reuniões ou seminários específicos com os participantes, em função da dinâmica de ensino de cada instituição. Houve um encontro posterior com os professores, a fim de realizarmos uma entrevista. Nesse encontro, foram relatadas pelos professores suas ideias e percepções, bem como percepções trazidas pelos alunos em sala de aula em momento posterior à aplicação da pesquisa.

A amostragem foi selecionada segundo os critérios de cada uma das instituições participantes em relação às características relatadas como adequadas a atender os objetivos da pesquisa. Cada instituição selecionou dentro do seu contingente de alunos, os que, segundo ela, mais se adequavam ao perfil solicitado para a realização do trabalho. Dessa forma, foi possível a seleção de alunos com perfis e faixas etárias diversas, o que enriqueceu o processo de coleta de dados.

A minha inserção em campo aconteceu em três momentos distintos durante o segundo semestre do ano de 2017. Tal inserção ocorreu enquanto ministrante de aulas coletivas de violoncelo nas quais foram aplicados alguns dos modelos dos jogos de improvisação selecionados previamente. O número de aulas, bem como a sua duração, variou conforme as características e disponibilidades de cada uma das instituições. Durante as aulas, foram observadas as reações dos alunos em relação ao material proposto, sendo que, logo após a 
realização de cada aula, as minhas impressões eram registradas num Diário de Campo. Ao final de cada aula, era solicitado aos alunos participantes que escrevessem suas opiniões, impressões ou sensações a respeito dos jogos realizados. Ao final do trabalho como um todo, foi solicitado que os alunos respondessem individualmente a um questionário.

A pesquisa de campo no Instituto Baccarelli ocorreu no mês de setembro de 2017, em dez encontros de quarenta e cinco minutos, em que foram experimentados sete modelos dos jogos de improvisação selecionados previamente. Antes de participarem dos jogos de improvisação, as alunas, no total de nove, entre oito e quatorze anos, participavam de uma aula tradicional, também de quarenta e cinco minutos de duração com o professor do Instituto.

A pesquisa de campo no Projeto Guri-Polo de Indaiatuba ocorreu nos dias 24 e 26 de outubro de 2017, no formato de dois workshops de improvisação, com duas horas de duração cada um, nos quais foram desenvolvidos, no total, seis jogos de improvisação. No primeiro encontro, compareceram nove alunos, da faixa etária entre doze e dezoito anos, e no segundo encontro, compareceram doze alunos, da mesma faixa etária. Esses alunos tinham diferentes níveis de estudo no violoncelo, desde iniciantes até intermediários. Nos encontros realizados, estavam presentes alunos dos polos de Indaiatuba, de Monte Mor, e alguns alunos pertencentes ao Centro Suzuki Indaiatuba. Tais alunos foram convidados pela supervisora para que se juntassem aos alunos do Projeto Guri nas atividades desenvolvidas durante os workshops de improvisação. Além dos alunos de violoncelo, havia um aluno de contrabaixo, pois, como já foi citado, no Projeto Guri, as aulas de violoncelo ocorrem em conjunto com as aulas de contrabaixo.

A pesquisa de campo no Instituto Fukuda, assim como no Projeto Guri-Polo de Indaiatuba, ocorreu em dois encontros de duas horas de duração, denominados workshops de improvisação, nos quais também foram desenvolvidos seis jogos de improvisação. Tais encontros se realizaram nos dias 9 e 23 de novembro de 2017. O grupo selecionado para participar dos encontros foi um grupo bastante heterogêneo, contava com crianças das faixas etárias de sete a dez anos e com adultos, alguns iniciantes no violoncelo e outros já avançados no instrumento, que mostraram interesse pelo tema. No primeiro encontro, contamos com onze participantes, mas, no segundo, apenas com seis. Assim como ocorreu no Projeto Guri-Polo de Indaiatuba, no primeiro encontro, realizamos quatro jogos de improvisação e no segundo encontro, experimentamos a prática de dois jogos.

Para a interpretação dos dados coletados, foi estabelecido o processo de triangulação dos resultados, obtidos por meio das diferentes fontes de coleta: observação e registro em Diário de Campo, questionários, entrevistas semiestruturadas, anotações dos alunos e gravações em 
vídeo, e minhas impressões pessoais, em associação com a literatura específica da área. A divulgação parcial dos resultados da pesquisa foi apresentada em três momentos, em eventos específicos da área musical, o V SIMPOM (Simpósio Brasileiro de Pós-graduandos em Música) realizado no Rio de Janeiro entre os dias 15 e 18 de maio de 2018, o XVIII Congresso da ANPPOM (Associação Nacional de Pesquisa e Pós-graduação em Música) realizado em Manaus entre os dias 27 e 31 de agosto de 2018 e o VI Congresso da ABRAPEM (Associação Brasileira de Performance em Música) realizado em Natal entre os dias 23 e 26 de outubro de 2018. Os resultados finais do trabalho serão publicados por intermédio dessa dissertação.

O plano de ação dessa pesquisa se baseou na elaboração de material didático direcionado à aplicação em aulas coletivas de violoncelo, contendo os modelos dos jogos trabalhados, suas estratégias de utilização, seus objetivos e propostas, bem como seu referencial teórico. O objetivo desse material é disponibilizar as atividades oferecidas durante as aulas que constituíram a pesquisa de campo, de maneira acessível, aos professores interessados. Também é idealizado o retorno às instituições de ensino envolvidas, a fim de que possam ser disponibilizadas cópias impressas e digitais dessa dissertação, bem como da apostila elaborada a partir das atividades desenvolvidas.

\subsection{INSTRUMENTOS E TÉCNICAS DE COLETA DE DADOS}

Como instrumentos de coleta de dados foram utilizadas algumas abordagens complementares. Foram utilizadas a observação participante, que contou com o apoio de anotações feitas durante as pesquisas de campo e de algumas gravações em vídeo, realizadas durante as aulas, que serviram para a revisão dessas anotações, um questionário com dez questões, que foi aplicado aos alunos, entrevistas semiestruturadas realizadas junto aos professores que participaram dos jogos, e os relatos individuais dos alunos sobre cada um dos jogos realizados. Conforme sugere Uwe Flick, "as anotações do pesquisador são o meio clássico de documentação na pesquisa qualitativa" (FLICK, 2002, p. 181). Flick (2002) esclarece que tais anotações devem ser feitas logo após o contato com o campo, a fim de manter maior fidelidade com os fatos ocorridos.

Conforme já citado, Gil (1989) considera também que os questionários e as entrevistas fazem parte da maneira mais habitual da coleta de dados da pesquisa-ação. As anotações realizadas pelos alunos também se configuram em um importante mecanismo de coleta, conforme as propostas de Bogdan e Biklen (1994), que consideram que "embora não sejam tão utilizados, os materiais que os sujeitos escrevem por si próprios também são usados como 
dados" (BOGDAN, BIKLEN, 1994, p. 176). Para os autores, esses materiais podem ser de natureza variada, como por exemplo, diários, cartas pessoais, ficheiros pessoais, registros de estudantes e processos.

A seguir relato a maneira como foram abordadas, durante o trabalho, essas diferentes técnicas de coleta de dados.

\subsubsection{Observação participante}

A observação ocorreu no decorrer de cada aula ou encontro realizado. Foram considerados, principalmente, os pontos levantados pelo questionário, ou seja, o conforto ou desconforto no momento da execução dos jogos, a possibilidade de, por meio dos jogos, o violoncelo se configurar como um veículo de expressão pessoal, diferentes possibilidades de classificação dos jogos, como música, brincadeira e/ou exercício, a possibilidade de os jogos auxiliarem os alunos na aprendizagem musical, a possibilidade de os jogos auxiliarem a integração entre os alunos, a possibilidade de os jogos auxiliarem a compreensão da criação musical, e a possibilidade de aproximação dos alunos com o repertório de música contemporânea. Além disso, minha percepção estava direcionada às reações individuais e coletivas que cada jogo proporcionava.

A ideia dessa observação é que pudessem ser notados elementos subjetivos, durante a realização de cada jogo, relacionados a aspectos musicais, sociais, comportamentais e emocionais. Tais observações foram transcritas no Diário de Campo para que pudessem ser analisadas, sob diferentes óticas, posteriormente.

\subsubsection{Diário de Campo}

O Diário de Campo se configurou em anotações pelas quais foram registrados dados diversos, como a descrição das atividades realizadas em aula, o tipo de reação apresentada por cada aluno durante a aula, a participação do grupo, o número de alunos presentes em cada turma, bem como análises pessoais, como por exemplo, a recepção dos jogos pelos alunos e o desenvolvimento dos objetivos propostos por cada jogo. Assim como sugerido por Flick (2002), essas anotações eram realizadas logo após as aulas. 


\subsubsection{Questionários}

O questionário aplicado aos alunos era estruturado em dez questões com respostas de múltipla escolha, que se configuravam como sim, mais ou menos e não. Tal questionário foi elaborado procurando abarcar diferentes aspectos dos jogos de improvisação, a fim de verificar algumas impressões dos alunos a respeito desses aspectos. Foi solicitado aos alunos que o questionário fosse respondido de maneira anônima. Foram respondidos vinte e quatro questionários.

Como já citado, os aspectos contemplados nas perguntas do questionário foram relativos à verificação da realização dos jogos ter proporcionado conforto ou desconforto aos alunos, a verificação dos jogos possibilitarem a utilização do violoncelo como um veículo de expressão pessoal, a verificação da classificação dos jogos como música, brincadeira e/ou exercício, a verificação dos jogos como auxiliares na aprendizagem musical, na integração entre os alunos e na compreensão dos processos de criação musical, e a possibilidade de aproximação dos alunos com o repertório de música contemporânea. As perguntas do questionário, assim como foram apresentadas aos alunos, encontram-se no Apêndice D dessa dissertação.

\subsubsection{Entrevistas semiestruturadas}

As entrevistas semiestruturadas foram aplicadas a quatro professores que participaram das atividades. O objetivo das entrevistas foi fazer uma avaliação dos jogos, segundo a visão dos professores participantes, bem como conhecer com mais detalhes o perfil desses professores. A duração das entrevistas foi em torno de quarenta minutos e essas foram gravadas em áudio e posteriormente transcritas em um caderno com paginação intitulado Caderno de Entrevistas aos Professores, para que pudessem ser analisadas posteriormente, tendo trechos transcritos para essa dissertação.

Segundo Flick (2002), uma entrevista semiestruturada consiste em uma entrevista na qual existem perguntas básicas a serem realizadas com os entrevistados, mas essas sofrem modificações ao longo do seu desenrolar (FLICK, 2002, p. 106). Essas modificações ocorrem pela dinâmica que acontece durante o processo, dependendo das colocações que vão sendo feitas pelos entrevistados. Também abrem espaço para alguns relatos pessoais que podem surgir no decorrer das entrevistas. Sobre esses aspectos, Flick considera que "é uma característica dessas entrevistas que questões mais ou menos abertas sejam levadas à situação de entrevistas na forma de um guia de entrevista. Espera-se que essas questões sejam livremente respondidas 
pelo entrevistado" (FLICK, 2002, p. 106). Segundo o autor, "o entrevistador pode e deve decidir, durante a entrevista, quando e em que sequência fazer quais perguntas" (FLICK, 2002, p. 106).

Para a realização das entrevistas com os professores foi elaborado um roteiro prévio. Além de procurar investigar algumas percepções dos professores sobre os jogos realizados, o roteiro tinha o objetivo de tentar contextualizar essas percepções. Com essa proposta. foi perguntado aos professores como cada um trabalhava a iniciação ao violoncelo e como teria se dado sua própria iniciação, a fim de verificar se os modelos de iniciação que cada professor recebeu se repetiam e influenciavam a sua maneira de ensinar. Além dessas questões, foi indagado aos professores se eles próprios, enquanto instrumentistas, costumavam executar repertório da música contemporânea, procurando traçar um paralelo entre as respostas obtidas e sua interação com a música atual. Também foi perguntado aos professores como cada um costumava trabalhar, junto aos alunos, questões referentes à expressividade e à musicalidade, para que se traçasse um panorama geral sobre como esses conteúdos eram abordados junto aos alunos participantes. Além disso, foi perguntado aos professores se passariam a incorporar em sua maneira de ensino a prática de jogos de improvisação, a fim de verificar se a pesquisa proporcionou uma aproximação dos professores a esses conteúdos. O roteiro das entrevistas realizadas com os professores se encontra no Apêndice E dessa dissertação.

As entrevistas com os professores, além de um veículo para se conhecer as impressões sobre os jogos de improvisação realizados, foi também um espaço no qual eles puderam relatar suas posições, inquietações e ideias sobre a educação musical ao violoncelo. À medida em que as entrevistas iam se desenrolando, os professores se sentiam à vontade para expor seus pensamentos e reflexões sobre a prática docente. Esses apontamentos trazidos pelos professores enriqueceram a proposta inicial, pois foi possível que conhecêssemos mais a fundo alguns dos profissionais que trabalham com o ensino e aprendizagem do violoncelo, despertando, inclusive, a curiosidade em se pesquisar mais sobre esse tema.

\subsubsection{Anotações dos alunos}

Além da aplicação do questionário, as impressões dos alunos sobre os jogos realizados foram recolhidas por meio de relatos feitos por eles ao término de cada encontro. Foram distribuídos aos estudantes, folhas de papel sulfite, lápis e borracha e solicitado que cada um, individualmente, escrevesse, desenhasse ou utilizasse qualquer forma de expressão que desejasse para realizar uma avaliação dos jogos. Era solicitado que, ao escrever, os alunos 
justificassem suas respostas, para que pudessem ser colhidos o maior número de dados possíveis. Não era necessário que os alunos se identificassem em seus relatos. Foram produzidos pelos alunos um total 86 relatos, entre depoimentos e desenhos, que foram utilizados principalmente pelos alunos menores. Além de manifestarem sua opinião sobre os jogos, alguns alunos manifestaram-se sobre o vínculo estabelecido entre professor e aluno e fizeram desenhos sobre o violoncelo. Essas anotações foram organizadas em um caderno com paginação, intitulado Caderno de Anotações dos Alunos, e foram utilizadas na elaboração dos resultados da pesquisa.

\subsubsection{Gravação em vídeo}

A gravação em vídeo de parte das experiências ocorreu nos encontros realizados no Projeto Guri-Polo de Indaiatuba. Tais gravações consistem em uma série de pequenos vídeos nos quais parte das atividades foi registrada e foram realizadas com o auxílio de uma profissional do próprio projeto, que esteve presente durante a realização dos jogos. As gravações auxiliaram na análise dos dados, já que parte das aulas pode ser revivida posteriormente e contribuíram para que algumas das anotações do Diário de Campo fossem mais precisas.

\subsection{INSTRUMENTOS E TÉCNICAS DE ORGANIZAÇÃO E ANÁLISE DOS DADOS}

As técnicas de organização dos dados utilizadas foram a organização do Diário de Campo, com o auxílio da revisão possibilitada pela exibição dos vídeos, a tabulação dos dados dos questionários e posterior transformação dos dados em gráficos, a transcrição das entrevistas gravadas em áudio, a elaboração do Caderno de Entrevistas aos Professores e a organização das anotações dos estudantes em um Caderno de Anotações dos Alunos. Posteriormente, esses dados foram comparados e analisados em conjunto com minhas observações pessoais e com referenciais da literatura da área.

\subsubsection{Organização do Diário de Campo}

O Diário de Campo foi transformado em um caderno com paginação, sendo denominado "Diário de Campo de Marta" ou "DCM". Esse caderno foi usado como referência para a análise das impressões dos alunos. 


\subsubsection{Tabulação dos dados dos questionários}

Os questionários aplicados aos alunos foram organizados em uma planilha, a fim de que pudessem ser observados de uma maneira geral e que as respostas fornecidas pelos alunos pudessem ser catalogadas numericamente. Posteriormente, esses dados foram transformados em gráficos, que serviram como referência para as considerações dos alunos.

\subsubsection{Transcrição das entrevistas}

As entrevistas realizadas com os professores foram transcritas e organizadas em um caderno com paginação, que foi denominado "Caderno de Entrevistas aos Professores" ou "CEP”. Tais dados serviram como referência para as considerações dos professores sobre as aulas.

\subsubsection{Categorização das anotações feitas pelos alunos}

As anotações realizadas pelos alunos foram transcritas em um caderno com paginação que foi denominado "Caderno de Anotações dos Alunos" ou "CAA". Tais anotações serviram como referência para as considerações dos estudantes sobre as aulas. Os desenhos elaborados pelos alunos foram escaneados e acrescentados ao Caderno de Anotações.

\subsection{PRINCÍPIOS ÉTICOS DE PESQUISA}

A fim de preservar a identidade e respeitar as pessoas envolvidas na pesquisa, foram seguidas as orientações recebidas por meio do Programa de Pós-Graduação em Música da Escola de Comunicações e Artes da Universidade de São Paulo (PPGMusECA/USP). Inicialmente, foi explicado a todos os participantes os objetivos da pesquisa e seu funcionamento. Posteriormente, foram aplicados termos de autorização para a participação na pesquisa, sendo que os participantes menores de idade foram autorizados por seus pais. Os professores entrevistados preencheram um termo de consentimento, no qual ficou explicitado que seu nome seria mantido em sigilo. As cópias dos termos de consentimento e das autorizações solicitadas aos alunos das instituições se encontram nos apêndices dessa 
dissertação, ressaltando que nas referidas autorizações encontra-se o nome provisório da pesquisa, que era intitulada como "O violoncelo e os jogos de improvisação". 


\section{CARACTERIZAÇÃO DAS INSTITUIÇÕES, DOS PARTICIPANTES E DAS ATIVIDADES DE INTERVENÇÃO}

Neste quarto capítulo, faço, inicialmente, uma caracterização das três instituições educacionais que participaram desse estudo, com base em informações sobre seus projetos, em minhas observações e no relato dos participantes da pesquisa. Tais informações foram fornecidas pelos professores e diretores, bem como sistematizadas dos sites oficiais de divulgação. Em seguida, apresento o perfil da proposta de intervenção oferecida, trazendo o referencial teórico e os aspectos estruturantes das atividades práticas.

\subsection{O PERFIL DAS INSTITUIÇÕES}

Conforme mencionado, após a definição das instituições de ensino que configuraram o campo empírico desse trabalho, foi realizado um contato inicial por e-mail com os representantes dessas instituições, além de reuniões presenciais com os professores, coordenadores e/ou diretores, em que foram estabelecidos princípios e diretrizes para a sua realização. Sendo assim, foi possível iniciar a pesquisa de campo que ocorreu de diferentes maneiras em cada uma delas. A seguir, apresento mais detalhadamente o perfil das instituições que compuseram o campo de investigação.

\subsubsection{Instituto Baccarelli}

O Instituto Baccarelli caracteriza-se como uma organização sem fins lucrativos (ONG) e atende, conforme seu site oficial, cerca de 1000 alunos por ano. Está situado no bairro de Heliópolis, pertencente a periferia da cidade de São Paulo, localizado próximo à cidade de São Caetano. A instituição possui uma ampla estrutura física, contando com salas de aulas climatizadas, salas de estudo individuais e salas de ensaio adequadas para os grupos orquestrais. Também possui grande número de instrumentos musicais e um sistema de empréstimo desses instrumentos aos alunos, sob determinadas condições. Além da sua estrutura física, disponiza um ônibus particular que auxilia os alunos na sua locomoção para as aulas. A instituição conta também com o apoio de diversos patrocinadores do meio empresarial para a manutenção de suas atividades.

Segundo as informações disponibilizadas, a sua premissa pedagógica é "proporcionar uma formação musical e artística de excelência, contribuindo, desta forma, para o 
desenvolvimento pessoal e criando oportunidades de profissionalização na música erudita" (BACCARELLI, 2016). Além da profissionalização, a instituição prima por objetivos e qualidades como a autodisciplina, respeito e criatividade, convivência e senso colaborativo em grupo, considerados essenciais, pelo Instituto Baccarelli, para a formação e o desenvolvimento do cidadão.

O Instituto Baccarelli iniciou suas atividades no final dos anos 1990, quando imagens de um incêndio no bairro de Heliópolis provocaram no maestro Sílvio Baccarelli o desejo de proporcionar um "alento em forma de música" aos jovens dessa comunidade. Inicialmente, os jovens recebiam aulas de instrumentos e formavam uma orquestra de cordas num espaço na casa do maestro na Vila Mariana. Em 2005, com o crescimento do projeto, a instituição mudouse para a Estrada das Lágrimas, no bairro de Heliópolis, onde quatro anos depois, foi inaugurada a sede da instituição, que ocupa hoje uma área de cinco mil metros quadrados.

O projeto de ensino do Instituto Baccarelli inicia com aulas de canto coral. Também são oferecidas aulas de musicalização para as crianças mais novas e as aulas de instrumento musical iniciam-se coletivamente. Segundo a instituição, o propósito das aulas em grupo é que o aluno se dê conta desde cedo que "fazer música é aprender a dialogar" (BACCARELLI, 2016). Seguindo essa premissa, o Instituto Baccarelli mantém em seu processo de ensino diversas atividades coletivas, grupos de música de câmara e atividades orquestrais, em grupos infantis e semiprofissionais, como a Orquestra Sinfônica Heliópolis, que se configura no ponto de chegada de um trabalho de base realizado pelo instituto. Segundo a instituição, "a arte e a prática musical são compreendidas, antes de mais nada, como um poderoso instrumento de transformação individual” (BACCARELLI, 2016).

\subsubsection{Projeto Guri}

O Projeto Guri define-se como um programa sociocultural, mantido pela Secretaria da Cultura do Estado de São Paulo, em parceria com as prefeituras das cidades envolvidas, e atende por ano cerca de 49 mil alunos, divididos em 400 polos de ensino distribuídos pelo estado. O Projeto Guri oferece cursos de iniciação musical, lutheria, canto coral, tecnologia em música, instrumentos de cordas dedilhadas e friccionadas, sopros, teclados e percussão, para crianças e adolescentes entre seis e dezoito anos. Os polos do Projeto Guri atingem o estado de São Paulo de maneira ampla e abrangente, e estão localizados na grande São Paulo, no interior e no litoral. Esses polos são administrados pela Amigos do Guri, que é uma organização social de cultura, e que conta com o apoio de prefeituras, outras organizações sociais, empresas e pessoas físicas. 
O Projeto Guri conta com diversos apoiadores e patrocinadores do meio empresarial, e também recebe doações de pessoas físicas através de diferentes maneiras, como por exemplo, através de doações via desconto no imposto de renda.

O Projeto Guri iniciou suas atividades em 1995, e desde lá, segundo a instituição, já atendeu cerca de 650 mil jovens. Segundo o site oficial, sua missão é "promover, com excelência, a educação musical e a prática coletiva da música, tendo em vista o desenvolvimento humano de gerações em formação" (AMIGOS DO GURI, 2014). A instituição tem como valores fundamentais a "excelência, a criatividade, a responsabilidade, a diversidade, a cooperação e a equidade" (AMIGOS DO GURI, 2014).

Os programas e projetos da Amigos do Guri estão baseados em políticas e práticas com foco na inclusão e na manutenção de alunos em situação de vulnerabilidade econômica e social.

\footnotetext{
Para isso, seus programas e projetos propõem às crianças e jovens a potencialização de suas dimensões estética, afetiva, cognitiva, motora e social, a garantia de vivências enriquecedoras de sociabilidade, o fortalecimento no reconhecimento de seus recursos - que possam ser acionados em projetos de futuro -, o acesso e a valorização das diferentes expressões culturais e o estímulo a criações e apresentações de grupos musicais. (AMIGOS DO GURI, 2014)
}

A estrutura física do Projeto Guri é garantida pelas prefeituras de cada cidade onde os polos estão estabelecidos. Além do espaço físico, as prefeituras são responsáveis pelo mobiliário e demais equipamentos utilizados durante as aulas. No caso do Polo de Indaiatuba, as atividades ocorrem em um centro cultural que pertence a Prefeitura de Indaiatuba, que se localiza no bairro central da cidade.

\subsubsection{Instituto Fukuda}

O Instituto Fukuda é uma escola de música privada e mantém sua sede no bairro Aclimação, na capital do estado de São Paulo. Iniciou suas atividades no ano de 2008, tendo sua inspiração na Escola Fukuda, fundada há mais de quarenta anos por Yoshitame Fukuda. Segundo a instituição, originou-se "do desejo de formalização e amplificação dos horizontes de instrumentos de cordas" (FUKUDA, [s.d.]). O objetivo do Instituto Fukuda é "promover um ensino de qualidade e difundir a cultura musical através de cursos, palestras, workshops e concertos"(FUKUDA, [s.d.]). 
A instituição oferece cursos de violino, viola, violoncelo, piano, clarinete, flauta doce e flauta transversal, além de musicalização infantil, teoria musical, música de câmara e canto coral. Também possui diversos grupos formativos, como o Fukuda Cello Ensemble, a Orquestra Kodomô, a OIF- Orquestra Instituto Fukuda e o Ensemble Fukuda. Esses grupos são compostos por alunos da própria instituição e por convidados.

O grupo de violoncelos da escola, o Fukuda Cello Ensemble, foi criado em 2006 e é integrado, desde então, por violoncelistas estudantes do Instituto Fukuda e por violoncelistas convidados. O objetivo do grupo é ampliar e desenvolver a percepção da prática de conjunto. Segundo o site da instituição, o repertório que o grupo executa transita entre o erudito e o popular, com obras originais e adaptações para essa formação (FUKUDA,[s.d.]).

\subsection{O PERFIL DOS PARTICIPANTES}

A pesquisa aplicada nas três instituições de ensino contou com a participação de vinte e quatro estudantes e quatro professores, que acompanharam as aulas desenvolvidas e também participaram das entrevistas semiestruturadas. A seguir relato o perfil dos estudantes e dos professores, conforme pude observar através da minha inserção nos campos empíricos, da realização das entrevistas e de informações disponíveis nos sites das instituições.

\subsubsection{Os professores}

Os professores que participaram da pesquisa, pertencentes ao quadro das instituições, apresentam perfis diversos, porém com algumas características em comum. Possuem vínculo funcional com as instituições onde trabalham, embora esse vínculo ocorra de diferentes maneiras, dependendo do caráter e perfil de cada uma delas.

Alguns desses professores possuem formação conservatorial ou em escolas especializadas de música e outros realizaram também formação superior universitária, no curso de Bacharelado em Violoncelo. Dois professores também possuem capacitação e formação pelo Método Suzuki.

Todos os professores participam, ou participaram, de grupos instrumentais profissionais, como orquestras e grupos de câmara. Os quatro professores tiveram uma iniciação musical nos moldes tradicionais. Dois deles iniciaram com a prática de ensino coletivo, em projetos sociais, mas posteriormente passaram a receber aulas individuais. Os 
outros dois iniciaram o seu processo de aprendizagem por meio do modelo de aulas individuais, realizadas em conservatórios de música.

\subsubsection{Os alunos}

Os alunos que participaram da pesquisa eram crianças, adolescentes e jovens, entre oito e vinte anos de idade, além de dois adultos, e eram provenientes de diferentes regiões do estado de São Paulo. Os alunos do Instituto Baccarelli estavam na faixa etária dos oito aos quatorze anos de idade e pertencem a famílias da região do bairro de Heliópolis, cidade de São Paulo, que abriga famílias de baixa renda e poder aquisitivo.

Os alunos do Projeto Guri-Polo de Indaiatuba eram provenientes das cidades de Indaiatuba e Monte Mor, interior do estado de São Paulo. Tais alunos possuíam entre oito a vinte anos e eram integrantes do Projeto Guri e de uma escola especializada em música do município de Indaiatuba, o Centro Suzuki de Indaiatuba.

Os alunos do Instituto Fukuda eram habitantes da cidade de São Paulo e possuíam entre oito e vinte anos. Também estavam presentes dois adultos que frequentavam as aulas na instituição. Os alunos eram estudantes da própria instituição, bem como convidados de outros espaços educacionais da cidade.

\subsection{O PERFIL DA PROPOSTA E SEUS PRESSUPOSTOS TEÓRICOS}

Conforme relatado anteriormente, a proposta de trabalho oferecida às instituições se estruturava em modelos de jogos de improvisação coletiva, direcionados a iniciantes ao violoncelo. Para a elaboração da proposta foi necessária a realização de uma revisão bibliográfica sobre o tema da improvisação e sua utilização como recurso pedagógico. Foi necessária, também, a definição e o direcionamento da aplicação do trabalho para o processo coletivo de ensino. Sendo assim, foram observados alguns princípios do ensino coletivo de instrumentos musicais, bem como abordadas algumas ideias, conceitos e funções do jogo, relacionadas à arte e à música, e também, mais especificamente, à improvisação. O estudo dessas ideias direcionou a organização e a escolha dos jogos como fonte de trabalho.

Foram pesquisados e catalogados modelos de jogos de improvisação que já haviam sido aplicados em outros grupos de alunos. Foi feita uma seleção desses jogos, num total de dez, para serem aplicados em aulas e encontros com os alunos de violoncelo iniciantes. Em seguida, foi feita uma busca de instituições de ensino, localizadas no estado de São Paulo, que 
trabalhassem com o ensino coletivo do violoncelo, e que poderiam aderir às ideias da pesquisa. Como relatado em capítulo anterior, foram escolhidos o Instituto Baccarelli, o Projeto Guri e o Instituto Fukuda, por se configurarem em instituições representativas do perfil estabelecido para a pesquisa. Para a realização da pesquisa de campo no Projeto Guri e no Instituto Fukuda, foi necessária uma adaptação da proposta inicial de dez encontros, por ser essa proposta incompatível com a estrutura organizacional das instituições. Sendo assim, foi proposto para essas instituições o modelo de dois encontros, em forma de oficinas, em que foram condensados e aplicados mais de um jogo por encontro, num total de seis jogos.

A ideia da proposta foi oferecer aos participantes a prática de jogos de improvisação com a intenção de despertar a criatividade e a expressividade, através da construção de "narrativas musicais". Os objetivos gerais dos jogos eram desenvolver liberdade de relacionamento com o instrumento em vários planos, desenvolver a qualidade da escuta, trabalhar a autoestima e o autoconhecimento, trabalhar a atenção, a concentração, a criatividade, a autonomia, a liderança e o espírito de grupo, aproximando também os estudantes das poéticas da música contemporânea. Tais objetivos se basearam nas ideias de educadores musicais estudados durante a revisão bibliográfica, sobretudo François Delalande (2001), Violeta Gainza (2009) e Hans-Joachin Koellreutter (1997). O total dos dez jogos selecionados foram reduzidos para sete, na aplicação prática, por questões de viabilidade em relação ao tempo disponível para a realização do trabalho. Esses modelos foram adaptados de modelos elaborados pelos educadores Maria Teresa Alencar de Brito, Claudia Freixedas, Violeta Gainza e Wanderson Cruz, e, como citado anteriormente, alguns foram criados especialmente para o trabalho.

A principal dificuldade encontrada durante a aplicação do trabalho foi viabilizar a contextualização dos jogos dentro de um modelo tradicional de ensino. Os estudantes que participaram das atividades não estavam acostumados à práticas de exploração do instrumento e de criação musical, sendo uma novidade para eles a implementação de tal proposta, dentro do contexto educacional em que estavam inseridos. A adesão dos professores ao trabalho facilitou esse contato, pois os alunos se sentiram seguros para participarem de todas as atividades.

Outra dificuldade encontrada durante a realização do trabalho foi a restrição de tempo disponível. Ao término dos jogos, muitas vezes, seria necessária e importante a sua repetição em um momento posterior, para que pudessem ser incorporados novos elementos à proposta inicial e, assim, acrescentar diferentes experiências aos estudantes. Em função do curto espaço de tempo disponível para a realização desse trabalho, não foi possível fazer a repetição dos jogos, com exceção do Instituto Baccarelli, onde algumas vezes, isso foi viável. 
Também foi uma dificuldade importante a formação do vínculo professor/aluno em tão curto espaço de tempo. Esse vínculo é necessário para o bom desenvolvimento de atividades relacionadas ao ensino e aprendizagem e em tais circunstâncias foi necessária uma adaptação de ambas as partes para que o trabalho se desenvolvesse. No Instituto Baccarelli, esse vínculo foi mais forte por ter sido destinado ao trabalho a duração de dez encontros. Em alguns momentos, em suas anotações pessoais, os alunos do Instituto Baccarelli descreviam suas impressões sobre a minha atuação enquanto professora, às vezes, demonstrando sinais de afeto e identificação. Também demonstraram tristeza ao término das atividades, relatando que gostariam que as atividades continuassem por mais tempo.

\subsubsection{A seleção dos jogos para as aulas}

Como mencionado anteriormente, a seleção dos jogos a serem aplicados nas instituições partiu da ideia de aplicação de jogos de improvisação já testados em outros grupos de estudantes. Alguns desses jogos foram elaborados para serem utilizados em aulas de musicalização, com a utilização de instrumentos de percussão ou por meio do uso da voz, e outros jogos foram elaborados para a aplicação com instrumentos musicais. A escolha desses jogos visou sua adequação à técnica e execução ao violoncelo, buscando a aproximação e o contato dos alunos com as características específicas do instrumento. Também foi levada em conta a possibilidade de todos os jogos serem executados por alunos iniciantes ao violoncelo, ou seja, que os jogos não apresentassem dificuldades e desafios que não pudessem ser superados pelo aluno iniciante. Alguns jogos foram criados para a pesquisa tendo em vista esses mesmos aspectos. A seguir, apresento cada um dos jogos selecionados, seus objetivos e metodologia de aplicação.

Tabela 1-Descrição do Jogo 1

\begin{tabular}{|c|}
\hline Jogo 1 \\
\hline Pergunta e Resposta com cordas soltas em pizzicato \\
\hline Autor(a) \\
\hline Marta Brietzke \\
\hline Objetivos \\
\hline Objetivos gerais: Desenvolver liberdade de relacionamento com o instrumento em vários planos, \\
\hline
\end{tabular}


físico, mental e emocional; proporcionar conhecimento dos recursos sonoros que o violoncelo possui; trabalhar as diferenças de intensidade, ritmos, caracteres e métricas; trabalhar a atenção, a concentração, a criatividade, a liderança e o espírito de equipe; desenvolver a atenção na escuta; trabalhar a autoestima e o autoconhecimento; trabalhar a autonomia dos estudantes, a expressão da individualidade e seu papel na coletividade; aproximar os estudantes a poéticas da música contemporânea.

Objetivos específicos: Trabalhar o conceito de frase musical, de pergunta e de resposta; estabelecer as semelhanças e diferenças entre as sonoridades das quatro cordas do violoncelo.

\section{Metodologia}

Os alunos são estimulados a executar uma improvisação com as cordas soltas do violoncelo em pizzicato. Essa improvisação acontece em duplas, em forma de perguntas e respostas, sendo que o professor faz a pergunta e o aluno faz uma resposta a esta pergunta, utilizando diferentes ritmos, caracteres e níveis de dinâmica. Os alunos são encorajados a realizar a improvisação, ora usando uma corda apenas, ora duas ou mais cordas. Posteriormente, os alunos se dispõem em duplas e escolhem quem faz a pergunta, quem faz a resposta. Cada dupla se dispõe em um local da sala e faz o exercício. Logo após, as duplas apresentam algumas perguntas e respostas para os demais colegas.

Fonte: Elaborado pela autora.

Tabela 2-Descrição do Jogo 2

\begin{tabular}{|c|}
\hline Jogo 2 \\
\hline Sinal Verde X Sinal Vermelho \\
\hline Autor(a) \\
\hline Maria Teresa Alencar de Brito/Murray Schafer \\
\hline Objetivos \\
\hline $\begin{array}{l}\text { Objetivos gerais: Desenvolver liberdade de relacionamento com o instrumento em vários planos, } \\
\text { físico, mental e emocional; proporcionar conhecimento dos recursos sonoros que o violoncelo possui; } \\
\text { trabalhar as diferenças de intensidade, ritmos, caracteres e métricas; trabalhar a atenção, a } \\
\text { concentração, a criatividade, a liderança e o espírito de equipe; desenvolver a atenção na escuta; } \\
\text { trabalhar a autoestima e o autoconhecimento; trabalhar a autonomia dos estudantes, a expressão da } \\
\text { individualidade e seu papel na coletividade; aproximar os estudantes a poéticas da música } \\
\text { contemporânea. } \\
\text { Objetivos específicos: Trabalhar as diferenças entre som e silêncio, bem como sua importância e papel } \\
\text { dentro da construção musical; aprofundar a importância da coletividade dentro do processo musical; } \\
\text { estabelecer a ideia de diálogo musical. }\end{array}$ \\
\hline Metodologia \\
\hline $\begin{array}{l}\text { Antes da realização do jogo, os alunos são convidados a conhecerem, por meio da exploração, alguns } \\
\text { dos recursos do violoncelo, bem como diferentes maneiras de tocá-lo, tendo como ponto de partida a } \\
\text { demonstração prática do professor e posterior experimentação. Logo após, são encorajados a, } \\
\text { sozinhos, buscarem maneiras de tirar outros sons do violoncelo e as compartilharem com os outros } \\
\text { alunos da turma, que também os experimentarão. Após esse momento, passa-se à execução do jogo. } \\
\text { O jogo consiste em se escolher um aluno para ser o regente ou maestro. Esse aluno se posiciona com } \\
\text { dois pequenos cartazes, semelhantes a "placas de trânsito", um cartaz verde e um cartaz vermelho. } \\
\text { Assim ele indica aos demais alunos se devem executar sons ou silêncios. Podem ser escolhidos um }\end{array}$ \\
\hline
\end{tabular}


som por aluno em uma versão, ou sons livres em outra versão, trabalhando-se também diferentes graus de intensidade ou dinâmica. Os alunos podem se revezar na função de regentes. Também é possível a divisão do grupo em dois grupos menores, e a distribuição de um conjunto de cartazes para cada maestro. Os maestros, além de indicarem as informações ao seu grupo, devem interagir entre si, criando diálogo e comunicação entre os dois grupos.

Fonte: Elaborado pela autora, com base nas ideias de Maria Teresa Alencar de Brito e Murray Schafer.

Tabela 3-Descrição do Jogo 3

\begin{tabular}{|c|}
\hline Jogo 3 \\
\hline A noite no castelo \\
\hline Autor(a) \\
\hline Claudia Freixedas \\
\hline Objetivos \\
\hline $\begin{array}{l}\text { Objetivos gerais: Desenvolver liberdade de relacionamento com o instrumento em vários planos, } \\
\text { físico, mental e emocional; proporcionar conhecimento dos recursos sonoros que o violoncelo possui; } \\
\text { trabalhar as diferenças de intensidade, ritmos, caracteres e métricas; trabalhar a atenção, a } \\
\text { concentração, a criatividade, a liderança e o espírito de equipe; desenvolver a atenção na escuta; } \\
\text { trabalhar a autoestima e o autoconhecimento; trabalhar a autonomia dos estudantes, a expressão da } \\
\text { individualidade e seu papel na coletividade; aproximar os estudantes a poéticas da música } \\
\text { contemporânea. } \\
\text { Objetivos específicos: Estabelecer uma relação entre o imaginado e o sonoro; reforçar a confiança } \\
\text { entre os pares; desenvolver o poder de escolha dentro da criação musical. }\end{array}$ \\
\hline Metodologia \\
\hline $\begin{array}{l}\text { Nesse jogo se conta uma história de um visitante que chega até um castelo mal-assombrado em meio } \\
\text { a uma noite de tempestade. Se cataloga, junto aos alunos, alguns objetos que poderiam estar dentro } \\
\text { do castelo, bem como alguns sons externos que são decorrentes da tempestade. Os alunos são } \\
\text { dispostos aleatoriamente em diferentes pontos da sala e cada aluno representa um objeto do castelo. } \\
\text { Um dos alunos, que é escolhido para ser o viajante, é vendado. O objetivo do jogo é que o viajante } \\
\text { caminhe pelo castelo sem bater em nenhum objeto. Quando o viajante se aproxima dos objetos, o } \\
\text { aluno que o representa, executa um som escolhido por ele. À medida que o viajante se afasta, o aluno } \\
\text { deixa de executar seu som e o aluno que representa o objeto mais próximo do viajante executa o seu } \\
\text { som correspondente. O aluno que representa o viajante pode ser estimulado a se posicionar } \\
\text { propositalmente em frente a algum objeto do qual ele deseja ouvir o som e assim "compor" uma } \\
\text { narrativa musical. }\end{array}$ \\
\hline
\end{tabular}

Fonte: Elaborado pela autora, com base nas ideias de Claudia Freixedas.

Tabela 4- Descrição do Jogo 4 


\begin{tabular}{|c|}
\hline Autor(a) \\
\hline Wanderson Cruz \\
\hline Objetivos \\
\hline $\begin{array}{l}\text { Objetivos gerais: Desenvolver liberdade de relacionamento com o instrumento em vários planos, } \\
\text { físico, mental e emocional; proporcionar conhecimento dos recursos sonoros que o violoncelo possui; } \\
\text { trabalhar as diferenças de intensidade, ritmos, caracteres e métricas; trabalhar a atenção, a } \\
\text { concentração, a criatividade, a liderança e o espírito de equipe; desenvolver a atenção na escuta; } \\
\text { trabalhar a autoestima e o autoconhecimento; trabalhar a autonomia dos estudantes, a expressão da } \\
\text { individualidade e seu papel na coletividade; aproximar os estudantes a poéticas da música } \\
\text { contemporânea. } \\
\text { Objetivos específicos: Possibilitar a experiência de criação a partir de células musicais pré- } \\
\text { estabelecidas; proporcionar diferenças entre as polifonias e homofonias; incentivar o poder de escolha } \\
\text { dentro da criação musical. }\end{array}$ \\
\hline Metodologia \\
\hline $\begin{array}{l}\text { Nesse jogo os alunos são estimulados a criarem com seus instrumentos uma assinatura musical, } \\
\text { podendo usar diferentes combinações dos sons inventariados previamente. Após cada um criar sua } \\
\text { assinatura, os alunos as apresentam aos seus colegas. Em seguida, um aluno é escolhido para atuar } \\
\text { como regente, "compondo" uma narrativa formada pelas assinaturas que deseja ouvir. O aluno escolhe } \\
\text { a duração e a intensidade das assinaturas, bem como as possíveis combinações entre elas. }\end{array}$ \\
\hline
\end{tabular}

Fonte: Elaborado pela autora, com base nas ideias de Wanderson Cruz.

Tabela 5- Descrição do Jogo 5

\begin{tabular}{|c|}
\hline Jogo 5 \\
\hline Igual X Parecido X Diferente \\
\hline Autor(a) \\
\hline Violeta Gainza \\
\hline Objetivos \\
\hline $\begin{array}{l}\text { Objetivos gerais: Desenvolver liberdade de relacionamento com o instrumento em vários planos, } \\
\text { físico, mental e emocional; proporcionar conhecimento dos recursos sonoros que o violoncelo possui; } \\
\text { trabalhar as diferenças de intensidade, ritmos, caracteres e métricas; trabalhar a atenção, a } \\
\text { concentração, a criatividade, a liderança e o espírito de equipe; desenvolver a atenção na escuta; } \\
\text { trabalhar a autoestima e o autoconhecimento; trabalhar a autonomia dos estudantes, a expressão da } \\
\text { individualidade e seu papel na coletividade; aproximar os estudantes a poéticas da música } \\
\text { contemporânea. } \\
\text { Objetivos específicos: Trabalhar as ideias de similaridade e diferença em música; proporcionar a } \\
\text { criação a partir de um elemento dado previamente; trabalhar a ideia de frases ou narrativas musicais. }\end{array}$ \\
\hline Metodologia \\
\hline $\begin{array}{l}\text { São apresentados aos alunos três pequenos cartazes. Em um cartaz está representado o sinal } \\
\text { matemático utilizado para "igual", no segundo cartaz está representado o sinal matemático utilizado } \\
\text { para "diferente" e no terceiro cartaz está um sinal criado pelo grupo ou pelo professor para representar }\end{array}$ \\
\hline
\end{tabular}


"parecido". Os alunos são dispostos em fila. O primeiro aluno cria livremente uma frase musical, utilizando os recursos e os sons que desejar. Em seguida, é oferecido um dos cartazes ao segundo aluno. Conforme a indicação do cartaz o segundo aluno mantém ou varia a primeira frase. Logo após é oferecido um cartaz ao terceiro aluno, que mantém ou varia a frase executada pelo segundo aluno. Esse procedimento é repetido até que todos os alunos tenham participado do jogo. Num segundo momento se escolhe um dos alunos para mostrar os cartazes aos colegas. Como variação, esse aluno pode escolher também quem será o próximo aluno a tocar, variando a ordem de execução.

Fonte: Elaborado pela autora, com base nas ideias de Violeta Gainza.

Tabela 6-Descrição do Jogo 6

\begin{tabular}{|c|}
\hline Jogo 6 \\
\hline Composição com gravuras e escrita com notação própria \\
\hline Autor(a) \\
\hline Diversos autores/Marta Brietzke \\
\hline Objetivos \\
\hline $\begin{array}{l}\text { Objetivos gerais: Desenvolver liberdade de relacionamento com o instrumento em vários planos, } \\
\text { físico, mental e emocional; proporcionar conhecimento dos recursos sonoros que o violoncelo possui; } \\
\text { trabalhar as diferenças de intensidade, ritmos, caracteres e métricas; trabalhar a atenção, a } \\
\text { concentração, a criatividade, a liderança e o espírito de equipe; desenvolver a atenção na escuta; } \\
\text { trabalhar a autoestima e o autoconhecimento; trabalhar a autonomia dos estudantes, a expressão da } \\
\text { individualidade e seu papel na coletividade; trabalhar a autonomia dos estudantes, a expressão da } \\
\text { individualidade e seu papel na coletividade; aproximar os estudantes a poéticas da música } \\
\text { contemporânea. } \\
\text { Objetivos específicos: Aproximar os alunos da ideia de composição; desenvolver uma simbologia } \\
\text { própria que represente suas ideias musicais, fazer contato com diferentes maneiras de escrita e } \\
\text { representação musical; atentar para as limitações existentes em qualquer tipo de escrita musical; } \\
\text { aproximar compositores. e intérpretes. }\end{array}$ \\
\hline Metodologia \\
\hline $\begin{array}{l}\text { Nesse jogo são oferecidas aos alunos algumas gravuras ou fotos com imagens diversas. A classe é } \\
\text { dividida em grupos, compostos por uma média de cinco pessoas por grupo. É solicitado aos grupos } \\
\text { que escolham uma ou quantas gravuras desejarem para contar uma história musical. Podemos dar um } \\
\text { exemplo com nosso próprio instrumento. Pedimos que os alunos criem, inicialmente, uma história } \\
\text { que possua início, meio e fim. Em seguida, estimulamos os alunos a representarem essa história apenas } \\
\text { com sons oriundos dos seus violoncelos. Logo após, distribuem-se aos alunos cartolina, lápis } \\
\text { coloridos e outros materiais que se considere importantes, como por exemplo, fitas coloridas, } \\
\text { barbantes, pedrinhas, palitos de dentes, etc. Os alunos são solicitados a "escreverem" sua música na } \\
\text { cartolina, usando para isso os materiais que desejarem em forma de desenhos, palavras, símbolos, ou } \\
\text { o que julguem apropriado para esse fim. Em seguida, os alunos são estimulados a praticar algumas } \\
\text { vezes sua música, utilizando ou não a partitura, e logo após, a apresentar a música criada aos demais } \\
\text { colegas. }\end{array}$ \\
\hline
\end{tabular}

Fonte: Elaborado pela autora. 
Tabela 7- Descrição do Jogo 7

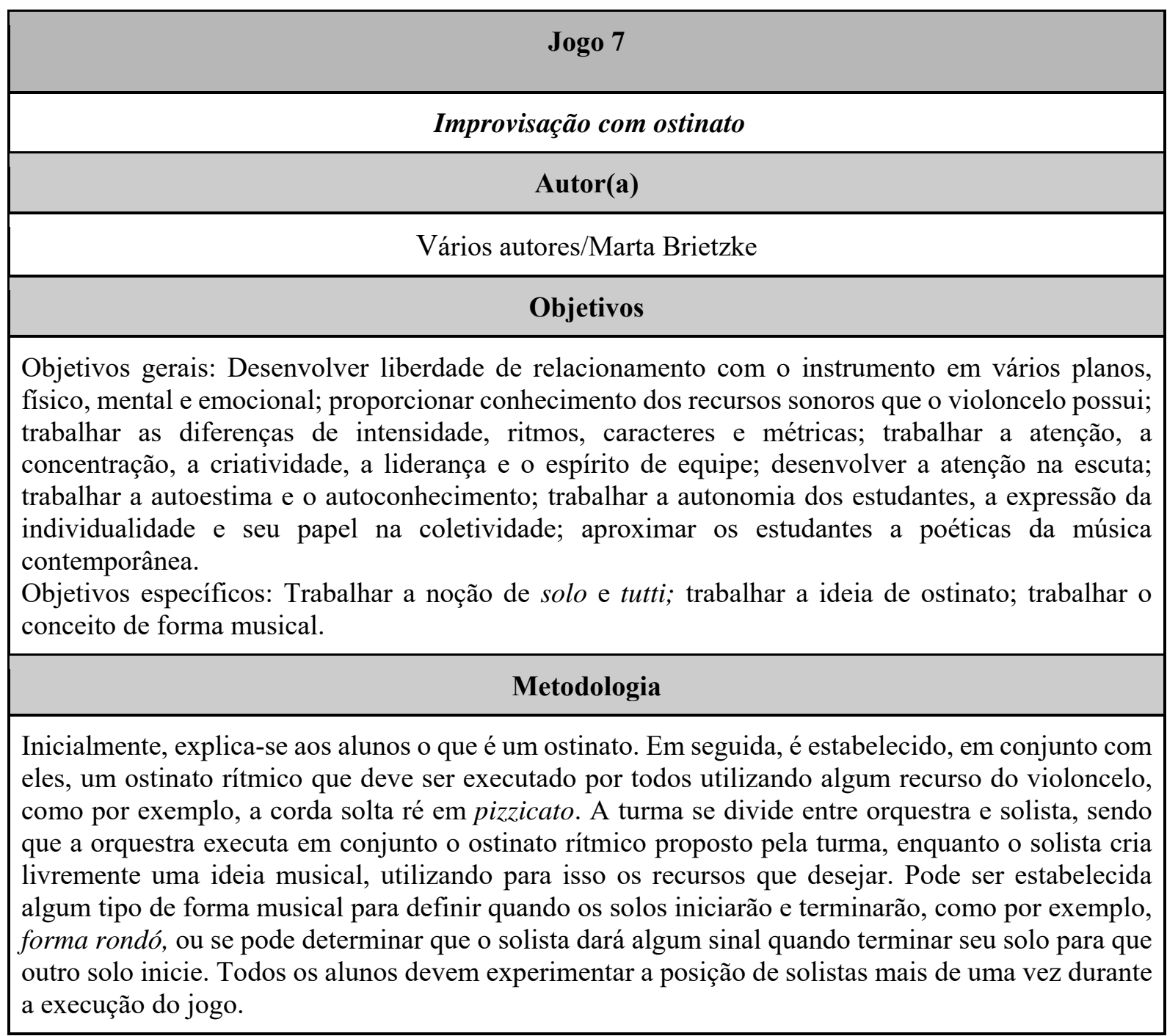

Fonte: Elaborado pela autora.

Tabela 8-Descrição do Jogo 8

\begin{tabular}{|c|}
\hline Jogo 8 \\
\hline A floresta encantada \\
\hline \multicolumn{1}{|c|}{ Autor(a) } \\
\hline Claudia Freixedas \\
\hline \multicolumn{1}{|c|}{ Objetivos } \\
\hline $\begin{array}{l}\text { Objetivos gerais: Desenvolver liberdade de relacionamento com o instrumento em vários planos, } \\
\text { fisico, mental e emocional; proporcionar conhecimento dos recursos sonoros que o violoncelo possui; } \\
\text { trabalhar as diferenças de intensidade, ritmos, caracteres e métricas; trabalhar a atenção, a } \\
\text { concentração, a criatividade, a liderança e o espírito de equipe; desenvolver a atenção na escuta; } \\
\text { trabalhar a autoestima e o autoconhecimento; trabalhar a autonomia dos estudantes, a expressão da } \\
\text { individualidade e seu papel na coletividade; aproximar os estudantes a poéticas da música }\end{array}$ \\
\hline
\end{tabular}


contemporânea.

Objetivos específicos: Trabalhar o diálogo musical; trabalhar a ideia de polifonia.

\section{Metodologia}

Esse jogo se baseia em uma história sobre uma floresta encantada, na qual cada árvore que compõe essa floresta emite um som próprio. Os alunos se posicionam em diferentes pontos da sala, de maneira semelhante ao jogo $A$ noite no castelo. Dois exploradores chegam à floresta e iniciam um passeio por meio dela. $\mathrm{O}$ jogo funciona de maneira similar ao jogo A noite do castelo, porém, como teremos a participação de dois exploradores ao mesmo tempo, cria-se uma espécie de polifonia entre as duas construções musicais.

Fonte: Elaborado pela autora, com base nas ideias de Claudia Freixedas.

Tabela 9- Descrição do Jogo 9

\begin{tabular}{|c|}
\hline Jogo 9 \\
\hline Passeio no zoológico \\
\hline Autor(a) \\
\hline Violeta Gainza \\
\hline Objetivos \\
\hline $\begin{array}{l}\text { Objetivos gerais: Desenvolver liberdade de relacionamento com o instrumento em vários planos, } \\
\text { físico, mental e emocional; proporcionar conhecimento dos recursos sonoros que o violoncelo possui; } \\
\text { trabalhar as diferenças de intensidade, ritmos, caracteres e métricas; trabalhar a atenção, a } \\
\text { concentração, a criatividade, a liderança e o espírito de equipe; desenvolver a atenção na escuta; } \\
\text { trabalhar a autoestima e o autoconhecimento; trabalhar a autonomia dos estudantes, a expressão da } \\
\text { individualidade e seu papel na coletividade; aproximar os estudantes a poéticas da música } \\
\text { contemporânea. } \\
\text { Objetivos específicos: Trabalhar diferentes opções musicais de uma mesma sonoridade, trabalhar a } \\
\text { ideia de narrativa musical. }\end{array}$ \\
\hline Metodologia \\
\hline $\begin{array}{l}\text { Para esse jogo, cria-se, em conjunto com os alunos, uma narrativa sobre uma pessoa que faz uma } \\
\text { visita ao zoológico. Cada aluno escolhe um animal para ser representado por sons do seu violoncelo. } \\
\text { Os alunos se dispõem em fila e um deles é escolhido para ser o visitante do zoológico. Quando o } \\
\text { visitante se posicionar na frente de um determinado animal, o aluno que o representa emitirá o som } \\
\text { escolhido. O visitante alterna seu posicionamento na frente dos diversos animais, criando assim uma } \\
\text { narrativa musical. A fim de implementar uma variação e aumento de complexidade, os alunos devem } \\
\text { ser estimulados a, quando representarem o papel do visitante, interagir com os animais, por meio de } \\
\text { expressões faciais ou corporais, sendo que cada uma dessas interações promoverá diferentes atuações } \\
\text { musicais dos animais. }\end{array}$ \\
\hline
\end{tabular}

Fonte: Elaborado pela autora, com base nas ideias de Violeta Gainza. 
Tabela 10- Descrição do Jogo 10

\begin{tabular}{|c|}
\hline Jogo 10 \\
\hline Os pássaros e o caçador \\
\hline Autor(a) \\
\hline Claudia Freixedas/Marta Brietzke \\
\hline Objetivos \\
\hline $\begin{array}{l}\text { Objetivos gerais: Desenvolver liberdade de relacionamento com o instrumento em vários planos, } \\
\text { físico, mental e emocional; proporcionar conhecimento dos recursos sonoros que o violoncelo possui; } \\
\text { trabalhar as diferenças de intensidade, ritmos, caracteres e métricas; trabalhar a atenção, a } \\
\text { concentração, a criatividade, a liderança e o espírito de equipe; desenvolver a atenção na escuta; } \\
\text { trabalhar a autoestima e o autoconhecimento; trabalhar a autonomia dos estudantes, a expressão da } \\
\text { individualidade e seu papel na coletividade; aproximar os estudantes a poéticas da música } \\
\text { contemporânea. } \\
\text { Objetivos específicos: Trabalhar a liberdade e as diferentes opções para o início, o desenvolvimento } \\
\text { e o final da "peça" musical, trabalhar questões ligadas à ecologia e à ecologia acústica; trabalhar os } \\
\text { diálogos, as polifonias e a noção de forma musical. }\end{array}$ \\
\hline Metodologia \\
\hline $\begin{array}{l}\text { Nesse jogo os alunos são questionados sobre sons de pássaros conhecidos por eles. Pode-se } \\
\text { inventariar, em conjunto, alguns desses sons, ou solicitar que os alunos façam esse trabalho em suas } \\
\text { casas, ou se pode trazer gravações de diferentes sons de pássaros para que todos escutem em conjunto. } \\
\text { Cada aluno escolhe o som de um pássaro e o reproduz com seu violoncelo. Em conjunto, escolhe-se } \\
\text { um som que representa o som de um caçador que se aproxima da mata. Um aluno é escolhido para } \\
\text { representar o caçador, enquanto os outros representam os pássaros. Os alunos são estimulados a } \\
\text { escolher o momento de iniciar improvisação, e a estabelecer diálogos entre os diferentes pássaros, } \\
\text { utilizando momentos de silêncio e escuta dos demais sons. O aluno que representa o caçador também } \\
\text { escolhe o momento de intervir na improvisação. Quando houver essa intervenção, os pássaros se } \\
\text { calam e reiniciam seu canto quando julgarem que o caçador não representa mais perigo. O caçador } \\
\text { pode intervir quantas vezes desejar, dependendo de suas escolhas musicais e a improvisação termina } \\
\text { quando o grupo julgar que chegou ao fim. }\end{array}$ \\
\hline
\end{tabular}

Fonte: Elaborado pela autora, com base nas ideias de Claudia Freixedas. 


\section{A IMPLEMENTAÇÃO E A AVALIAÇÃO DAS ATIVIDADES}

Nesse quinto capítulo, relato de forma sistemática e analítica a implementação dos jogos de improvisação nas aulas de iniciação coletiva ao violoncelo nas três instituições que fizeram parte dessa pesquisa. Apresento, também, os dados empíricos obtidos por meio dos meus registros em Diário de Campo, dos questionários aplicados junto aos estudantes, das entrevistas realizadas com os professores das instituições e das anotações dos alunos, sempre conectando o material empírico com a literatura consultada. Nas reflexões sobre os dados, busco dialogar com o referencial teórico apresentado no Capítulo 2, trazendo considerações e proposições frentes aos aspectos que constituíram a realização de todas as etapas dessa pesquisa. Por configurar-se como um capítulo de análise, construo, nessa seção, elementos para uma avaliação de todo o processo, trazendo assim subsídios para revisões que possam otimizar propostas semelhantes à implementada nesse trabalho.

\subsection{A IMPLEMENTAÇÃO DOS JOGOS DE IMPROVISAÇÃO}

Como já mencionado, após a seleção dos jogos de improvisação, levei a proposta de aplicá-los nas aulas de violoncelo das três instituições, sendo que a duração dessa etapa variou conforme as possibilidades de cada uma delas. A seguir, apresento um relato sobre a experiência de realizar cada jogo de improvisação, trazendo alguns excertos do meu Diário de Campo. Por fim, trarei falas que expressam a perspectiva dos estudantes e dos professores de violoncelo que participaram das atividades, sobre suas experiências com os jogos abordados, sempre relacionando essas falas com a literatura consultada como referência.

\subsubsection{Pergunta e Resposta com cordas soltas em pizzicato}

Esse jogo foi escolhido para o início do trabalho em todas as instituições, com o objetivo de proporcionar confiança aos alunos em relação às abordagens que seriam desenvolvidas a seguir. Teve como ideia oportunizar aos alunos a possibilidade de que eles se expressassem por meio do violoncelo, utilizando elementos técnicos simples, como as cordas soltas do instrumento e o pizzicato. Inicialmente, expliquei aos alunos sobre a possibilidade da música de atuar como a linguagem verbal, representando frases musicais, podendo organizarse, por exemplo, em forma de perguntas ou respostas. Dei um exemplo com meu instrumento e, em seguida, os alunos foram estimulados a criarem respostas a perguntas que eram propostas 
a eles. Os alunos estavam distribuídos em meia lua e executaram as suas respostas um a um. Inicialmente, eu executava uma pergunta e o primeiro aluno executava sua resposta. Em seguida, eu executava mais uma pergunta e o segundo aluno a resposta, e assim sucessivamente, até que todos os alunos participassem do jogo. Após algumas rodadas do jogo, os alunos foram distribuídos em duplas em diferentes pontos da sala e cada dupla criou uma série de perguntas e respostas, sendo que os alunos se revesaram em cada papel. Após esse momento, os alunos foram estimulados a apresentarem aos seus colegas, em duplas, algumas perguntas e algumas respostas.

Observando as anotações registradas no Diário de Campo, recordo que foi notória a adesão dos alunos à atividade. Algumas dessas anotações dizem respeito à realização da atividade no Instituto Baccarelli.

Durante a execução do jogo foi notável o estado de atenção e de concentração
que este propiciou às alunas. Fizemos duas rodadas do jogo apenas com as
cordas soltas Lá e Ré e duas rodadas utilizando as quatro cordas, o que foi
comemorado pelas estudantes. Após esta etapa, as alunas foram separadas em
duplas, com o objetivo de criarem suas próprias perguntas e respostas para
depois apresentarem às colegas. Cada dupla apresentou um pequeno jogo de
improvisação utilizando as quatro cordas do violoncelo. Em cada dupla,
ambas as alunas assumiram os dois papéis, ora perguntando, ora respondendo.
Foi visível o aumento de complexidade nos temas criados por elas neste
momento em relação aos criados na primeira parte do jogo, o que nos induz a
pensar que esta pequena prática de improvisação fez com que as alunas
exercessem seu papel criativo. A minha impressão é que o jogo Perguntas e
Respostas com cordas soltas instalou um elemento surpresa para as alunas,
que foi a prática da improvisação livre, através de elementos técnicos que elas
dominavam, as cordas soltas e o pizzicato. Desta maneira, as alunas
conseguiram expressar-se musicalmente através do violoncelo, mesmo
dispondo de aparentemente poucas ferramentas. Também observei que este
jogo, por intercalar diferentes momentos de performance e de escuta,
propiciou um aumento da qualidade desta escuta (DCM, 2017, p. 5).

Conforme as anotações do Diário de Campo, considero que essa atividade foi significativa para as estudantes, pois elas demonstraram envolvimento, atenção e concentração. Em contrapartida, considero que esse jogo poderia ter sido realizado outras vezes e que poderiam ter sido incorporadas diferentes nuances de caráter musical na realização das perguntas e das respostas. Esse elemento ficou ausente nas propostas sugeridas, tendo sido destacadas apenas variações de dinâmica e de métrica.

Segundo Brito (2003), a ideia da repetição dos jogos é uma sugestão trazida por Koellreutter, assim como pela própria autora (2003, 2011). Segundo Brito (2003, 2011), os jogos de improvisação devem ser realizados em ocasiões distintas. Em cada realização podem ser abordados diferentes elementos junto aos alunos. Brito $(2003,2011)$ aconselha que a cada 
execução dos jogos sejam acrescentados elementos de maior complexidade musical, a fim de desenvolver diferentes habilidades dos estudantes. Em consonância com essas ideias, faço uma autocrítica ao trabalho, considerando que esse jogo poderia ter oferecido também outros materiais musicais aos alunos, possibilitando o aprofundamento das vivências apresentadas.

\subsubsection{Sinal Verde X Sinal Vermelho}

O jogo Sinal Verde X Sinal Vermelho foi idealizado por Maria Teresa Alencar de Brito e foi adaptado para o violoncelo utilizando algumas ideias pessoais, inspiradas no trabalho de Murray Schafer (2011). Porém, antes da realização desse jogo, os alunos conheceram novas sonoridades e novas maneiras de produção sonora ao violoncelo. Foram apresentadas aos alunos algumas ideias relacionadas às técnicas estendidas, através da imitação, sendo que era executada uma sonoridade e os alunos eram convidados a, em grupo, repeti-la. Em seguida, foi sugerido que os alunos, cada um individualmente, testassem novas maneiras de produção de sons no violoncelo, para que depois, em seguida, apresentassem os sons experimentados aos seus colegas. Os alunos testaram os sons e compartilharam suas descobertas com a turma, que logo após a sua apresentação, os repetia em conjunto.

Para a realização do jogo, foram oferecidos aos alunos dois pequenos cartazes, um cartaz da cor verde e outro da cor vermelha. Esses cartazes foram relacionados com os sinais de trânsito, sendo que o cartaz verde significava "tocar" e o cartaz vermelho significava "não tocar". Os alunos foram orientados a utilizar qualquer som que desejassem para seguir a indicação dos cartazes, podendo optar por um ou mais dos sons inventariados previamente. Eu apresentava os cartazes aos alunos que deveriam seguir a respectiva indicação. Foram acrescentadas também algumas indicações de dinâmica, conforme o posicionamento dos cartazes.

Logo após, foi escolhido um aluno para ser o "maestro" e indicar aos demais alunos quando deveriam tocar e quando deveriam fazer silêncio. Os alunos se revezaram na posição de maestros, em alguns casos, alternando dinâmicas e articulações. As turmas foram também divididas em dois grupos e foi distribuído mais um conjunto de cartazes, escolhendo-se dois maestros para que atuassem simultaneamente. Cada maestro deveria orientar o seu grupo e comunicar-se com o outro maestro, criando um diálogo entre os grupos.

Nas anotações realizadas no Diário de Campo, foi salientada a criação de diferentes formas de expressão e de indicações oferecidas pelos maestros, conforme pode ser observado nas anotações referentes às atividades realizadas no Projeto Guri-Polo de Indaiatuba: 
O resultado foi muito interessante, pois realizamos o jogo três vezes e em cada vez que o realizamos os regentes criaram novos sinais para manifestar seu desejo musical, como por exemplo, balançar os sinais verde e vermelho, trêmulos com os sinais, variações de dinâmicas. Também houve uma intensa comunicação entre os regentes, que construíram diferentes sonoridades em conjunto (DCM, 2017, p. 22).

Porém, algumas anotações relativas à pesquisa de campo no Instituto Baccarelli deixam transparecer que fiquei apreensiva em relação à execução desse jogo nessa instituição. Através das anotações, é possível perceber que considerei que as alunas poderiam estar relacionando a proposta do jogo a um trabalho mecânico de apresentação dos cartazes às colegas e não a um trabalho direcionado a desenvolver a atenção na escuta. Essa observação me faz planejar uma variação do jogo, já citada anteriormente. Essa variação consiste na divisão do grupo em dois, cada grupo com um maestro, possibilitando, assim, a interação entre os maestros. Esta observação foi registrada no Diário de Campo.

Quando foi oferecido que as alunas se tornassem regentes, todas manifestaram interesse em assumir esta posição, sendo que o jogo foi executado mais três vezes, cada vez com uma aluna diferente no papel de regente. As regentes exploraram diferentes dinâmicas e diferentes momentos de som e de silêncio, mas suspeito que esta exploração tenha sido mais mecânica do que pelo resultado sonoro. Esta suspeita me fez planejar que este jogo fosse repetido no próximo encontro e que fosse destacada a atenção na audição, dividindo a turma em dois grupos, para que se criasse uma espécie de diálogo musical entre os grupos (DCM, 2017, p. 7).

Logo após, foram relatadas nas anotações da aula seguinte as sugestões propostas para sanar a dificuldade que foi observada.

Para esta improvisação a turma foi dividida em dois grupos, cada uma com uma regente, com o objetivo de criar diálogos musicais de sons e silêncios entre eles. Fizemos o jogo três vezes, e no meu entender apenas na terceira vez se pode entender o discurso musical, pois neste momento as alunas conseguiram se concentrar mais no jogo e deixar de lado alguns comportamentos eufóricos como falar ou rir. Chamei a atenção delas para este momento, tentando incentivar a escuta ativa. Planejei enfatizar a qualidade de escuta no próximo encontro (DCM, 2017, p. 8).

As considerações relacionadas a esse jogo me fizeram observar com mais atenção a questão da qualidade de escuta, incentivando, nas aulas posteriores, que os alunos se mantivessem mais alertas em relação aos sons que eram produzidos. A importância em se manter a atenção na escuta foi ressaltada na literatura consultada, por exemplo, por Delalande (2001) e Costa (2016). Ambos os autores consideram a qualidade da escuta fundamental para a prática da improvisação. 


\subsubsection{A noite no Castelo}

Esse jogo foi criado por Claudia Maradei Freixedas para flautas doces e adaptado, para a pesquisa, para violoncelos. A ideia do jogo é que se conte uma história sobre um castelo malassombrado e sobre um viajante que chega nesse castelo em meio a uma noite de tempestade. Os alunos se posicionaram em diferentes pontos da sala, representando objetos do castelo e um dos alunos foi vendado, representando o viajante, que deveria executar uma caminhada. Quando o viajante se aproximava dos objetos, o aluno que o representa deveria executar um som escolhido por ele, e quando o viajante se afastava, ele deixava de tocar esse som, e o aluno mais próximo ao viajante passava a tocar o seu som. Dessa maneira, se estabeleceu uma "narrativa" musical.

Esse jogo foi realizado algumas vezes em cada um dos grupos e os alunos foram estimulados a "comporem" a sua narrativa musical, posicionando-se frente aos sons que desejavam ouvir, ou deslocando-se, conforme sua intenção musical. O objetivo do jogo era que o viajante não batesse em nenhum objeto. No Projeto Guri-Polo de Indaiatuba e no Instituto Fukuda, uma das versões do jogo foi gravada em vídeo. Posteriormente, todos os alunos assistiram e comentaram a narrativa criada por eles.

Um dos relatos do Diário de Campo no Instituto Baccarelli aponta para o fato de que a realização desse jogo foi prejudicada nessa instituição por ser a sala de aula de aula de um tamanho restrito, o que impossibilitou que as alunas se movimentassem livremente.

Porém como a sala era muito pequena, a movimentação das alunas ficou um pouco reduzida e não foi possível se escutar um contínuo sonoro amplo (DCM, 2017, p. 9).

Apesar desse fato, conclui que a atividade trouxe benefícios às alunas participantes.

$\mathrm{Na}$ minha percepção este jogo foi muito proveitoso para as alunas. Além de refinar os processos auditivos, trabalhou a independência de cada uma, pois basicamente as alunas atuaram como solistas dentro de um fluxo musical. O jogo também contribuiu para o aumento da capacidade de concentração, pois todas as alunas queriam estar atentas para expressar-se no momento em que sua voz fosse solicitada (DCM, 2017, p. 9).

Através das anotações no Diário de Campo, constato que destaquei a importância de ter realizado, no Projeto Guri-Polo de Indaiatuba e no Instituto Fukuda, a gravação em vídeo para ser assistida posteriormente, em conjunto.

Após a realização do jogo, escutamos esta gravação e os alunos foram instigados a darem seu parecer sobre a peça que foi composta coletivamente no decorrer do jogo. Os alunos disseram que a experiência de ouvir a música foi completamente diferente da experiência de tocar a música, que ao escutar 
puderam sentir mais a continuidade e o fluxo musical, que ao tocar estavam mais preocupados com a execução. Este momento de audição foi importante porque os alunos conseguiram ter ideia de que estavam realmente "compondo" algo em conjunto, que era o resultado coletivo de um trabalho individual (DCM, 2017, p. 18).

Essa experiência corresponde às ideias apontadas por Delalande (2001). Delalande (2001) acredita que, ao gravar as improvisações e ao escutá-las posteriormente, os alunos podem observar a obra de maneira similar ao pintor que dá um passo atrás para analisar sua produção. Para o autor, dessa forma, o aluno estabelece uma relação com a obra enquanto manifestação de suas concepções, ideias e elementos da sua personalidade, podendo assim travar um diálogo consigo mesmo e promover o seu desenvolvimento e crescimento pessoal (DELALANDE, 2001, p. 143). Como autocrítica ao trabalho realizado, considero que os relatos feitos por escrito não proporcioram uma análise compartilhada dos jogos, pois não ocorrerem trocas de ideias e opiniões entre os alunos, já que cada um elaborou seu relato individualmente. Acredito que, em oportunidades futuras, a gravação das improvisações e a análise realizada em conjunto pelos alunos devam ser enfatizadas, a fim de proporcionarem a interação e troca de ideias e de opiniões entre os participantes.

\subsubsection{Assinatura Musical}

Este jogo foi criado pelo violonista e educador Wanderson Cruz e adaptado pela pesquisa, para grupo de violoncelos. Antes da realização do jogo, foi perguntado aos alunos o que significava, para eles, uma assinatura. Em seguida, fazendo uma relação com as respostas apresentadas, foi proposto que cada um criasse a sua assinatura musical, incluindo qualquer combinação de sons que desejassem. Dei um exemplo com meu violoncelo, utilizando sons convencionais e sons provenientes das técnicas estendidas. Os alunos pesquisaram e criaram individualmente as suas assinaturas musicais e foram convidados a apresentarem, um a um, as suas assinaturas aos seus colegas de classe. Após a apresentação das assinaturas, um dos alunos foi escolhido para ser o maestro de uma música que seria composta apenas utilizando as assinaturas criadas por eles. O maestro demonstrava, por meio de gestos, qual assinatura gostaria de ouvir, por quanto tempo e se algumas das assinaturas deveriam ser executadas simultaneamente e com dinâmicas, intenções e variações de velocidades específicas. O jogo foi realizado algumas vezes nas três instituições e os alunos se revezaram no papel de maestro.

Conforme as anotações do Diário de Campo, considero que, da mesma maneira como o que ocorreu no jogo Sinal Verde X Sinal Vermelho, foi necessária, no Instituto Baccarelli, a 
repetição do jogo. Através das anotações realizadas percebo que acreditei que a atenção, que deveria ser direcionada para a escuta, pudesse ter sido dissipada no decorrer da execução do jogo.

A qualidade da execução das assinaturas foi muito positiva, porém a qualidade da escuta não acompanhou igualmente o processo, pelo jogo ter despertado uma certa euforia nas alunas, o que resultou em falas durante a execução. As alunas gostaram muito do jogo, todas queriam ser a regente, por esta razão no próximo encontro decidi propor a repetição deste jogo, com diferentes regentes e tentando chamar a atenção para a qualidade da escuta (DCM, 2017, p. 11).

Já no Projeto Guri-Polo de Indaiatuba, as anotações indicam para o fato de que os alunos demonstraram compreensão sobre as complexidades musicais que surgiram no decorrer do jogo.

No momento proposto para realizarem suas assinaturas em conjunto, com a regência de um dos alunos, eles demonstraram já estarem conscientes das polifonias geradas pelas diferentes assinaturas executadas em conjunto (DCM, 2017, p. 19).

Levando em conta as anotações e as minhas observações, acredito que as diferenças apresentadas se devem às diferentes faixas etárias dos alunos que participaram dos jogos. No Instituto Baccarelli, era maior a presença de alunos com menor faixa etária do que no Projeto Guri-Polo de Indaiatuba. Tal observação aponta para a necessidade de adaptação das propostas, conforme o perfil dos alunos, faixa etária e, também, com o trabalho que vem sendo realizado junto a eles.

Relacionando essas observações e anotações com a literatura consultada, considero que as diferenças de faixa etária apontam também para a possibilidade da estruturação de jogos de improvisação direcionados tanto para crianças quanto para adolescentes e jovens. Violeta Gainza (2009) chama a atenção para o fato de que diferentes faixas etárias reagem de diferentes formas frente às atividades de improvisação (GAINZA, 2009, p. 16). A autora explica, por exemplo, que as crianças aderem melhor às propostas de improvisação do que os adolescentes, que, frequentemente, se mostram tímidos ou retraídos. As manifestações apresentadas pelos alunos durante a pesquisa de campo acrescentam a compreensão de que os jogos de improvisação coletiva também são bem aceitos pelos adolescentes e jovens, e não apenas pelas crianças, podendo constituírem-se como alternativa para atividades de improvisação realizadas individualmente.

A resposta positiva dada pelos adolescentes, nesse e em outros jogos, sinaliza para o fato de que os jogos não foram considerados atividades "infantilizadas" ou desconectadas com 
a sua faixa etária, e sim, atividades nas quais eles puderam desenvolver conteúdos expressivos relacionados às propostas musicais apresentadas. Essa aceitação, demonstrada pelos alunos adolescentes em relação aos jogos, dialoga com o apontamento de Delalande (2001), ao considerar a música, como manifestação lúdica própria de infância, uma forma de "transgressão social” (DELALANDE, 2001, p. 29). Para Delalande (2001), a música possibilita a manutenção do jogo em todo o período escolar, e não apenas nas atividades destinadas às crianças (DELALANDE, 2001, p. 28). Além disso, para o autor, ao mantermos a música em nossas vidas enquanto adolescentes e adultos, estamos mantendo também o comportamento lúdico próprio da primeira infância, que, muitas vezes, não é permitido em outras instâncias sociais. (DELALANDE, 2001, p. 28).

\subsubsection{Igual X Parecido X Diferente}

O jogo Igual X Parecido X Diferente foi idealizado por Violeta Gainza (2009), porém foram feitas algumas adaptações na abordagem com os violoncelos. Foram apresentados aos alunos três pequenos cartazes, um deles continha o sinal matemático utilizado para representar "igual", outro continha o sinal matemático utilizado para representar "diferente" e outro continha um sinal criado para representar "parecido". Os alunos foram dispostos em meia lua. O primeiro aluno criou uma frase musical livremente. Em seguida, foi apresentado ao segundo aluno um dos cartazes e ele executou uma nova frase, relacionada à primeira, conforme a orientação contida no cartaz. Logo após, o mesmo aconteceu com o terceiro aluno, que variou ou manteve a frase do segundo aluno conforme a indicação do cartaz oferecido a ele, e assim sucessivamente, até que todos os alunos participaram do jogo.

Após essa rodada do jogo, um dos alunos foi escolhido para ser o maestro. Nessa rodada, além de escolher o cartaz que seria oferecido, o maestro escolheu também qual colega executaria a nova frase. As anotações no Diário de Campo apontam para o fato de que a execução desse jogo foi importante, pois foi possível trabalhar junto aos alunos, aspectos que me provocaram apreensão em jogos anteriores, como por exemplo, a qualidade de escuta. Algumas anotações enfatizam as novas perspectivas que os jogos proporcionaram.

A realização do jogo motivou as alunas a prestarem atenção nas criações das colegas e a criarem suas próprias frases musicais. O jogo gerou expectativa nas alunas, pois a escolha do cartaz sempre seria uma surpresa, despertou curiosidade e interesse, pois tais escolhas dependiam dos dizeres dos cartazes e não unicamente da vontade de cada aluna (DCM, 2017, p. 12). 
Na minha percepção, este jogo possibilitou um desafio criativo às alunas. Elas foram desafiadas a criar em curto espaço de tempo, frases musicais relativas aos dizeres dos cartazes e reagiram muito bem a este desafio. Foi um jogo dinâmico e que gerou a necessidade de concentração e foco nas alunas, trabalhando a questão da qualidade da escuta (DCM, 2017, p. 12).

Dessa maneira, as anotações realizadas no Diário de Campo apontam para a ideia de que os jogos se tornaram complementares em seus objetivos e propostas. As anotações realizadas apontam que, mesmo nem sempre tendo existido a possibilidade da repetição dos jogos, a fim de proporcionar o aumento de complexidade de ideias e vivências, essa possibilidade foi contemplada durante a sucessão dos jogos. Através das minhas anotações e observações, pude constatar que os alunos acumularam as experiências vivenciadas nos jogos, utilizando-as como base para experiências e vivências futuras nos jogos subsequentes.

Essa observação condiz com algumas das ideias trazidas por Dewey (2010), que considera que as experiências significativas agregam conhecimento por meio de todo o processo vivenciado e não apenas por seu produto final (DEWEY, 2010, p. 122). De acordo com minha observação, acredito que os jogos de improvisação constituíram-se em experiências agregadoras de conhecimento para os estudantes, pois os estudantes demonstraram-se aptos e ativos na transferência dos conhecimentos recém-adquiridos para novos desafios criados pelas atividades posteriormente apresentadas.

\subsubsection{Composição com gravuras e escrita da composição com notação própria}

Esse jogo foi concebido dentro de ideiais semelhantes desenvolvidas por diversos educadores musicais. Para a sua execução foi solicitado aos alunos, na aula anterior a sua realização, que trouxessem uma ou mais fotos pessoais ou gravuras de revistas. As turmas foram divididas em dois grupos, com exceção do Instituto Fukuda, e algumas gravuras foram distribuídas entre os grupos. Foi solicitado que os alunos escolhessem uma ou quantas gravuras desejassem para contar uma história que deveria ser criada, em grupo, por eles. A indicação dada aos alunos foi que, após a criação da história, essa deveria ser contada apenas por intermédio de sons reproduzidos com os violoncelos. Os alunos, em conjunto, criaram sua história e pesquisaram alternativas sonoras para que essa história fosse contada por meio dos seus instrumentos. Posteriormente, foram distribuídas cartolinas e jogos de lápis de cor para cada um dos grupos. Os alunos deveriam escrever, com linguagem própria, a música que haviam criado. Os alunos foram estimulados a escrever sua música utilizando qualquer recurso que desejassem, como por exemplo, desenhos, símbolos, palavras, etc. Em conjunto, os alunos 
criaram a sua partitura e em seguida ensaiaram a música criada por eles. Logo após, os alunos apresentaram a sua música para o outro grupo de estudantes. As partituras elaboradas pelos alunos encontram-se disponíveis no Anexo A desta dissertação.

As anotações realizadas no Diário de Campo apontam para diferenças na execução desse jogo, dependendo do perfil dos alunos. No Instituto Baccarelli foi necessário que eu ajudasse a organização de um dos grupos de alunas, em função da sua faixa etária. Ainda assim, relembro que os resultados foram bastante satisfatórios. Tal experiência foi relatada da seguinte forma nas minhas anotações:

Prosseguimos com a atividade da Composição com gravuras. O objetivo do encontro de hoje era que as alunas treinassem a sua peça e apresentassem às colegas do outro grupo. Chegou o momento da apresentação. Cada grupo contou a sua história em voz alta, para isso foi escolhida uma aluna de cada grupo e logo após tocaram sua peça às colegas. $\mathrm{O}$ grupo das alunas maiores escolheu fazer uma espécie de narração durante a execução da peça, iniciativa que foi valorizada, pois existem peças de música contemporânea que se utilizam de falas e narrações por parte dos intérpretes. O grupo das alunas menores executou a sua peça também com excelente qualidade de escuta (DCM, 2017, p. 14).

Considero o silêncio mantido pelas alunas de ambos os grupos durante as execuções como um elemento de grande progresso na qualidade de escuta desde o início do trabalho, pois as alunas tinham uma característica de expressar-se verbalmente durante a execução da maioria dos jogos. Neste momento de finalização do trabalho, elas conseguiram expressar-se apenas pelo seu instrumento (DCM, 2017, p. 14).

Através das anotações, considero que esse jogo foi importante para que os alunos adquirissem sua própria dinâmica de organização, desenvolvendo autonomia e diálogo. Esse apontamento está em consonância com algumas ideias de Koellreutter trazidas também por Brito (2017). Segundo os relatos de Brito (2017), é importante que os alunos estabeleçam, conforme sua percepção do silêncio, os tempos de início e de final das improvisações, bem como a duração das suas intervenções, sendo esses pontos, indicadores do seu pensamento musical.

\subsubsection{Improvisação com Ostinato}

O jogo intitulado Improvisação com ostinato foi aplicado apenas no Instituto Baccarelli. As alunas foram distribuídas em meia lua e foi explicado a elas o que era um ostinato. Em seguida foi escolhido um ostinato rítmico, com o qual as alunas já eram familiarizadas, e foi solicitado que todas executassem esse ostinato utilizando a corda solta ré do violoncelo com pizzicato. Foi proposto que uma das alunas seria a solista, enquanto as outras 
alunas manteriam o ostinato. A aluna solista poderia executar frases musicais utilizando diferentes maneiras de produção sonora. Quando terminasse o seu solo, a aluna solista deveria fornecer alguma indicação às demais colegas e a próxima aluna passaria a adotar o papel de solista. Esse jogo foi executado algumas vezes, até que todas as alunas pudessem ter participado mais de uma vez no papel de solistas.

As alunas utilizaram em suas improvisações elementos técnicos e musicais que já estavam familiarizadas. Relembro que associei a experiência vivenciada no jogo com algumas considerações de Violeta Gainza (2009).

Foi interessante analisar como as alunas se utilizaram de conhecimentos já aprendidos, como a "descida dos dedos" para compor as suas melodias. Este fato nos leva a confirmar a colocação de Violeta Gainza de que as improvisações podem e devem ser usadas para a fixação de conteúdos técnicos trabalhados (DCM, 2017, p. 15).

Segundo Gainza (2009), um dos objetivos da improvisação é a fixação de elementos técnicos já abordados com os alunos. A autora enumera mais três objetivos, entre eles, "a consolidação da técnica instrumental ${ }^{14 "}$ (GAINZA, 2009, p. 25, tradução nossa). Segundo minhas observações e anotações as alunas utilizaram, então, os jogos, para consolidar elementos técnicos abordados em momentos precedentes e agregando a eles significação musical.

Como autocrítica, em minhas observações considerei que, assim como ocorreu em outros momentos da pesquisa, as alunas poderiam ter sido estimuladas a praticar maior variação em suas criações, tornando a experiência mais rica, sendo estimuladas a utilizarem elementos como variações de métrica, de dinâmica, de velocidades de execução, entre outros.

\subsubsection{A Floresta Encantada}

Criado por Claudia Freixedas para flautas doces e adaptado para grupos de violoncelos, esse jogo foi selecionado inicialmente para ser aplicado nas instituições. Por questão de tempo, não foi possível a sua aplicação. Consiste em uma variação do jogo $A$ noite no Castelo, com um acréscimo de complexidade. Nesse caso, também se cria, em conjunto com os alunos, uma história na qual dois exploradores chegam a uma floresta encantada. Nessa floresta, cada árvore emite um som diferente. Quando os exploradores se aproximam das árvores, elas emitem o seu som. Pode se realizar esse jogo com os olhos abertos ou vendados,

\footnotetext{
${ }^{14}$ El afianzamiento de la técnica instrumental (GAINZA, 2009, p. 25).
} 
de forma semelhante à do jogo A noite no Castelo e as árvores podem emitir um único som ou diferentes sons, conforme o contexto musical.

Nesse jogo, uma das complexidades a serem apresentadas aos alunos é que mais de um explorador entra na floresta ao mesmo tempo. Tal característica proporcionará a existência de um diálogo a ser "composto" pelos exploradores, que também atuarão como maestros.

\subsubsection{Passeio no zoológico}

Esse jogo foi criado por Violeta Gainza e selecionado previamente para ser aplicado nas três instituições. Assim como o que ocorreu no jogo anterior, por questão de distribuição de tempo, não foi possível a sua aplicação. A ideia do jogo é que se crie, em conjunto com os alunos, uma história, dessa vez, de um visitante em um zoológico. O visitante passeia pelo zoológico e observa os diferentes animais. Cada aluno escolhe um animal para representar com seu violoncelo. O visitante escolhe qual animal quer visitar se posicionando na frente de cada um dos colegas que o estará representando.

Nesse jogo, pode-se acrescentar a interação do visitante com os animais. Conforme essa interação ocorra, o animal pode se manifestar com diferentes caracteres musicais, utilizando diferentes dinâmicas, articulações, ritmos, nuances timbrísticas ou organização dos conteúdos em forma de frases musicais.

\subsubsection{Os pássaros e o Caçador}

Assim como aconteceu com os dois jogos anteriormente citados, esse jogo foi selecionado, mas não foi possível sua aplicação junto aos alunos. Esse jogo foi criado tendo como inspiração um jogo denominado Os pássaros e o gavião, elaborado pela educadora Claudia Freixedas. Nesse jogo, pergunta-se aos alunos quais sons de pássaros eles conhecem. Esses sons podem ser inventariados coletivamente, ou pode se propor aos alunos que investiguem individualmente em suas casas e tragam os resultados das suas investigações para apresentar aos demais colegas. Dessa forma, são escolhidos alguns pássaros que se desejam imitar e são procuradas sonoridades semelhantes por meio dos violoncelos.

Após a escolha dos sons dos pássaros, cada aluno se torna responsável pela emissão de um desses sons, representando uma espécie de pássaros. Em seguida, é escolhido, em conjunto, um som representativo, que imite o som produzido pelo caçador. Propõe-se então que, na mata onde se encontram os pássaros, cada um deles atue de forma a dialogar com os demais, criando 
conscientemente um contexto sonoro. Um aluno será responsável por emitir o som do caçador. Ao ser ouvido o som do caçador, os pássaros devem fazer silêncio. Em seguida, os pássaros, pouco a pouco, voltam a cantar, novamente estabelecendo um diálogo com os demais pássaros da mata. $\mathrm{O}$ caçador pode intervir na mata o número de vezes que desejar e com a frequência que desejar. Pode se dar autonomia para que o próprio grupo sinta o tempo necessário de silêncio após cada intervenção do caçador, o momento de iniciar a improvisação e o momento de finalizá-la.

\subsection{CONSIDERAÇÕES DOS ESTUDANTES SOBRE AS AULAS}

Partindo da proposta de uma abordagem qualitativa, os alunos que participaram das atividades foram convidados a dar suas opiniões em relação aos jogos de improvisação realizados. Assim como já exposto em capítulo anterior, foi solicitado que cada estudante relatasse suas ideias e percepções a respeito de cada jogo, ao final de cada encontro. Os alunos recebiam material para escrever ou desenhar, para assim expressarem seus pensamentos e considerações sobre as atividades. Além dos relatos individuais, ao final de todas as atividades, os alunos responderam a um questionário.

Como mencionado anteriormente, os questionários continham dez questões de múltipla escolha, com respostas que variavam entre sim, mais ou menos e não. As respostas dos questionários foram tabuladas e organizadas em gráficos, que foram anexados aqui, para que assim pudessem ser melhor visualizadas. Apesar da abordagem analítica estar configurada como qualitativa, a análise numérica das respostas é interessante por proporcionar uma visão geral das percepções dos alunos sobre as atividades, que são confirmadas ou não pelas anotações feitas por eles. Sendo assim, apresento algumas das ideias trazidas pelos alunos, relacionando-as com a literatura consultada como referência e com minhas próprias percepções e observações.

A primeira questão trazida pelos questionários teve como intenção observar se os alunos se sentiam confortáveis durante a prática dos jogos de improvisação. Tal questão visava contemplar tanto aspectos de ordem musical quanto de ordem técnica. A maioria dos alunos respondeu que se sentiu confortável durante a prática dos jogos de improvisação. As respostas dadas a essa pergunta variaram entre o sim, dezoito respostas, e o mais ou menos, seis respostas (Gráfico 1). 
Gráfico 1- Respostas dos alunos em relação ao conforto durante os jogos

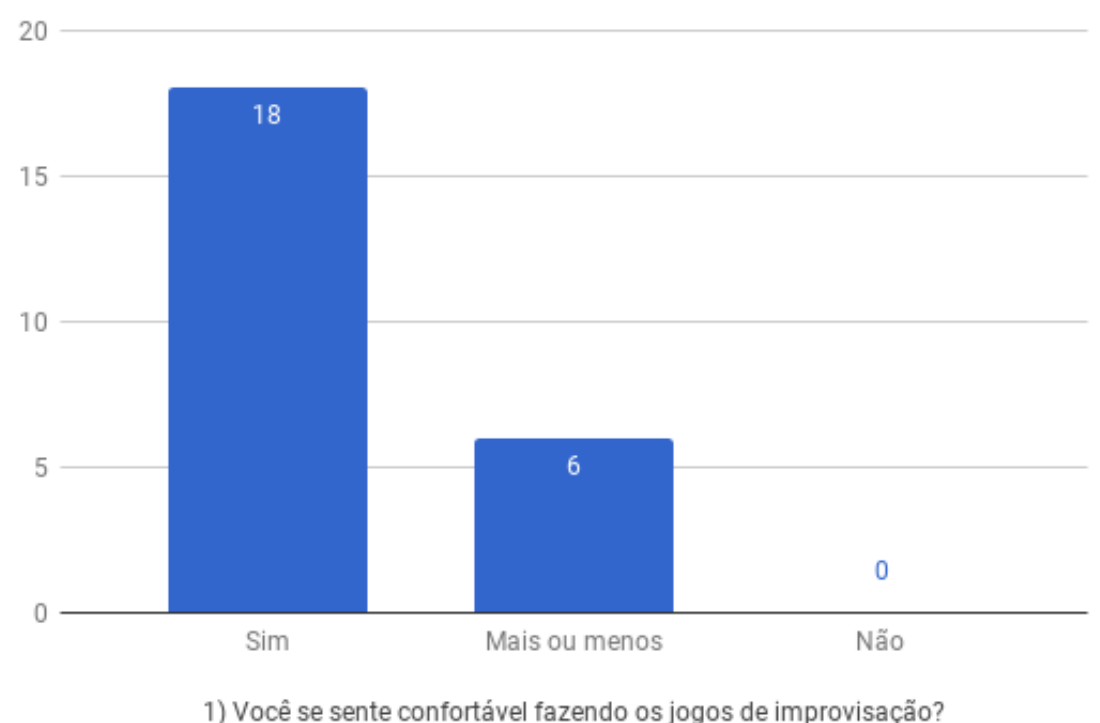

Fonte: elaboração da própria autora

Um dos alunos fez um comentário em seu questionário, ao lado da questão, justificando a resposta dada como mais ou menos. Nesse comentário, o aluno explicava que sentia um pouco de vergonha de tocar sozinho na frente dos colegas. Sendo assim, considero que a questão ultrapassou o objetivo inicial, pois também foi respondida, pelo menos por esse aluno, levando em consideração aspectos de ordem social e psicológica.

A colocação feita pelo aluno, ao justificar sua resposta, me leva a questionar algumas abordagens destinadas ao ensino do instrumento e possíveis maneiras de relacionamento dos alunos com essas abordagens. Em algumas delas, é esperado do aluno que ele atinja determinado "resultado musical", baseado em alguma concepção anterior, como uma gravação ou mesmo a performance do professor, sendo que essas são usadas como referência interpretativa e musical. Observo que a ideia de "alcançar metas e resultados" é, frequentemente, utilizada por diferentes esferas sociais, entre elas, algumas práticas relacionadas ao ensino e aprendizagem, mantendo o indivíduo em estado de competição (com os outros ou consigo mesmo) e estresse. Algumas propostas de ensino musical também adotam tal abordagem como ponto de partida para o trabalho de interpretação e de formação instrumental, colaborando para o que, segundo os estudos de Fonterrada (2008), promove a "tendência ao individualismo" (FONTERRADA, 2008, p. 81). Dessa forma, o aluno pode se sentir em constante exposição e com alto nível de cobrança.

Em contrapartida, as atividades de improvisação coletiva, que incentivam a livre criação e dissolvem a ideia de "erro", caminham no sentido oposto a esta tendência, humanizando a aula de instrumento musical e desvinculando-a da ideia exclusiva de "formação 
de músicos". A dissolução da ideia de "erro", trazida por pesquisadores como Alonso (2007), está em consonância com as ideias contempladas por Dewey (2010). Dewey acreditava que a experiência promovia a aprendizagem, não apenas pelo resultado (ou produto), mas por todo o processo vivenciado (DEWEY, 2010, p. 122). Sendo assim, ambos, "acertos" e "erros", fazem parte do processo de experimentação e construção da bagagem musical do aluno e perdem sua identidade e importância enquanto elemento de comparação.

Acredito que, durante essa pesquisa, a ideia de que não existe o "erro", em se tratando de jogos ligados às concepções de livre improvisação, não foi completamente vivenciada pelos alunos. Acredito que a manifestação de um sentimento de vergonha, relatado pelo aluno, conforme citado, pode estar ligada a concepções de ensino que enfatizam a comparação entre os sujeitos e a autoexposição crítica e que essa concepção pode ter sido trazida pelos estudantes também para os jogos de improvisação. Considero que tal ideia seria melhor vivenciada nesse trabalho se o vínculo entre professor e alunos pudesse ter sido estabelecido com maior propriedade, reforçando a autoconfiança e a confiança no grupo. Infelizmente não foi possível um trabalho com maior duração, a fim de estabelecer vínculos mais sólidos entre os alunos e entre os alunos e professor. Como autocrítica ao trabalho vivenciado, considero que os fatos apontados possam ter proporcionado uma experiência diversa da que seria experimentada em um processo com maior duração e com vínculos mais fortemente estabelecidos.

A segunda questão trazida pelo questionário perguntava aos alunos se eles consideravam o violoncelo como veículo de expressão pessoal, tornando-o sua voz durante os jogos. De forma semelhante ao que ocorreu nas respostas relativas à primeira questão, a maioria dos alunos considerou que o violoncelo pode expressar os conteúdos internos de cada um. As respostas obtidas pelos questionários foram quinze respostas para o sim e nove para o mais ou menos (Gráfico 2). 
Gráfico 2- Respostas dos alunos em relação à apropriação do violoncelo como veículo de expressão pessoal

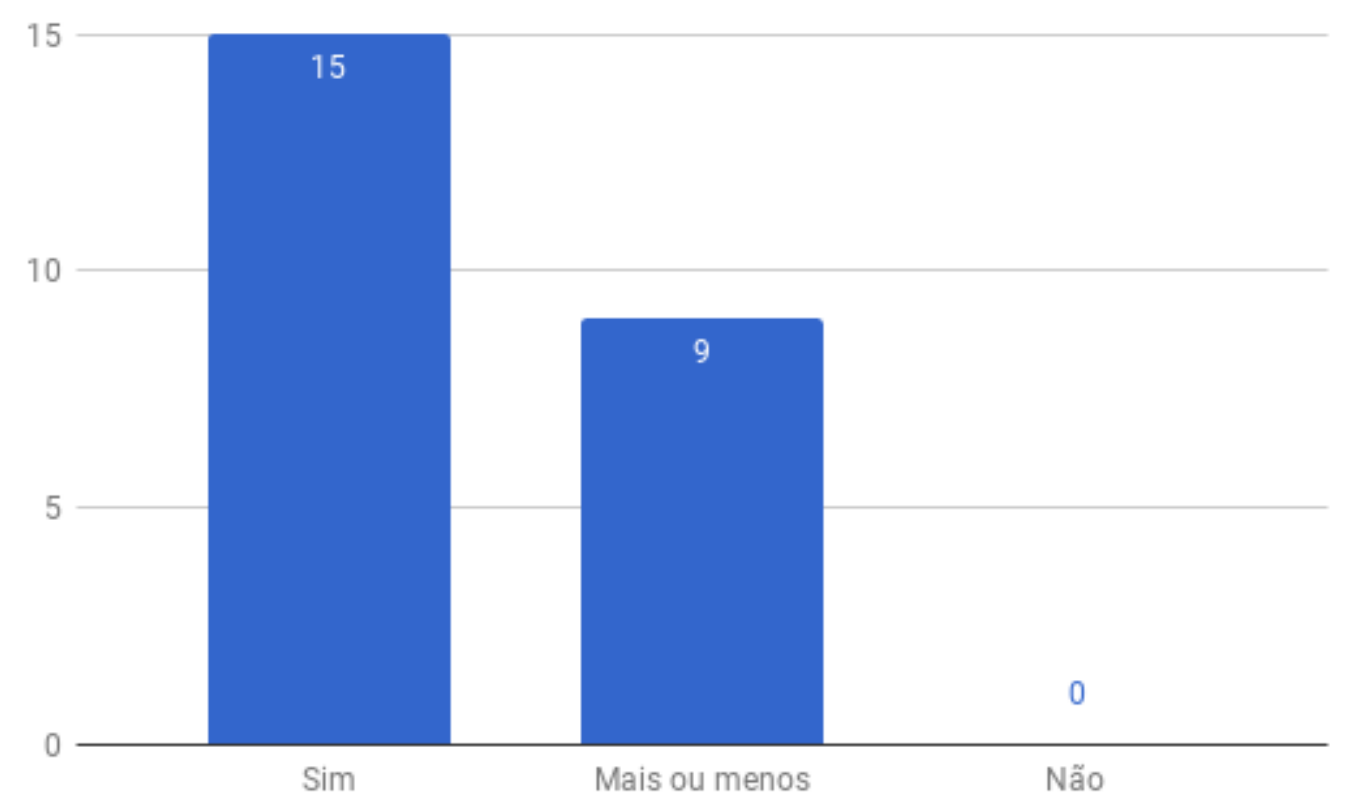

2) Você acha que o violoncelo consegue "falar" por você durante os jogos de

Fonte: elaboração da própria autora.

Em seus relatos individuais, os alunos apontaram algumas ideias, como por exemplo, a possibilidade de tocar o que "estava na cabeça", e a forma como a música consegue expressar conteúdos variados, como por exemplo, conteúdos relativos à descrição de uma imagem. Algumas dessas colocações são relatadas nas falas:

Achei legal porque toquei o que estava na minha cabeça e não tinha que decorar a música (CAA, 2017, p. 7, aluno do Instituto Baccarelli).

Gostei muito desse em especial pela forma como a música expressa o que a imagem mostra (CAA, 2017, p.11, aluno do Projeto Guri-Polo de Indaiatuba).

Essas ideias trazidas pelos estudantes dialogam com as ideias, mencionadas anteriormente, de alguns pensadores e educadores, como Matthews (2012) e Alonso (2007). A improvisação é ressaltada por esses pesquisadores como uma possibilidade de manifestação dos conteúdos pessoais dos sujeitos envolvidos, mobilizando e expressando musicalmente, tendências de comportamento, manifestações de sentimentos e de pensamentos. Wade Matthews (2012) ressalta esse aspecto da improvisação quando a considera como um "fenômeno social" (MATTHEWS, 2012, p. 61), apontando para o fato de que as personalidades dos improvisadores aparecem com nitidez durante uma prática de improvisação coletiva (MATTHEWS, 2012, p. 61). Em associação com essas ideias, durante o trabalho da pesquisa de campo, pude observar que os jogos de improvisação coletiva, muitas vezes, reproduziam 
conflitos e situações da vida diária, mobilizando algumas ações por parte dos alunos. Tal elemento também é destacado por Alonso (2007) quando a autora aponta que um dos valores da improvisação é "apresentar desafios semelhantes aos da vida cotidiana" (ALONSO, 2007, p. 57).

Outro aspecto levantado pelos estudantes diz respeito à questão da obrigação de decorar a música. Acredito que essa é uma crítica direta aos métodos de ensino que enfatizam esse processo como o único viável para a aprendizagem instrumental. Acredito que o aluno que trouxe esse apontamento considerou o espaço destinado aos depoimentos sobre os jogos como um momento no qual poderia também expressar sua opinião sobre os processos de ensino que são abordados junto a ele. Geralmente, é oferecido aos alunos pouco espaço de troca de saberes e de reflexão sobre sua própria aprendizagem nas atividades relacionadas ao ensino instrumental, sobretudo ao ensino tutorial, assim como alertou Moraes (1997), e já citado nesta dissertação. Sendo assim, considero importante que possa ser oferecido aos alunos maior espaço de reflexão e troca de experiências em relação ao seu próprio processo musical.

A terceira, quarta e quinta questões do questionário visavam compreender como os alunos classificaram os jogos, se os interpretaram como música, como brincadeira ou como exercício. A terceira questão enfatizava se os alunos compreenderam as atividades como música. De forma bastante expressiva, vinte e dois alunos consideraram os jogos de improvisação como música. Um dos alunos respondeu mais ou menos e outro aluno respondeu não. Essa questão foi a que recebeu maior incidência de respostas relativas ao sim, quase atingindo a unanimidade (Gráfico 3).

Gráfico 3- Respostas dos alunos e relação à classificação dos jogos enquanto música

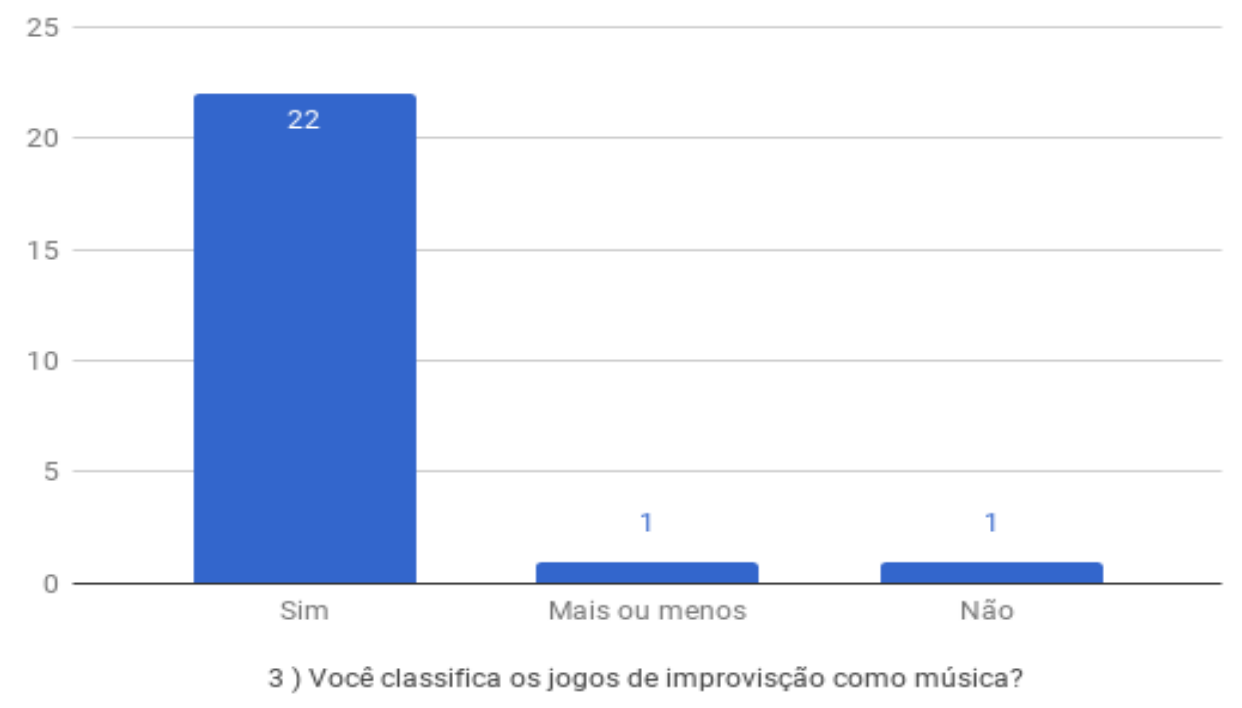

Fonte: elaboração da própria autora. 
Considero, devido à alta incidência de respostas sim, que os alunos interpretaram os jogos de improvisação como uma prática musical. Havia uma apreensão da minha parte em relação à possibilidade de que os alunos considerassem as atividades propostas como atividades de entretenimento ou passatempo, ou mesmo, como práticas obrigatórias que deveriam ser executadas por eles. Por meio das respostas fornecidas, acredito que esse fato não se confirmou. A prática de improvisação é considerada por vários autores como Alonso (2007), Matthews (2012) e Costa (2016) como o "fazer musical em tempo real". Acredito que a percepção dos alunos das atividades como música está relacionada às características desse fazer em tempo real.

Em minha percepção, considero também que os alunos puderam vivenciar as experiências dos jogos sob diferentes pontos de vista, tanto como autores quanto como espectadores. Acredito que esses diferentes estados de vivência, assim como trazido por Dewey (2010) em relação à experiência, e já tratado em capítulo anterior, possibilitaram a compreensão das características artísticas das atividades.

Outro aspecto importante a ser ressaltado é o fato de que os alunos, mesmo sem ter tido contato prévio com música contemporânea, identificaram as atividades como música, tendo em vista que as estéticas dos jogos de improvisação se assemelharam as de algumas poéticas da música contemporânea, como era um dos objetivos desse trabalho. Dessa forma, acredito que essa compreensão aponta para a ideia de que o que se considera música, conforme a tradição denominada como "prática comum" (COSTA, 2016, p. 82), é uma perspectiva que só se sustenta dentro das concepções dessa própria tradição e não mais sob os parâmetros da realidade contemporânea. A identificação das atividades como música pelos alunos, sinaliza para o fato de que a sua concepção sobre essa ideia pode estar mais próxima das experiências das estéticas das músicas dos séculos XX e XXI do que das de séculos anteriores. Essa consideração, vinculada à ideia de a arte ser um veículo do pensamento humano, reforça a necessidade da inclusão de poéticas da música contemporânea desde o início da formação musical.

$\mathrm{Na}$ fala dos alunos, destacam-se elementos que direcionam para a identificação da ideia dos jogos como música. Um dos alunos, por exemplo, relacionou a criação de uma peça musical com a junção de diferentes "motivos", ou trechos musicais menores. As palavras "motivos" e "peça" foram utilizadas por ele em sua fala, provavelmente construídas dentro de suas vivências musicais anteriores, e ressaltam a identificação que esse aluno fez entre as atividades de improvisação e atividades estruturadas como "peças musicais". 
Muito interessante para mostrar como, a partir de vários motivos, se pode integrar uma peça (CAA, 2017, p. 10, aluno do Instituto Fukuda).

A quarta questão do questionário tinha o objetivo de investigar se os alunos perceberam os jogos como brincadeira. Tal questão foi formulada levando em consideração a possibilidade de os alunos perceberem ou não as características lúdicas presentes nas atividades. A maioria dos alunos, dezesseis responderam sim e sete alunos responderam mais ou menos, considerou os jogos de improvisação como brincadeira (Gráfico 4).

Gráfico 4-Respostas dos alunos em relação à classificação dos jogos enquanto brincadeira

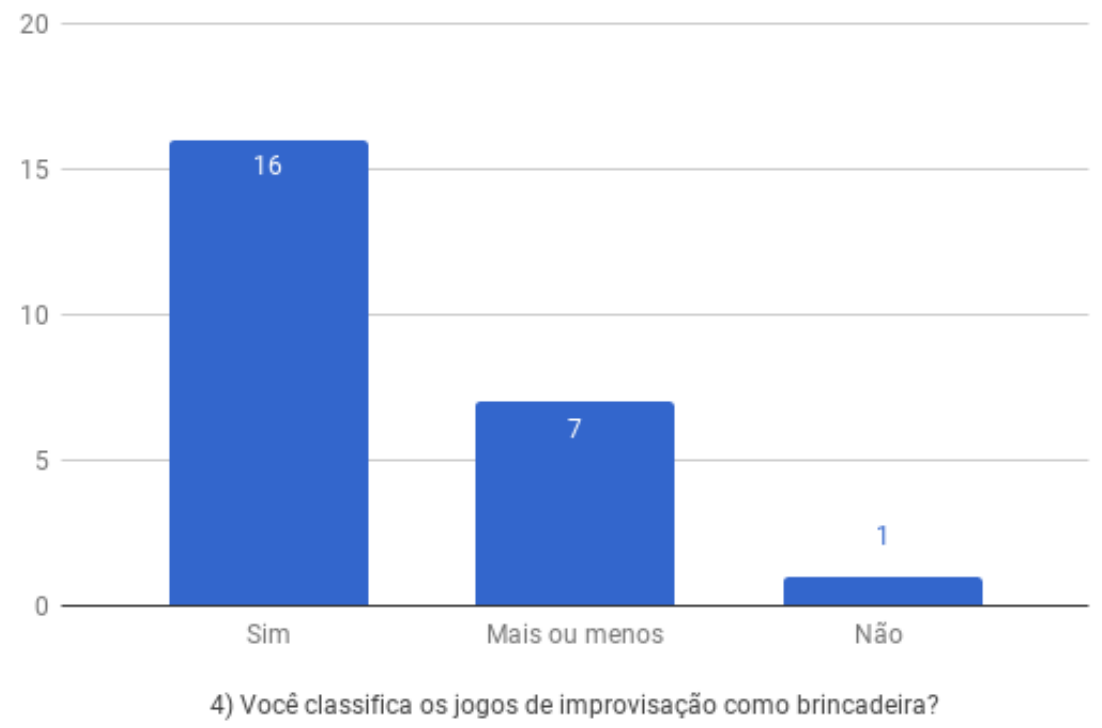

Fonte: elaboração da própria autora.

Pode-se observar, comparativamente com a questão anterior, que para os alunos, um tipo de classificação não exclui o outro. Sendo assim, considero que os alunos tiveram percepções múltiplas a respeito dos jogos. Algumas falas trazidas pelos alunos em seus depoimentos individuais, com frequência, usavam adjetivos como "legal" e "divertido", o que, no meu entender, ressaltam algumas das qualidades lúdicas das atividades. Assim, considero que, de maneira similar ao proposto por Huizinga (2000), adotado também por Chateau (1987), Swanwick (2006) e Delalande (2001), e já apresentado em capítulo anterior, os alunos consideraram música e jogo como atividades correspondentes, ou com características similares. Algumas falas dos alunos são trazidas em seguida e apontam para as ideias de brincadeira, jogo e ludicidade. prestar muita atenção até chegar a sua vez (CAA, 2017, p. 7, aluno do Projeto Guri-Polo de Indaiatuba). 
Muito legal. Boa brincadeira, principalmente para iniciantes, estimula criatividade e muito o ouvir e tocar em seguida (CAA, 2017, p. 5, aluno do Projeto Guri-Polo de Indaiatuba).

Eu achei todos legais: porque você aprende e se diverte (CAA, 2017, p. 12, aluno do Projeto Guri-Polo de Indaiatuba)

Um apontamento também foi feito através de desenhos (Figura 2).

Figura 2- Desenho de um aluno em relação aos jogos desenvolvidos.

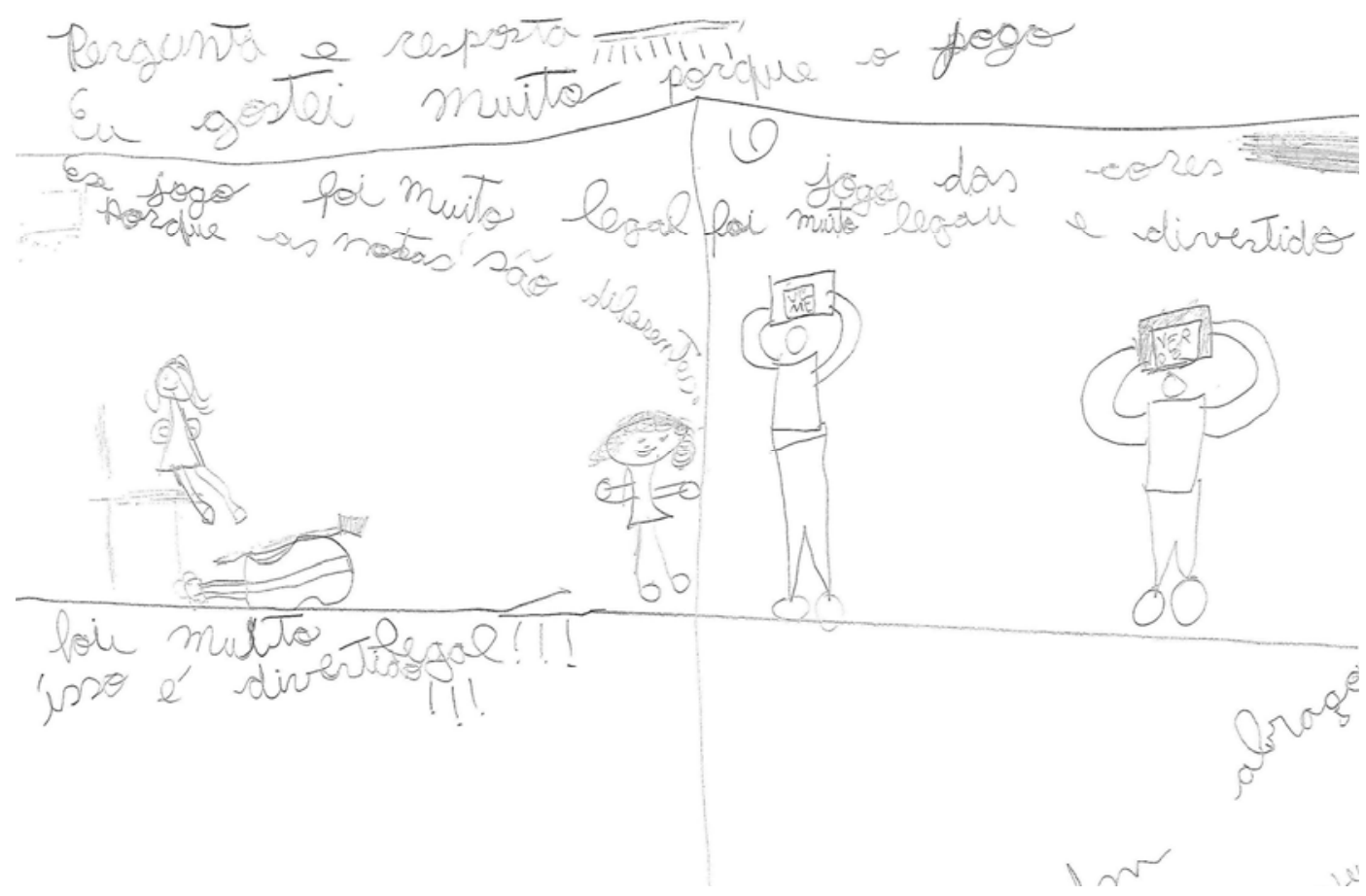

Fonte: CAA, 2017, p. 13, aluno do Instituto Fukuda.

Pelos depoimentos trazidos e por minha percepção durante o trabalho de pesquisa de campo, acredito que os alunos, ao considerarem as atividades como brincadeira, valorizaram a brincadeira enquanto prática pedagógica. Descarto, assim, novamente, a possibilidade de que os alunos tenham considerado "brincadeira igual a passatempo", por terem sido ressaltadas nas mesmas falas elementos como jogo e atenção, brincadeira e criatividade ou aprender e divertir. Sendo assim, considero que os jogos conseguiram alcançar o "equilíbrio" ressaltado por Kishimoto (2013). A autora esclarece que os jogos com função pedagógica estão relacionados com a presença concomitante de duas funções: a função lúdica e a função educativa.

O equilíbrio entre as duas funções é o objetivo do jogo educativo. Entretanto, o desequilíbrio provoca duas situações: não há mais ensino, há apenas jogo, quando a função lúdica predomina ou, ao contrário, quando a função educativa elimina todo o hedonismo, resta apenas o ensino (KISHIMOTO, 2013, p. 19). 
A quinta questão tinha o objetivo de verificar se os alunos consideraram os jogos como exercício. A palavra exercício foi utilizada por ser também, frequentemente, associada com propostas relacionadas à aprendizagem de habilidades técnicas instrumentais, por intermédio da repetição. A grande maioria dos alunos classificou os jogos de improvisação como exercício. Vinte alunos responderam sim, três alunos responderam mais ou menos e um aluno respondeu não (Gráfico 5).

Gráfico 5- Respostas dos alunos em relação a classificação dos jogos enquanto exercício

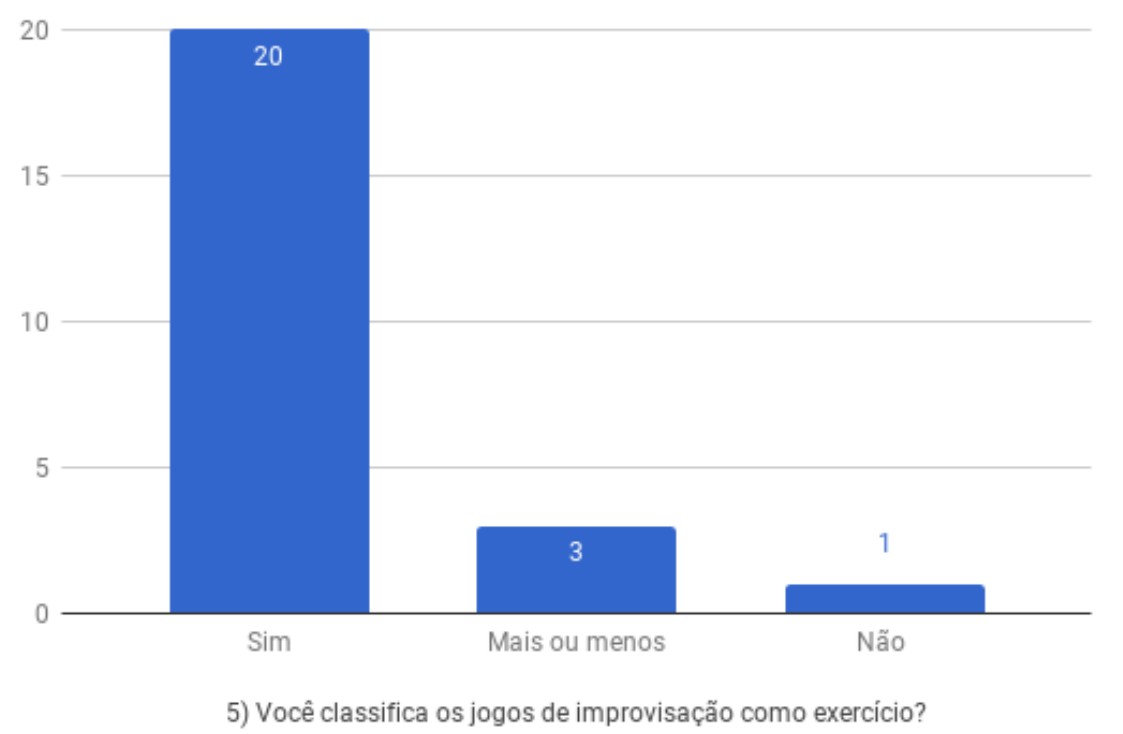

Fonte: elaboração da própria autora.

Como mencionado anteriormente, os alunos tiveram percepções múltiplas a respeito dos jogos. As respostas dadas a essa questão são, aparentemente, contraditórias com as respostas dadas às questões anteriores, relativas à percepção das atividades como música e/ou brincadeira. Por outro lado, ao analisar algumas considerações dos alunos em seus relatos individuais, acredito que as respostas dadas por eles, relacionando os jogos a exercício, podem estar vinculadas ao fato da sua percepção das atividades como uma proposta "séria", tanto quanto é considerada, de maneira geral, a formação técnica, por exemplo. Alguns alunos destacaram algumas características dos jogos como atividade "séria", ao compará-los a um concerto, por exemplo, ou a ressaltar a necessidade de manter a atenção durante a atividade, como se pode ver em algumas de suas falas:

Gostei porque pude trabalhar em equipe, como se estivesse em um concerto (CAA, 2017, p. 6, aluno do Projeto Guri-Polo de Indaiatuba).

Muito bom, ajuda a pessoa aprender a ficar mais atenta, e também ajuda na audição musical (CAA, 2017, p. 7, aluno do Projeto Guri-Polo de Indaiatuba). 
Porém, acredito que a consideração dos alunos, trazida pelos questionários, merece atenção, com o intuito de, em momentos futuros, ser reforçada a necessidade de se manter uma escuta atenta durante os jogos, fugindo do que poderia ser a "repetição do mesmo". Como foi apontado em meu Diário de Campo e transcrito anteriormente, em alguns momentos, eu também tive a impressão de que os alunos poderiam estar concebendo os jogos como um processo mecânico, como por exemplo, "mostrar cartazes aos colegas", deixando de lado a atenção na escuta.

A sexta questão do questionário perguntou aos alunos se eles consideraram que os jogos de improvisação auxiliam na aprendizagem do violoncelo. Quatorze alunos responderam sim e dez alunos responderam mais ou menos (Gráfico 6).

Gráfico 6-Respostas dos alunos em relação a possibilidade dos jogos serem facilitadores da aprendizagem do violoncelo

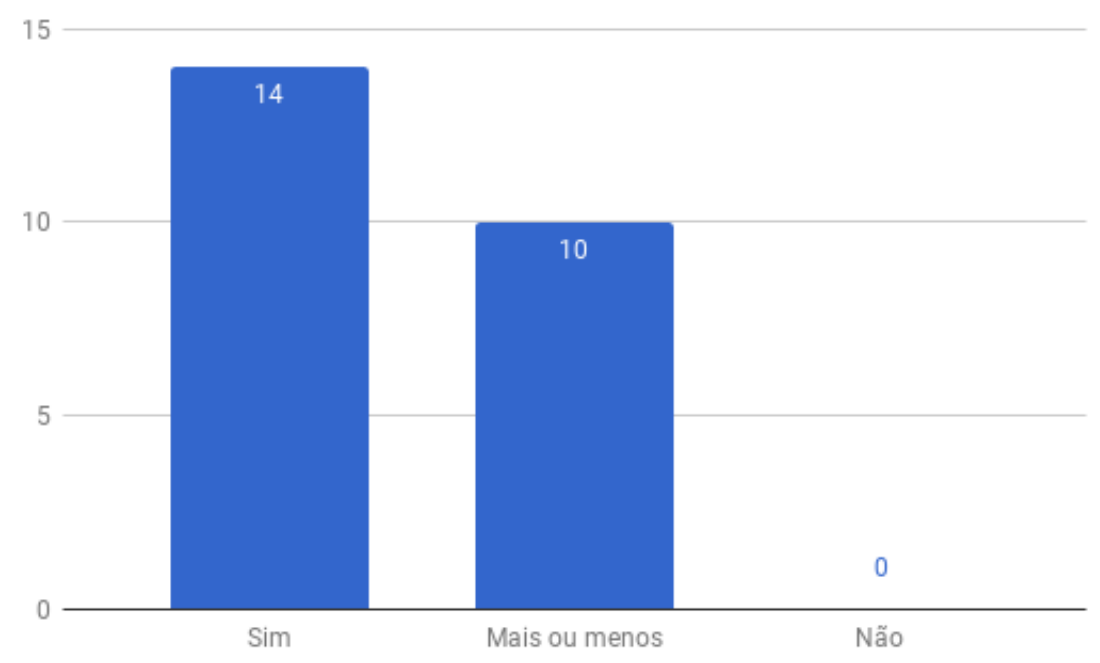

6) Você acha que os jogos de improvisação ajudam você a tocar violoncelo?

Fonte: elaboração da própria autora.

Em minha opinião, as respostas dadas pelos alunos apontam para o fato de que, como a maioria das aulas de instrumento segue um modelo conservatorial, é difícil que os alunos considerem parte da aprendizagem, abordagens que fujam desse modelo. Acredito que, mesmo entre os alunos iniciantes ou de nível intermediário de desenvolvimento instrumental, essa concepção já é fortemente estabelecida pela tradição musical na qual a maioria das escolas e centros de ensino estão inseridos. Conforme analisado por Moraes (1997) e já citado nesse trabalho, a maioria dos professores ainda utiliza a maneira tutorial e conservatorial de ensino como única estratégia pedagógica (MORAES, 1997, p. 72). Fonterrada (2008), assim como Moraes (1997), destaca que o modelo conservatorial do século XIX continua popular e vigente 
em grande parte das propostas destinadas à aprendizagem de um instrumento musical (FONTERRADA, 2008, p. 81).

Em contrapartida à essa interpretação sobre as respostas dadas nos questionários, um aluno relatou em suas anotações que a sua percepção sobre o violoncelo, a partir da execução dos jogos, ampliou-se, descrevendo o instrumento como "muito mais viável”. Tal colocação aponta para a possibilidade de que os jogos, para esse aluno, facilitaram a compreensão do funcionamento geral do violoncelo, o que considero parte do processo de aprendizagem instrumental.

Em relação a Assinatura Musical posso dizer que foi muito bacana e realmente interessante, pois vi que o cello é um instrumento muito mais viável, ou seja, é possível fazer muitos sons além do tradicional (CAA, 2017, p. 7, aluno do Projeto Guri-Polo de Indaiatuba).

Essa consideração vem ao encontro das ideias da educadora Violeta Gainza (2009). Gainza (2009) sugere que uma das características da improvisação é proporcionar a aproximação dos alunos com o instrumento, e por seu intermédio, com a música (GAINZA, 2009, p. 25).

A sétima pergunta do questionário indagava aos alunos se eles consideraram que os jogos proporcionaram integração entre os colegas de classe. De forma bastante expressiva, os alunos responderam a essa questão considerando que os jogos de improvisação auxiliam a integração entre os colegas de classe. Vinte e um alunos responderam sim e três alunos responderam mais ou menos (Gráfico 7).

Gráfico 7- Respostas dos alunos em relação aos jogos enquanto promotores da integração entre os alunos

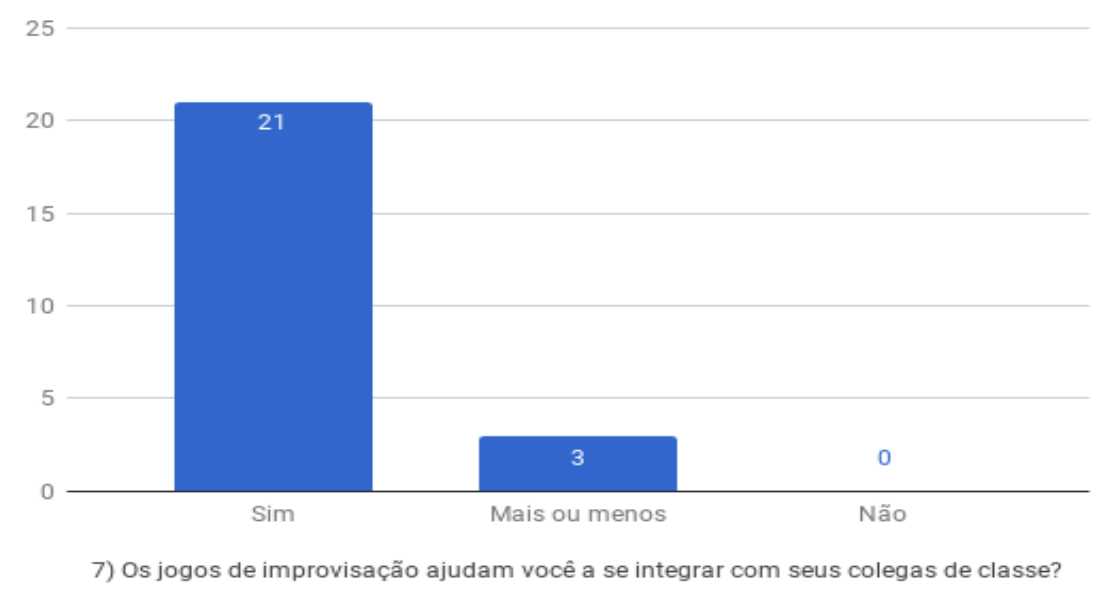

Fonte: elaboração da própria autora. 
Por meio das respostas dos alunos, acredito que os jogos de improvisação cumprem o papel de desenvolver a sociabilidade, o diálogo, a comunicação e a troca de experiências entre os sujeitos. Tais conteúdos são observados como importantes para a construção do ser humano como indivíduo, e ressaltadas como qualidades do ensino coletivo de instrumento. Conforme já citado, Tourinho (2007) acredita que por intermédio do ensino coletivo "é possível compartilhar conhecimento, espaço, e que a interação e a diferença são partes importantes do aprendizado" (TOURINHO, 2007, p. 1). Sendo assim, considero que essas características puderam ser contempladas durante a realização dos jogos.

Algumas falas dos alunos exemplificam algumas ideias desenvolvidas por eles sobre os jogos de improvisação, relativas ao trabalho em grupo.

Trabalho em equipe, desenvolvimento de novas ideias, ensina a criar visando tempos e ajuda a entender o quanto uma partitura é importante (CAA, 2017, p. 8, aluno do Projeto Guri-Polo de Indaiatuba).

Gostei porque pude trabalhar em equipe, como se estivesse em um concerto (CAA, 2017, p. 6, aluno do Instituto Fukuda).

A próxima questão perguntava aos alunos se, por meio dos jogos de improvisação, eles puderam compreender como se cria uma música. As respostas à essa questão foram vinte respostas sim e quatro respostas mais ou menos (Gráfico 8).

Gráfico 8- Respostas dos alunos em relação a possibilidade dos jogos auxiliarem na compreensão do processo de composição musical

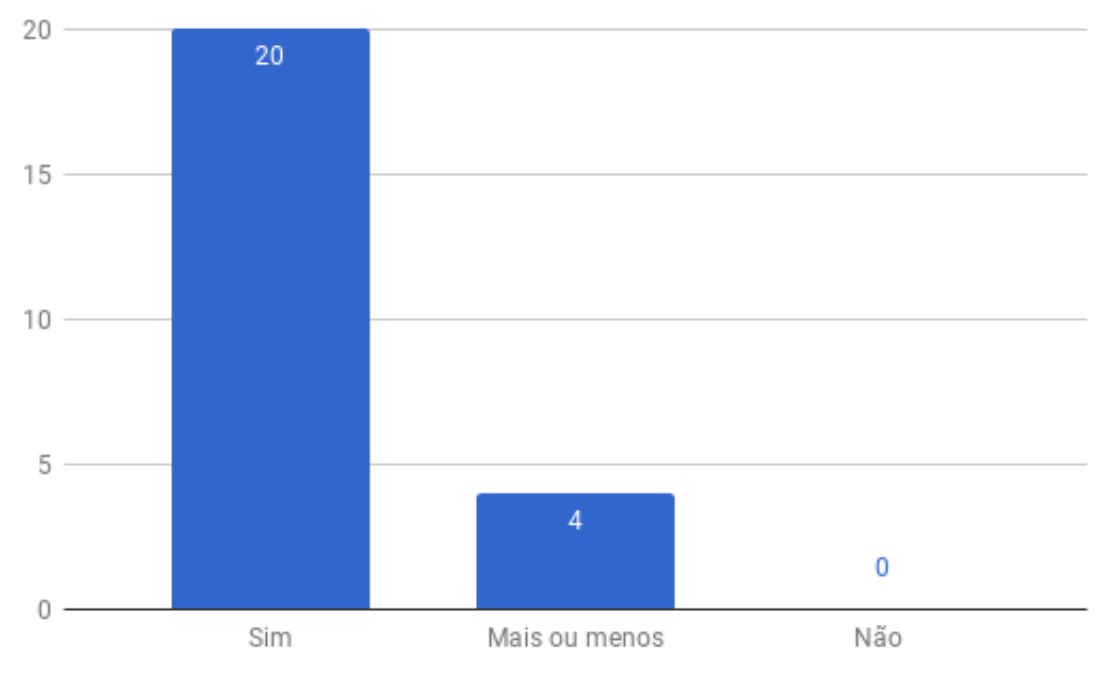

8) Os jogos de improvisação ajudaram você a entender melhor como se cria uma

Fonte: elaboração da própria autora.

Considero que as respostas dadas pelos alunos vêm ao encontro de concepções já apontadas pelos pesquisadores como Matthews (2012), Costa (2016) e Delalande (2001). Essas 
concepções enfatizam que as práticas de improvisação, além de desenvolverem as habilidades criadoras dos participantes, também proporcionam a aproximação entre intérpretes e compositores, por desmistificam a ideia de que o compositor, ou o criador musical, é uma pessoa com habilidades especiais, diferente da "pessoa comum".

Costa (2017), por exemplo, levanta esse importante aspecto, que ele denomina de “empoderamento do performer" (COSTA, 2017, p. 79). Segundo Costa (2017), “o improvisador é um performer-criador num contexto em que ocorre a eliminação (total ou parcial) das hierarquias e das fronteiras entre compositor e intérprete. E, nesse caso, a palavra 'intérprete' deixa de ser adequada" (COSTA, 2017, p. 79).

Nesse sentido, as respostas dos alunos coincidem também com minha observação durante a pesquisa de campo. Nessa observação, pude notar que os alunos vivenciaram o que foi considerado, de maneira análoga as ideias de Costa (2017), como "empoderamento criativo", situações onde os sujeitos puderam expressar-se criativamente, aproximando-se da atitude de criação, geralmente relegada aos compositores. Além desse aspecto, nos seus depoimentos pessoais, os alunos destacaram como presentes nos jogos de improvisação, elementos possíveis de tornarem-se parte de uma criação musical, como por exemplo, as ideias de "motivos" e de "conversa musical". Esses elementos também fazem parte do repertório de possibilidades, tanto dos compositores, quanto dos improvisadores.

Muito interessante para mostrar como, a partir de vários motivos, se pode integrar uma peça (CAA, 2017, p. 10, aluno do Instituto Fukuda).

Acho que este jogo ajuda a exercitar a criatividade por propor uma conversa sem palavras, através do violoncelo (CAA, 2017, p. 9, aluno do Instituto Fukuda).

A nona questão perguntava aos alunos se os jogos de improvisação auxiliaram na compreensão de "músicas diferentes", que utilizam "efeitos especiais". Tais denominações foram usadas durante o trabalho de campo a fim de contextualizar a música contemporânea e as técnicas estendidas. Foi escolhida essa abordagem pela crença de que mais se aproximava da linguagem dos estudantes, principalmente, os estudantes com menor faixa etária. Vinte alunos responderam sim e quatro alunos responderam mais ou menos nas respostas relativas a essa questão (Gráfico 9). 
Gráfico 9- Respostas dos alunos em relação aos jogos proporcionarem a escuta das estéticas da música contemporânea

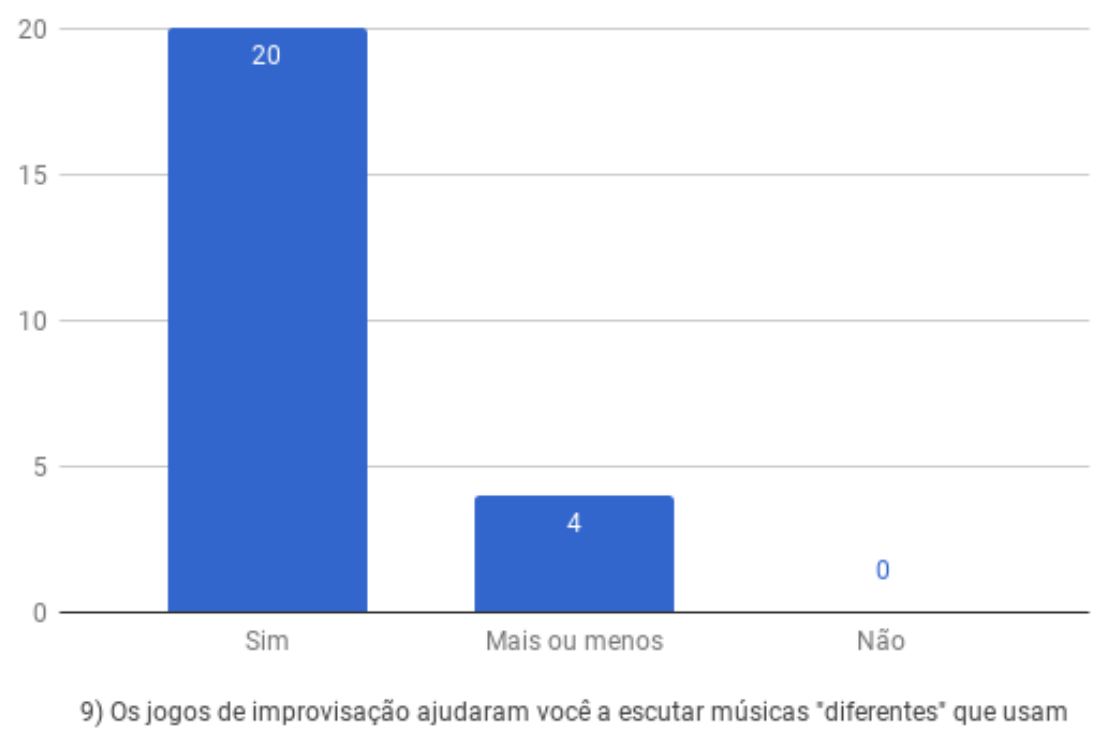

Fonte: elaboração da própria autora.

As respostas dos alunos, de maneira muito expressiva, levam-me a crer que os jogos de improvisação tiveram um papel importante na sua aproximação com as poéticas da música contemporânea. Conforme já relatado, a grande maioria dos alunos afirmou que não tinha tido contato anterior com essas poéticas. Além das respostas dos alunos, um fato em particular, ocorrido durante a pesquisa de campo no Instituto Fukuda, corrobora para essa crença. O Instituto Fukuda foi a última instituição abordada durante a pesquisa de campo. Nessa instituição, houve a oportunidade de os alunos assistirem a dois vídeos antes do final das atividades. Esses vídeos foram extraídos do site youtube e contaram, respectivamente, com uma gravação de Pression, de Helmut Lachenmann, para violoncelo solo, e de uma improvisação por senhas executada pelo grupo de violoncelos argentinos ARRE! Ao final das audições, os alunos comentaram que os intérpretes "faziam exatamente a mesma coisa que os alunos, mas com mais conviç̧ão" (aluno do Instituto Fukuda, 2017). Tal comentário aponta para a possibilidade de as atividades proporcionarem uma aproximação com as estéticas da música contemporânea, por promoverem essa identificação. Também reforça a ideia, já citada, de Delalande (2001), que ressalta a importância de oferecer aos alunos a audição de peças com construção semelhante às elaboradas por eles, para assim agregar valor às suas composições e às composições dos demais (DELALANDE, 2001, p. 146).

Ao relatar suas experiências com os novos elementos sonoros explorados, os alunos relataram em suas falas características denominadas por eles como "legais" e "boas de tocar". 
Eu amei o vermelho e o verde porque eu acho que é bom tocar outros sons (CAA, 2017, p. 9, aluno do Instituto Baccarelli).

Eu gostei bastante, porque a gente descobriu sons diferentes e alguns um tanto estranhos, mas bem legal (CAA, 2017, p. 3, aluno do Instituto Baccarelli).

A décima e última questão trazida pelo questionário tinha o objetivo de pesquisar se os alunos gostaram de tocar músicas relacionadas às poéticas da música contemporânea, ligadas ao uso de técnicas estendidas e exploração sonora do instrumento. Do total de alunos, doze responderam sim, onze responderam mais ou menos e um respondeu não (Gráfico 10).

Gráfico 10-Respostas dos alunos em relação a execução de músicas das estéticas contemporâneas

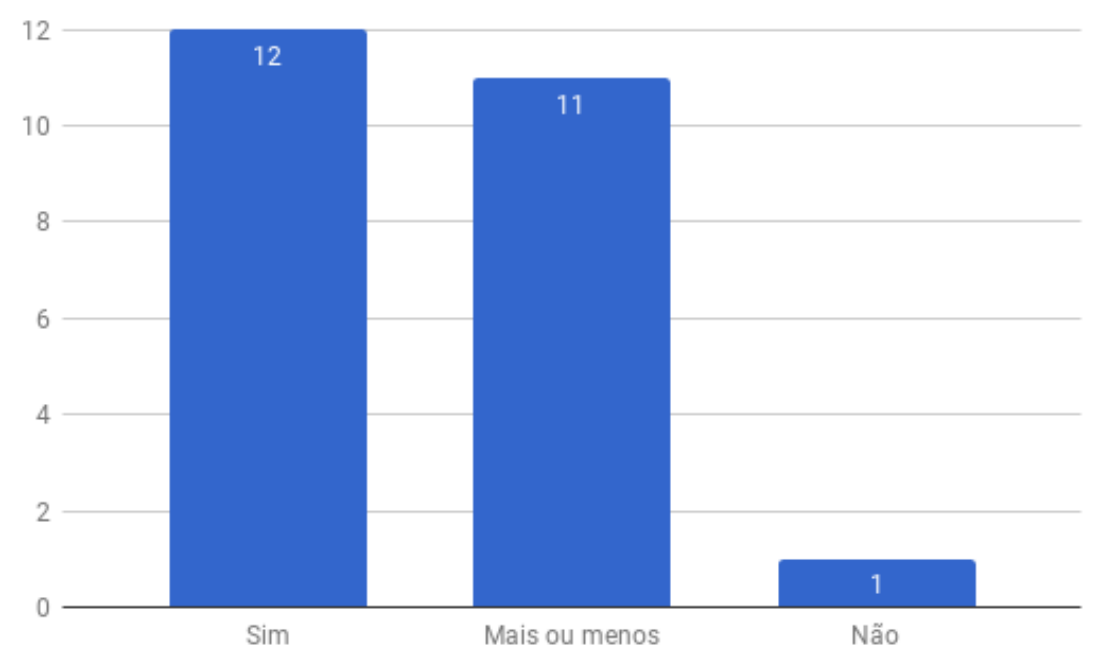

10) Vocé gosta de tocar músicas que utilizem 'efeitos especiais"?

Fonte: elaboração da própria autora.

Sob o meu ponto de vista, considero positivo o fato de a metade dos alunos ter respondido sim, e quase a outra metade ter manifestado aceitação ou abertura em relação à essa proposta, mesmo tendo sido esse, como relatado anteriormente, o seu primeiro contato com poéticas que utilizassem a produção de sons e/ou ruídos advindos do uso de técnicas estendidas. Podemos observar algumas colocações dos alunos nos apontamentos trazidos em seguida, que dizem respeito à exploração do instrumento de diferentes formas.

$\mathrm{Na}$ assinatura musical a parte de criar sons explorando o instrumento foi a melhor (CAA, 2017, p.12, aluno do Instituto Fukuda).

Durante todo o processo entramos em contato com o violoncelo de maneiras não muito usuais, o que nos abre a porta para um universo diferente de sons, expressões, sentidos e sentimentos (CAA, 2017, p. 12, aluno do Instituto Fukuda) 
Gostei bastante pelo fato de ter uma grande interação com todos os alunos e principalmente pela descoberta de sons no violoncelo (CAA, 2017, p. 12, aluno do Instituto Fukuda)

Esses apontamentos coincidem com algumas ideias de Koellreutter (1997) que considera que os jovens, desde cedo, "chegam a conhecer e, principalmente, a viver fenômenos sociais e manifestações culturais que são desconhecidos a uma grande parte dos professores, por não pertencerem à esfera de experiência destes últimos" (KOELLREUTTER, 1997, p. 40). Como exemplo dessas manifestações, Koellreutter (1997) enumera o interesse dos jovens pela improvisação e pela música moderna, que alia o som ao ruído e que "requer um novo tipo de audição e percepção e nega quase todos os conceitos da estética tradicional, linguagem musical, hoje em uso em toda a parte do mundo, no cinema, na televisão, no teatro, etc" (KOELLREUTTER, 1997, p. 40). Tais ideias coincidem também com minha percepção em relação à "normalidade" com que os alunos trabalharam tanto com sons quanto com ruídos, considerando ambos parte dos fenômenos musicais e de suas possibilidades expressivas junto a eles.

\subsection{CONSIDERAÇÕES DOS PROFESSORES SOBRE AS AULAS}

As entrevistas realizadas com os professores foram fundamentais para a percepção da compreensão do trabalho segundo a sua visão. Além das perguntas selecionadas previamente, algumas colocações referentes a questões diversas surgiram ao longo das entrevistas, como é previsto por Flick (2002) em entrevistas semiestruturadas, e já citado em momento anterior. A seguir, relato algumas das falas dos professores, e da mesma maneira como foi feito em relação às considerações dos alunos, associo essas falas com a literatura consultada e com minhas percepções pessoais.

Os professores foram solicitados, inicialmente, a relatarem livremente suas impressões sobre os jogos desenvolvidos nas instituições de ensino. Os quatro professores entrevistados relataram que gostaram, de maneira geral, dos jogos de improvisação oferecidos aos alunos. Essas respostas nem sempre estiveram em consonância com as minhas percepções durante a pesquisa de campo. Foi observado que, nem sempre em seus semblantes, durante a realização dos jogos, os professores demonstraram contentamento e aprovação. Considero que alguns dos “resultados" sonoros obtidos durante os jogos, ligados à exploração do instrumento e à possível produção de ruídos, possam ter sido associados pelos professores à "bagunça" ou "perda de 
tempo de aula". Porém, durante as aulas, os professores demonstraram extremo respeito ao trabalho e incentivaram os alunos a cumprirem as atividades.

Foram levantados pelos professores alguns pontos principais, como a integração entre os alunos e o desenvolvimento da criatividade. Podemos observar algumas dessas ideias nas falas:

Para a criatividade, o que achei superbom é esse início, onde você mostrou os sons, porque acho que abre um novo mundo para essas crianças que são formatadas, você sabe, de maneira mais acadêmica. Acho que não escutam, no Brasil, aqui no Brasil mais, muito música contemporânea. Então é uma abertura que achei superinteressante. Até que abrir esses diferentes jeitos de tocar. Então achei superinteressante...e para começar, porque já entramos num mundo de criatividade muito enorme (CEP, 2017, p. 4, professor A).

Achei superlegal. Porque é uma maneira de conhecer mais o outro, de, mais isso, no jogo da imagem. Tinha realmente um espírito de equipe, de time, que foi superinteressante. Acho que esses jogos, para criar um ambiente de classe, não sei, no início do ano, acho superinteressante (CEP, 2017, p. 5, professor A).

Pro grupo eu achei que funcionou bastante porque eles vão aprendendo a lidar, a conviver em grupo e a, sei lá, dividir opiniões e estratégias em grupo para desenvolver o trabalho que foi pedido, não é? Por exemplo, aquela que eles tinham que contar a história, colar as figuras, cada um inventava um pedacinho. Então eu acho que isso é importante pra incluir, não é, e deixar, e eles aprenderem essa convivência em sociedade, convivência em grupo, o trabalho em equipe. Acho que isso é muito importante, já que eles aprendem isso já cedo, no começo da formação (CEP, 2017, p. 11, professor B).

Além desses aspectos, e ainda avaliando as atividades, foi ressaltado por eles a necessidade de contextualização dos jogos em relação às atividades que os alunos já desenvolviam. Alguns professores acreditam que seria necessário maior aproximação entre os jogos realizados e o repertório tradicional, bem como a questões de ordem técnica. Esses professores acreditam que os jogos estavam focados apenas no repertório da música contemporânea que, geralmente, não é trabalhado com alunos iniciantes. Essa foi uma ideia trazida de diferentes maneiras e de maneira muito expressiva pelos professores, como se pode observar nas colocações referenciadas em seguida.

Eu achei tudo muito legal, mas eu fiquei pensando assim: como utilizar todo este conteúdo, através dos jogos, pra direcionar depois pra minha aula? Porque eu penso jogos e brincadeiras como um meio, não é, não é um fim, Eu fiquei curiosa com isso. Porque eu fiquei com isso na cabeça também porque os alunos perguntaram assim, depois eu conversei com eles, perguntei o que eles acharam, e claro, eles gostaram. Mas alguns me perguntaram, não todos, claro, alguns, uns dois ou três, me perguntaram aqui assim: "ah, professora, mas onde que a gente vai usar aqueles sons nas músicas que a gente toca aqui?" $\mathrm{E}$ eu disse: "é, realmente na maior parte das músicas que a gente toca a gente praticamente não usa nada daquilo" (CEP, 2017, p. 17, professor C). 
Depois, minha pergunta é: como usar isso depois em nosso jogo de instrumentistas? Você entende, fazer um vínculo entre essa aula de desenvolvimento da criatividade. Num momento $\mathrm{x}$, nós fizemos, mas agora, quando vou tocar Haydn em Dó, como vou poder usar essa liberdade, essas coisas que eu senti num momento $\mathrm{x}$ ? Você entende, é minha pergunta. Acho que já é superbom porque dá um momento de criatividade, de liberdade, sem nada, superbom, para o momento presente. Para usar na procura de criatividade numa frase musical, não sei como fazer o vínculo (CEP, 2017, p. 5 , professor A).

Então, eu fiquei curiosa, assim, se você tem no seu trabalho o direcionamento da aplicação do conteúdo. Porque o jogo é uma coisa, o jogo as crianças ali brincam, pra aprender aquele conteúdo, a gente dilui e apresenta pra eles e eles vão criar em cima, vão fazer um monte de outras coisas, mas eu queria saber assim: como que você pensa o direcionamento do conteúdo? (CEE, 2017, p. 17, professor C)

Que seja numa aula individual ou coletiva, mas que para crescer nossa criatividade, de verdade, para aumentar, não sei, acho que depois dessas duas aulas com você acho que não acrescentei realmente minha criatividade. Porque falta um vínculo para aplicar essas coisas dentro do nosso trabalho mais clássico (CEP, 2017, p. 5, professor A).

Mas aí eu acho que teria que ser adaptado só pro nível técnico, vamos dizer assim, o que cada uma já conhece no instrumento, mais por este lado, dessa forma (CEP, 2017, p. 10, professor B).

Eu achava inclusive interessante talvez adaptar pro conteúdo também que eles utilizem mais, a não ser que eu tenha assim também repertório com técnica expandida pra eles tocarem (CEP, 2017, p. 22, professor C).

Eu estava pensando, depois que passou as aulas, em tentar bolar alguma coisa que desse pra usar, ou as variações mais pra frente com, ou tocar o ritmo com con legno, chocolate quente, tocar a variação assim, ou tentar incluir algum ruído que elas aprenderam na peça. Eu estou pensando alguma coisa, tentando bolar alguma ideia, alguma estratégia pra elas usarem. Porque eu fico com receio, por exemplo, elas fizeram essa experiência, elas aprenderam muita coisa, aprenderam muitos sons novos e aí, por exemplo, na semana seguinte retomou o trabalho, e eles ficaram "nossa, mas pra quê que a gente fez aquilo tudo?" Não perder esse interesse, sabe, de manter elas com esse tipo de música, com esse tipo de som. Não deixar fugir do ambiente, da cabeça delas, mesmo tendo o foco de trabalhar a sonoridade diferente, a coisa mais, só que, eu queria incluir alguma coisinha assim pra elas mesmas tentarem usar tudo o que elas aprenderam, seria bacana (CEP, 2017, p. 15, professor B).

As colocações dos professores coincidem com algumas ideias trazidas por Kishimoto (2013), que dizem respeito às dúvidas que ainda persistem entre os educadores em relação à associação entre jogo e educação, entre elas, "se o jogo tem um fim em si mesmo ou se é um meio para alcançar objetivos" (KISHIMOTO, 2013, p. 13). Acredito que, em minha abordagem prévia com os professores, não ficou definida com total clareza qual seria a posição do trabalho, 
que está ligada às concepções de autores como Delalande (2001), Kater (2017) e Gainza (2007). Como autocrítica ao trabalho, considero que teria sido necessário abordar essas propostas junto aos professores em momento anterior à aplicação dos jogos.

De maneira espontânea, dois professores citaram ideias referentes à adequação técnica dos jogos. Um dos professores considerou que os jogos estavam um pouco acima da capacidade técnica dos estudantes, em oposição com a opinião de outro professor.

Eu gostei bastante, tinha algumas atividades que eu acho que eram apropriadas já para o nível que elas tinham. Por exemplo, as atividades que eu mais senti que elas tinham dificuldade eram com o arco, por não dominarem a forma de mão. Lembra que a gente até mandava fechar a mão para segurar para fazer algumas atividades? (CEP, 2017, p. 10, professor B).

Tudo estava para qualquer um que não tivesse tocado violoncelo antes, estava ainda acessível, pizzicato com corda solta, as coisas com o arco elas deram conta bem de fazer, acho que isso é muito estimulante pra eles, foi muito estimulante. Todo mundo deu conta de fazer tudo e consegue criar a partir da sua proposta, basicamente. Acho isso mais interessante, você tem um objetivo, você cumpre e você pode colocar alguma coisa que é seu, que é artístico (CEP, 2017 , p. 25, professor D).

Essas diferentes opiniões apresentadas, sob o meu ponto de vista, estão relacionadas com as diferentes propostas educacionais desenvolvidas pelos professores e com a visão de ensino e de música que os professores trazem consigo. Segundo Carlos Kater (2017), os conceitos, funções e ideias do "professor de música" e do "educador musical ou músicoeducador" são diferentes entre si e se consolidam em visões dentro e fora da academia (KATER, 2017, p. 160). Para o autor, suas atuações também se distinguem, bem como as metas que visam. Kater (2017) contextualiza que o "professor de música" estaria mais preocupado com a transmissão de conteúdos e a formação musical, enquanto "para o educador musical a concepção é diferente, e abarca o que falei antes... vem ao palco das atenções a pessoa do aluno, seu desenvolvimento pessoal e musical, seu protagonismo" (KATER, 2017, p. 160). Sob minha perspectiva, concordo com Kater, e considero que as diferentes visões apresentadas se conectam com essas ideias, sendo que um dos professores estava mais preocupado com as questões técnicas, como a forma da mão do arco, enquanto o outro, mais com as questões pessoais, como o estímulo e a expressão artística.

Considero que nenhuma das visões apresentadas é "certa" ou "errada" e considero extremamente importante explicitá-las aqui. Elas apontam para a necessidade de melhor contextualizar algumas das práticas em abordagens futuras. Acredito que as ideias apresentadas pela pesquisa consideravam a possibilidade de o professor de instrumento trabalhar também como educador musical, conforme os conceitos trazidos por Kater (2017), e essa abordagem 
ainda está longe da realidade da maioria dos professores de instrumento, podendo, eventualmente, gerar insegurança e estranhamento. Sendo assim, é necessário situar a proposta dentro de uma visão ampla a respeito das ideias de música e de educação musical, para que possa ser compreendida e contextualizada.

Com o intuito de conhecer a possível aproximação dos professores com o repertório da música contemporânea e verificar se essa aproximação exerceria alguma influência em suas considerações sobre os jogos, foi perguntado a eles se costumavam interpretar música do repertório atual. Dos quatro professores entrevistados, dois não tem o costume de executar, eles próprios como intérpretes, música do repertório atual. Os outros dois tiverem acesso a esse repertório durante o curso de graduação e permanecem nele interessados, em maior ou menor grau. Um deles continua executando o repertório de música contemporânea, mesmo após o término da sua formação universitária.

Não houve coincidência total das respostas dadas pelos professores com as percepções relatadas por eles a respeito dos jogos. Um professor, por exemplo, que relatou que gostava de música contemporânea, mostrou-se distante das propostas dos jogos, enquanto por parte de outro professor, que não costumava executar música contemporânea, houve grande adesão às atividades, sendo apontado que tais práticas "abrem a cabeça" dos alunos para esse tipo de repertório, considerado importante por ele.

\footnotetext{
Mas, no geral, não escuto muito música contemporânea, assim, música contemporânea no sentido de mais ruídos, efeitos, esse tipo. Então, não sou muito entendedor desse tipo de música, não é meu foco. Até já tentei pesquisar um pouco mais, saber um pouco mais, pra sabe, "ah, não gosto, não vou ouvir, não vou fazer”. E é importante também pra música, pra evolução da música, mas eu não entendo muito bem, não ouço muito. Mas, por exemplo, com todas as atividades que você fez, os efeitos, também, já abre a cabeça dos alunos também pra entender que é uma forma de música, é uma forma de som e que eles vão usar isso um dia (CEP, 2017, p. 15, professor B).
}

Foi questionado aos professores quais abordagens eles costumavam utilizar para trabalhar conteúdos relativos à expressividade e à criatividade junto aos alunos iniciantes. Essa questão foi formulada com a intenção de verificar se os professores utilizavam estratégias semelhantes às utilizadas durante os jogos de improvisação. Todos os professores entrevistados relataram que estão em constante mudança, dependendo de variáveis apresentadas por cada turma envolvida em determinado trabalho. Podemos observar algumas colocações feitas em relação à essa pergunta nas falas seguintes.

Eu uso muito o canto, muito, muito. Eu acho que o canto ajuda bastante. Sempre eu falo, cada nota que foi tocada deve ser cantada antes. Sou super do canto interior. Falo: você não pode começar sem saber o que você quer, tem 
que ter um objetivo. E cantando, para nuanças, para expressividade, para tudo isso, é o melhor, acho que é a melhor coisa. Acho que quando você canta, você vê a diferença, quando você toca você sabe o que fazer para ter o resultado que você quer (CEP, 2017, p. 8, professor A).

$\mathrm{Eu}$, sinceramente, confesso para você que eu faço sim, mas eu procuro sempre utilizar material que eles já estão utilizando em sala de aula, coisas que a gente está fazendo. Eu, por exemplo, eu gosto de fazer exercícios de composição com eles. Eu pego, preparo um papelzinho pra eles com tantos compassos, por mais que eles estejam ainda no primeiro semestre, não saibam direito ainda $o$ que é compasso, eles já sabem assim que é uma contagem de quatro em quatro. Então, eles já entendem a ideia principal, e eu peço para eles escreverem o ritmo com a notinha embaixo. Eles têm que criar alguma coisa, tem que ter uma pausa no meio, tem que criar uma frase, sabe? (CEP, 2017, p. 21, professor C).

Eu acho que me parece agora o jeito mais eficiente de se apropriar do material, dessa coisa de possibilidades de dinâmica, de ritmo, é quando você pega e mexe, né, manipula. Porque só a aula expositiva não dá conta de ver se o pessoal entendeu mesmo, não dá tempo deles experimentarem, aí quando vai para o repertório (CEP, 2017, p. 27, professor D).

Quando eles estão aprendendo alguma peça, eu uso um pouco pizzicato até eles entenderem as notas e aí eu vou fazendo isso em todas as peças. Quando eles já têm segurança em alguma peça, sei lá, variação $A$, aí eu uso a variação A para trabalhar outras coisas, o relaxamento, por exemplo. Às vezes, está fazendo o ritmo certinho, mas está com o braço todo duro. Quando eles têm segurança já na peça, aí vou trabalhando outras coisas. A gente toca novamente e aí eu falo "ah, vamos tentar tocar agora balançando o corpo, transferindo o peso do pé um pro outro, balançando a cabeça, e tal", este tipo de atividade (CEP, 2017, p. 13, professor B).

Porém, analisando os depoimentos apresentados, percebo que nenhum dos professores possui total clareza dos tipos de abordagens que utilizam e quais poderiam ser utilizadas para esse fim, pois foram citadas questões relacionadas a processos de compreensão intelectual. Sendo assim, acredito que ainda exista um caminho a ser trilhado para que elementos como a criatividade e a expressividade sejam melhor desenvolvidos pelos professores e para que sejam elaboradas estratégias direcionadas ao trabalho de propostas ligadas a esses aspectos.

Também foi perguntado aos professores quais estratégias eles utilizavam para trabalhar a iniciação ao violoncelo. Tal pergunta tinha como intuito pesquisar se as abordagens utilizadas por eles eram similares às abordagens utilizadas por seus professores, enquanto esses eram estudantes. De maneira geral, um deles utiliza o Método Suzuki para realizar a iniciação ao violoncelo. Outro professor utiliza o método All for strings, mesclando-o com ideias e estratégias selecionadas por ele, advindas de outras abordagens. Outro, utiliza a metodologia tradicional e mais outro, procura abordar o ensino de maneira a introduzir elementos de criação 
para a compreensão dos parâmetros musicais. Alguns excertos de suas falas exemplificam essas concepções.

Eu uso o Suzuki. Na verdade, o Suzuki eu conheci recentemente também, vai fazer dois anos. A minha primeira turma foi essa turma que saiu agora. Então, eu estou usando algumas estratégias que eu conheci no curso do David (Evenchick), que você conhece (CEP, 2017, p. 13, professor B).

Eu procuro sempre estar experimentando várias coisas, eu nunca deixo de uma maneira só, claro, como eu já tenho um tempinho de experiência, por experiência eu já fui vendo coisas que acabam tendo uma abrangência bastante grande pra funcionar para a maioria dos alunos, então, algumas formulinhas eu sempre uso, praticamente as mesmas, mas eu sempre gosto de mudar estratégias também, vai por um caminho que faz primeiro isso, depois aquilo, eu não tenho uma cartilha, não (CEP, 2017, p. 19, professor C).

Pelas respostas fornecidas por esses professores e relacionando-as com a maneira como eles mesmos iniciaram no violoncelo, pode-se perceber que alguns seguem os mesmos padrões de ensino que receberam, baseados nas chamadas "abordagens tradicionais", enquanto outros seguem abordagens distintas, consideradas mais atuais. Porém, entre as abordagens citadas, como o Método Suzuki e o All for strings, percebe-se que essas são fundamentadas também em algumas características que advêm das "abordagens tradicionais", como por exemplo, propor o mesmo padrão de ensino e a mesma sequência de repertório musical para diferentes turmas e perfis de alunos, desconsiderando a individualidade de cada um.

Também foi perguntado aos professores se eles acreditavam que as atividades foram benéficas aos alunos, acrescentando conhecimento, experiência, vivências, etc. Os quatro professores entrevistados relataram que os alunos envolvidos nas atividades gostaram das aulas e encontros oferecidos. Foram citados elementos como relaxamento, espontaneidade, e aderência às ideias relacionadas à exploração sonora.

Elas gostaram, como eu falei, elas fazem até hoje, os glissandos, os sons harmônicos, o con legno. Vira e mexe elas estão fazendo, quando elas não estão muito seguras elas vão lá e fecham a mão pra fazer. Uma aluna mesmo, que ainda não desenvolveu ainda a forma da mão do arco, quando eu peço pra fazer o chocolate quente ela fecha a mão e tenta fazer. E quando eu estou explicando alguma coisa pra outra colega ela tá lá fazendo, bate assim com o arco, con legno, ela faz (CEP, 2017, p. 15, professor B).

Ele gostou muito. Ele é super interessado para tudo isso. Acho que ele gostou muito porque ele tem muita tensão. Acho que no momento foi super bom porque ele aprendeu a relaxar, aprendeu a abrir. $\mathrm{Na}$ aula não vou te falar que mudou as coisas, seria uma mentira, é um processo. Então acho que seria super interessante ter isso toda a semana, num semestre (CEP, 2017, p. 9, professor A).

Mas tem algumas atividades que elas gostaram tanto que elas fazem até hoje. Às vezes eu estou explicando alguma coisa pra uma e elas ainda estão fazendo, 
os harmônicos, por exemplo, vira e mexe eu vejo. Elas nem sabem segurar o arco direito, mas tão lá passando o arco na corda e fazendo os harmônicos, ou con legno também (CEP, 2017, p. 10, professor B).

Foi perguntado também aos professores se planejavam continuar utilizando algumas das abordagens propostas pelos jogos de improvisação em suas atividades pedagógicas. Os quatro professores, de maneira diversa, relataram que vão seguir utilizando algumas das estratégias desenvolvidas. Algumas considerações são trazidas nas falas:

Então, ao invés de já começar explicando as notas ou colocar alguma coisinha pra eles lerem, eu acho que eu vou usar alguma coisa assim, das figuras. Achei interessante essa atividade. Eu acho que eu vou fazer isso, gostei bastante disso. Eles imaginarem uma história que tem, uma figura quer dizer tal coisa, pra eles reproduzirem no instrumento. Acho que vai ficar fácil deles entenderem. Assim, desenvolve a criatividade, elas aprendem uma coisa, essa questão da leitura. Eu adorei essa atividade, vai funcionar muito bem (CEP, 2017, p. 15, professor B)

Eu creio que sim, eu creio que sim, às vezes eu acho que eu posso não lembrar de tantos detalhes, mas com certeza os alunos vão me lembrar com isso (CEP, 2017, p. 22, professor C)

Um professor relatou que já iniciou a utilização de algumas das estratégias dos jogos de improvisação, inclusive apresentando-as em audição pública, comentando que essa apresentação teve boa aceitação do público ouvinte.

A gente tocou primeiro, aí eu expliquei a história e tocamos de novo. Aí todo mundo deu risada depois, porque a história é meio tragicômica e gostaram. Estava todo mundo meio surpreso, parecia (CEP, 2017, p. 26, professor D).

Por meio das considerações apresentadas, acredito que os jogos oferecidos às instituições abordaram aspectos que, na maioria das estratégias relacionadas ao ensino e à aprendizagem do violoncelo, ainda não são contemplados. No meu entender, a principal dificuldade apontada pelos professores, que diz respeito à contextualização dos jogos dentro de uma esfera "tradicional", musical e técnica, está ligada às concepções formais que são transmitidas nas universidades e centros de ensino a respeito das ideias de música e de ensino musical. Considero que a maioria dos professores entrevistados, por seu perfil, por suas respostas às entrevistas e por suas reações durante a pesquisa de campo, possui uma concepção ligada a essas ideias e práticas de ensino.

Sob meu ponto de vista, considero que, em paralelo à contextualização da proposta dentro de um modelo de ensino "tradicional", seja necessária uma reavaliação das ideias de música e de ensino musical, para que propostas semelhantes, relacionadas à criação, possam ser melhor compreendidas. Acredito que apenas dessa forma será viabilizada sua adoção. 
Alguns educadores e pesquisadores já sinalizam e orientam para a necessidade de que o professor de música seja um profissional habilitado em outras qualidades, que não apenas a transmissão de conteúdos musicais. Carlos Kater (2017), por exemplo, aponta para o fato de que o professor de música, que trabalha com processos de criação, precisa ser um profissional preparado e disposto a lidar com conteúdos internos que são despertados por essas atividades.

De fato, necessitamos de um profissional preparado, que tenha espectro de atuação mais amplo e - enquanto educador musical ou músico-educador - seja também uma pessoa melhor cuidada, isto é, alguém que compreenda a importância de se conhecer melhor e experimente um trabalho sobre si, sobre a sua própria pessoa, como insisto. É sabido que todo processo de criação musical implica em descoberta, nomeação, expressão e novas formulações; compete a esse profissional instaurar o espaço no qual todos os participantes poderão observar um som nascer pelas mãos e desejo de alguém, ser variado, acrescentado ou transformado pela imaginação de outro e assim, paulatinamente, de modulação em modulação, escutar o surgimento de cada música, com a vida particular que cada música tem. Mas para escutar um som vibrando, ouvir uma música soando e perceber a vida se movendo dessa forma, é necessário parar e silenciar um pouco internamente. Fora disso não há meio possível de acolher as coisas e as pessoas como são. E cabe a esse profissional propiciar que as crianças também penetrem neste espaço diferenciado - situado um "palmo acima do chão" -, onde as diferenças com os "outros" não atrapalham tanto, nem criam de fato maiores problemas, mas ao contrário... "aquilo" que somos, com nossas particularidades e diferenças, se torna justamente "aquilo" que enriquece e dinamiza a vida de todos (KATER, 2017, p. 158).

No mesmo texto, Kater (2017) propõe uma crítica ao discurso que se propaga de maneira consistente em escolas e centros educacionais de música, mas que muitas vezes está distante da realidade do trabalho oferecido por tais instituições e pelos profissionais que atuam em seus projetos.

Falamos com frequência em respeito, tolerância, criatividade, qualidade de vida, cultivo da sensibilidade, desenvolvimento pessoal, autonomia, diversidade e tantas outras belas palavras mais... Entretanto, muito pouco temos visto quanto à prática efetiva desses conceitos, dentro das salas de aula e fora delas também! O discurso sobre a música e sobre a vida parece satisfazer as demandas imediatas da realidade, bem como a imagem confortante e asseguradora que tantas instituições e educadores ainda têm de si (KATER, 2017, p. 159).

Considero que a crítica de Kater (2017) se aplica também ao que foi pesquisado junto às instituições, durante esse trabalho. Apesar de todas elas proporem práticas criativas em suas maneiras de ensino, nem sempre está bem claro para os educadores que atuam nessas instituições como inserir essas práticas dentro das atividades de suas aulas. 


\section{CONSIDERAÇÕES FINAIS}

Esse trabalho teve como objetivo investigar a implementação de jogos de improvisação na iniciação coletiva ao violoncelo, com o intuito de proporcionar a aproximação dos estudantes com as poéticas da música contemporânea. Para tanto, foi realizada uma revisão bibliográfica sobre improvisação e sua aplicação pedagógica, bem como ideias e conceitos de jogo e sua relação com a arte. Também foram investigadas algumas abordagens de utilização de poéticas da música contemporânea para a iniciação instrumental e as concepções das práticas de ensino instrumental coletivo. Além da pesquisa bibliográfica, foi desenvolvida uma pesquisa-ação em três contextos educacionais. localizados no estado de São Paulo, o Instituto Baccarelli, o Projeto Guri-Polo de Indaiatuba e o Instituto Fukuda.

A pesquisa de campo ocorreu em momentos distintos em cada uma das instituições de ensino, durante o segundo semestre de 2017. No Instituto Baccarelli essa pesquisa se deu num modelo de dez encontros, enquanto no Projeto Guri-Polo de Indaiatuba e no Instituto Fukuda ocorreu de forma concentrada, em dois encontros. Como instrumentos de coleta de dados, além da observação participante e das anotações no Diário de Campo, foram realizadas algumas gravações em vídeo, que serviram como apoio para as anotações, foi aplicado um questionário com dez questões junto aos alunos, foram realizadas entrevistas com os professores participantes e foram coletadas anotações e impressões dos alunos sobre cada jogo realizado, por meio de depoimentos por escrito e desenhos.

$\mathrm{Na}$ intervenção, foram aplicados jogos de improvisação na iniciação coletiva ao violoncelo. Tais jogos, em sua maioria, já haviam sido testados em outros grupos instrumentais. Outros foram criados especialmente para o desenvolvimento desse trabalho. Os jogos escolhidos para a proposta tinham como objetivos desenvolver a liberdade de relacionamento com o instrumento em vários planos, proporcionar conhecimento dos recursos sonoros do violoncelo, trabalhar a atenção, a concentração, a criatividade, a liderança e autonomia, o espírito de equipe, a atenção na escuta, a autoestima e o autoconhecimento, bem como a aproximação dos estudantes com as poéticas da música contemporânea.

Sob a perspectiva dos estudantes e dos professores participantes, os jogos alcançaram os objetivos inicialmente propostos. Os estudantes enfatizaram as características lúdicas presentes nas atividades, bem como seu caráter musical, mostrando-se conectados com algumas concepções trazidas pelas poéticas musicais apresentadas. Também demonstraram, através de seu posicionamento frente às atividades, pronta autonomia criativa, o que foi confirmado através de seus depoimentos e análises. Os estudantes confirmaram o estabelecimento de um 
vínculo construtivo às novas propostas de interação com o instrumento, trazidas pelas atividades da pesquisa. Através de seus depoimentos e considerações, os estudantes enfatizaram que as abordagens trazidas pela pesquisa possibilitaram a compreensão de estéticas ligadas ao repertório da música contemporânea.

Os professores destacaram principalmente as qualidades relacionadas à integração entre os alunos, possibilitadas pelos jogos, além de considerarem que os jogos trouxeram novas formas de escuta e novas maneiras de abordar o instrumento, bem como se mostraram uma estratégia eficiente para a iniciação coletiva ao violoncelo. Foi considerada pela maioria dos professores a possibilidade da utilização de algumas das estratégias apresentadas pelos jogos em sua maneira de ensino. Em contrapartida, foi apontada por alguns deles, a necessidade de melhor contextualização dos jogos dentro de um modelo ligado às estéticas musicais tradicionais, pois foi levantado por eles que as propostas relacionadas à música contemporânea, trazidas pelos jogos de improvisação, não eram utilizadas habitualmente por eles dentro das instituições. Segundo tais professores, tal abordagem pode ter causado dúvidas nos alunos em relação à aplicabilidade de alguns elementos, como por exemplo, o uso das técnicas estendidas. Os professores levantaram a ideia de que os jogos poderiam ter abordado conteúdos relativos à técnica e ao repertório tradicionais, que se situam dentro do universo onde comumente as aulas de instrumento nas instituições contempladas pela pesquisa estão inseridas.

Através dos resultados obtidos, acredito que a elaboração, execução e análise desse trabalho possam ter trazido algumas contribuições para as áreas envolvidas nesse processo. Acredito que para as instituições de ensino que participaram das atividades, a pesquisa possa ter colaborado para a idealização de novas possibilidades de trabalho direcionadas à iniciação musical ao violoncelo. As atividades realizadas durante o trabalho se mostraram estratégias distintas das tradicionalmente utilizadas pelas instituições, mas em consonância com suas premissas pedagógicas. Da mesma forma, creio que a participação dos professores nas atividades possa ter agregado novas ideias e perspectivas individuais de trabalho.

Acredito também que a aproximação gerada entre as instituições de ensino e a pesquisa contribui para a valorização do trabalho realizado por cada uma delas, pois ressalta a importância social e artística de suas atividades. No meu entender, essa aproximação contribui para a diminuição da distância entre as áreas acadêmicas e a prática pedagógica, incentivando a incorporação dos resultados das pesquisas em tal prática. Acredito que essa aproximação seja também importante para a área da educação musical. Observar a dinâmica de trabalho das instituições e ouvir as falas dos seus professores a respeito da pesquisa realizada, bem como 
algumas de suas ideias e inquietações sobre a educação musical, contribuem para a motivação da elaboração de novas pesquisas que promovam maior integração entre as áreas.

No âmbito desse trabalho, em particular, destaco a constatação da carência de material pedagógico, principalmente de origem nacional, direcionada a alunos iniciantes ao violoncelo e a necessidade de que tais materiais possam ser elaborados por educadores musicais, em conjunto com os professores de instrumentos. Também acredito que essa pesquisa reforça a necessidade da adoção de estratégias de ensino de instrumento ligadas a práticas de criação e a possibilidade de que tais estratégias possam ser incorporadas nos programas de ensino instrumental, em coexistência com demais abordagens.

Creio que a pesquisa realizada possa contribuir para alertar os educadores para necessidade da revisão do papel do professor de instrumento musical, que, em consonância com seus resultados, aponta para a incorporação dos papéis de educador como mediador da aprendizagem. Observo que essa discussão se agrega a ideias que vem sendo debatidas em diferentes âmbitos das áreas de educação musical e de performance, onde vem sendo trazidas diferentes concepções sobre a possível incorporação de disciplinas com viés pedagógico nos cursos de Bacharelado em Música, o que possibilitaria uma formação mais completa de futuros professores de instrumento musical. Sendo assim, acredito que alguns resultados da pesquisa possam contribuir para essa discussão, principalmente entre os professores de instrumento.

Sob outro aspecto, acredito que a pesquisa possa trazer algumas possibilidades de incorporação do repertório e das estéticas da música atual na iniciação instrumental. O trabalho realizado aponta para a ideia da viabilidade da aplicação da música da atualidade nessa formação, contribuindo para a desmistificação da concepção de que as poéticas da música contemporânea possuem lugar apenas entre instrumentistas de nível avançado de execução. Essa perspectiva permeia tanto as áreas da educação musical quanto da performance, que caminham lado a lado nos processos de formação instrumental. Acredito que a pesquisa contribui para chamar a atenção para a importância da aproximação dos estudantes com as poéticas da música contemporânea e reforça a necessidade da elaboração de propostas e repertório de música atual de cunho didático por professores, educadores e compositores, acrescentando a produção de apostila direcionada a professores de violoncelo, em que estão transcritos os modelos de improvisação utilizados na pesquisa de campo, oferecendo algumas ideias e subsídios para a elaboração de abordagens futuras.

Tendo em vista os resultados apontados, esse trabalho sinaliza para a necessidade de que seja oportunizado aos alunos de instrumento, o que foi chamado durante esse texto, de “empoderamento criativo". Através dos resultados da pesquisa foi possível detectar, por 
exemplo, que algumas dessas abordagens, como por exemplo, a utilização da mimese enquanto estratégia pedagógica, são capazes de estabelecer relações sutis com os conteúdos psicológicos e do entorno, possibilitando que os estudantes incorporem em seu leque, novas possibilidades expressivas, capazes de representar seus pensamentos e sentimentos através das atividades musicais.

Sob outro ponto de vista, a pesquisa sinaliza para uma maior diversificação de estratégias possíveis de serem adotadas na iniciação coletiva ao violoncelo, chamando atenção para a importância do ensino coletivo e para as habilidades e valores que podem ser desenvolvidos com sua aplicação. Os jogos de improvisação coletiva, ao trazerem situações semelhantes às da vida cotidiana, podem atuar como importante veículo para a observação e construção de vivências e possibilidades de interação social, além de constituírem-se em processos de troca de saberes entre os indivíduos envolvidos. Segundo os resultados da pesquisa, os jogos desenvolvidos possibilitaram que os estudantes compartilhassem ideias e valores sociais.

O trabalho realizado aponta para a possibilidade de continuidade da pesquisa sobre o uso de jogos de improvisação, envolvendo outros estágios de aprendizagem ao violoncelo, como por exemplo, os estágios intermediários e avançados. Também vislumbra possibilidades de aplicação dos jogos de improvisação coletiva para os demais instrumentos de cordas friccionadas, que apresentam características semelhantes ao violoncelo. Sob outro ponto de vista, sinaliza para a necessidade de investigação mais específica a respeito das estratégias de ensino musical utilizadas pelos professores de violoncelo na iniciação ao instrumento, a fim de que se possa compreender com mais propriedade como é feita essa iniciação.

Como autocrítica ao trabalho realizado, considero importante destacar algumas dificuldades apresentadas, oferecendo a possibilidade de que pesquisas semelhantes possam ser realizadas no intuito de sanar tais dificuldades, aprofundando, assim, seus resultados. Uma dessas dificuldades, foi relativa à necessidade de se estabelecer um vínculo efetivo entre professor e alunos, e ao curto espaço de tempo disponível para que esse vínculo se configurasse. Sendo assim, considero que, em semelhantes trabalhos de pesquisa, ao serem abordados em contextos onde este vínculo se estabelecesse mais fortemente, poderiam apresentar novos resultados embasados em características importantes presentes nessa relação, como a confiança no professor e no trabalho a ser desenvolvido por ele. Considero também que, em um novo contexto de pesquisa, os jogos de improvisação poderiam ser apresentados de maneira a intercalarem-se com conteúdos do ensino formal do instrumento, de forma que fossem compreendidos como parte integrante desses conteúdos. 
Cabe destacar que, assim como foi notado em meu Diário de Campo, o trabalho de pesquisa empírica, muitas vezes, esteve subordinado a questões relativas ao tempo disponível para sua aplicação, o que, muitas vezes, impossibilitou que as atividades pudessem ser reproduzidas mais de uma vez, a fim de que fossem incorporados novos elementos de complexidade. Sendo assim, considero como sugestão a novos trabalhos, que possa ser destinado mais tempo e também diferentes abordagens para cada atividade, onde sejam incorporados diferentes níveis de complexidade às atividades.

Levando em consideração algumas observações surgidas durante o trabalho, aponto como sugestão a novas pesquisas, a aplicação dos jogos levando em consideração a determinação de faixas etárias específicas. Durante a aplicação desse trabalho não foram especificadas as faixas etárias onde ocorreria a pesquisa de campo, sendo que essa seleção ocorreu levando-se em consideração o nível de aprendizagem instrumental, independente da faixa etária. Dessa maneira, acredito ser importante para a continuidade do trabalho a aplicação dos jogos segundo determinadas faixas etárias, a fim de se verificar possíveis diferenças ou semelhanças entre os resultados. Da mesma forma, não foram estabelecidas investigações visando características geográficas e socioeconômicas relacionadas aos campos empíricos. Acredito que em pesquisas futuras possam ser investigadas com mais propriedade a influência de variáveis ligadas à geografia e a determinantes socioeconômicas.

Além dessas questões, acredito que algumas lacunas observadas durante a análise do material pesquisado possam ser levadas em consideração em abordagens futuras. Acredito que seja importante a gravação de maior parte do processo, a fim de que se possa incorporar mais elementos às anotações a serem realizadas em Diários de Campo, assim como se possa oferecer aos alunos a possibilidade de contemplar, em conjunto, algumas dessas gravações, a fim de que essas sejam observadas e analisadas por eles, sendo incluídas essas observações nas análises dos resultados. De igual maneira, acredito ser importante também abrir espaço para que os alunos possam verbalizar oralmente suas considerações sobre os jogos, compartilhando com seus colegas suas observações, e que essas observações também possam ser incorporadas à análise dos resultados, bem como seja oportunizado, que, a partir dessas observações, os alunos possam criar jogos de autoria própria, a serem testados também durante a pesquisa. Em consonância com essas ideias apresentadas, acredito que seja importante que o professor compartilhe de forma mais efetiva com os alunos gravações em áudio ou vídeo que estejam ligadas a algumas poéticas musicais, semelhantes às propostas de criação que os jogos oferecem, a fim de que os jogos sejam melhor contextualizados dentro dessas concepções musicais. 
Considero importante também, que em pesquisas futuras, exista a criação de um espaço maior de trocas entre os pesquisadores e os professores que, por ventura, se envolverão na pesquisa. Acredito que seja necessário abordar junto aos professores, e não apenas junto às instituições, qual a proposta de improvisação e de música que se pretende investigar, para que assim, se esclareça em que sentido estão sendo utilizados os conteúdos relacionados a essas atividades, evitando o possível estranhamento em relação a tais atividades. Sendo assim, destaco que essa aproximação com os professores poderia também acrescentar um elemento colaborativo ao trabalho, onde os professores poderiam propor, ou mesmo criar em conjunto com os pesquisadores e com os alunos, atividades que se adequariam às suas demandas pedagógicas.

Como sugestão a novas pesquisas, considero também que se possa investigar com mais propriedade o universo dos professores de instrumento. Conforme foi constatado nas entrevistas realizadas com os professores, foi possível detectar a necessidade desses professores em compartilhar suas posições em relação à educação instrumental, suas inquietações, carências e demandas, observando-se que nem sempre é claro aos professores suas atribuições enquanto educadores musicais. Sendo assim, acredito que esse ainda é um campo que merece mais atenção, para que se possam mapear essas demandas, a fim de proporcionar, estratégias conjuntas entre pesquisadores e professores, que contemplem algumas dessas necessidades, bem como sejam percebidas pelos professores, e consequentemente valorizadas, as suas funções como músico-educadores, proporcionando a esses profissionais a autonomia dessas funções e seu reconhecimento enquanto classe.

Ao concluir essas considerações acredito que, assim como destacado anteriormente, a pesquisa realizada aponta para diferentes caminhos, revisões e perspectivas de continuidade. Ressalvo que os jogos de improvisação trazidos aqui não se constituem em modelos fixos e impassíveis de transformação. Meu desejo pessoal, enquanto pesquisadora, é que os jogos apresentados sirvam apenas como referência para novas possibilidades para nossa atuação enquanto professores de instrumento, que contribuam para a revisão do nosso papel enquanto educadores musicais e que nos capacitem a proporcionar e fomentar formas de pensamento e de ação em nossos alunos, baseadas em princípios de igualdade, coletividade e senso humanitário. 


\section{REFERÊNCIAS}

ABERASTURY, Arminda. A criança e seus jogos. São Paulo: Ed Vozes, 1972.

ALBINO, César Coelho. A importância da improvisação musical no desenvolvimento do intérprete. 2009. 220 f. Dissertação (Mestrado em Música) - Instituto de Artes, Universidade Estadual Paulista "Júlio de Mesquita Filho", São Paulo, 2009.

ALONSO, Chefa. Improvisación libre: la composición en movimiento. Baiona: Editorial Dos acordes S. L., 2007.

AMIGOS DO GURI. Quem Somos. Associação Amigos do Projeto Guri: organização social de cultura. São Paulo, 2014. Disponível em: $\leq$ http://www.projetoguri.org.br/quem-somos/ $>$. Acesso em 03 de novembro de 2018.

ANGELO, Bruno. Negrinho do Pastoreio. Porto Alegre; Acervo do compositor, 2013, 1 partitura $[4$ p.]. Violoncelo.

ARAÚJO, Gessé Almeida. Poética(s): a criação artística em fricção com o(s) tempo(s) presente(s). Cena, Porto Alegre, n. 23, p. 111-120, 2017.

ARISTÓTELES. Poética. In: A poética clássica. São Paulo: Cultrix, 1997.

BAILEY, Derek. Improvisation: its nature and practise in music. Boston: Da Capo Press, 1993.

BARBOZA, Ana Mae. John Dewey e o ensino da arte no Brasil. $3^{\text {a }}$ ed. São Paulo: Cortez, 2001.

BARTÓK, Béla. 44 duos para dois violinos. Viena: Universal Edition, 1992, 1 partitura [53 p]. Violino.

. Mikrokosmos. Londres: Chester Music, 2016, 1 partitura [271p.]. Piano.

For children. UK : Boosey \& Hawkes, 2015-2016, 1 partitura [48p.]. Piano.

BEDFORD, David; BRETT, Alan; DENNIS, Brian; SELF, Georges, SCHAFER, Murray; RANDS, Bernard; FLUSSER, Elisabeth; KRATOCWILL, Heinz. Jeunes musiques: Collection de partitions de musique contemporaine pour enfants et musiciens débutants. Universal Edition, 1 partitura [xxp.]. Vários instrumentos.

BOGDAN, Robert; BIKLEN, Sara. Investigação qualitativa em educação: uma introdução à teoria e aos métodos. Porto: Porto Editora Ltda, 1994.

BONDÍA, Jorge Larrosa. Notas sobre a experiência e o saber da experiência. Revista Brasileira de Educação. Campinas, n.19, p- 20-28, 2002.

BONIS, Maurício de. Parciais em pares. São Paulo: Urbana, 2012, 1 partitura [2 p.]. Violoncelo. 
BOTA, João Victor. Dimensões. São Paulo: Urbana, 2012, 1 partitura [1 p.]. Violoncelo.

BRASIL. Ministério da Educação e do desporto- Secretaria de educação fundamental. Parâmetros Curriculares Nacionais - Arte. Brasília, 2000.

BRIETZKE, Marta; VILLENA, Marcelo. Integração de conhecimentos de professor de violoncelo e compositor para a elaboração de repertórios didáticos. In: IV Mostra de Violoncelos de Natal, Natal, Anais..., 2014.

BRITO, Maria Teresa Alencar de. Koellreutter educador: o humano como objetivo da educação musical. $2^{\mathrm{a}}$. ed. São Paulo: Peirópolis, 2011.

. Música na educação infantil: propostas para a formação integral das crianças. São Paulo: Editora Peirópolis, 2003.

BROUGÈRE, Gilles. Jogo e educação. Porto Alegre: Artes Médicas, 1998.

CAMARGO, Elisabeth Bueno de. O pensamento musical e a prática docente: as demandas da contemporaneidade no ensino de música. 2007. $127 \mathrm{f}$. Tese (Doutorado em Educação) Faculdade de Educação, Universidade de São Paulo, São Paulo, 2007.

CARVALHO, Maria Salete de. Iniciação ao violoncelo: Análise de três métodos e proposta de sua suplementação com repertório do folclore brasileiro. 2010. 131 f. Dissertação (Mestrado em Música) - Centro de Letras e Artes- Universidade Federal do estado do Rio de Janeiro, Rio de Janeiro, 2010.

CASTRO, Guilherme Peluci de. Problemas de performance em improvisação dirigida: um estudo comparativo dos sistemas soundpainting e conduction. 2015. 192 f. Dissertação (Mestrado em Música) - Escola de Música, Universidade Federal de Minas Gerais, Belo Horizonte, 2015.

CERVO, Cervo. Dança Negra. São Paulo: Urbana, 2012, 1 partitura [1 p.]. Violoncelo.

CHATEAU, Jean. O jogo e a criança. São Paulo: Summus, 1987.

COSTA, Rogério Luiz. Desdobramentos. São Paulo: Urbana, 2012, 1 partitura [2 p.]. Violoncelo

Música errante: o jogo da improvisação livre. São Paulo: Perspectiva: Fapesp, 2016.

- Processos de consistência e contextos na improvisação livre: aproximações preliminares. ORFEU, Florianópolis, v.2, n.1, 2017.

Tranversalidades: música e política. Série Diálogos com o Som. Belo Horizonte, v. 4, p $67-83,2017$.

CRUVINEL, Flavia Maria. O ensino coletivo de instrumentos musicais na educação básica: compromisso com a escola a partir de propostas significativas de ensino musical. In: VIII Encontro Regional Centro-Oeste da Associação Brasileira de Educação Musical, $1^{\circ}$ Simpósio 
sobre o Ensino e a Aprendizagem da Música Popular e III Encontro Nacional de Ensino Coletivo de Instrumento Musical, Brasília, Anais..., 2008.

DANTAS, Taís. O ensino coletivo de instrumentos de cordas: desenvolvimento musical, diversidade e planejamento. In: CHAGAS, Antônio; ALMEIDA, Robson (orgs.). Educação Musical e Práticas Instrumentais. Juazeiro do Norte: UFCA, 2016.

DELALANDE, François. La música es un juego de niños. Buenos Aires: Ricordi Americana, 2001.

DELEUZE, Gilles. Lógica do Sentido. 4a ed. São Paulo: Ed Perspectiva, 2000.

DEWEY, John. Arte como experiência. São Paulo: Martins Fontes, 2010.

Experiência e educação. Petrópolis: Vozes, 2011.

ESTEVES, Adriana Amélia Pombal Dantas. Os processos criativos na aprendizagem técnica do violoncelo no ensino vocacional de música. 2015. Dissertação (Mestrado) Universidade de Minho, Minho, 2015.

FERRAZ, Sílvio. Cinco duetos para dois violoncelos. São Paulo: Acervo do compositor, 2012, 1 partitura [8 p.]. Violoncelo.

FIALHO, Vania Malagutti; ARALDI, Juciane. Maurice Martenot: Educando com e para a música. In: MATEIRO, Teresa; ILARI, Beatriz (orgs.). Pedagogias em educação musical. Curitiba: Ibpex, 2011.

FICAGNA, Alexandre, Ligetiana. São Paulo: Urbana, 2012, 1 partitura [4 p.]. Violoncelo.

FLICK, Uwe. Uma introdução à pesquisa qualitativa. Porto Alegre: Artmed Editora, 2002.

FONTERRADA, Marisa Trench de Oliveira. De tramas e fios: um ensaio sobre música e educação. São Paulo: UNESP; Rio de Janeiro: Funarte, 2008.

FREIXEDAS, Claudia Maradei. Caminhos criativos no ensino da flauta doce. 2015. $151 \mathrm{f}$. Dissertação (Mestrado em Música) - Escola de Comunicações e Artes, Universidade de São Paulo, São Paulo, 2015.

GADAMER, Hans-George. Verdade e Método: Traços fundamentais de uma hermenêutica filosófica. $3^{\text {a }}$. ed. Petrópolis: 1999.

GAINZA, Violeta Hemsy de. La improvisación musical. Buenos Aires: Melos de Ricordi Americana, 2009.

GALINDO, João Maurício. Instrumentos de arco e ensino coletivo: A construção de um método. 2000, 180 f. Tese (Doutorado em Música) - Escola de Comunicações e Artes, Universidade de São Paulo, São Paulo, 2000.

GIL, Antonio Carlos. Como elaborar projetos de pesquisa. $2^{\text {a }}$ ed. São Paulo: Editora Atlas S.A. 1989. 
GUERVÓS, Luis Enrique de Santiago. A dimensão estética do jogo na filosofia de F. Nietzsche. Cadernos Nietzsche, São Paulo, n. 28, p. 49-72, 2011.

HUIZINGA, Johan. Homo Ludens. 4ª ed. São Paulo: Ed. Perspectiva, 2000.

INSTITUTO BACCARELLI. O Instituto. Instituto Baccarelli: onde a música transforma. São Paulo, 2016. Disponível em <http://-institutobaccarelli.o-rg.br/o-instituto/>. Acesso em: 03 nov. 2018

INSTITUTO FUKUDA. O instituto. Instituto Fukuda. São Paulo, [s.d.]. Disponível em: $<$ http://institutofukuda.com.br/o-instituto/> . Acesso em: 03 nov. 2018.

KIEFER, Bruno. Música para gente miúda. Porto Alegre, 1986, 1 partitura [45p.]. Violão, flauta doce e violino.

KISHIMOTO, Tizuko Morchida. O jogo e a educação infantil. São Paulo: Cengage Learning, 2013.

KOELLREUTTER, Hans-Joachin. Encontro com H.J. Koellreutter. In: KATER, Carlos (org). Cadernos de estudo: Educação musical n ${ }^{\circ} 6$. Belo Horizonte: Através, 1997.

. O ensino da música num mundo modificado. In: KATER, Carlos (org). Cadernos de estudo:Educação musical nº 6 . Belo Horizonte: Através, 1997.

. Sobre o valor e o desvalor da obra musical. In: KATER, Carlos (org). Cadernos de estudo: Educação musical nº 6 . Belo Horizonte: Através, 1997.

LIMA, José Milton de. O jogo como recurso pedagógico no contexto educacional. São Paulo: Cultura Acadêmica, 2008.

MATTHEWS, Wade. Improvisando: La libre creación musical. Madrid: Turner Publicaciones S. L., 2012.

MATTOS, Fernando Lewis. Pluralia Tantum: reflexões sobre a música contemporânea. Revista de Fundarte. Montenegro, ano 16, n. 32, p. 52-94, 2016.

MARIANI, Silvana. Émile Jacques-Dalcroze: A música e o movimento. In: MATEIRO, Teresa; ILARI, Beatriz (orgs.). Pedagogias em educação musical. Curitiba: Ibpex, 2011.

MENEZES, José Amaro de. Creative Process in free improvisation. 2010. 72 f. Dissertação (Mestrado em Psicologia para Músicos) - Department of Music, University of Scheffield, Scheffield, 2010.

MOJOLA, Celso. A música contemporânea e suas fronteiras. Thesis, São Paulo, ano VI, n. 11, p. 1-13, 2009.

MONTANDON, Maria Isabel. Aula de piano e ensino de música: análise da proposta de reavaliação da aula de piano e sua relação com as concepções pedagógicas de Pace, Werhaalen e Gonçalves. 1992. Dissertação (Mestrado em Música)- Instituto de Artes, 
Universidade Federal do Rio Grande do Sul, Porto Alegre, 1992.

MORAES, Abel. Ensino instrumental em grupo: uma introdução. Música Hodie. Belo Horizonte, n. 4, p. 70-77, 1997.

NEGRINE, Airton. Aprendizagem \& Desenvolvimento Infantil: Simbolismo e Jogo. Porto Alegre: Prodil, 1994.

NETTL, Bruno. Un arte relegado por los eruditos In: NETTL, Bruno; RUSSEL, Melinda (orgs.). En el transcurso de la interpretación: Estudios sobre el mundo de la improvisación musical. Madrid: Ediciones Akal, S. A., 2004.

NOGUEIRA, Maryelle Maciente. Aspectos da prática do violoncelo na visão de instrumentistas-educadores. 2008. 220 f. Dissertação (Mestrado em Música) - Escola de Comunicações e Artes- Universidade de São Paulo, São Paulo, 2008.

OLIVEIRA, Enaldo Antonio James de. O ensino coletivo dos instrumentos de corda: reflexão e prática. 1998. 202 f. Dissertação ( Mestrado em Música) - Escola de Comunicações e Artes, Universidade de São Paulo, São Paulo, 1998.

OLIVEIRA, Marcelo Mateus de. A improvisação musical na iniciação coletiva ao violão. 2012. 121 f. Dissertação (Mestrado em Educação) - Faculdade de Educação, Universidade Federal do Ceará, Fortaleza, 2012.

ONOFRE, Marcílio. Estudo 1- Tractus Immobilis I for violoncelo solo. São Paulo: Urbana, 2012, 1 partitura [2 p.]. Violoncelo.

PADOVANI, José; FERRAZ, Silvio. Proto-história, evolução e situação atual das técnicas estendidas na criação musical e na performance. Música Hodie, Belo Horizonte, v. 11, n. 2, p. $11-35,2011$.

PENHA, Gustavo. Nascente. São Paulo: Urbana, 2012, 1 partitura [2 p.]. Violoncelo.

PITOMBEIRA, Liduino. Micro-piece for solo cello. São Paulo: Urbana, 2012, 1 partitura [1 p.]. Violoncelo.

PORENA, Boris. Kindermusik Itália: Famiglia Porena-Bučan, 1 partitura, 2017, 1 partitura [282 p.]. Vários instrumentos e voz.

PRESGRAVE, Fabio Soren. Aspectos de música brasileira atual: Violoncelo. 2008. 190 f. Tese (Doutorado em Música) - Instituto de Artes, Universidade Estadual de Campinas, Campinas, 2008.

RESENDE, Marisa. À Deriva. São Paulo: Urbana, 2012, 1 partitura [2 p.]. Violoncelo.

RODRIGUES, Társilla Castro. Ensino Coletivo de Cordas Friccionadas: uma análise da proposta metodológica de ensino coletivo de violino e viola do programa Cordas da Amazônia. 2012. 103 f. Dissertação (Mestrado Acadêmico em Artes)- Instituto de Ciências da Arte, Universidade Federal do Pará, Belém, 2012. 
RODRIGUES, Vanessa. Movimentações. São Paulo: Urbana, 2012, 1 partitura [2 p.]. Violoncelo.

SALLES, Pedro Paulo. A reinvenção da música pela criança: implicações pedagógicas da criação musical. 2002. 282 f. Tese (Doutorado em Educação) - Faculdade de Educação, Universidade de São Paulo, São Paulo, 2002.

SANTOS, Regina Marcia Simão; Kater, Carlos. O projeto "A Música da Gente": Entrevista com Carlos Kater. Revista Faeba, Salvador, v. 28, n. 48, p. 155-166, 2017.

SCHAFER, Murray. O ouvido pensante. $2^{\text {a }}$ ed. São Paulo: Unesp, 2011.

SILVA, Teresa Cristina Rodrigues; AQUINO, Felipe Avellar de; PRESGRAVE, Fabio Soren. Violoncelo XXI: estudos para aprender a tocar e apreciar a linguagem da música contemporânea. São Paulo: Editora urbana, 2012.

SIQUEIRA, Marcus. Duas linhas em cello e papel de seda. São Paulo: Urbana, 2012, 1 partitura [3 p.]. Violoncelo.

SOUZA, José Pedro da Silva. A improvisação livre: em busca da motivação intrínseca nas crianças, 2014. 84 f. Dissertação (Mestrado em Ensino de Música) - Escola Superior de Artes Aplicadas, Instituto Castelo Branco, Castelo Branco, 2014.

SOUZA, Sanny. A educação musical através do violoncelo. 1998. 37 f. Monografia (Licenciatura em Música) - Centro de Letras e Artes, Universidade do Rio de Janeiro, Rio de Janeiro, 1998.

SUHAMY, Henri. La poétique. Collection: Que sais-je? Paris: Presses Universitaires de France, 1992.

SWANWICK, Keith. Música, pensamiento y educación. $3^{\text {a }}$ ed. Madrid: Ediciones Morata, S.L., 2006.

THIOLLENT, Michel. Metodologia da pesquisa- ação. 14ª ed. São Paulo: Cortez, 2005.

TOURINHO, Cristina. Ensino coletivo de instrumentos musicais: crenças, mitos, princípios e um pouco de história. In: XVI Encontro Nacional da ABEM, 2007. Mato Grosso do Sul. Anais...2007.

TRIPP, David Pesquisa- ação: uma introdução metodológica. Educação e Pesquisa, São Paulo, v. 31, n. 3, p.443-466, 2005.

VILLA-LOBOS, Heitor. Brinquedo de Roda. Rio de Janeiro: Irmãos Vitale S.A, 1912, 1 partitura [1 p.]. Piano.

Piano.

. Carnaval das Crianças. Rio de Janeiro: Arthur Napoleão, 1970, 1 partitura. [35 p].

Cirandinhas: coleção de 12 peças fáceis sobre temas de rodas infantis para piano.

Rio de Janeiro: Arthur Napoleão, [s.d.], 1 partitura [28 p.]. Piano. 
VILLENA, Marcelo Ricardo. Bôôôi !! Porto Alegre: Acervo do compositor, 2013, 1 partitura [10 p.]. Violoncelo.

Paisagens sonoras instrumentais:um processo compositivo através da mímesis de sonoridades ambientais. 2013. 250 f. Dissertação (Mestrado em Música) - Escola de Música, Universidade Federal do Paraná, Curitiba, 2013.

VICTORIO, Roberto. Quatro Estudos. São Paulo: Urbana, 2012, 1 partitura [8 p.]. Violoncelo.

YING, Liu Man. Elaboração de metodologia brasileira para ensino coletivo do violino. In: SANTIAGO, Diana; BROOCK, Angelita; CARVALHO, Tiago (orgs.). Educação Musical Infantil. Salvador: PPGMUS UFBA, 2011.

ZAGONEL, Bernardete. Descobrindo a música contemporânea. In: SCHWANKE. Arte contemporânea em questão. Joinville, UNIVILLE/Instituto Schwanke, 2007.

ZANETTA, Camila Costa. Espaços para criar e conviver: processos criativos em jogos cênicos-musicais na educação musical com crianças. 2014, 176 f. Dissertação (Mestrado em Música) - Escola de Comunicações e Artes, Universidade de São Paulo, São Paulo, 2012.

ZARDO, Fábio. A utilização da improvisação como estratégia no ensino da guitarra flamenca. 2012, 108 f. Dissertação ( Mestrado em Música) - Escola de Comunicações e Artes, Universidade de São Paulo, São Paulo, 2014.

\section{Referências (caderno de anotações, entrevistas e diário de campo)}

CAA- Caderno de Anotações dos Alunos. São Paulo. 2017. Anotações realizadas pelos alunos do Instituto Baccarelli, Projeto Guri-Polo de Indaiatuba e Instituto Fukuda, 29 f, 2017.

CEP- Caderno de Entrevistas aos Professores. São Paulo. 2017. Entrevistas concedidas a Marta Brietzke pelos professores do Instituto Baccarelli, Projeto Guri- Polo de Indaiatuba e Instituto Fukuda, 25 f, 2017.

DCM- Diário de Campo de Marta. São Paulo. 2017. Anotações realizadas durante a pesquisa de campo no Instituto Baccarelli, Projeto Guri Polo de Indaiatuba e Instituto Fukuda, 41 f, 2017. 


\section{APÊNDICES}

\section{Apêndice A - Jogos propostos ao Instituto Baccarelli}

\section{$1^{\circ}$ Encontro:}

- Exploração das possibilidades sonoras do instrumento,

- Improvisação Sinal Verde X Sinal Vermelho (Maria Teresa Alencar de Brito)

Descrição: Os alunos conhecerão alguns dos recursos do violoncelo, bem como diferentes maneiras de tocá-lo, por meio de demonstração prática do professor. Também será encorajado que eles próprios conheçam o violoncelo por intermédio do toque com a ajuda do professor e finalmente sozinhos. Após esse passo, serão encorajados a sozinhos buscarem maneiras de tirar outros sons do violoncelo, que se assemelham às técnicas estendidas. Finalizando, a improvisação consiste em um aluno regente que se posicionará com duas "placas de trânsito", uma verde e uma vermelha, e atuará como regente dos demais alunos, para executar respectivamente sons e silêncios. Podem ser escolhidos um som por aluno em uma versão ou sons livres em outra versão, trabalhando-se também diferentes graus de intensidade ou dinâmica. Os alunos podem se revezar na função de regentes.

Objetivos: Desenvolver liberdade de relacionamento com o instrumento em vários planos, do físico ao mental e emocional, proporcionar conhecimento dos recursos sonoros que o violoncelo possui, trabalhar a diferença entre som e silêncio, trabalhar as diferenças de intensidade e dinâmicas, trabalhar a atenção, a concentração, a criatividade, a liderança e o espírito de equipe, desenvolver a escuta ativa, trabalhar a autoestima e o autoconhecimento.

\section{$2^{\circ}$ Encontro:}

- Improvisação Pergunta e Resposta com cordas soltas em pizzicato (Marta Brietzke)

Descrição: Os alunos serão estimulados a executarem uma improvisação com as cordas soltas do violoncelo em pizzicato. Essa improvisação será em duplas, em pergunta e resposta, sendo que o professor fará a pergunta e o aluno executará a resposta, utilizando diferentes níveis de dinâmica. Os alunos serão encorajados a realizar a improvisação, ora usando uma corda apenas, ora duas ou mais cordas. Posteriormente, os alunos vão se dispor em 
duplas e escolher quem faz a pergunta, quem faz a resposta. Cada dupla se dispõe em um local da sala e faz o exercício. Logo após, as duplas apresentam para os demais colegas.

Objetivos: Desenvolver liberdade de relacionamento com o instrumento em vários planos, trabalhar as diferenças de timbre das diferentes cordas, trabalhar o pizzicato, bem intensidade e dinâmicas, trabalhar a atenção, a concentração, a criatividade, a liderança, o espírito de equipe e autonomia do estudante, desenvolver a escuta ativa, trabalhar a autoestima e o autoconhecimento.

\section{$3^{\circ}$ Encontro:}

- Improvisação A Floresta Encantada (Claudia Freixedas)

Descrição: Será executada a improvisação A Floresta Encantada. Essa improvisação consiste em dispor os instrumentistas em diferentes pontos aleatórios da sala. Cada aluno será uma árvore e irá reproduzir um som escolhido por eles, daqueles inventariados na primeira aula. Um aluno será o viajante. Esse aluno ficará vendado e quando ele se aproximar de cada aluno no papel árvore, ele executará o som correspondente e o aluno viajante terá que mudar de direção. O objetivo é não bater em nenhuma árvore. O aluno viajante, após conhecer o lugar de cada árvore, poderá executar uma espécie de regência, escolhendo os sons que quer ouvir.

Objetivos: Desenvolver a liberdade de relacionamento com o instrumento em vários planos, trabalhar as diferenças de timbre dos diferentes modos de tocar, desenvolver diferentes modos de tocar, desenvolver as diferentes dinâmicas, trabalhar a atenção, a concentração, a criatividade, a liderança, o espírito de equipe e autonomia do estudante, desenvolver a escuta ativa, trabalhar a autoestima e o autoconhecimento.

\section{$4^{\circ}$ Encontro:}

- Improvisação Assinatura Musical (Wanderson Cruz)

Descrição: Os alunos realizarão a improvisação da Assinatura Musical. Nessa improvisação, os alunos são estimulados a criarem com seus instrumentos uma assinatura musical, podendo usar mais de um som dos inventariados. Após cada um criar sua assinatura, eles a apresentarão para seus colegas. Um aluno será o regente e vai escolhendo as assinaturas que quer ouvir, formando um contínuo musical, com uma sequência escolhida por ele. 
Objetivos: Desenvolver liberdade de relacionamento com o instrumento em vários planos, trabalhar as diferenças de timbre dos diferentes modos de tocar, desenvolver diferentes modos de tocar, desenvolver as diferentes dinâmicas, trabalhar a atenção, a concentração, a criatividade, a liderança, o espírito de equipe e autonomia do estudante, desenvolver a escuta ativa, trabalhar a autoestima e o autoconhecimento.

\section{$5^{\circ}$ Encontro:}

- Improvisação A noite no Castelo (Claudia Freixedas)

Descrição: Os alunos realizarão a improvisação A noite no Castelo. Cada aluno escolherá um som para representar algum objeto do castelo. Apagaremos as luzes e inventaremos uma história de um visitante que chegou até o castelo no meio da noite. $\mathrm{O}$ funcionamento é similar ao da Floresta Encantada, mas aqui poderá ser acrescentado mais de um visitante ao mesmo tempo, fazendo uma pequena polifonia.

Objetivos: Desenvolver a liberdade de relacionamento com o instrumento em vários planos, trabalhar as diferenças de timbre dos diferentes modos de tocar, desenvolver diferentes modos de tocar, desenvolver as diferentes dinâmicas, trabalhar a atenção, a concentração, a criatividade, a liderança, o espírito de equipe e autonomia do estudante, desenvolver a escuta ativa, trabalhar a autoestima e o autoconhecimento.

\section{$6^{\circ}$ Encontro:}

- Improvisação O pássaro e o Gavião (Claudia Freixedas)

Descrição: Os alunos realizarão a improvisação O pássaro e o Gavião. Uma pessoa da turma será escolhida para ser o gavião e a turma coletivamente escolherá qual será o som do gavião. Os outros participantes serão os pássaros. Cada um escolherá o som de um pássaro e como representá-lo no violoncelo. Os alunos executarão os sons dos seus pássaros simultaneamente, sendo estimulados a escutar os outros pássaros e dialogar com eles. Quando o urubu chega, todos os pássaros param de cantar. Poderão voltar a cantar em um número de vezes estipulado.

Objetivos: Desenvolver a liberdade de relacionamento com o instrumento em vários 
planos, trabalhar as diferenças de timbre dos diferentes modos de tocar, desenvolver diferentes modos de tocar, desenvolver as diferentes dinâmicas, trabalhar a atenção, a concentração, a criatividade, a liderança, o espírito de equipe e autonomia do estudante, desenvolver a escuta ativa, trabalhar a autoestima e o autoconhecimento.

\section{$7^{0}$ Encontro:}

- Improvisação Igual X Parecido X Diferente (Violeta Gainza)

Descrição: Os alunos realizarão a improvisação Igual $X$ Parecido $X$ Diferente. Os alunos se disporão em fila. O primeiro aluno vai criar uma frase musical, o professor em seguida escolhe um dos cartazes com os dizeres acima e mostra para o segundo aluno, que executará uma nova frase baseada na primeira e com a nova informação, e assim por diante. Posteriormente, os próprios alunos podem definir quem ficará com os cartazes.

Objetivos: Desenvolver a liberdade de relacionamento com o instrumento em vários planos, trabalhar as diferenças de timbre dos diferentes modos de tocar, desenvolver diferentes modos de tocar, desenvolver as diferentes dinâmicas, trabalhar a atenção, a concentração, a criatividade, a liderança, o espírito de equipe e autonomia do estudante, desenvolver a escuta ativa, trabalhar a autoestima e o autoconhecimento, início da associação de sinais para a escrita musical.

\section{$8^{\circ}$ Encontro:}

- Improvisação Passeio no Zoológico (Violeta Gainza)

Descrição: Os alunos realizarão a improvisação Passeio no Zoológico. Cada aluno será um animal e escolherá um ou mais sons para representar aquele animal. Em seguida, imaginarão uma pessoa passeando no zoológico e cada animal vai se manifestar em determinados momentos. Os alunos serão estimulados a ouvir os outros animais e a dialogar, criando momentos de polifonia.

Objetivos: Desenvolver a liberdade de relacionamento com o instrumento em vários planos, trabalhar as diferenças de timbre dos diferentes modos de tocar, desenvolver diferentes modos de tocar, desenvolver as diferentes dinâmicas, trabalhar a atenção, a concentração, a 
liderança, a criatividade, o espírito de equipe e autonomia do estudante, desenvolver a escuta ativa, trabalhar a autoestima e o autoconhecimento

\section{$9^{\circ}$ Encontro:}

- Improvisação Pergunta e Resposta com notas da escala de Ré maior (Marta Brietzke)

Descrição: Os alunos realizarão a improvisação Pergunta e Resposta com notas da escala de Ré maior. Os alunos serão estimulados a executarem pequenas melodias em forma de pergunta e resposta com o professor, utilizando as notas e ritmos aprendidos. Posteriormente, os alunos serão divididos em duplas e cada dupla vai efetuar seus jogos de pergunta e resposta, apresentando em seguida para seus colegas.

Objetivos: Desenvolver a liberdade de relacionamento com o instrumento em vários planos, trabalhar as diferenças de timbre dos diferentes modos de tocar, desenvolver diferentes modos de tocar, desenvolver as diferentes dinâmicas, trabalhar a atenção, a concentração, a liderança, a criatividade, o espírito de equipe e autonomia do estudante, desenvolver a escuta ativa, trabalhar a autoestima e o autoconhecimento.

\section{$10^{\circ}$ Encontro:}

\section{- Composição com gravuras}

- Escrita da composição com notação própria (Marta Brietzke)

Descrição: Os alunos realizarão uma composição coletiva sobre gravuras trazidas por eles mesmos. Serão estimulados a criarem seu próprio sistema de notação.

Objetivos: Desenvolver a liberdade de relacionamento com o instrumento em vários planos, trabalhar as diferenças de timbre dos diferentes modos de tocar, desenvolver diferentes modos de tocar, desenvolver as diferentes dinâmicas, trabalhar a atenção, a concentração, a liderança, a criatividade, o espírito de equipe e autonomia do estudante, desenvolver a escuta ativa, trabalhar a autoestima e o autoconhecimento, estimular a criação e a escrita musical. 


\section{Apêndice B - Jogos propostos ao Projeto Guri-Polo de Indaiatuba}

\section{$1^{\circ}$ Encontro:}

- Apresentação das técnicas estendidas

- Exploração das possibilidades sonoras do Instrumento

- Improvisação Sinal Verde X Sinal Vermelho (Maria Teresa Alencar de Brito)

- Improvisação pergunta e resposta com cordas soltas (Marta Brietzke)

- Improvisação A noite no Castelo (Claudia Freixedas)

Descrição: Os alunos serão encorajados a buscarem maneiras de tirar diferentes sons do violoncelo, que se assemelham às técnicas estendidas. Após esse momento, cada aluno compartilhará com os demais os sons que descobriu. Realizaremos a improvisação Sinal verde $X$ Sinal vermelho que consiste em um aluno regente que se posicionará com duas "placas de trânsito", uma verde e uma vermelha e atuará como maestro dos demais alunos, para executar respectivamente sons e silêncios. Podem ser escolhidos um som por aluno em uma versão ou sons livres em outra versão, trabalhando-se também diferentes graus de intensidade ou dinâmica. Os alunos podem se revezar na função de regentes.

Os alunos serão estimulados a executarem uma improvisação com as cordas soltas do violoncelo em pizzicato. Essa improvisação será em duplas, em pergunta e resposta, sendo que o professor fará a pergunta e o aluno executará a resposta, utilizando diferentes níveis de dinâmica e diferentes ritmos. Os alunos serão encorajados a realizar a improvisação, ora usando uma corda apenas, ora duas ou mais cordas. Posteriormente, os alunos vão se dispor em duplas e escolher quem faz a pergunta, quem faz a resposta. Cada dupla se dispõe em um local da sala e faz o exercício. Logo após, as duplas apresentam para os demais colegas.

Logo após, realizarão a improvisação A noite no Castelo. Cada aluno escolherá um som para representar algum objeto do castelo. Apagaremos as luzes e inventaremos uma história que fez um visitante chegar até o castelo no meio da noite. Um aluno será o viajante, será vendado e entrará no castelo. Quando ele se aproximar de algum colega no papel de objetos do castelo, esse executará o som correspondente ao objeto e o aluno viajante terá que mudar de direção. $\mathrm{O}$ objetivo é não bater em nenhum objeto. $\mathrm{O}$ aluno viajante após conhecer o lugar de cada objeto poderá executar uma espécie de regência, escolhendo os sons que quer ouvir.

Objetivos: Os objetivos de todos os jogos de improvisação são desenvolver a liberdade 
de relacionamento com o instrumento em vários planos, físico, mental e emocional; trabalhar as diferenças de timbre; desenvolver os diferentes modos de tocar; desenvolver as diferentes dinâmicas; trabalhar a atenção; a concentração; a criatividade; a liderança; o espírito de equipe e autonomia do estudante, desenvolver a escuta ativa, trabalhar a autoestima e o autoconhecimento.

\section{$2^{\circ}$ Encontro:}

- Improvisação Assinatura Musical (Wanderson Cruz)

- Improvisação Igual X Parecido X Oposto X Diferente (Violeta Gainza)

- Composição com gravuras

- Escrita da composição com notação própria

Descrição: Os alunos realizarão a improvisação da Assinatura Musical. Nessa improvisação, os alunos são estimulados a criarem com seus instrumentos uma assinatura musical, podendo usar mais de um som dos inventariados. Após cada um criar sua assinatura, eles apresentarão para seus colegas. Um aluno será o regente e vai escolhendo as assinaturas que quer ouvir, formando um contínuo musical, com uma sequência escolhida por ele.

Logo após, os alunos realizarão a improvisação Igual X Parecido X Diferente. Os alunos se disporão em fila. O primeiro aluno vai criar uma frase musical, o professor em seguida escolhe um dos cartazes com os dizeres acima e mostra para o segundo aluno, que executará uma nova frase baseada na primeira e com a nova informação, e assim por diante. Posteriormente, os próprios alunos podem definir quem ficará com os cartazes.

Posteriormente, realizarão uma composição coletiva sobre gravuras trazidas por eles mesmos. Serão estimulados a criarem seu próprio sistema de notação.

Objetivos: Os objetivos de todos os jogos de improvisação são desenvolver a liberdade de relacionamento com o instrumento em vários planos, físico, mental e emocional; trabalhar as diferenças de timbre; desenvolver os diferentes modos de tocar; desenvolver as diferentes dinâmicas; trabalhar a atenção; a concentração; a criatividade; a liderança; o espírito de equipe e autonomia do estudante; desenvolver a escuta ativa; trabalhar a autoestima e o autoconhecimento. 


\section{Apêndice C - Jogos propostos ao Instituto Fukuda}

\section{$1^{\circ}$ Encontro:}

- Apresentação das técnicas estendidas

- Exploração das possibilidades sonoras do Instrumento

- Improvisação Sinal Verde X Sinal Vermelho (Maria Teresa Alencar de Brito)

- Improvisação pergunta e resposta com cordas soltas (Marta Brietzke)

- Improvisação A noite no Castelo (Claudia Freixedas)

Descrição: Os alunos serão encorajados a buscarem maneiras de tirar diferentes sons do violoncelo, que se assemelham às técnicas estendidas. Após esse momento, cada aluno compartilhará com os demais os sons que descobriu. Realizaremos a improvisação Sinal verde $X$ Sinal vermelho que consiste em um aluno regente que se posicionará com duas "placas de trânsito", uma verde e uma vermelha e atuará como maestro dos demais alunos, para executar respectivamente sons e silêncios. Podem ser escolhidos um som por aluno em uma versão ou sons livres em outra versão, trabalhando-se também diferentes graus de intensidade ou dinâmica. Os alunos podem se revezar na função de regentes.

Os alunos serão estimulados a executarem uma improvisação com as cordas soltas do violoncelo em pizzicato. Essa improvisação será em duplas, em pergunta e resposta, sendo que o professor fará a pergunta e o aluno executará a resposta, utilizando diferentes níveis de dinâmica e diferentes ritmos. Os alunos serão encorajados a realizar a improvisação, ora usando uma corda apenas, ora duas ou mais cordas. Posteriormente, os alunos vão se dispor em duplas e escolher quem faz a pergunta, quem faz a resposta. Cada dupla se dispõe em um local da sala e faz o exercício. Logo após, as duplas apresentam para os demais colegas.

Logo após, realizarão a improvisação A noite no Castelo. Cada aluno escolherá um som para representar algum objeto do castelo. Apagaremos as luzes e inventaremos uma história que fez um visitante chegar até o castelo no meio da noite. Um aluno será o viajante, será vendado e entrará no castelo. Quando ele se aproximar de algum colega no papel de objeto do castelo, esse executará o som correspondente ao objeto e o aluno viajante terá que mudar de direção. $\mathrm{O}$ objetivo é não bater em nenhum objeto. $\mathrm{O}$ aluno viajante após conhecer o lugar de cada objeto poderá executar uma espécie de regência, escolhendo os sons que quer ouvir.

Objetivos: Os objetivos de todos os jogos de improvisação são desenvolver a liberdade 
de relacionamento com o instrumento em vários planos, físico, mental e emocional; trabalhar as diferenças de timbre; desenvolver os diferentes modos de tocar; desenvolver as diferentes dinâmicas; trabalhar a atenção; a concentração; a criatividade; a liderança; o espírito de equipe e autonomia do estudante; desenvolver a escuta ativa; trabalhar a autoestima e o autoconhecimento.

\section{$2^{\circ}$ Encontro:}

- Improvisação Assinatura Musical (Wanderson Cruz)

- Improvisação Igual X Parecido X Oposto X Diferente (Violeta Gainza)

- Composição com gravuras

- Escrita da composição com notação própria

Descrição: Os alunos realizarão a improvisação da Assinatura Musical. Nessa improvisação, os alunos são estimulados a criarem com seus instrumentos uma assinatura musical, podendo usar mais de um som dos inventariados. Após cada um criar sua assinatura, eles apresentarão para seus colegas. Um aluno será o regente e vai escolhendo as assinaturas que quer ouvir, formando um contínuo musical, com uma sequência escolhida por ele.

Logo após, os alunos realizarão a improvisação Igual X Parecido X Diferente. Os alunos se disporão em fila. O primeiro aluno vai criar uma frase musical, o professor em seguida escolhe um dos cartazes com os dizeres acima e mostra para o segundo aluno, que executará uma nova frase baseada na primeira e com a nova informação, e assim por diante. Posteriormente, os próprios alunos podem definir quem ficará com os cartazes.

Posteriormente, realizarão uma composição coletiva sobre gravuras trazidas por eles mesmos. Serão estimulados a criarem seu próprio sistema de notação.

Objetivos: Os objetivos de todos os jogos de improvisação são desenvolver a liberdade de relacionamento com o instrumento em vários planos, físico, mental e emocional; trabalhar as diferenças de timbre; desenvolver os diferentes modos de tocar; desenvolver as diferentes dinâmicas; trabalhar a atenção; a concentração; a criatividade; a liderança; o espírito de equipe e autonomia do estudante; desenvolver a escuta ativa, trabalhar a autoestima e o autoconhecimento. 
Apêndice D - Questionário aplicado junto aos alunos

1) Você se sente confortável fazendo os jogos de improvisação?

( ) $\operatorname{sim}$

( ) mais ou menos

( ) não

2) Você acha que o violoncelo consegue "falar" por você durante os jogos de improvisação?

( ) $\operatorname{sim}$

( ) mais ou menos

( ) não

3) Você classifica os jogos de improvisação como música?

( ) $\operatorname{sim}$

( ) mais ou menos

( ) não

4) Você classifica os jogos de improvisação como brincadeira?

( ) $\operatorname{sim}$

( ) mais ou menos

( ) não

5) Você classifica os jogos de improvisação como exercício?

( ) $\operatorname{sim}$

( ) mais ou menos

( ) não

6) Você acha que os jogos de improvisação ajudam você a aprender a tocar violoncelo?

( ) $\operatorname{sim}$

( ) mais ou menos

( ) não

7) Os jogos de improvisação ajudam você a se integrar com seus colegas de classe?
( ) $\operatorname{sim}$
( ) mais ou menos
( ) não 
8) Os jogos de improvisação ajudaram você a entender melhor como se cria uma música?
( ) $\operatorname{sim}$
( ) mais ou menos
( ) não

9) Os jogos de improvisação ajudaram você a escutar músicas "diferentes", que usam "efeitos especiais" dos instrumentos?
( ) $\operatorname{sim}$
( ) mais ou menos
( ) não

10) Você gosta de tocar músicas que utilizem "efeitos especiais"?
( ) $\operatorname{sim}$
( ) mais ou menos
( ) não 


\section{Apêndice E - Roteiro de entrevistas com os professores}

1) Como foi a sua iniciação no violoncelo?

2) Você costuma tocar música contemporânea?

3) Como você trabalha a iniciação no violoncelo?

4) Quais as ferramentas que você usa para trabalhar a criatividade, a expressividade e a musicalidade?

5) Você costuma trabalhar elementos de música contemporânea com os alunos?

6) Qual é a sua opinião sobre os jogos de improvisação que realizamos?

7) Como foi reação dos alunos em relação aos jogos de improvisação?

8) Você considera utilizar algumas das estratégias dos jogos de improvisação em suas aulas?

9) Você acharia interessante um material em que essas técnicas estivessem escritas? 


\section{Apêndice F - Apostila para professores de violoncelo}

\section{Jogos de improvisação em música contemporânea: possibilidades para a iniciação coletiva ao violoncelo}

\section{A música contemporânea:}

O termo música contemporânea, muito utilizado por intérpretes, professores e estudantes de música, carece ainda de uma definição precisa, pois uma das problemáticas que envolve o uso desse termo é a ideia que ele se destinaria a definir toda e qualquer música produzida na atualidade. Para nos ajudar a definir o que se chama comumente nos meios acadêmicos de música contemporânea, recorremos às concepções da professora Bernardete Zagonel. A professora esclarece que, em tais meios, o termo é frequentemente utilizado para designar a música europeia de concerto dos séculos XX e XXI, que foi orientada esteticamente pelas profundas mudanças filosóficas, científicas, culturais e tecnológicas que aconteceram nesse período. Quando nos dispomos a ouvir e a apreciar a música contemporânea precisamos nos despreender de paradigmas antigos e abrir nossas percepções para entender e apreender outras formas de expressão musical. A música contemporânea pode ser definida, então, como a produção musical ligada à música de concerto, vinculada a propostas artísticas formuladas a partir do século XX e marcadas pelas complexidades de diversas referências artísticas, culturais e filosóficas.

Apesar dessas novas características já estarem consolidadas de diferentes maneiras, desde meados do século XX, ainda hoje, com frequência, parte dos músicos profissionais e dos estudantes de música não é familiarizada e, inclusive, não gosta de tocar ou ouvir a música que envolva possibilidades sonoras distintas das consideradas tradicionais (as produzidas nos séculos anteriores). Porém, também desde o século passado, diferentes músicos, compositores, educadores e professores de instrumento, buscam incorporar esse repertório e essas possibilidades sonoras às práticas dos estudantes. Como exemplo dessas iniciativas, podemos citar os trabalhos de Béla Bartók e Boris Porena, e também dos brasileiros Heitor Villa-Lobos, Ernest Mahle e Bruno Kiefer.

A inserção do repertório da música contemporânea nas aulas de instrumento continua sendo reduzida e pouco divulgada. A pouca aceitação desse repertório nas salas de concerto do país pode ainda gerar dúvidas sobre a importância de sua aplicação, sobretudo com os alunos de nível iniciante. Devemos compreender que a aplicação de propostas ligadas às poéticas da música contemporânea aproxima os estudantes das concepções e do pensamento do seu próprio 
tempo, principalmente quando essas propostas estão ligadas a atividades de criação, como o que acontece nas práticas de improvisação. Ao utilizarmos o termo "poética" para nos referirmos à música contemporânea, nos aproximamos de uma concepção que vê a música não apenas como linguagem, mas como uma expressão artística fundamentada nas concepções filosóficas, estéticas, históricas, sociais e políticas do seu entorno e, até mesmo, em elementos biográficos dos artistas. Este termo, utilizado desde a antiguidade pelo filósofo grego Aristóteles, para se referir às obras literárias, passou a ser adotado na contemporaneidade para se referir a outras manifestações artísticas, como por exemplo, as artes visuais, as artes cênicas e a música, se referindo a tudo aquilo que é produzido fazendo uso deliberado de uma composição estética.

Através das propostas da música contemporânea que envolvem a improvisação, trazermos a criação para dentro das salas de aula de instrumento e aproximamos a arte da vida cotidiana, e a "música-pensamento", assim como chamou o poeta Augusto de Campos, do dia a dia dos alunos/intérpretes. Atualmente, a "música-pensamento", ou a "música de invenção", como é algumas vezes chamada, parece estar destinada a uma parcela mínima da população que tem acesso ao ensino musical especializado. Dessa maneira, a abertura às diferentes manifestações musicais, compreendidas como fenômenos socioculturais, parece estar condicionadas a fatores de natureza social e econômica, pouco democráticas e inclusivas. No Brasil, a formação musical nas escolas especializadas, com grande frequência, destina-se quase exclusivamente a investigar e reproduzir repertórios de séculos anteriores aos séculos XX e XXI. Assim, o aluno tende a executar apenas obras do passado, não desenvolvendo seu poder criativo, nem a sua capacidade crítica e reflexiva. Nas principais salas de concerto brasileiras, o espetáculo musical também parece ser direcionado, quase sempre, à apreciação de caráter histórico, sendo desfavorecida a ideia da arte como agente promotor do pensamento crítico e da reflexão.

Cabe a nós, professores de música, em conjunto com compositores e pesquisadores da área, ressaltar o valor da música como produto e produtora de experiências e de pensamento. Para tanto, a execução de obras musicais da atualidade, desde o início da formação do aluno/intérprete é essencial para que possamos trazer a "música-pensamento" para dentro da nossa vida diária.

\section{A improvisação:}

A improvisação é uma prática que se desenvolveu ao longo dos séculos e de diferentes maneiras em muitas culturas, como por exemplo, as culturas indianas, árabes e persas, entre 
outras. Nas culturas europeias, essa prática era comum até meados do século XIX, quando os papeis do compositor e do intérprete começaram a ser delineados como auto excludentes. A prática da improvisação continuou sendo abordada, geralmente nos meios da música popular, em estilos como o jazz, o choro, a salsa, nas manifestações artísticas conhecidas como "livre improvisação", assim como em peças de compositores das poéticas contemporâneas que, algumas vezes, destinam passagens à improvisação dos intérpretes.

Desde meados do século XX, a prática da improvisação tem se mostrado também uma estratégia pedagógica importante para o ensino de música. Porém, essa prática é pouco aplicada nas aulas de instrumento musical, segundo a pesquisadora Chefa Alonso, com exceção dos países nórdicos. Compreender a importância de atividades ligadas à improvisação e algumas propostas de utilização dessa prática nos auxilia, enquanto professores, a elaborar concepções onde essa se inclua nas atividades planejadas para nossas aulas. Os pesquisadores e educadores musicais enfatizam em seus trabalhos e relatos que, por meio de atividades relacionadas à improvisação, é possível apresentar os conteúdos musicais aos alunos, ao mesmo tempo em que a música se torna um veículo para a expressão de percepções, pensamentos e sentimentos.

Desde o trabalho do pesquisador Derek Bailey, que data o ano de 1993, a improvisação começou a ser classificada segundo algumas características relativas ao seu idiomatismo. Apesar do uso desses termos ter sido relativizado pelo próprio pesquisador que os definiu, eles ainda são usados amplamente. É chamada de "improvisação idiomática” a que está ligada a um "idioma" ou estilo musical específico, e de "improvisação não-idiomática" a que não se relaciona com um idioma em particular, mas com o som, com suas possíveis relações e transformações. Dentro das práticas relacionadas como "não-idiomáticas" encontra-se também a "improvisação livre", que abarca uma série de manifestações que se definem como tal. Em comum, essas práticas desenvolvem o foco na performance, que inclui, em maior ou menor grau, uma atuação ativa e criativa em tempo real. Os educadores musicais, na maioria dos casos, abordam em seus processos de ensino e aprendizagem alguns elementos de propostas ligadas à improvisação livre.

A prática da improvisação livre enquanto objeto artístico surgiu na Alemanha e na Inglaterra na década de sessenta do século $\mathrm{XX}$, por meio da criação de diversos grupos dedicados à essa prática. Em paralelo, começou a ser observado pelos educadores musicais que as crianças naturalmente já improvisam livremente e que se essa prática for estimulada, elementos musicais podem ser incorporados às suas vivências e aprendizagem. Os educadores ressaltam alguns dos benefícios da improvisação, entre eles, a aprendizagem de novas formas de relações interpessoais baseadas na igualdade, o aprofundamento da relação com o 
instrumento, a maior compreensão das composições musicais, a necessidade da resolução de problemas que se apresentam como similares aos da vida cotidiana, o desenvolvimento da criatividade, da autoexpressão, da autoestima e da autonomia.

\section{Os jogos na aprendizagem:}

Educadores e pensadores de diversas áreas vêm desenvolvendo ao longo do tempo, ideias a respeito da aprendizagem por meio dos jogos, porém os pesquisadores atuais consideram que essas ideias ainda não estão claras para todas as pessoas que trabalham diretamente com a educação. Um dos motivos dessa confusão diz respeito à característica polissêmica da palavra jogo, que pode ser usada para referenciar atividades com significados diversos. O jogo vem sendo estudado como uma parte natural e essencial do ser humano, parte essencial da aprendizagem e da transmissão de conhecimentos e da própria cultura.

Para os pesquisadores que lidam com a aprendizagem através dos jogos, esses não possuem um "objetivo educacional" determinado, mas consideram que tudo o que aprendemos, aprendemos por intermédio do jogo. Os jogos de improvisação propostos por esse trabalho acompanham essa ideia, não possuem como objetivo o desenvolvimento de conteúdos específicos, e sim, são destinados a trabalharem a natureza lúdica inata das crianças e adolescentes.

\section{O ensino coletivo do violoncelo:}

$\mathrm{Na}$ nossa prática enquanto professores, muitas vezes, encontramos instituições onde o ensino se dá apenas de maneira individual, ou tutorial, e outras onde o ensino acontece coletivamente. No Brasil, na maioria das vezes, o ensino coletivo acontece em instituições ou ONG's onde o fluxo de alunos é constante e é preciso atender a um grande número de alunos ao mesmo tempo, enquanto nas escolas livres ou conservatórios, o ensino é dirigido a uma única pessoa por vez. Porém, a opção pelo ensino coletivo vai além das restrições econômicas, levando-se em consideração seus objetivos e concepções.

Estima-se que o ensino de instrumento em grupo iniciou ainda no século XIX na Inglaterra e posteriormente nos Estados Unidos. No Brasil, ele começou a ser adotado na década de cinquenta do século XX, sendo que, na década de setenta, um grande movimento surgiu para o ensino coletivo de cordas friccionadas, encabeçado por Alberto Jaffé e Dayse de Luca. A partir da disseminação do ensino coletivo de instrumento, pesquisadores iniciaram a investigação sobre os benefícios de tal modelo de ensino, benefícios que, além de musicais, são de ordem psicológica e social. 
No ensino coletivo, acredita-se que é possível compartilhar conhecimento, espaço, e que a interação e a diferença são partes importantes da aprendizagem. Além desses valores, a prática musical em conjunto proporciona a maior diversificação de conteúdos musicais abordados, pois se incluem algumas variáveis que são impossíveis no ensino individual. Cabe ressaltar que o ensino coletivo não deve ser uma cópia do ensino individual, apenas direcionado a mais pessoas ao mesmo tempo. Uma das características do ensino coletivo é que todos os alunos devem estar ativos o tempo todo durante a aula. Para tanto, a atuação do professor também deve ser diferenciada, capaz de agregar todos os alunos em função dos objetivos propostos. As práticas dos jogos de improvisação oferecidas aqui só são possíveis dentro desse contexto, tendo em vista que são direcionadas para a aprendizagem coletiva do instrumento, em associação com os objetivos e concepções desse processo.

\section{Atividades práticas:}

O educador, pesquisador e compositor François Delalande, que integra o grupo francês GRM, fundado por Pierre Schaeffer em 1951, dedicado à música concreta e eletroacústica, através de intensas pesquisas com crianças, aponta que, comumente, ao começar a estudar um instrumento musical, os alunos possuem uma postura semelhante à do compositor de música concreta, ou seja, a necessidade exploratória com fins expressivos dos corpos sonoros, no nosso caso, do violoncelo. Enquanto professores, podemos observar essa necessidade na tendência natural do aluno em percutir, raspar, friccionar e produzir diferentes ações com resultantes sonoras diversas. Podemos observar também que as crianças e adolescentes, na fase inicial do estudo do violoncelo, não possuem preconceitos estéticos como os que são apresentados por alunos ou músicos mais avançados tecnicamente. Os alunos iniciantes aceitam o violoncelo como uma possibilidade infinita de produção de diferentes músicas, com suas multiplicidades estéticas. Tal observação nos leva a concluir que as dificuldades de compreensão da música contemporânea por músicos profissionais é uma dificuldade colocada pela repetição sistemática de determinados estilos musicais, geralmente os pertencentes a música europeia de concerto dos séculos XVIII e XIX.

Sendo assim, pode-se concluir que uma das maneiras de começar a ensinar o repertório de música contemporânea e os jogos de improvisação é permitindo que o aluno exerça sua curiosidade natural em explorar os sons do entorno, entre eles, os sons que podem ser produzidos pelo violoncelo. Ao fazermos isso, podemos utilizar algumas ideias provenientes de alguns compositores de música contemporânea, como a narratividade, a paisagem sonora e a mimese. A mimese é um recurso utilizado por diferentes linguagens artísticas, entre elas, a 
música. Em música, a mimese consiste basicamente na imitação dos fenômenos ambientais ou psicológicos por meio das qualidades do som e da construção de narrativas musicais.

Durante a exploração do violoncelo, a mimese também pode ser usada como recurso pedagógico. Os diferentes sons produzidos pelo violoncelo podem ser relacionados, em conjunto com os alunos, com conteúdos psicológicos e ambientais. Tal abordagem proporciona aos alunos a compreensão de que os sons produzidos por meio das técnicas estendidas, ou seja, as maneiras não-convencionais de abordar o instrumento, não são apenas ruídos, e sim parte importante do leque expressivo musical, sendo que os alunos passam a produzir conteúdos musicais cada vez subjetivos, englobando tanto as técnicas convencionais quanto as técnicas estendidas. Dessa maneira, tornam-se capazes de expressar seus pensamentos, sentimentos e emoções por meio de ideias musicais.

\section{Jogos de improvisação coletiva:}

Descrição do Jogo 1

Pergunta e Resposta com cordas soltas em pizzicato

Autor: Marta Brietzke

Objetivos:

Propiciar aos alunos a consciência da sua individualidade e seu papel dentro do coletivo, estabelecer as ideias de narrativa musical, de perguntas e respostas, enfatizando o uso das quatro cordas do violoncelo, do pizzicato, de diferentes ritmos, métricas, timbres e dinâmicas.

Metodologia e aplicação:

Se inicia o jogo explicando aos alunos o que poderia ser uma pergunta e uma resposta dentro de uma "narrativa" musical. Podemos dar um exemplo com nosso próprio instrumento, utilizando apenas as cordas soltas. Nesse momento, uma boa estratégia para que os alunos compreendam os conceitos de pergunta e resposta é que utilizemos variações de dinâmica ou ritmo.

Em seguida, propomos que cada um dos alunos elabore uma resposta musical a uma pergunta que será feita por nós. O professor executa uma pergunta e o primeiro aluno executa uma resposta. Em seguida, o professor executa outra pergunta e o segundo aluno executa uma resposta e assim sucessivamente, até que todos os alunos tenham participado do jogo. Podemos fazer quantas rodadas acharmos necessário, dependendo de cada turma ou grupo de alunos. As perguntas podem englobar diferentes dinâmicas, ritmos e métricas, a fim de que os alunos sejam estimulados de diferentes maneiras.

Logo após, propomos que os alunos se distribuam em duplas e que escolham quem vai fazer a pergunta e quem vai fazer a resposta. Cada dupla se dispõe em um local da sala e é importante que os alunos tenham experiência em ambos os papéis. A ideia é que após esse momento, os alunos possam "apresentar", em duplas, para os demais colegas uma série de perguntas e respostas elaboradas por eles. 
É importante que possibilitemos uma certa autonomia aos alunos. É interessante que deixemos a sua escolha definir quantas perguntas e respostas querem apresentar aos colegas, quem inicia perguntando, que sinal vão combinar para o início e o final das sessões de perguntas e respostas. Com frequência, vamos observar um aumento na complexidade das perguntas e respostas feitas pelos alunos em relação àquelas elaboradas no início do jogo.

Fonte: elaborado pela autora.

Descrição do Jogo 2

Sinal Verde X Sinal Vermelho

Autor: Maria Teresa Alencar de Brito/Murray Schafer

Objetivos:

Trabalhar as diferenças entre som e silêncio, bem como sua importância e papel dentro da construção musical; aprofundar a importância da coletividade dentro do processo musical; estabelecer a ideia de diálogo musical.

Metodologia e aplicação:

Antes da sua realização, podemos propor aos alunos que explorem as diferentes sonoridades dos seus violoncelos. Uma das maneiras de realizar essa prática é por meio da imitação, propomos um som e pedimos que os alunos repitam, em conjunto ou individualmente, esse mesmo som. É interessante que possamos nomear as técnicas que já apresentam um nome definido pela literatura, como por exemplo, con legno, sul ponticelo, pizzicato Bartók. É importante que abramos espaço para que os alunos descubram seus próprios sons, destinando uma parte dessa exploração para que eles abordem sozinhos seus instrumentos. Podemos pedir para que cada um demonstre aos demais colegas um som que descobriu, a fim, novamente, de dar voz ao aluno, e, posteriormente, todos repetem aquele som.

Podemos também escolher alguns desses sons e compartilhá-los com os alunos, se considerarmos que a aprendizagem de todos os sons no mesmo dia pode causar alguma dificuldade de assimilação por parte dos alunos. Posteriormente, nas próximas aulas, podemos introduzir mais alguns desses sons, a fim de aumentar o leque expressivo dos estudantes. Em alguns grupos de alunos, que ainda não sabem segurar o arco, podemos oferecer esses mesmos sons, propondo que os alunos segurem o arco "abraçando-o" no talão. Dessa maneira, os alunos ficarão confortáveis e não vão adquirir vícios posturais. A maioria dos sons podem ser produzidos com a "pegada" do arco dessa maneira, possibilitando que os jogos sejam desenvolvidos em paralelo com a aquisição técnica dos alunos.

Após a exploração do instrumento, mostramos aos alunos dois pequenos cartazes, um verde e um vermelho. Associamos esses cartazes às regras de trânsito, em que o verde significa seguir ou, então, tocar, e o vermelho significa parar ou não tocar. Podemos propor que os alunos escolham, cada um, um dos sons inventariados anteriormente, ou então que produzam diferentes sons. Ao ser apresentado o sinal verde, os alunos devem executar um som no seu violoncelo, ao ser apresentado o sinal vermelho, os alunos devem fazer uma pausa. Dessa maneira, estabelecemos a importância e a função do silêncio na perspectiva musical.

É interessante proporcionar aos alunos a experiência de ser o "maestro", ou seja, a pessoa que vai escolher quando se faz som, quando se faz silêncio. Após algumas rodadas do jogo, podemos distribuir mais um sinal verde e um sinal vermelho, estabelecendo dois "maestros" e dividindo o grupo em dois. Cada grupo deve seguir as orientações do seu maestro específico, o que resultará em diálogos musicais entre os dois grupos e uma sonoridade mais complexa.

Os maestros devem se comunicar entre si para definir o início e o fim da música, cabendo a nós, estabelecermos que essa comunicação deve ser não verbal. Devemos salientar, nessa fase do 
jogo, que é importante que, tantos os maestros quanto os executantes escutem as diferentes sonoridades produzidas pelo grupo e se tornem conscientes da "narrativa" musical que está sendo criada. Os maestros devem ser incentivados a criarem, junto com os sinais verde e vermelho, sinais de variação de dinâmicas, de articulação e de caráter. Por exemplo, abaixar o sinal pode indicar tocar mais piano, levantar o sinal pode significar tocar mais forte. Devemos estar atentos e estimular que o poder de escuta dos alunos vá se aprofundando em cada rodada do jogo, evitando que ele se torne mecânico e repetitivo.

Também é interessante nesse momento que mostremos a gravação de alguma peça musical que utilize técnicas estendidas, como por exemplo, a peça Pression de Helmut Lachenmann, disponível em várias versões no site youtube. Tal audição aproxima o trabalho realizado pelos estudantes com o trabalho realizado por outras pessoas, o que é importante para que os alunos valorizem sua própria produção e as dos demais. Outra peça interessante são as improvisações por senhas executadas pelo grupo de violoncelistas argentinos ARRE! Algumas dessas improvisações também estão disponíveis no site youtube e proporcionam ao aluno a escuta de diferentes sonoridades, sendo produzidas por grupo de violoncelos, e assim como em Lachenmann, aproximam o trabalho realizado pelos estudantes com o que vem sendo produzido pelos músicos da atualidade.

Fonte: Elaborado pela autora, com base nas propostas de Maria Teresa Alencar de Brito e Murray

Schafer.

Descrição do Jogo 3

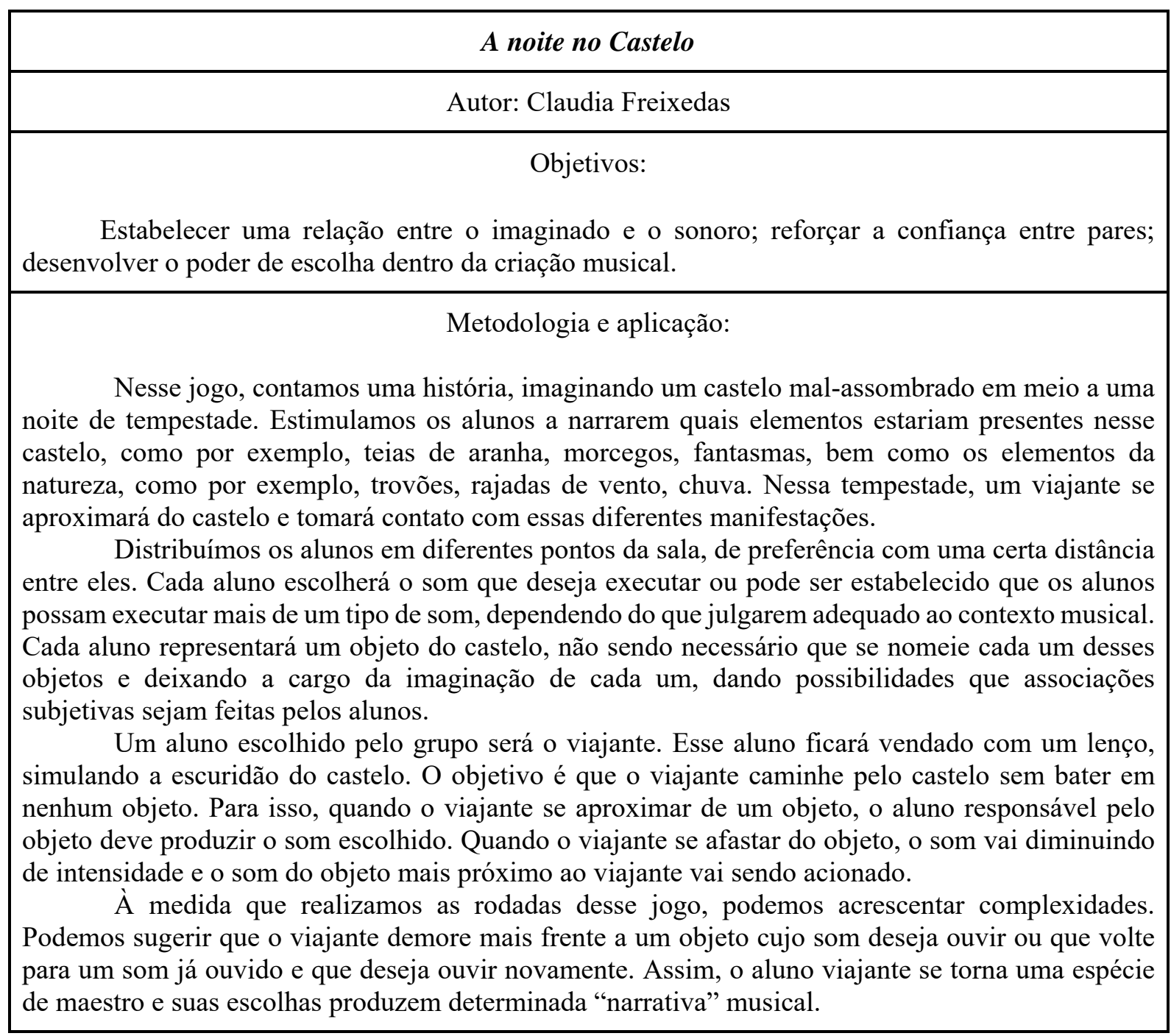


É interessante que se faça uma gravação em áudio ou vídeo da improvisação que posteriormente se escute essa gravação em conjunto e se discuta sobre o resultado. A audição da peça inteira proporciona a todos os participantes a ideia geral da proposta musical produzida. Algumas vezes, os alunos envolvidos na execução podem perder a noção do todo musical e essa audição é fundamental para que os alunos percebam que não estão sendo produzidos apenas ruídos desconexos e sim, um "caminho" musical.

Fonte: Elaborado pela autora, com base nas propostas de Claudia Freixedas.

Descrição do Jogo 4

\section{Assinatura Musical}

Autor: Wanderson Cruz

Objetivos:

Possibilitar a experiência de criação a partir de células musicais pré-estabelecidas; proporcionar diferenças entre as polifonias e homofonias; incentivar o poder de escolha dentro da criação musical.

\section{Metodologia e aplicação:}

Iniciamos perguntando para os alunos o que é uma assinatura. Logo após, relacionamos essa resposta com o que seria uma "assinatura musical". Podemos dar um exemplo com nosso próprio instrumento, sendo interessante que utilizemos sons convencionais e sons provenientes das técnicas estendidas.

Propomos então aos alunos que cada um crie sua própria assinatura musical utilizando para isso os sons que desejarem. Damos um tempo para que os alunos façam essa pesquisa e escolham individualmente sua assinatura. Logo após, propomos que cada aluno execute a sua assinatura para os demais colegas do grupo, a fim de que todos possam conhecer todas as assinaturas. É interessante que peçamos aos alunos que executem mais de uma vez a sua assinatura, para que possamos verificar se ele está mantendo sempre a mesma assinatura ou se a cada vez executa uma assinatura diferente. Nesse jogo, propomos que as assinaturas de cada aluno sejam sempre as mesmas.

Após a apresentação dos alunos, sugerimos a composição de uma peça utilizando as assinaturas musicais de cada um dos alunos. Escolhemos um maestro para que organize a composição. O maestro executa sinais com as mãos e com o corpo indicando quando cada aluno deve tocar sua assinatura, com que dinâmica e quando deve parar de tocar. A ideia é que enquanto o maestro não der um sinal para parar de tocar, as assinaturas vão sendo executadas continuamente. Ao terminar sua assinatura, o aluno recomeça do princípio até que receba um sinal para parar.

Devemos estimular os alunos a trabalharem sua escuta e sua escolha artística frente ao material apresentado pelos colegas. Dessa forma, evitamos novamente que o jogo se torne mecânico e proporcionamos a construção de uma ideia musical consistente.

É interessante, em todos os jogos, que o professor seja o maestro na primeira vez que o jogo está sendo executado, mas que em seguida sejam escolhidos diferentes alunos para assumirem essa função, possibilitando que todos os alunos do grupo possam, em algum momento, participar como maestros de algum dos jogos de improvisação.

Fonte: Elaborado pela autora, com base nas propostas de Wanderson Cruz. 
Descrição do Jogo 5

\begin{tabular}{|c|}
\hline Igual $\boldsymbol{X}$ Parecido $\boldsymbol{X}$ Diferente \\
\hline Autor: Violeta Gainza \\
\hline Objetivos: \\
\hline $\begin{array}{c}\text { Trabalhar as ideias de similaridade e diferença em música; proporcionar a criação a partir de } \\
\text { um elemento dado previamente; trabalhar a ideia de frases ou narrativas musicais. }\end{array}$ \\
\hline Metodologia e aplicação: \\
Apresentamos aos alunos três pequenos cartazes. No primeiro cartaz, apresentamos o sinal \\
matemático utilizado para igual, no segundo o sinal matemático utilizado para diferente e no terceiro \\
cartaz podemos criar algum sinal que represente o parecido. Propomos aos alunos que eles devem \\
respeitar os sinais que serão oferecidos a eles. O primeiro aluno cria livremente uma frase musical, \\
em seguida o professor apresenta um dos sinais ao segundo aluno, que deve repetir ou variar a frase \\
de acordo com o sinal representado. O professor oferece então um novo sinal ao terceiro aluno, que \\
agora deve repetir ou variar a frase apresentada pelo segundo aluno, e assim sucessivamente, até que \\
todos os alunos tenham elaborado suas frases. Os sinais podem ser escolhidos aleatoriamente ou \\
selecionados previamente pelo professor. \\
Em seguida, propomos que um dos alunos seja o maestro e faça as indicações dos cartazes \\
aos seus colegas. Podemos acrescentar complexidades ao jogo propondo que o maestro, além de \\
escolher o próximo cartaz que oferecerá aos colegas, escolha também, sempre de maneira não verbal, \\
o aluno que executará a próxima variação da frase.
\end{tabular}

Fonte: Elaborado pela autora, com base nas propostas de Violeta Gainza.

Descrição do Jogo 6

\section{Composição com gravuras e escrita com notação própria}

Autor: Diversos autores/Marta Brietzke

Objetivos:

Aproximar os alunos da ideia de composição; desenvolver uma simbologia própria que represente suas ideias musicais, fazer contato com diferentes maneiras de escrita e representação musical; atentar para as limitações existentes em qualquer tipo de escrita musical; aproximar compositores. e intérpretes.

\section{Metodologia e aplicação:}

Para o jogo de composição com gravuras solicitamos na aula anterior que os alunos tragam gravuras de revistas ou fotos pessoais. Porém, é interessante que o professor traga algumas gravuras selecionadas previamente, pois algumas vezes os alunos esquecem de trazê-las e a atividade fica comprometida. Também é necessário que o professor traga cartazes de cartolina e jogos de lápis de cor. Também podemos acrescentar outros materiais, conforme nossa disponibilidade, como por exemplo, palitos de dente, fitas coloridas, cordões de espessuras diversas, pedrinhas, etc. 
Começamos o jogo dividindo a turma em grupos. Cada grupo irá apresentar suas gravuras e fotos para os demais colegas e o professor poderá distribuir mais gravuras aos alunos. Propomos, então, que os alunos escolham uma ou mais gravuras ou fotos, quantas desejarem, para que contem uma história musical. Podemos dar um exemplo com nosso próprio violoncelo escolhendo uma das gravuras. Devemos ressaltar que a história deve ter um enredo, um início, meio e fim e que os alunos devem discutir e elaborar em conjunto esse enredo, de acordo com a(s) gravura(s) que escolherem.

Após a elaboração do enredo, estimulamos que os alunos produzam com os seus violoncelos conteúdos musicais que representem a história criada por eles, estimulando que a história pode ser contada em partes, ou mesmo simultaneamente, dependendo das escolhas feitas pelos alunos. A seleção desses conteúdos deve ser feita em conjunto pelos grupos e podemos dar a eles quanto tempo acharmos necessário para que pesquisem e selecionem os sons desejados.

Num terceiro momento do jogo, distribuímos os cartazes, os lápis coloridos e os demais materiais e propomos que os alunos criem uma maneira de "escrever" a música inventada por eles. Essa escrita pode utilizar desenhos, cores, símbolos, palavras, dependendo do que cada grupo achar conveniente. Podemos sugerir que escolham um título para sua peça, que coloquem seus nomes como compositores ou podemos nem mencionar tais aspectos, dando liberdade para que cada grupo determine o que julgar necessário para a compreensão da peça.

Quando os alunos terminarem sua escrita, solicitamos que, em conjunto, utilizando ou não a partitura, ensaiem a peça criada por eles. Devemos dar autonomia para que eles estabeleçam entre si sinais para o início e fím da música, sinais de dinâmica e outras informações que sintam necessidade. Após alguns ensaios, propomos um momento de apresentação das peças para os colegas do outro grupo.

Podemos sugerir que os alunos contem sua história e depois executem a peça ou que executem a peça e depois contem sua história, ou apenas que mostrem as gravuras escolhidas por eles para a criação das suas peças, dependendo do que julgarmos interessante no momento. É importante que nesse momento também proporcionemos autonomia aos alunos na sua organização e apresentação aos demais colegas.

Fonte: Elaborado pela autora.

Descrição do Jogo 7

\begin{tabular}{|c|}
\hline \multicolumn{1}{|c|}{ Improvisação com ostinato } \\
\hline Autor: Vários autores/Marta Brietzke \\
\hline \multicolumn{1}{c|}{ Objetivos: } \\
$\begin{array}{c}\text { Trabalhar a noção de solo e tutti; trabalhar a ideia de ostinato; trabalhar o conceito de forma } \\
\text { musical. }\end{array}$ \\
\hline \multicolumn{1}{|c|}{ Metodologia e aplicação: } \\
Iniciamos esse jogo de improvisação explicando aos alunos o que é um ostinato. Logo após, \\
$\begin{array}{l}\text { propomos algum ostinato rítmico a ser executado por todos os alunos com a corda solta ré, em } \\
\text { pizzicato. Esse ostinato deve ser simples, como por exemplo, uma semínima seguida de duas } \\
\text { colcheias. } \\
\text { Propomos, então, aos alunos que o grupo se divida em orquestra e solista. O grupo que } \\
\text { representará a orquestra executará o ritmo ostinato com corda solta ré, enquanto o aluno escolhido } \\
\text { para ser solista executará diferentes frases, englobando os conhecimentos musicais e técnicos já } \\
\text { aprendidos por eles. Não é necessário, nesse momento, que se pense em harmonia ou condução vocal, } \\
\text { pois a improvisação não necessita obedecer aos padrões estéticos do tonalismo. O objetivo é que os } \\
\text { alunos possam utilizar livremente seus conhecimentos musicais e organizar suas ideias tendo como } \\
\text { ponto de partida um ritmo em ostinato. }\end{array}$ \\
\hline
\end{tabular}


Podemos organizar a improvisação de diferentes maneiras, como por exemplo, estabelecendo que vamos executar duas vezes o ritmo em ostinato após o término de cada solo, para que o próximo executante identifique a sua hora de entrar como solista na execução. Também podemos organizar a improvisação na forma rondó, propondo que a parte A seja algum número específico de vezes da repetição do ostinato ou algum tema criado em conjunto pelo grupo, a ser executado pelo solista antes da sua livre improvisação. Organizamos e acrescentamos complexidade ao jogo no decorrer das jogadas, que podem ser intercaladas com sessões de audição coletiva da gravação das improvisações.

Fonte: Elaborado pela autora.

Descrição do Jogo 8

\begin{tabular}{|c|}
\hline A floresta encantada \\
\hline Autor: Claudia Freixedas \\
\hline Objetivos: \\
\hline Trabalhar o diálogo musical; trabalhar a ideia de polifonia. \\
\hline Metodologia e aplicação: \\
Consiste em uma variação do jogo A noite no Castelo, com um acréscimo de complexidade. \\
$\begin{array}{c}\text { Nesse caso, também criamos uma história na qual dois exploradores chegam a uma floresta encantada. } \\
\text { Nessa floresta, cada árvore emite um som diferente. Quando os exploradores se aproximam das } \\
\text { árvores, elas emitem o seu som. Podemos realizar esse jogo com os olhos abertos ou vendados, de } \\
\text { forma semelhante à do jogo A noite no Castelo e as árvores podem emitir um único som ou diferentes } \\
\text { sons conforme o contexto musical. Porém, é interessante propormos algumas diferenças entre este } \\
\text { jogo e o jogo anterior. } \\
\text { Nesse jogo, uma das complexidades a serem apresentadas aos alunos é que mais de um } \\
\text { explorador entra na floresta ao mesmo tempo. Tal característica proporcionará a existência de um } \\
\text { diálogo a ser "composto" pelos exploradores, que também atuarão como maestros. }\end{array}$ \\
\hline
\end{tabular}

Fonte: Elaborado pela autora, com base nas propostas de Claudia Freixedas.

Descrição do Jogo 9

\begin{tabular}{|c|}
\hline Passeio no zoológico \\
\hline Autor: Violeta Gainza \\
\hline Objetivos: \\
$\begin{array}{c}\text { Trabalhar diferentes opções musicais de uma mesma sonoridade, trabalhar a ideia de narrativa } \\
\text { musical. }\end{array}$ \\
\hline Metodologia e aplicação: \\
$\begin{array}{l}\text { Nesse jogo, também criamos, em conjunto com os alunos, uma história de um visitante em um } \\
\text { zoológico. O visitante passeia pelo zoológico e observa os diferentes animais. Cada aluno escolherá } \\
\text { um animal para representar com seu violoncelo. O visitante escolherá qual animal quer visitar se } \\
\text { posicionando na frente de cada um dos colegas que estará representando-o. }\end{array}$ \\
\hline
\end{tabular}


Nesse jogo, podemos acrescentar a interação do visitante com os animais. Conforme essa interação ocorra, o animal pode se manifestar com diferentes caracteres musicais, utilizando diferentes dinâmicas, articulações, ritmos, nuances timbrísticas ou organização dos conteúdos em forma de frases musicais.

Assim, como citado anteriormente, podemos gravar as improvisações resultantes, aumentando o poder de escuta e análise dos estudantes, possibilitando que nas próximas rodadas dos jogos as interações musicais sejam, cada vez mais, provenientes da escolha artística dos alunos. Devemos sempre evitar que a execução dos jogos se torne uma atividade mecânica e desprovida de análise crítica, pois, nesse caso, perdemos uma importante estratégia de desenvolvimento musical dos alunos.

Fonte: Elaborado pela autora, com base nas propostas de Violeta Gainza.

Descrição do Jogo 10

\begin{tabular}{|l|}
\hline Os pássaros e o caçador \\
\hline Autores: Claudia Freixedas/Marta Brietzke \\
Objetivos: \\
Trabalhar a liberdade e as diferentes opções para o início, o desenvolvimento e o final da \\
"peça" musical, trabalhar questões ligadas à ecologia e à ecologia acústica; trabalhar os diálogos, as \\
polifonias e a noção de forma musical. \\
Metodologia e aplicação: \\
Nesse jogo, perguntamos aos alunos quais sons de pássaros eles conhecem. Podemos \\
inventariar coletivamente esses sons ou nos propormos a investigar em nossas casas e trazermos os \\
resultados de nossas investigações aos demais colegas. Também podemos trazer um catálogo da \\
gravação de sons de pássaros que podemos obter em sites da internet. Dessa forma, escolhemos alguns \\
pássaros que desejamos imitar e buscamos sonoridades semelhantes em nossos violoncelos. \\
Após a escolha dos sons dos pássaros, cada aluno se torna responsável pela emissão de um \\
desses sons, representando uma espécie de pássaros. Em seguida, escolhemos em conjunto um som \\
representativo que imite o som produzido pelo caçador. Esse som pode ser o som de um rifle \\
disparando, da caminhada do caçador pela mata ou do que a imaginação dos alunos determinar. \\
Propomos, então, que na mata onde se encontram os pássaros, cada um deles atue de forma a \\
dialogar com os demais pássaros, criando conscientemente um conteúdo sonoro. Um aluno será \\
responsável por executar o som do caçador. Todos os pássaros, ao ouvirem o som do caçador, calam- \\
se por um momento. Em seguida, não havendo mais perigo, os pássaros pouco a pouco voltam a \\
cantar, novamente estabelecendo um diálogo com os demais pássaros da mata. \\
O caçador pode intervir na mata o número de vezes que desejar e com a frequência que \\
desejar. Também devemos dar autonomia para que o próprio grupo sinta o tempo necessário de \\
silêncio após a intervenção do caçador, o momento de iniciar a improvisação e o momento de finalizá- \\
la. Dessa maneira, ampliamos a percepção do grupo em relação à atuação e à participação de cada um \\
no todo musical.
\end{tabular}

Fonte: Elaborado pela autora, com base nas propostas de Claudia Freixedas.

\section{Sugestão de repertório:}

A fim de contextualizarmos o trabalho com os jogos de improvisação dentro das poéticas da música contemporânea e oferecermos subsídios aos alunos, podemos apresentar, 
em diferentes momentos, peças do repertório dos séculos XX e XXI, compostas para violoncelo. O objetivo da audição de tais peças é que os alunos possam identificar elementos comuns dessas peças com as suas próprias criações e assim valorizem mais o seu trabalho e o trabalho dos compositores apresentados.

Relação de peças do repertório contemporâneo para violoncelo

\begin{tabular}{|l|}
\hline Lachenmann, Helmut - Pression para violoncelo solo \\
\hline ARRE! - Improvisações por senhas para grupo de violoncelos \\
\hline Penderecki, Kristof - Capriccio per Siegfried Palm, para violoncelo solo \\
\hline Berio, Luciano - Sequenza XIV, para violoncelo solo \\
\hline Boulez, Piérre - Messagesquisse, para violoncelo solo e seis violoncelos \\
\hline Saraaiaho, Kaija - Sept Papillons, para violoncelo solo \\
\hline Ligeti, Györgi - Sonata, para violoncelo solo \\
\hline Romitelli, Fausto - Professor Bad Trip- lesson II- cadência para violoncelo \\
\hline Furrer, Beat - Solo für cello, para violoncelo solo \\
\hline Scelsi, Giancinto - Trilogia , para violoncelo solo \\
\hline Crumb, George - Sonata para Violoncelo, para violoncelo solo \\
\hline Kagel, Maurício - Match, para dois violoncelos e percussão \\
\hline Sciarrino, Salvatore - Variazoni, para violoncelo e orquestra \\
\hline Saunders, Rebecca - Solitude, para violoncelo solo \\
\hline Rihm, Wolfgang - Von Weit, para violoncelo e piano \\
\hline Ginastera, Alberto - Puneña, para violoncelo solo \\
\hline Gras, Germán - Solo para Marta, para violoncelo solo \\
\hline Kiefer, Bruno - Errância, para violoncelo solo \\
\hline Santoro, Claúdio - Fantasia Sulamérica, para violoncelo solo \\
\hline Nobre, Marlos - Desafio, para violoncelo e orquestra \\
\hline Lima, Rodrigo - Circuncello, para violoncelo e orquestra \\
\hline Ferraz, Sílvio - Lamento quase mudo, para violoncelo solo \\
\hline Angelo, Bruno - Traçado íntimo e hesitante, para violoncelo solo \\
\hline
\end{tabular}

Fonte: Elaborado pela autora.

\section{Para saber mais:}

Relação de livros sobre os temas tratados

ALONSO, Chefa. Improvisación libre: la composición en movimiento. Baiona: Editorial Dos acordes S. L., 2007.

DELALANDE, François. La música es un juego de niños. Buenos Aires: Ricordi Americana, 2001. COSTA, Rogério. Música errante: o jogo da improvisação livre. São Paulo: Perspectiva: Fapesp, 2016.

GAINZA, Violeta. La improvisación musical. Buenos Aires: Melos de Ricordi Americana, 2009. KISHIMOTO, Tizuko Morchida. O jogo e a educação infantil. São Paulo: Cengage Learning, 2013. MATTHEWS, Wade. Improvisando: La libre creación musical. Madrid: Turner Publicaciones S. L., 2012.

TOURINHO, Cristina, TOURINHO, Cristina. Ensino coletivo de instrumentos musicais: crenças, mitos, princípios e um pouco de história. In: XVI Encontro Nacional da ABEM, 2007. Mato Grosso do Sul. Anais...2007.

Fonte: Elaborado pela autora. 


\section{Apêndice G - Termo de consentimento livre e esclarecido}

\section{TERMO DE CONSENTIMENTO LIVRE E ESCLARECIDO}

Prezado (a) Senhor (a)

Esta pesquisa é sobre Jogos de Improvisação livre na iniciação coletiva ao violoncelo e está sendo desenvolvida por Marta Brietzke do Curso de Pós-Graduação em Música da Universidade de São Paulo, sob a orientação do Prof Fabio Presgrave. Os objetivos do estudo são verificar a funcionalidade de jogos de improvisação para a iniciação ao violoncelo. A finalidade deste trabalho é contribuir para o desenvolvimento do ensino coletivo do violoncelo. Solicitamos a sua colaboração para a realização de uma entrevista de uma hora de duração como também sua autorização para apresentar os resultados deste estudo. Por ocasião da publicação dos resultados, seu nome será mantido em sigilo absoluto. Informamos que essa pesquisa não apresenta riscos. Esclarecemos que sua participação no estudo é voluntária e, portanto, o(a) senhor(a) não é obrigado(a) a fornecer as informações e/ou colaborar com as atividades solicitadas pelo Pesquisador(a). Caso decida não participar do estudo, ou resolver a qualquer momento desistir do mesmo, não sofrerá nenhum dano. Os pesquisadores estarão a sua disposição para qualquer esclarecimento que considere necessário em qualquer etapa da pesquisa.

\section{Assinatura do(a) pesquisador(a) responsável}

Considerando, que fui informado(a) dos objetivos e da relevância do estudo proposto, de como será minha participação, dos procedimentos e riscos decorrentes deste estudo, declaro o meu consentimento em participar da pesquisa, como também concordo que os dados obtidos na investigação sejam utilizados para fins científicos (divulgação em eventos e publicações). Estou ciente que receberei uma via desse documento.

São Paulo, de de 


\title{
Apêndice H - Autorização solicitada ao Instituto Baccarelli
}

\section{Autorização}

\begin{abstract}
Autorizo o menor
a participar da pesquisa " $O$

Violoncelo e os Jogos de Improvisação”, a ser realizada no Instituto Baccarelli, pela violoncelista e pesquisadora Marta Brietzke, sob orientação do professor Dr. Fábio Presgrave para a Universidade de São Paulo (USP). Estou ciente de que tal pesquisa faz parte do trabalho de mestrado da referida pesquisadora e que seus resultados, bem como os materiais produzidos, farão parte da dissertação a ser apresentada para a conclusão do curso de mestrado no PPGMUS, área de concentração Processos de criação musical, linha de pesquisa Música e educação: processos de criação, ensino e aprendizagem. Autorizo a divulgação dos resultados nesta dissertação.
\end{abstract}

São Paulo, de 2017.

Nome:

RG ou CPF:

Assinatura: 


\title{
Apêndice I - Autorização solicitada ao Projeto Guri
}

\section{Autorização}

\begin{abstract}
Autorizo o menor
a participar da pesquisa " $O$

Violoncelo e os Jogos de Improvisação", a ser realizada no Projeto Guri, pela violoncelista e pesquisadora Marta Brietzke, sob orientação do professor Dr. Fábio Presgrave para a Universidade de São Paulo (USP). Estou ciente de que tal pesquisa faz parte do trabalho de mestrado da referida pesquisadora e que seus resultados, bem como os materiais produzidos, farão parte da dissertação a ser apresentada para a conclusão do curso de mestrado no PPGMUS, área de concentração Processos de criação musical, linha de pesquisa Música e educação: processos de criação, ensino e aprendizagem. Autorizo a divulgação dos resultados nesta dissertação.
\end{abstract}

São Paulo, de 2017.

Nome:

RG ou CPF:

Assinatura: 


\section{Apêndice J - Autorização solicitada ao Instituto Fukuda}

\section{Autorização}

Autorizo o menor

a participar da pesquisa " $O$

Violoncelo e os Jogos de Improvisação”, a ser realizada no Instituto Fukuda, pela violoncelista e pesquisadora Marta Brietzke, sob orientação do professor Dr. Fábio Presgrave para a Universidade de São Paulo (USP). Estou ciente de que tal pesquisa faz parte do trabalho de mestrado da referida pesquisadora e que seus resultados, bem como os materiais produzidos, farão parte da dissertação a ser apresentada para a conclusão do curso de mestrado no PPGMUS, área de concentração Processos de criação musical, linha de pesquisa Música e educação: processos de criação, ensino e aprendizagem. Autorizo a divulgação dos resultados nesta dissertação.

São Paulo, de 2017.

Nome:

RG ou CPF:

Assinatura: 


\section{ANEXOS}

\section{Anexo A - Partituras criadas pelos alunos na atividade Composição com gravuras e escrita com notação própria}

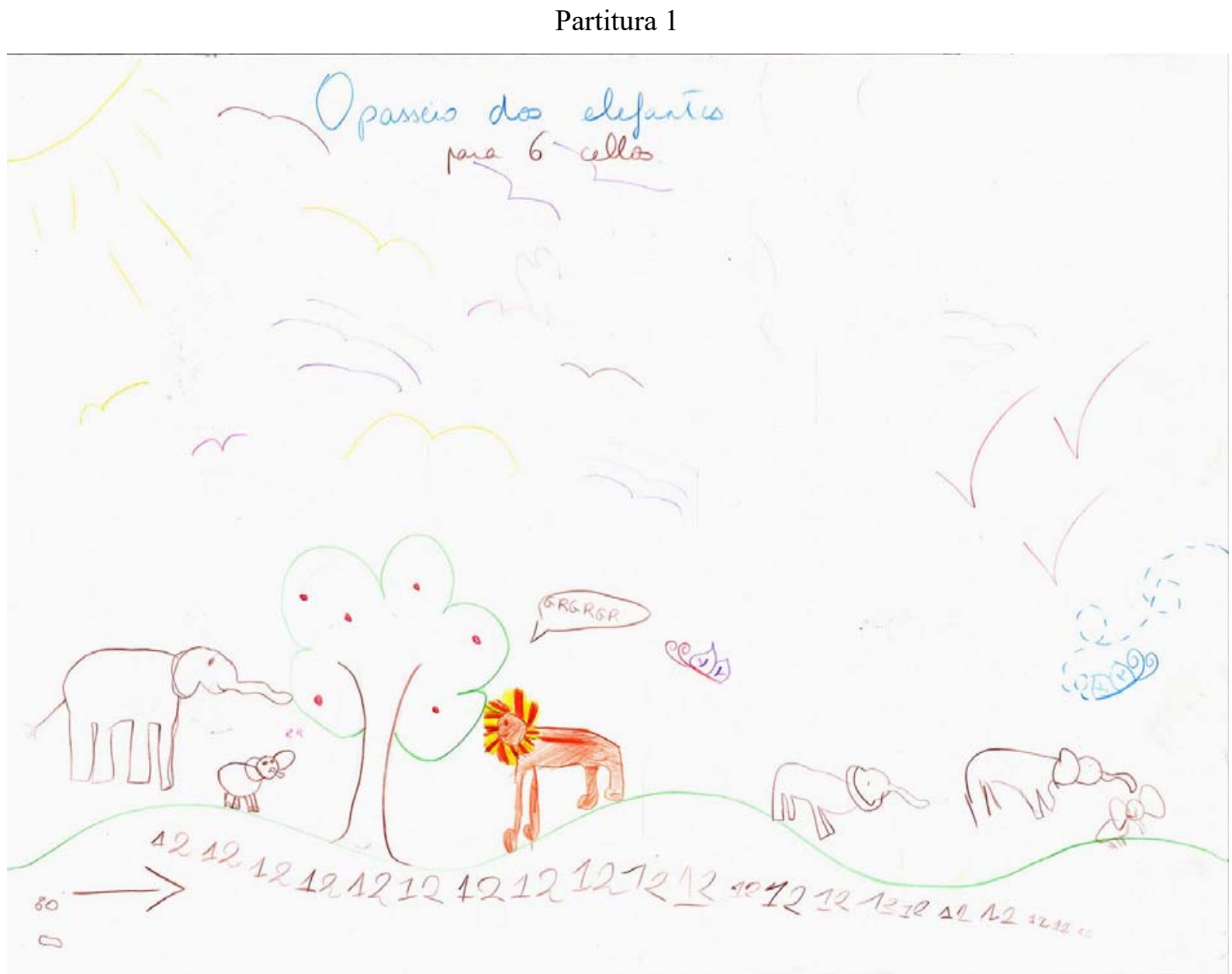

Fonte: material produzido pelos alunos durante a pesquisa de campo. 
Partitura 2

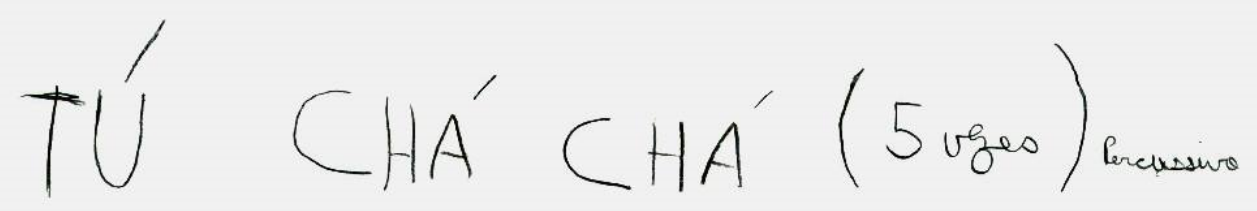
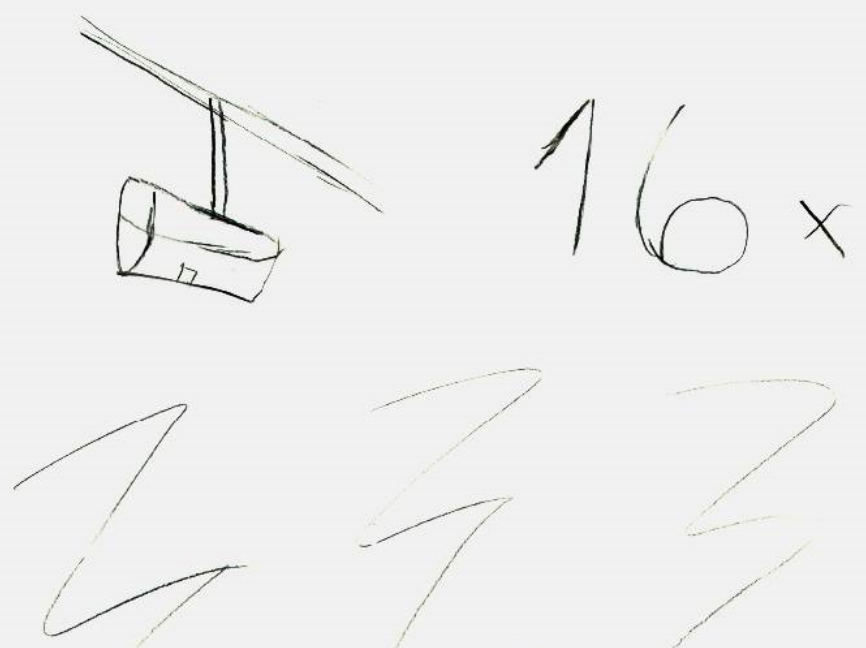

Jow P. P

Seadora

Horisa
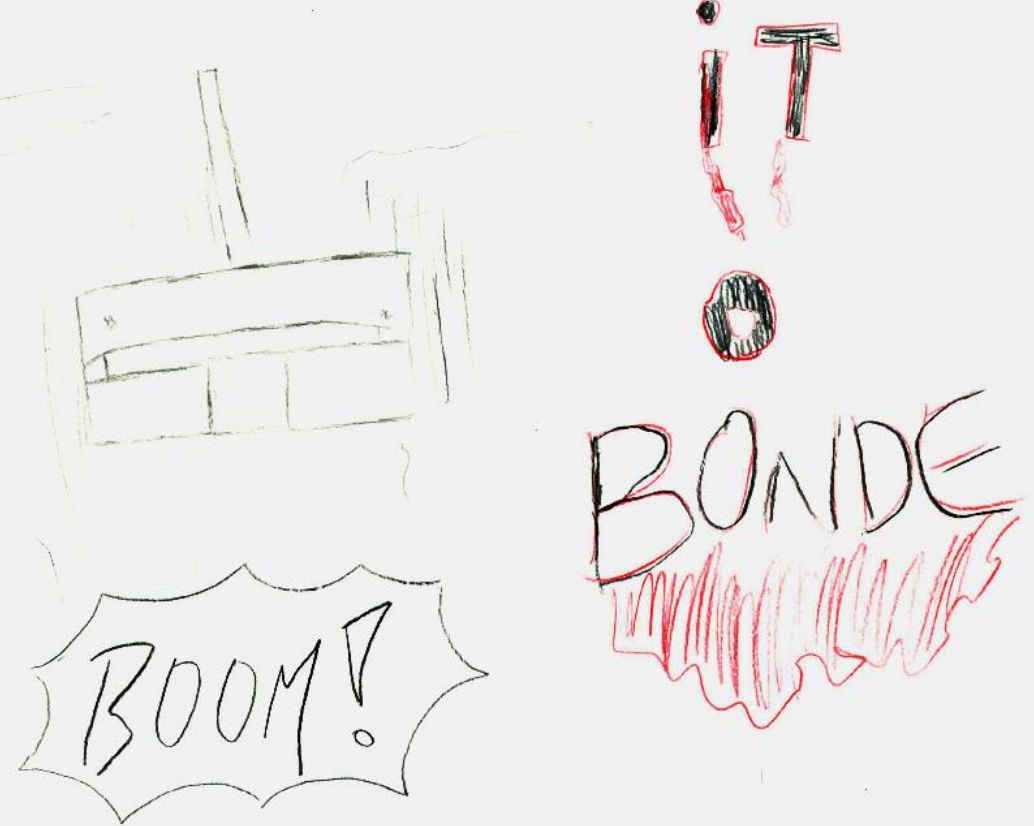

Fonte: material produzido pelos alunos durante a pesquisa de campo. 
Partitura 3

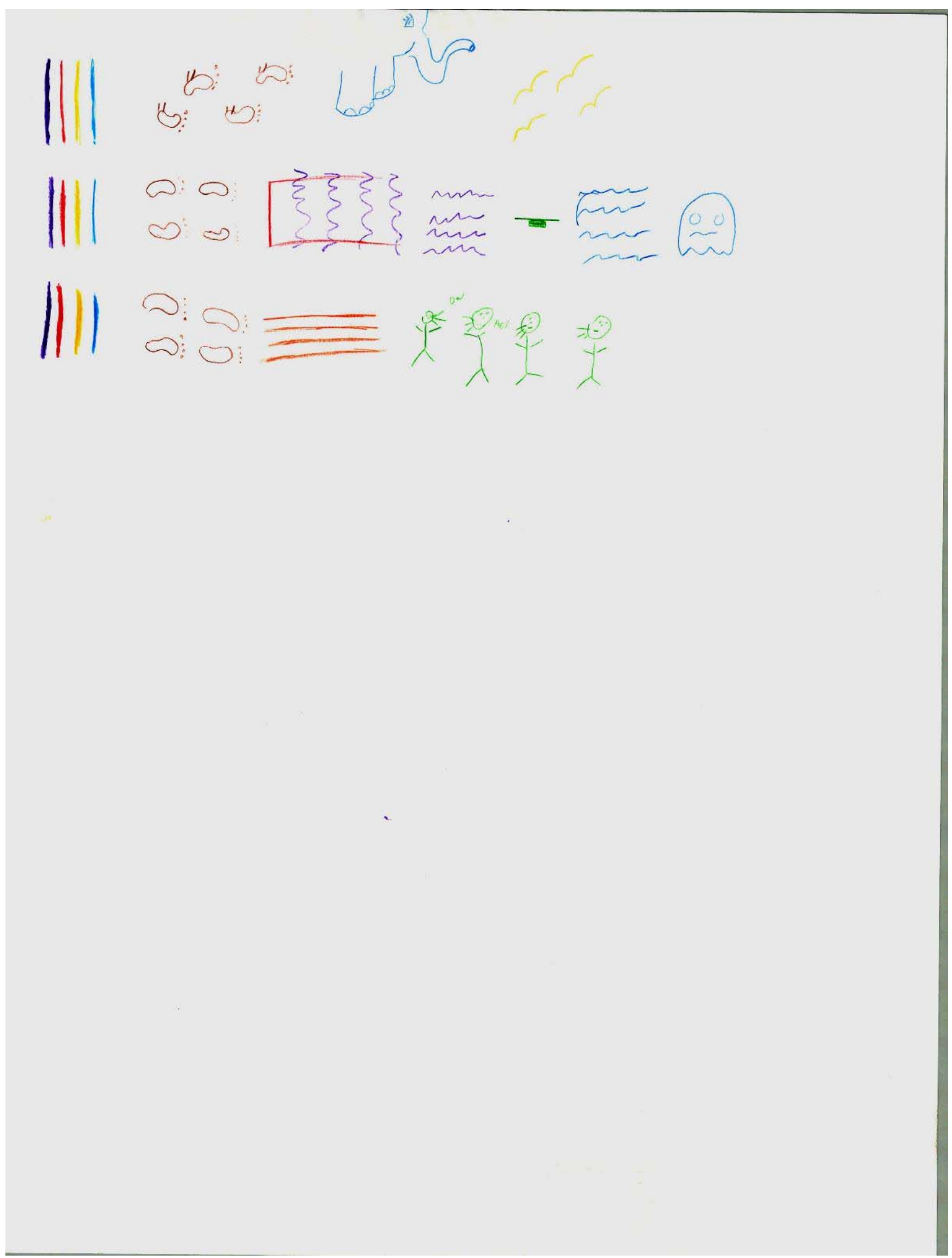

Fonte: material produzido pelos alunos durante a pesquisa de campo. 
Partitura 4

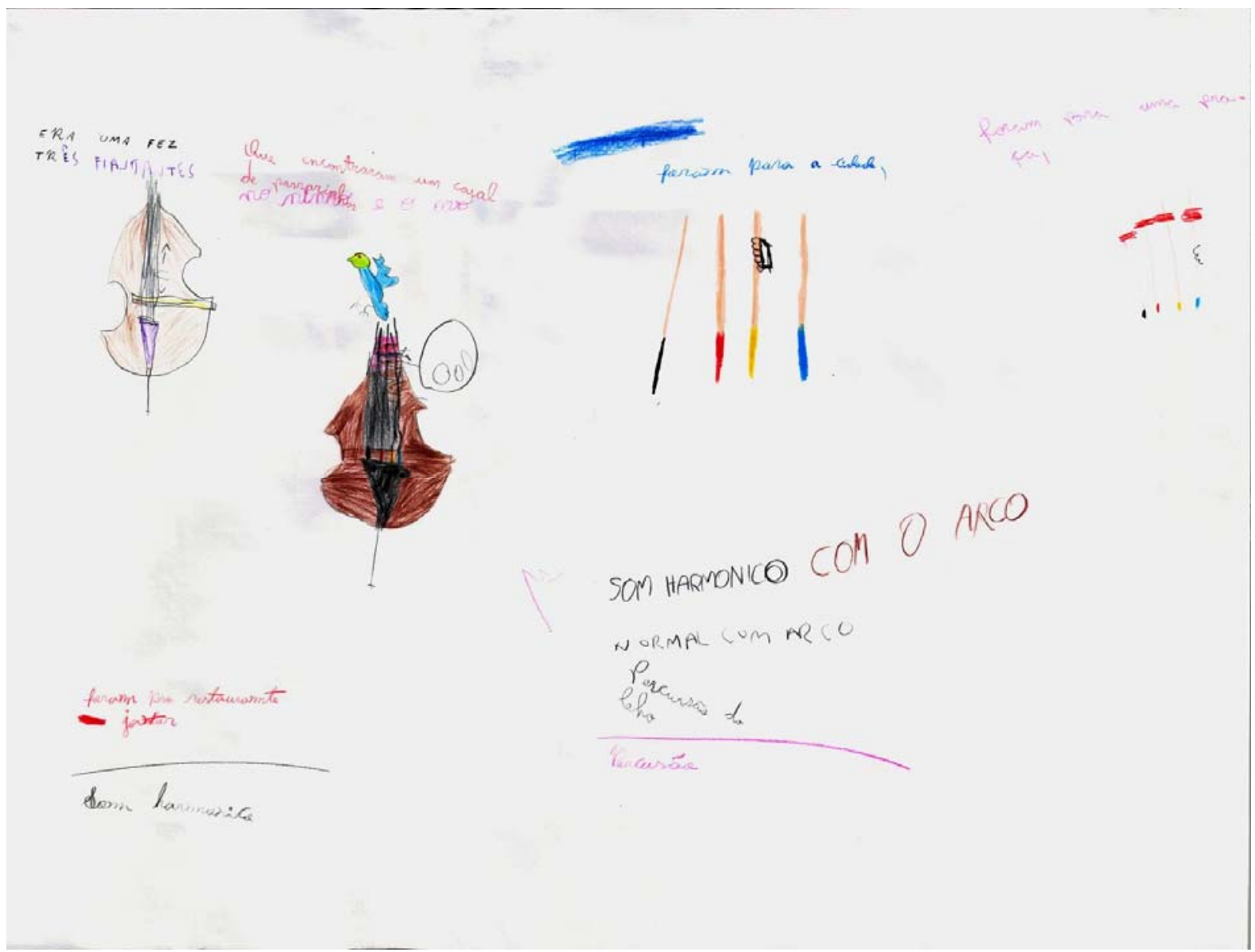

Fonte: material produzido pelos alunos durante a pesquisa de campo. 
Partitura 5

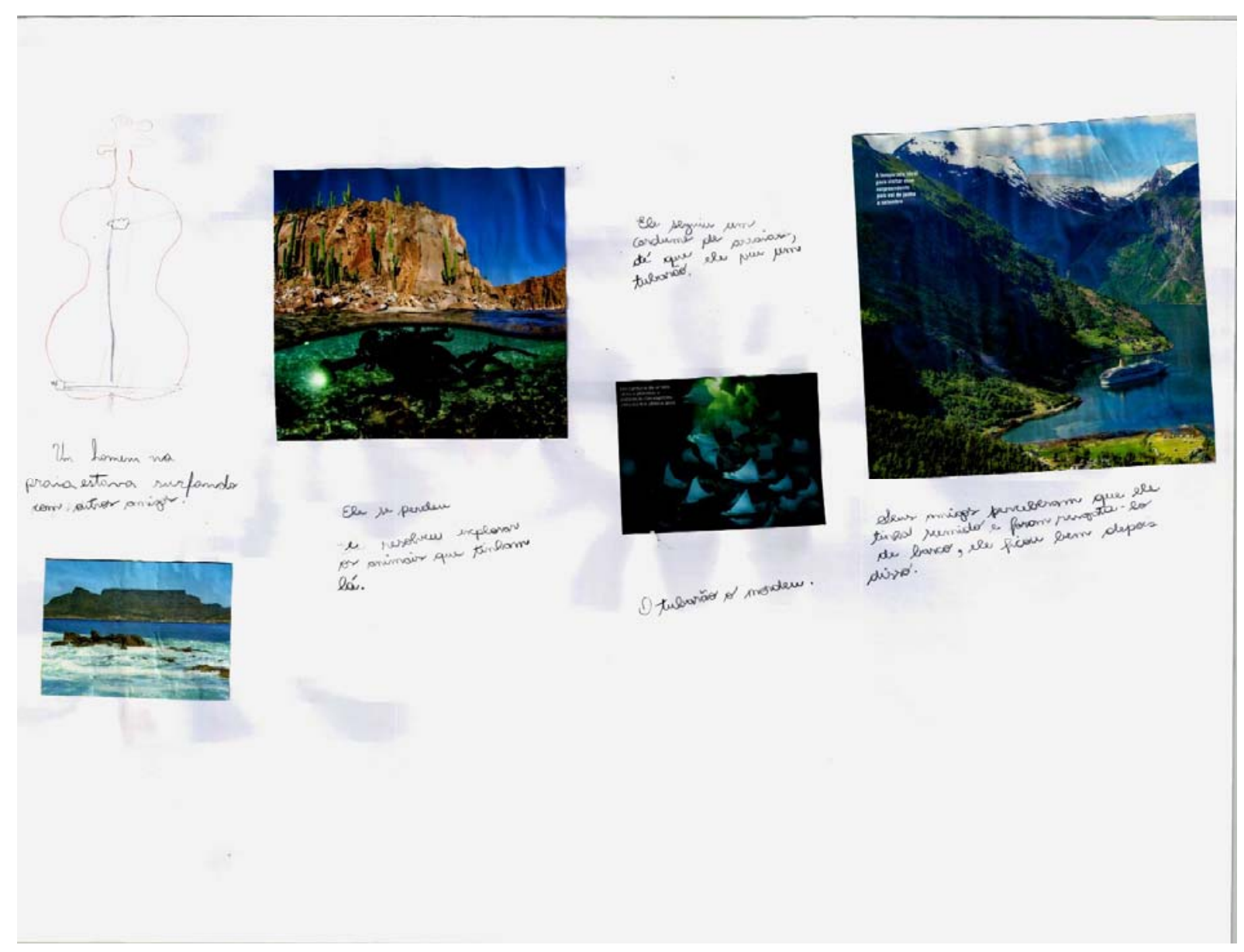

Fonte: material produzido pelos alunos durante a pesquisa de campo. 